Universidad deValladolid

PROGRAMA DE DOCTORADO EN INGENIERÍA QUÍMICA Y AMBIENTAL

TESIS DOCTORAL:

\title{
SIMULATION OF THE FRACTIONATION OF BIOMASS BY HYDROTHERMAL PROCESSES WITH SUB AND SUPERCRITICAL WATER
}

Presentada por Álvaro Cabeza Sánchez para optar al grado de Doctor/a por la Universidad de Valladolid

\author{
Dirigida por: \\ Juan García Serna \\ Francisco Sobrón Grañón \\ María José Cocero Alonso
}



Universidad deValladolid

PROGRAMA DE DOCTORADO EN INGENIERÍA QUÍMICA Y AMBIENTAL

TESIS DOCTORAL:

\title{
SIMULACIÓN DEL FRACCIONAMIENTO DE BIOMASA MEDIANTE PROCESOS HIDROTERMALES CON AGUA SUPERCRÍTICA Y SUBCRÍTICA
}

Presentada por Álvaro Cabeza Sánchez para optar al grado de

Doctor/a por la Universidad de Valladolid

\author{
Dirigida por: \\ Juan García Serna \\ Francisco Sobrón Grañón \\ María José Cocero Alonso
}



Memoria para optar al Grado de Doctor,

con Mención de Doctorado Internacional

presentada por el Ingeniero Químico

\title{
ÁLVARO CABEZA SÁNCHEZ
}

\author{
Siendo los tutores \\ Dr. D. Juan García Serna, \\ Dr. D. Francisco Sobrón Grañón \\ Y \\ Dra. D. María José Cocero Alonso
}

Valladolid, Septiembre del 2018 


\title{
UNIVERSIDAD DE VALLADOLID
}

\section{ESCUELA DE INGENIERÍAS INDUSTRIALES}

\author{
Secretaría
}

La presente tesis doctoral queda registrada en el folio número del correspondiente libro de registro número

Valladolid, a de de 2018

Fdo. El encargado de registro 


\section{Juan García Serna}

Profesor Titular de Universidad (Senior Lecturer)

Departamento de Ingeniería Química y Tecnología del Medio Ambiente Universidad de Valladolid

\section{Francisco Sobrón Grañón}

Profesor Titular de Universidad (Senior Lecturer)

Departamento de Ingeniería Química y Tecnología del Medio Ambiente Universidad de Valladolid

\section{María José Cocero Alonso}

Catedrática (Professor)

Departamento de Ingeniería Química y Tecnología del Medio Ambiente

Universidad de Valladolid

Certifican:

Que el Ingeniero Químico ÁLVARO CABEZA SÁNCHEZ ha realizado en el Departamento de Ingeniería Química y Tecnología del Medio Ambiente de la Universidad de Valladolid, bajo nuestra dirección, el trabajo que, para optar al grado de Doctorado Internacional, presenta con el título "SIMULATION OF THE FRACTIONATION OF BIOMASS BY HYDROTHERMAL PROCESSES WITH SUB AND SUPERCRITICAL WATER", cuyo título en castellano es "SIMULACIÓN DEL FRACCIONAMIENTO DE BIOMASA MEDIANTE PROCESOS HIDROTERMALES CON AGUA SUPERCRÍTICA Y SUBCRÍTICA"

Valladolid, a de de 2018 
Reunido el tribunal que ha de juzgar la tesis doctoral titulada "SIMULATION OF THE FRACTIONATION OF BIOMASS BY HYDROTHERMAL PROCESSES WITH SUB AND SUPERCRITICAL WATER" presentada por el Ingeniero Químico ÁLVARO CABEZA SÁNCHEZ y en cumplimiento con lo establecido en el Real Decreto 1393/2007 de 29 Octubre ha acordado conceder por la calificación de

Valladolid, a de de 2018 
Table of Contents

\section{TABLE OF CONTENTS}



$\begin{array}{ll}\text { Introduction } & 1\end{array}$

Supercritical fluid extraction $\quad 4$

$\begin{array}{lr}\text { Biomass pyrolysis } & 8\end{array}$

Biomass hydrothermal fractionation $\quad 13$

$\begin{array}{ll}\text { Thesis objectives } & 18\end{array}$

$\begin{array}{ll}\text { Thesis methodology } & 19\end{array}$

$\begin{array}{lr}\text { Abstract } & 29\end{array}$

$\begin{array}{ll}\text { Resumen } & 33\end{array}$

Chapter 1: Simulation of the supercritical CO2 extraction from natural matrices in packed bed columns: User-friendly simulator tool using Excel 49

$\begin{array}{ll}\text { Abstract } & 51\end{array}$

Introduction $\quad 52$

Extraction process and available data $\quad 53$

Extraction process

Available data and raw material 54

Extraction theory

Mass transfer during an extraction from a sloid raw material 56

Solubility in SCF

$\begin{array}{ll}\text { Co-solvents } & 57\end{array}$

$\begin{array}{ll}\text { Model } & 58\end{array}$

Resolution $\quad 59$

Results and discussion $\quad 59$

Pressure and temperature effect: solubility changes 59

Particle diameter and flow effect: mass transfer changes 61

Fittings $\quad 63$

Equilibrium constant $\quad 64$

Mass transfer coefficient $\quad 67$

Breaking times $\quad 69$

Simulation of the internal behaviour 71

$\begin{array}{ll}\text { Excel interface considerations } & 73\end{array}$

$\begin{array}{ll}\text { Conclusions } & 73\end{array}$ 
Nomenclature

$\begin{array}{ll}\text { Acknowledgements } & 75\end{array}$

$\begin{array}{ll}\text { References } & 75\end{array}$

List of Tables and figures $\quad 76$

Chapter 2: Autocatalytic kinetic model for thermogravimetric analysis and com-position estimation of biomass and polymeric fractions 79

$\begin{array}{ll}\text { Abstract } & 81\end{array}$

$\begin{array}{ll}\text { Introduction } & \mathbf{8 2}\end{array}$

Materials and methods $\quad 84$

$\begin{array}{ll}\text { Materials } & 84\end{array}$

$\begin{array}{ll}\text { Biomass characterisation } & 85\end{array}$

Sugar content $\quad 85$

Solid analysis. Klason lignin determination and

sugars attached to the solid 85

Experimental set-up and procedure $\quad 86$

Procedure for the analysis of the effect of the composition 86

Procedure for the analysis of the effect of the structure 86

Procedure for the analysis of the effect of the heating rate 87

Procedure for the analysis of the effect of the isothermal conditions 87

$\begin{array}{ll}\text { Mathematical model } & 87\end{array}$

$\begin{array}{ll}\text { Biomass composition } & 87\end{array}$

$\begin{array}{ll}\text { Reaction pathway } & 89\end{array}$

Degradation process $\quad 89$

Reaction mechanism $\quad 89$

The model 90

$\begin{array}{ll}\text { Assumptions } & 90\end{array}$

Mass balances $\quad 90$

$\begin{array}{ll}\text { Kinetics } & 91\end{array}$

Resolution $\quad 93$

$\begin{array}{ll}\text { Results and discussion } & 93\end{array}$ 
Table of Contents

$\begin{array}{ll}\text { Pure samples } & 93\end{array}$

Hemicellulose $\quad 93$

$\begin{array}{ll}\text { Cellulose } & 97\end{array}$

$\begin{array}{ll}\text { Lignin } & 97\end{array}$

$\begin{array}{ll}\text { Complex samples } & 98\end{array}$

$\begin{array}{ll}\text { Grape seeds } & 98\end{array}$

No-extracted and extracted seeds $\quad 98$

Grape skin 99

Hydrolysed samples $\quad 100$

Woody biomass 101

Non-isothermal process $\quad 101$

Isothermal process $\quad 102$

Composition estimation 103

$\begin{array}{ll}\text { Conclusions } & 104\end{array}$

$\begin{array}{ll}\text { Nomenclature } & 108\end{array}$

$\begin{array}{ll}\text { Acknowledgements } & 109\end{array}$

$\begin{array}{ll}\text { References } & 109\end{array}$

List of tables $\quad 111$

$\begin{array}{ll}\text { List of figures } & 111\end{array}$

Chapter 3: Pre-treatment effect on the thermal degradation of a feedstock with low hemicellulose content: Brazilian ginseng $\mathbf{1 1 3}$

$\begin{array}{lr}\text { Abstract } & \mathbf{1 1 5} \\ \text { Introduction } & \mathbf{1 1 6} \\ \text { Materials and Methods } & \mathbf{1 1 9} \\ \text { Results and discussion } & \mathbf{1 2 0} \\ \quad \text { Kinetic model } & \mathbf{1 2 0} \\ \quad \text { Thermograms fitting } & \mathbf{1 2 2} \\ \text { Pre-treatment effect } & \mathbf{1 2 5} \\ \quad \text { Pressurized liquids at } 120 \text { bar } & 125 \\ \quad \text { Supercritical CO } 2 & 128 \\ \text { Ambient pressure water } & 129 \\ \text { Aerial parts } & 130\end{array}$


Abbreviations and symbols

Acknowledgments

References

List of tables and figures

Chapter 4: Two-phase modelling and simulation of the hydrothermal fractiona-tion of holm oak in a packed bed reactor with hot pressurized water

Abstract

Introduction

Experimental

Material and methods

Raw materials

Experimental device

Solid phase characterization. Lignin and sugar content

Liquid phase characterization

Procedure

Effect of the volumetric flow

Effect of the particle diameter

Effect of the operating temperature

Model validation

Modelling

Hydrothermal degradation at subcritical conditions

Biomass solubility

Autohydrolysis

Reaction pathway

Kinetic model

Assumptions

Solid phase balances

Liquid phase balances

Kinetics

Discretisation method

Process simulation 
Influence of operational conditions in the extraction

Fittings

Kinetic parameters

163

Mass transfer parameters

166

Simulated behaviour

168

Conclusions

171

Nomenclature

172

Acknowledgements

175

References

175

List of tables

178

List of figures

178

Chapter 5: Modelling of biomass fractionation in a lab-scale biorefinery: solubilization of hemicellulose and cellulose from holm oak wood using subcritical water

Abstract

Introduction

184

Material and methods

186

Experimental set up

186

Procedure

187

Effect of the temperature

188

Effect of the volumetric flow

189

Model validation

189

Analytical methods

190

Solid characterization

190

Liquid characterization

190

Comprehensive modelling

Fractionation process by hydrothermal processes

at mild temperatures

Reaction pathway

Kinetic model

Mass balances

Solid phase

194

Liquid phase

194

Kinetics 
Table of Contents

Solid phase 194

Liquid phase 195

Kinetic constants 196

Proton reaction order 197

Stoichiometric matrix 197

Solubility 198

$\begin{array}{ll}\text { Resolution } & 198\end{array}$

Results and Discussion $\quad 199$

Effect of volumetric flow and temperature 199

$\begin{array}{ll}\text { Fittings } & 201\end{array}$

Fitted parameters 204

Acceleration factors. Effect of temperature

and volumetric flow 204

Hemicellulose and cellulose composition 205

Simulated behaviour $\quad 205$

Model limitations and other biomasses 211

$\begin{array}{ll}\text { Conclusions } & 211\end{array}$

$\begin{array}{ll}\text { Nomenclature } & 212\end{array}$

$\begin{array}{ll}\text { Acknowledgements } & 214\end{array}$

$\begin{array}{ll}\text { References } & 214\end{array}$

$\begin{array}{ll}\text { Table and Figure Captions } & 217\end{array}$

$\begin{array}{lr}\text { Conclusions } & 219\end{array}$

$\begin{array}{lr}\text { Acknowledgements } & 223\end{array}$

$\begin{array}{ll}\text { References } & 227\end{array}$

Appendixes $\quad 243$

Appendix 1: Other research works developed during the thesis 245

Appendix 2: Further work $\quad 247$

Appendix 3: Curriculum vitae 255 



\section{Introduction}

Fossil fuel economy has been the basis of the economic and social development since it was discovered at the beginning of the $20^{\text {th }}$ century. Nonetheless, this economy is called to be finished in several decades due to the depletion of the crude oil reserves and the pollution problems associated with its use. For these reasons, new sources of energy and chemicals are needed. These sources must be renewable, "green" and abundant enough to overcome the current and future demands. World demand is growing almost continuously since the last century, as population grows. Meeting the demands without changing the paradigm will not be supported and last longer.

Looking back to nature, natural sources and natural products is one of the most realistic options. Thus, research in biomass has been intense in the last years (Clark et al., 2006; Deneyer et al., 2018), a proposal supported by different international institutions, like the European Union or the Organisation for Economic Co-operation and Development (King, 2009; OCDE, 2009; Organisation, 2011). The basic idea is to transform the biomass into biofuels and biochemicals in a biorefinery (Bozell, 2008; Cheng \& Zhu, 2009). A biofuel is every fuel (solid, liquid or gas) obtained from the treatment of biomass (Demirbas, 2010).

Biorefinery can be defined as the place where biomass is transformed by different "green" processes into chemicals, fuels, heat and power. Ideally, a biorefinery could be fed by several kinds of biomasses, which should be completely converted by processes with near zero emissions and wastes. This conversion consists of the fractionation of the biomass components and further conversion similar to a conventional refinery. The main components can be divided in two groups: structural components (hemicellulose, cellulose and lignin) and low molecular weight substances (organic and inorganic). Cellulose and hemicellulose are both polysaccharides of up to 10,000 and 300 monomers, respectively. Cellulose is composed of hexoses, it is mainly linear, and it has high degree of crystallinity. Hemicellulose, in contrast, is amorphous, branched and it is mainly composed of pentoses (although a certain amount of linked hexoses can be present). Concerning lignin, it is an aromatic biopolymer formed by alkyl phenols (Bobleter, 1994; Gollakota et al., 2018; Tekin et al., 2014). Moreover, other compounds, usually known as extractives, can be also present in biomass. These compounds can be organic and inorganic and include proteins, fats, fatty acids, sugars, phenols, terpenes, resin acids and resin (Gollakota et al., 2018; Tekin et al., 2014). 


\section{Introduction}

Regarding the processes for the biomass fractionation (Figure 1), they are: biomass pretreatment (like milling or prelaminar extractions with ionic liquids (Yoo et al., 2017) or supercritical fluids), thermochemical conversion (such as, gasification, pyrolysis or hydrothermal treatments), bioconversion (like fermentation) and product separation (purification steps). However, not always the direct flow is followed. For instance, a raw material could be first pre-treated, followed by a bioconversion process and a thermochemical treatment, being its output fed to the purification step. Among all these steps, this thesis focused the attention on a pre-treatment (supercritical fluid extraction) and two thermochemical conversion processes: biomass pyrolysis and the hydrothermal fractionation of biomass. These three technologies were selected since they just required temperature and a fluid phase to extract or recover added value products from the biomass. For this reason, a brief description of them is done in sections 1.1, 1.2 and 1.3, respectively.

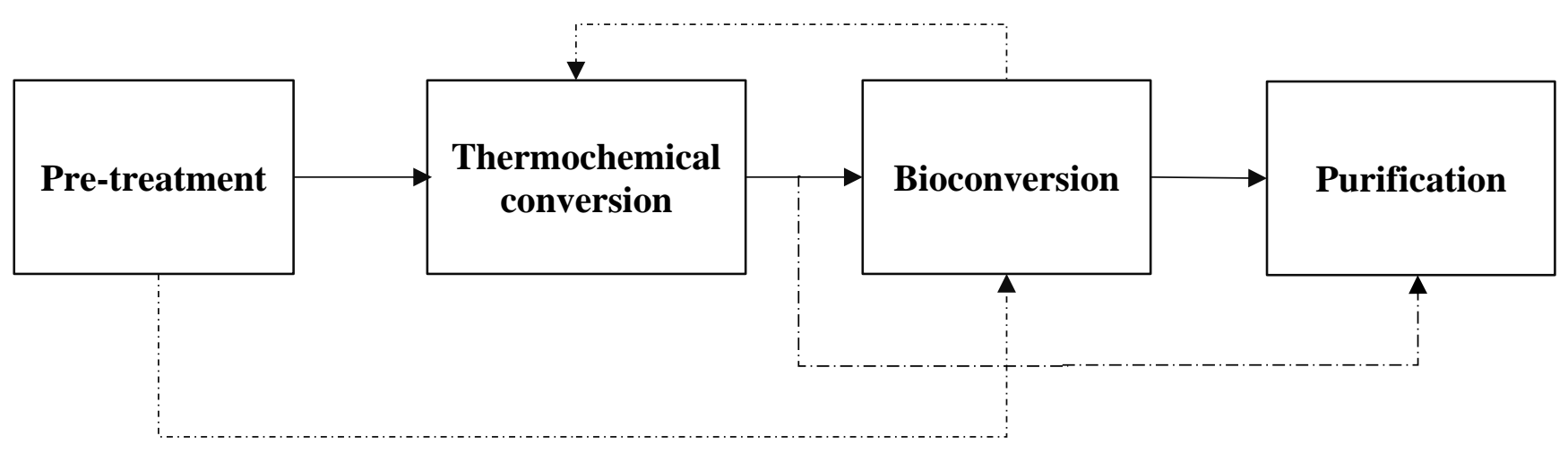

Figure 1. Block diagram of a biorefinery. The dotted lines refer to the cross processes that are available in this kind of systems.

\section{Supercritical fluid extraction}

A supercritical fluid (SCF) is all substance obtained when temperature and pressure are above its critical point and does not condense if pressure is increased further (Figure 2). Supercritical fluids have intermediate properties between gases and liquids (diffusivity, viscosity and density), which make them an excellent solvent for a wide range of compounds (solutes). Moreover, they can be completely removed from the extracts just by an expansion, producing a totally pure product and a gas that can be recycled. The fact that no other process afterwards is required to purify the product involves a low energy consumption and also a higher quality in the product, since thermal degradation is avoided. And, what is more, the properties of the supercritical fluids (including the 


\section{Introduction}

dielectric constant) can be easily tuned by changes in pressure and temperature. So, they are a perfect choice to substitute the conventional solvents. Additionally, they also have quite suitable heat transfer properties which also make them a good option for refrigeration system. Among all of them, water $(\mathrm{SCW})$ and $\mathrm{CO}_{2}\left(\mathrm{scCO}_{2}\right)$ are the most common since they are: non-carcinogenic, nontoxic, non-mutagenic and non-flammable (Henley \& Seader, 1981; Herrero et al., 2010; Knez et al., 2014; Manivannan \& Sawan, 1998; Nahar \& Sarker, 2012). $\mathrm{ScCO}_{2}$ is the most used since it requires relative low pressures $(7.38 \mathrm{MPa})$ and temperatures $\left(31.1{ }^{\circ} \mathrm{C}\right)$ to achieve the supercritical state. However, as it is nonpolar, the extraction of polar compounds would not be possible. For this reason, little amounts (<10\% (Herrero et al., 2010)) of polar co-solvent (like ethanol) are introduced in the $\mathrm{scCO}_{2}$.

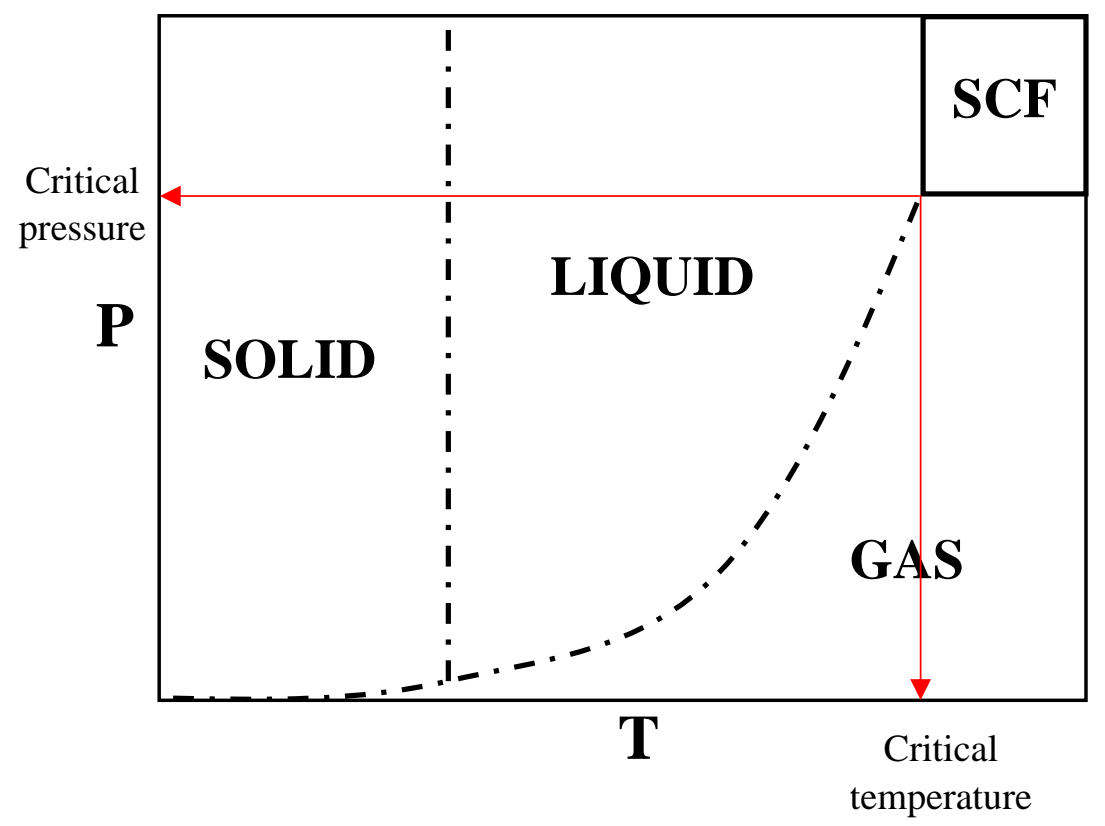

Figure 2. Phase diagram with the solid, liquid, gas and supercritical fluid (SCF) states.

Supercritical fluid extraction (SFE) is the operation where a matrix or liquid is treated by a SCF in order to recover one or more compounds. This process has been already used in industry for the extraction of caffeine, tea, spices, hops and flavour (Herrero et al., 2010; Huang et al., 2012). Other examples, currently under study, are the extraction of bioactive substances from natural sources (e.g. essential oils) or the removal or toxic or unwanted species, like soils cleaning (Herrero et al., 2010; Sunarso \& Ismadji, 2009). However, not only SCFs are used for extraction processes, but also for new material synthesis (such as aerogels), analytical techniques (SCF chromatography), particle formation and product formulation. Similarly, they are also used in industry for many other processes, like jet 


\section{Introduction}

cutting or dry cleaning (Herrero et al., 2010; Knez et al., 2014). A typical configuration of a laboratory SFE plant using $\mathrm{scCO}_{2}$ is displayed in Figure 3. It essentially consists of a tank for the mobile phase, a condenser (to guarantee $\mathrm{CO}_{2}$ liquid conditions), a pump to pressurize the fluid, a heater to reach the desired temperature, the extraction column, an expansion valve and a depressurisation tank, were the product is recovered (Knez et al., 2014).

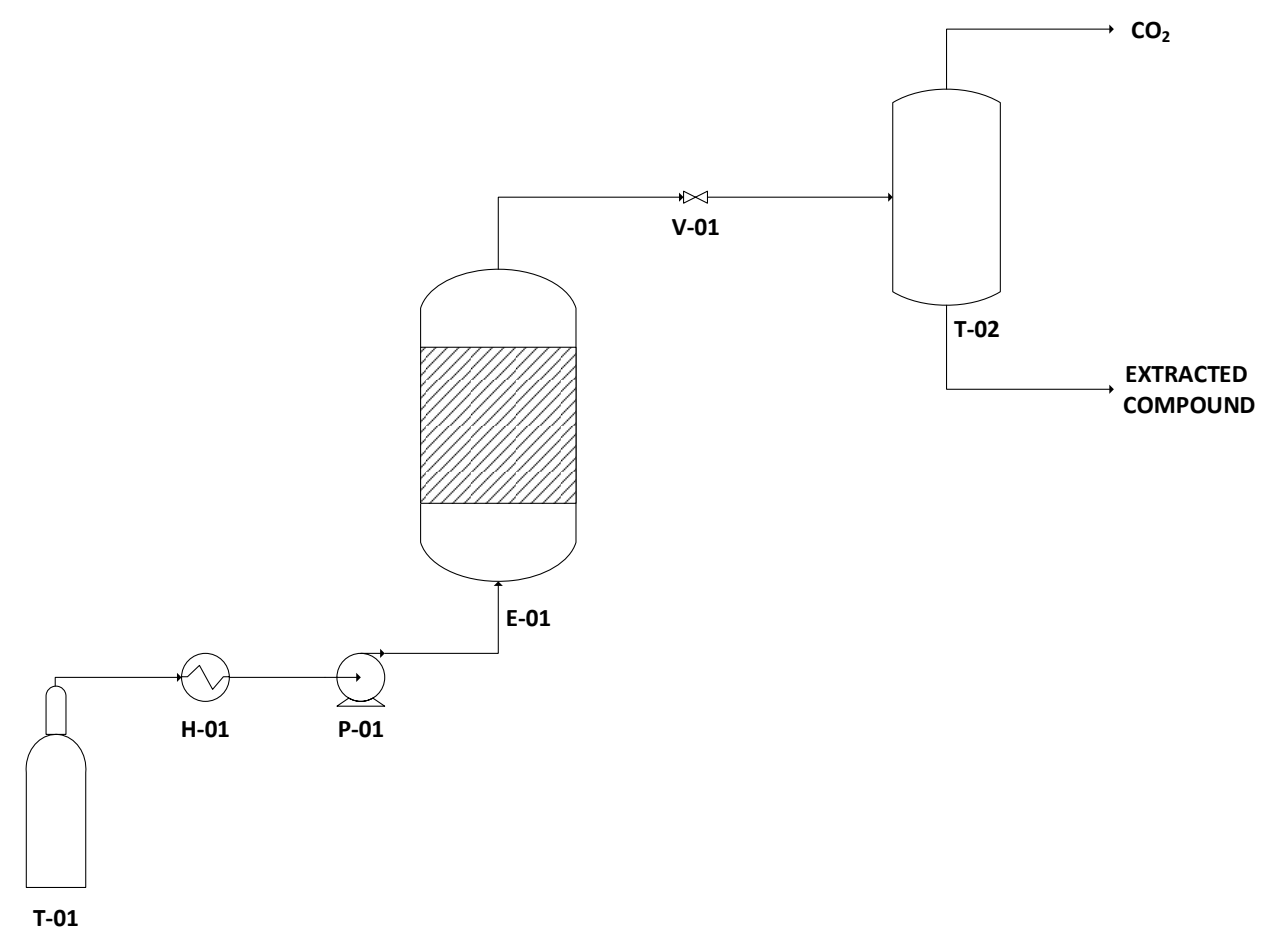

Figure 3. Process flow diagram of a typical SFE process with CO2. T-01: gas bottle, H-01: heat exchanger, P-01: pump, E-01: extraction column, V-01: expansion valve and T-02: depressurisation vessel.

In the first paragraph, it was exposed that SCFs can be tuned in order to modify their physical properties to enhance the extraction of a certain compound. However, the extraction performance not only depends on the solvent properties, but also on the raw material characteristics (particle size, shape, surface area, porosity and the interaction between the matrix and the solute). For instance, high particle sizes would lead to unsuitable internal and external mass transfers, even though the solubility were quite high. The steps involved in the extraction of a compound can be generally divided into: (1) external mass transfer of the SCF from the bulk to the solid, (2) internal diffusion of the SCF, (3) solute dissolution, (4) internal diffusion of the SCF and the solute and (5) external mass transfer of the SCF and the dissolved solute. Furthermore, these steps can be grouped in thermodynamic (number 3) and mass transfer resistances (numbers 1, 2, 4 and 5) (da Silva et al., 2016; Huang et al., 2012; Knez et al., 2014). 


\section{Introduction}

\section{SFE modelling}

SFE modelling is used to understand better the extraction phenomena and be able to predict the behaviour of the process. Many studies have been using different approaches that have been able to successfully simulate a SFE (de Melo et al., 2014; Döker et al., 2010; Sovová, 1994). A good summary of all them can be found in the work of Huang et al (Huang et al., 2012). All of them can be divided into two overall groups: simplified and complex. The first simplified option is the diffusion layer theory (DLT) model. This model assumes that the mass transfer is controlled by the external mass transfer between the solute concentration on the liquid layer in contact with the solid surface and the bulk concentration. In this approach the extraction rate is directly calculated by the first Fick's law. Other option is to assume the SFE as a desorption from the solid to the fluid, simulating it by a mass balance for each compound and phase. The last simple model is the based on the partition coefficient, which assumes that the desorption and the distribution of the solute between the solid and the fluid are extremely rapid and do not affect the yield. The first option inside the complex models is the hot sphere diffusion model. This approach assumes the SFE to be equal to the cooling of hot spheres (at globalised initial temperature) inside a homogenous medium. This model includes the five mass transfer steps (defined in the previous paragraph) involved in a SFE. The following complex model is one of the most extended option for SFE, the Broken and Intact Cells (BIC) model. This proposal assumes that there are two different fractions in the raw material, one where the extraction is much easier to perform (the broken cells) and another fraction where this extraction is more difficult (the intact cells). This idea agrees with the effect of the physical pre-treatments (like milling, grinding or ultrasounds) that the biomass suffers before a SFE. The last model for SFE is the shrinking core model, assuming a decreasing core of solute inside the solid. So, the idea is to define two different internal diffusion steps, one in the exhausted solid fraction and another in the time decreasing core rich in solute. Nonetheless, as these two fractions are time dependant, the model commonly uses an average and globalised concentration for the solid phase. Finally, and just to illustrate the modelling of the SFE of a compound using the 5 mass transfer steps, the diffusive model for a porous spherical particle is shown in Eq. ( 1 ) (SCF mass balance) and Eq. ( 2 ) (solid mass balance). 


$$
\begin{gathered}
\frac{\partial C}{\partial t}=-\frac{u}{L \cdot \varepsilon_{b}} \cdot \frac{\partial C}{\partial z}+\frac{D_{e f f}}{L^{2}} \cdot \frac{\partial^{2} C}{\partial z^{2}}-3 \cdot \frac{k}{R_{p}} \cdot \frac{\left(1-\varepsilon_{b}\right)}{\varepsilon_{b}} \cdot\left(C-C_{P_{r=1}}\right) \\
\frac{\partial C_{P}}{\partial t}+\frac{\left(1-\varepsilon_{P}\right)}{\varepsilon_{P}} \cdot \frac{\partial q}{\partial t}=\frac{D_{P}}{R_{p}^{2}} \cdot\left(\frac{\partial^{2} C_{P}}{\partial r^{2}}+\frac{2}{r} \cdot \frac{\partial C_{P}}{\partial r}\right)
\end{gathered}
$$

Where $C$ is the solute concentration in the fluid phase, $C_{P}$ is the solute concentration in the pores, $C_{P_{r=1}}$ is de concentration of the pore at the particle surface, $D_{\text {eff }}$ is the effective axial diffusivity of the liquid, $k$ is the mass transfer coefficient, $L$ is the column length, $t$ is the operating time, $\varepsilon_{b}$ is the bed porosity, $\varepsilon_{P}$ is the particle porosity, $D_{P}$ is the diffusivity in the pores, $q$ is the solute concentration in the solid (related with $C_{P}$ by an adsorption isotherm), $R_{p}$ is the radius of the particle, $r$ is the radial coordinate and $z$ is the axial coordinate.

From the analysis of all the described models, it can be checked that they require a good knowledge about the mass transfer fundamental behind. And, what is more, their resolution also implies complex sets of mathematical equations. Thus, there needs to be a user-friendly tool that could simulate the SFE, also using an easy understanding model.

\section{Biomass pyrolysis}

The pyrolytic treatment of biomass is one of the most assessed processes for the thermochemical conversion of biomass into fuels and chemicals. The specific products obtained during the pyrolysis of biomass are: bio-oil or tar (mixture of several organic compounds, like acetic acid or furfural (Mullen \& Boateng, 2008)), charcoal or biochar (a solid residue rich in carbon) and pyrolytic gas (a mixture of several gases, like hydrogen and carbon monoxide). This process has been so studied since the fractionation just needs to heat (usually with a hot inert gas) the raw material to produce the fractionation. Nevertheless, biomass pyrolysis is a quite complex process as each individual component does not have the same behaviour and several reactions are involved. Additionally, the interaction between these components and the operational conditions can also modify the mechanisms and reaction rates (Kan et al., 2016). The thermal degradation of biomass during a pyrolysis involves several reactions in parallel and series: dehydration, depolymerisation, isomerization, aromatisation, decarboxylation, and charring (Anca-Couce, 2016; Elyounssi et al., 2012; Kan et al., 2016; Shafizadeh, 1982; Sharma et al., 2015; Van de Velden et al., 2010). 


\section{Introduction}

The pyrolytic process of biomass can be conceptualised in three overall stages: initial evaporation of liquids (water and oils), primary decomposition and secondary reactions (oil cracking and repolymerisation). The fractionation of biomass is mainly done during the primary decomposition $\left(200-400^{\circ} \mathrm{C}\right)$. All these reactions were considered to develop one of the most extended option for a pyrolysis reaction path way: the Waterloo's mechanism (Figure 4). A mechanism that was initially developed from the study of the cellulose decomposition.

The different biopolymers exhibit different behaviour under temperature and time. Thus, hemicellulose starts to break between 250 and $380{ }^{\circ} \mathrm{C}$, cellulose decomposition takes place between 300 and $400{ }^{\circ} \mathrm{C}$ and lignin exhibits a broader temperature interval from 200 up to $550{ }^{\circ} \mathrm{C}$.

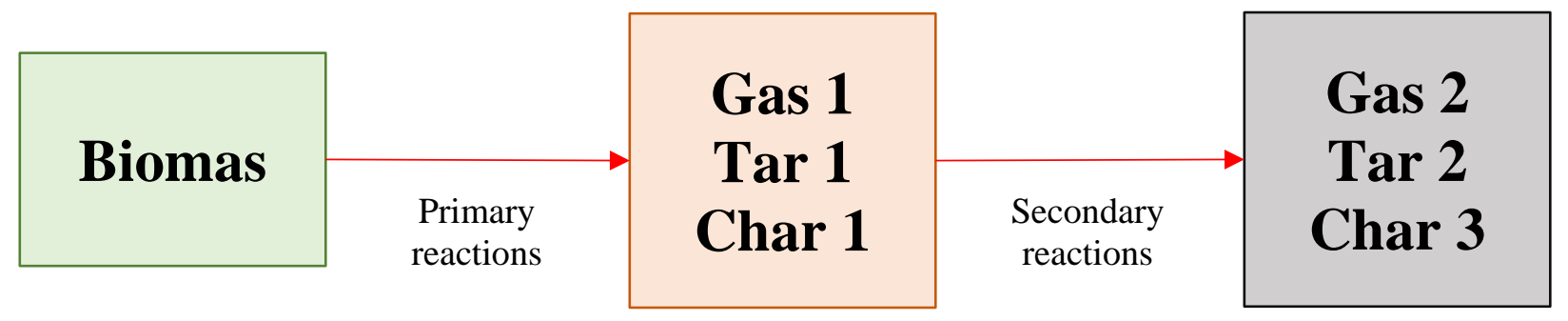

Figure 4. Waterloo's mechanism (Jahirul et al., 2012; Radlein et al., 1991; Van de Velden et al., 2010)

Due to this complexity, pyrolysis performance is affected by a wide range of variables: the solid and gas residence time, the temperature range, the heating rate, the final temperature, the sample size and the atmosphere type (inert or oxidant). The residence time is related to the secondary reactions and, the lower it is, the more bio-oil is produced. The operating temperature and final temperature promote different reactions and products. When the pyrolysis is done below $400-550{ }^{\circ} \mathrm{C}$, bio-oil production is larger. When temperature rises above $600{ }^{\circ} \mathrm{C}$, char and bio-oil are degraded into gases due to the secondary cracking reactions. The heating rate is one of the most crucial factors, being gases and bio-oil promoted when fast heating speeds are used. In relation to the sample size, it is tuned to avoid mass and energy transfer limitations using small particles. Finally, the use of an oxidant atmosphere involves combustion reactions to the inert atmosphere mechanism, reducing char production. Furthermore, there are other two variables that can affect the process: the biomass type and the pre-treatments performed (Arregi et al., 2018; Das \& Sarmah, 2015; Jahirul et al., 2012; Kabir \& Hameed, 2017; Kan et al., 2016; Oudenhoven et al., 2016; Ru et al., 2015; Widjaya et al., 2018). For instance, biomasses 


\section{Introduction}

with higher initial amounts of hemicellulose and cellulose tend to produce more bio-oil, while those with more lignin promotes the production of char. Although lignin also affects the properties of the bio-oil, increasing its viscosity and the average molecular weight of the products. The extractives (the low molecular weight compounds that can be recovered by a conventional solid liquid extraction) and inert content can also modify the yield of each product, promoting the bio-oil production for the former. Inert compounds, often socalled ashes (potassium, calcium and sodium are the most common) can behave as a catalyst, and depending on their role, the product distribution can be moved to one or another, usually promoting char formation. Regarding the pre-treatments, the idea is to disrupt the sample structure to enhance the pyrolysis of the material. This modification can be done physically (like milling), thermally (such as steam explosion or liquid hot water pre-treatment), chemically (e.g. acid hydrolysis), biologically (like and enzymatic hydrolysis) and with any combination of them. The most common is the milling of the sample to improve the mass and energy transfer in the solid, avoiding diffusional issues and temperatures profiles as it was previously exposed. Moreover, three different kinds of pyrolysis can be defined depending on the value of the operational variables: slow, fast and flash (Jahirul et al., 2012; Ranzi et al., 2008; van der Stelt et al., 2011). Slow pyrolysis takes place when the residence time, the heating rate and temperature range are between $450-550 \mathrm{~s}, 0.1-1.0 \mathrm{~K} / \mathrm{s}$ and $280-680^{\circ} \mathrm{C}$, respectively. These conditions promote char production (yield around 35\%), although gases (35\%) and liquids (30\%) are also produced. Fast pyrolysis involves quite lower residence time (0.5-10 s), far higher heating rates $(10-200 \mathrm{~K} / \mathrm{s})$ and temperatures up to $980{ }^{\circ} \mathrm{C}$, which promotes bi-oil production (50\%). Finally, flash pyrolysis involves residence times lower than $0.5 \mathrm{~s}$, heating rates higher than $1,000 \mathrm{~K} / \mathrm{s}$ and temperatures until $1,030{ }^{\circ} \mathrm{C}$, increasing the liquid yield up to $75 \%$.

On the other hand, the kinetic study of the thermal behaviour of a substance has been widely done using thermogravimetric analysis (TGA) (Chen et al., 2011b; Lv et al., 2010; Williams \& Besler, 1996). This analysis has been generally used due to its simplicity: it only consists of the recording of the mass change of a sample (typically $10 \mathrm{mg}$ ) when it is treated by a heating profile. This recording is done by an analytical balance where the initial biomass sample is allocated. The representation of the mass change versus the operating time or temperature is known as the thermogram. Due to the characteristics of the heating (between $1 \mathrm{~K} / \mathrm{min}$ and $20 \mathrm{~K} / \mathrm{min}$ and temperatures up to around $700{ }^{\circ} \mathrm{C}$ ) it can 


\section{Introduction}

be considered a slow pyrolysis. This analysis is generally done under non-isothermal conditions because some mass would be lost during the initial heating to reach the desired temperature in the isothermal case. However, this analysis just provides an overall information about the process, so it can be only used to develop global models for the three compounds produced (tar, char and gases) or for the biomass as a whole. For this reason, when more specific information is required, more complex techniques (like TGA coupled with mass spectrometry or FTIR) are required (Wang et al., 2017). Despite this, a huge number of studies based on TGA data (the thermogram) can be found in literature (Biney et al., 2015; Cabeza et al., 2015; Capart et al., 2004; Chen et al., 2011a; Cheng et al., 2012; Daouk et al., 2015; Hu et al., 2016; Kastanaki et al., 2002; Lv et al., 2010; Mangut et al., 2006; Ogawa et al., 2014; Scott et al., 2006; Seo et al., 2010; Serapiglia et al., 2009; Serapiglia et al., 2008; Sharma et al., 2014; Slopiecka et al., 2012; Völker \& Rieckmann, 2002; Williams \& Besler, 1996). Moreover, there are several available kinetics for the modelling of these data, being remarkable the first order (Kastanaki et al., 2002; S. Völker, 2002; Slopiecka et al., 2012; Zabaniotou et al., 2008), autocatalytic (Capart et al., 2004), potential (Mangut et al., 2006) and distributed activation energy model (Cai et al., 2014) options. There are many more possibilities, like a Frazer-Suzuki deconvolution or a diffusional model (Hu et al., 2016), but these are less extended. In general, all of them can be used to reproduce or fit the pyrolysis of a wide range of biomasses, from pure cellulose up to real lignocellulosic biomasses. All these models were able to reproduce the behaviour of biomass during a TGA. However, they need to have good mass transfer and reaction fundamentals. Which is not a knowledge shared by all the potential users of this technology. For this reason, a friendly user tool would be required to make easier the analysis of the results obtained rom a TGA. Additionally, this tool should include a model that could take into account the effect of the structure and composition on the thermal degradation of the sample. 


\section{Introduction}

\section{Assumptions of the models}

Furthermore, there are also several assumptions that are common in all of them: (1) cellulose, hemicellulose and lignin degrade independently, (2) the reaction order is one for each compound and (3) there is no internal diffusion or temperature profiles in the solid due to their low size. Thus, the common idea for the reaction path way would like the showed in Figure 5-a. However, a much more simplified version is also widely used, where all the process is simulated by a direct reaction (Figure 5-b).

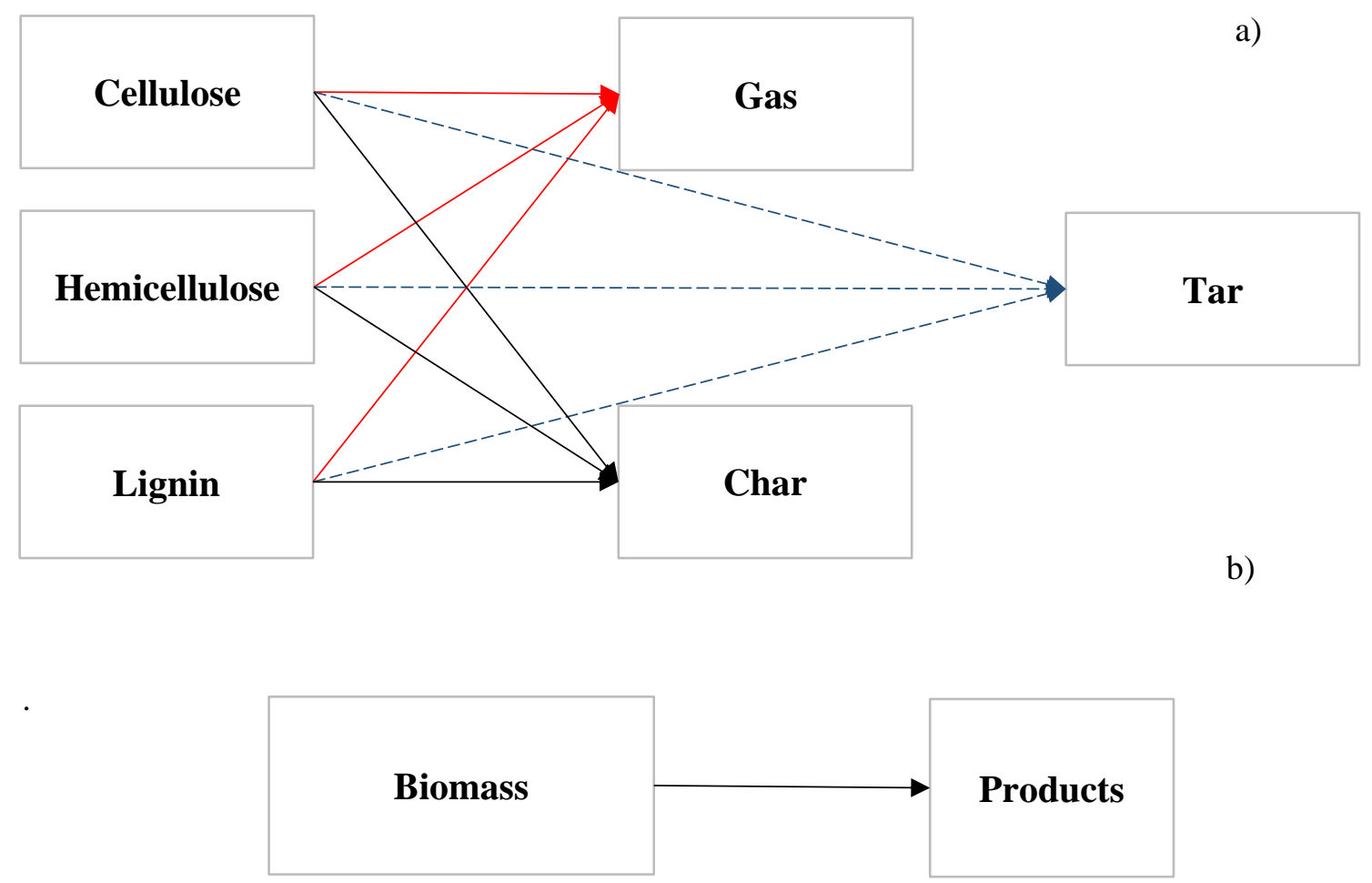

Figure 5. Typical reaction path way for biomass pyrolysis during a TGA including the main compounds (a) and the simplified version (b). Note that the reaction for tar production are as dotted lines. This was done because this reaction is generally not considered since its yield at the operational conditions is quite low.

Regarding the models, the set of mathematical equations, they are essentially obtained applying a non-stationary mas balance for each compound in the sample (Eq. ( 3 ) ).

$$
\frac{d m_{j}}{d t}=r_{j}=\sum_{i=1}^{N_{r}} g_{i j} \cdot r_{i}
$$

Where $m_{j}$ is the mass fraction of the compound " $\mathrm{j}$ ", $r_{j}$ is the reaction rate for the compound " $\mathrm{j}$ ", " $i$ " is the reaction rate number, $N_{r}$ is the total number of reactions, $g_{i j}$ is 


\section{Introduction}

the stochiometric coefficient for the compound " $\mathrm{j}$ " of the reaction number " $\mathrm{i}$ ", $t$ is the operating time and $r_{i}$ is the reaction rate number " $\mathrm{i}$ ". The absolute value for all the stochiometric coefficient commonly is 1 (since these mass balances are done in mass basis). The reaction rate $\left(r_{i}\right)$ is assumed to be the Arrhenius' kinetic constant multiplied by one of the concentration functions defined above. Thereby, for the most extended case, the first order kinetics, Eq. ( 3 ) would be transformed into Eq. ( 4 ).

$$
\frac{d m_{j}}{d t}=r_{j}=\sum_{i=1}^{N_{r}} g_{i j} \cdot k_{i} \cdot m_{j}=\sum_{i=1}^{N_{r}} g_{i j} \cdot k_{0_{i}} \cdot e^{-\frac{E a_{i}}{R \cdot T}} \cdot m_{j}
$$

Where $k_{i}$ is the Arrhenius' kinetic constant, $k_{0_{i}}$ is the pre-exponential factor of the kinetic constant and $E a_{i}$ is the activation energy. Once the model is defined, the following step is to fit the obtained thermogram by minimizing the error between the simulated and the experimental thermograms, giving the kinetic parameters as a result. For the case of the first order kinetic, they would just be the pre-exponential factor and the activation energy. Some reference values for the activation energy of the degradation of pure cellulose, real biomasses, hemicellulose and lignin degradation are: 100-300 kJ/mol (Chen \& Kuo, 2011; Kastanaki et al., 2002; Völker \& Rieckmann, 2002), 11-300 kJ/mol (Slopiecka et al., 2012; Zabaniotou et al., 2008), 90-110 kJ/mol (Chen \& Kuo, 2011; Kastanaki et al., 2002) and 31-40 kJ/mol (Chen \& Kuo, 2011; Kastanaki et al., 2002), respectively. The low value of the lignin activation energy agrees with the fact that it starts to degrade at relative low temperatures $\left(200^{\circ} \mathrm{C}\right)$. However, as it is also composed of really strong fractions, its pre-exponential is up to thirteen orders of magnitude lower. On the whole, these values change with the sample studied and the operational conditions, but what seems to be constant is that cellulose activation energies are always higher than hemicellulose and lignin activation energies (Anca-Couce, 2016). This is easily understandable by just looking at the temperature degradation windows of these compounds, as explained before, i.e. hemicellulose $\left(250-380{ }^{\circ} \mathrm{C}\right)$, cellulose $\left(300-400{ }^{\circ} \mathrm{C}\right)$ and lignin $\left(200-550^{\circ} \mathrm{C}\right)$.

\section{Biomass hydrothermal fractionation}

Biomass hydrothermal fractionation (HTF) is a specific kind of the hydrothermal liquefaction of biomass (HTL). Like pyrolysis, HTL is one of most extended options for the upgrading of biomass. However, it has several advantages over pyrolysis, like the fact 


\section{Introduction}

that raw material drying is not necessary, the fluid (usually water) enhances the fractionation working as a catalyst (protons) and the products obtained resemble the original in the biomass closer (are less degraded). On the other hand, HTL also has a really important drawback, the operational pressure, which can easily reach up to $20 \mathrm{MPa}$. The HTL looks for the conversion of biomass into a biocrude in a highly reactive environment (high temperatures and pressures). The reactions involved in this conversion are mainly decomposition and repolymerisation, which produce a solid residue, gas, aqueous dissolved chemicals and the biocrude. High pressure and temperature are used since they promote the solubility of the hydrocarbons (due to the decrease of the solvent dielectric constant and density) and also enhance the acid-base catalysed reaction due to the changes in the polarity (Dimitriadis \& Bezergianni, 2017; Gollakota et al., 2018; Tekin et al., 2014). This process has been successfully used to produce biocrude from different biomasses, like woody biomass (yields between 17 and 68\%), sludges (yields around 15\%), plastics (yields from $2 \%$ to $95 \%$ ) or agricultural wastes (yields between 21 and 36\%)(Dimitriadis \& Bezergianni, 2017).

Regarding the operational variables in HTL, temperature, which usually ranges from 200 to $500{ }^{\circ} \mathrm{C}$, is one of the most important. In general, a maximum in the biocrude yield is observed when temperature is raised, which is explained by the competition of hydrolysis (oligomers and sugars) and recombination reactions (mainly repolymerisation, condensation and gas cracking). At low temperatures, hydrolysis is the most promoted process, increasing the yield at the same time that temperature is elevated. However, when temperature is higher than $300-400{ }^{\circ} \mathrm{C}$ (the specific value depends on the initial biomass) (Dimitriadis \& Bezergianni, 2017; Tekin et al., 2014), recombination reactions start to take advantage, producing a new solid (hydrochar) and decreasing the yields of the biopolymers and sugars.

A simplified reaction path way can be seen in Figure 6-a. From an overall point of view, the following events can be defined: (1) the water-soluble fraction of the biomass removal at $100{ }^{\circ} \mathrm{C}$, (2) the hydrolysis reactions at $150{ }^{\circ} \mathrm{C}$ (decomposing cellulose and hemicellulose into their monomers), (3) the biomass transformation into a slurry at 200 ${ }^{\circ} \mathrm{C}$ and (4) the conversion of this slurry into an oil around $300{ }^{\circ} \mathrm{C}$ (Tekin et al., 2014). Other key factor is the possible usage of a catalyst (usually a mineral acid, e.g. sulphuric acid), being its general role the reduction of the recombination reactions, increasing the liquid yield and reducing the production of hydrochar. 


\section{Introduction}

Concerning residence time, its effect is, in principle, similar to the temperature: it promotes the yield up to reach a maximum. However, its role depends a lot on the other variables and the initial biomass, so it cannot be easily predicted.

The kind of solvent also plays an essential part on HTL and, although water is the most extended option, organic solvents (like methanol or ethanol) has been demonstrated to be quite acceptable options (they can reach yields twice higher than the water for certain biomasses). Moreover, a combination of water and organic acid can highly promote the yield too (up to 65\%). Nonetheless, the best choice of solvent extremely depends on the biomass to be treated and the targeted products.

Finally, the solid-liquid ratio is also a crucial parameter since if it decreases, the yield can heavily grow. Nevertheless, a high content of liquid (water) involves a huge economic effort to purify and concentrate the final product (Dimitriadis \& Bezergianni, 2017). It is common to use water/solid ratios of between 20/1 to 10/1 (Gallina et al., 2018).

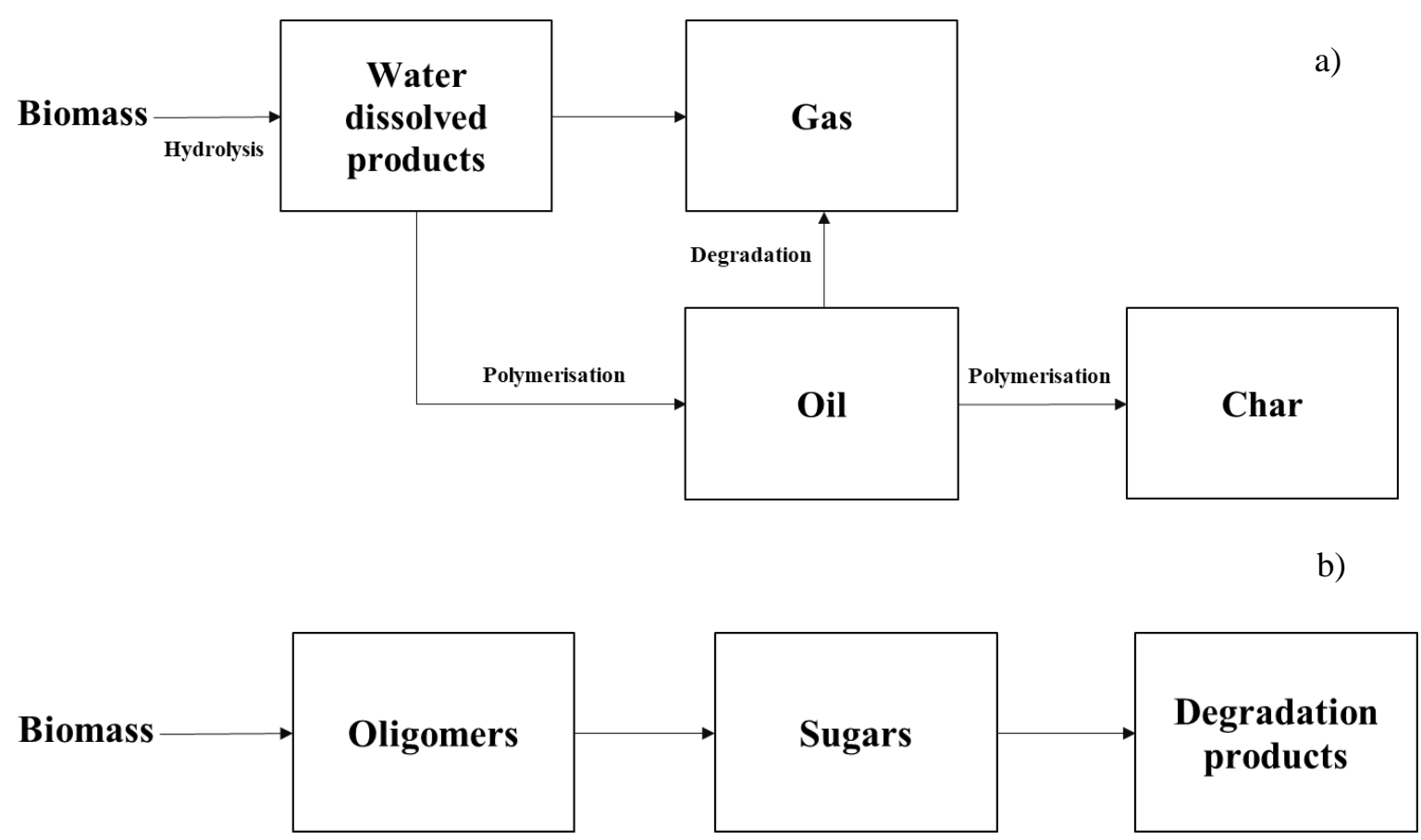

Figure 6. Typical reaction path way for biomass HTL (a) and HTF (b).

On the other hand, HTF is just focused on the extraction of the main compounds of biomass (hemicellulose, cellulose and lignin), avoiding the biocrude formation. The idea is to treat the biomass with hot pressurized water at different temperatures (subcritical or supercritical), obtaining a liquid product with the extracted compound and a solid residue with the other compounds to be recovered (Figure 7). Hemicellulose can be recovered at 


\section{Introduction}

temperatures from 150 to $210^{\circ} \mathrm{C}$, cellulose from 240 to $400{ }^{\circ} \mathrm{C}$ and lignin between 300 and $400{ }^{\circ} \mathrm{C}$ (Cantero et al., 2013; Cocero et al., 2018; Garrote et al., 2002; M. Sefik Tunc, 2008; Moniz et al., 2013; Parajó et al., 2004; Rissanen et al., 2014; Zakaria et al., 2015). However, HTF is usually focused on the extraction of the holocellulosic fraction (hemicellulose and cellulose) and mainly in hemicellulose since the high temperatures required to extract cellulose and lignin implies a huge degradation. In addition, and similarly to the conventional HTL, the quality of the product (molecular weight and degradation degree), also depends on the residence time, temperature, the catalyst and the initial kind of biomass. For this reason, for lignin and cellulose fractionation without degradation, supercritical fluids and an extremely low residence times are mandatory (Cocero et al., 2018).

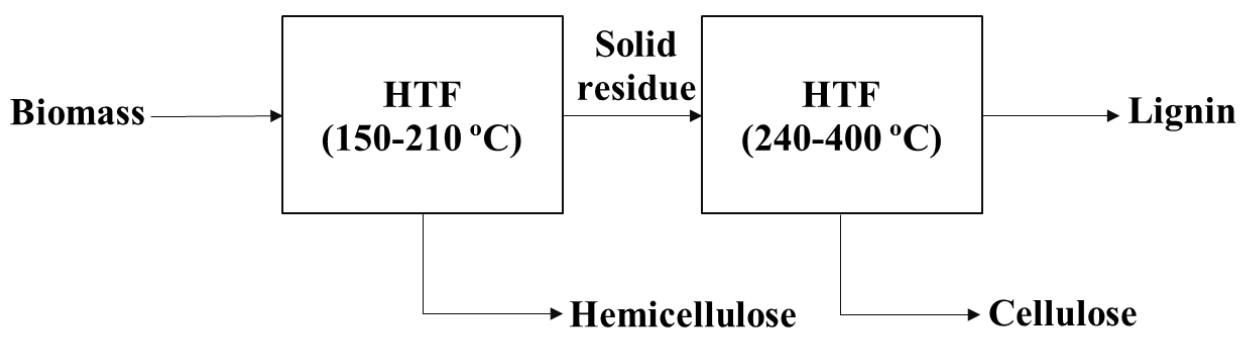

Figure 7. The concept of biomass HTF.

The reactions involved in the HTF equivalent to HTL (hydrolysis and re-polymerisation). However, when hemicellulose (or even cellulose in some cases) is the target compound, the hydrolysis reactions are more important due to the mild conditions that inhibit the repolymerisation (temperature below $300{ }^{\circ} \mathrm{C}$ ). Additionally, the gas production can be also assumed as negligible. So, the overall reaction path way would be like Figure 6-b, where biomass is assumed to decompose into decreasing molecular weight oligomers. Oligomers that can also break into sugars that continued degrading into several degradation products (aldehydes, ketones, furfurals or organic acids).

\section{Modelling the HTF}

The mathematical model is obtained applying transient mass balances to each compound defined in the proposed reaction path way (Charles et al., 2004; Lin et al., 2015; Mohan et al., 2015; Piqueras et al., 2017; Pronyk \& Mazza, 2010; Rivas et al., 2014; Rogalinski et al., 2008; Sasaki et al., 2002; Zhu et al., 2014). However, they do not give an utterly 


\section{Introduction}

realistic view of the whole process since the whole physical phenomenology is not considered.

The models usually consider the following assumptions: (1) series-parallel and (2) irreversible reactions for each main compound (hemicellulose, cellulose and lining), (3) first order kinetics, (4) isothermal conditions and (5) ideal flow regime (plug flow for continuous and semi-continuous reactors or perfect mixture for batch type). For the case of semi-continuous reactor, it is also usual to accept globalised properties for the solid phase. Other common assumption is to consider the mass transfer so high that it can be neglected, developing mono-phasic models. The model for the hydrolysis of biomass in a batch reactor taking into account these assumptions can be seen in Eq. ( 5 ). Additionally, more complex options have been also considered: potential kinetics, autocatalytic and proton dependant kinetics (due to the acid releasing), diffusive models and non-isothermal reactors (including the energy balance) (Haghighat Khajavi et al., 2005; Reynolds et al., 2015; Reynolds \& Smirnova, 2018; Rissanen et al., 2014).

$$
\frac{d C_{j}}{d t}=r_{j}=\sum_{i=1}^{N_{r}} g_{i j} \cdot k_{i} \cdot C_{j}=\sum_{i=1}^{N_{r}} g_{i j} \cdot k_{0_{i}} \cdot e^{-\frac{E a_{i}}{R \cdot T}} \cdot C_{j}
$$

Where $C_{j}$ is the concentration of the compound " $\mathrm{j}$ " in the liquid phase. The other variables have the same meaning as the described in section 1.2. Some values for the activation energy are: $54.6 \mathrm{~kJ} \cdot \mathrm{mol}^{-1}$ (for sugar production from peanut shell (Zhu et al., 2014)), 148 and $164 \mathrm{~kJ} \mathrm{~kJ} \cdot \mathrm{mol}^{-1}$ (for glucose production from corn starch and cellulose, respectively(Rogalinski et al., 2008)), 80 and $62 \mathrm{~kJ} \cdot \mathrm{mol}^{-1}$ (for sugar production from bean dregs and their degradation, respectively(Zhu et al., 2011)), $120 \mathrm{~kJ} \cdot \mathrm{mol}^{-1}$ (for hemicellulose fractionation from spruce (Rissanen et al., 2014)) and 143, 159 and 138 $\mathrm{kJ} \cdot \mathrm{mol}^{-1}$ (for oligomer, sugar and degradation product formation during the HTF of sugarcane bagasse, respectively (Santucci et al., 2015)). 


\section{Introduction}

\section{Thesis objectives}

The overall aim is to study the modelling of three of the most "green" common processes for biomass upgrading: SFE, pyrolysis and HTF. Also developing tools to simulate these processes, which allows the validation of the proposed models.

The aim of this thesis is to create user-friendly but precise mathematical tools to simulate fractionation processes for biorefineries.

This overall target will be developed through the following specific objectives.

\subsection{Supercritical Fluid Extraction (SFE)}

Develop a new SFE model based on the concepts used by the Broken Intact Cells model (the fact that there are diverse kinds of solute in terms of their easiness to be extracted). This model should be consistent with the classic mass transfer theory but, it should be understandable by anyone without a deep knowledge about the mass transfer phenomena involved in an extraction column. Additionally, an user-friendly Excel interface should be also developed to adjust the extraction yields and to simulate the dynamic concentration profiles inside the extraction column.

The work related with SFE can be seen in Chapter 1.

\subsection{Pyrolysis}

Develop a new model for pyrolysis of biomass (based on the Waterloo's mechanism) in order to reproduce the thermogram obtained by the TGA of any biomass and its individual components (water, oils, hemicellulose, cellulose and lignin).

Thus, this model should be validated for a wide range of biomasses, like wood or crop wastes. The specific target is twofold. On the one hand, it should be able to be used to estimate the initial composition of the sample just from the final TGA curve. And, on the other, the kinetics obtained during the fitting should be able to show the effect of the structure and composition on the thermal behaviour.

Moreover, this modelling should be general enough to be used under any condition in a TGA, like using different heating rates or atmospheres (oxidant and inter). This study was done in Chapters 2 and 3. 


\section{Introduction}

\subsection{Hydrothermal Fractionation (HTF)}

Finally, for HTF, this thesis is aimed at developing a new and realistic model that can reproduce the global experimental behaviour. Thus, the model should be able to simulate the profiles of: oligomers, sugars, acetic acid, $\mathrm{pH}$ and degradation products. The study is focused in a packed bed reactor since it is supposed to be the more effective way to treat biomass. Furthermore, during the modelling, the idea is to understand how the THF takes place and analyse the effect of the main operational variables, such as particle diameter, operating temperature and liquid flow rate. So, the whole set of physic-chemical phenomena involved, and not just some basic aspects, should be included in the model. This means that the effect of the $\mathrm{pH}$, porosity variations, solubility of the different biomass fractions, the mass transfer between the solid and the water and the cleavage process should be considered. The results for the THF of biomass can be seen in Chapters 4 and 5 .

\section{Thesis methodology}

The procedure followed to achieve each individual aim was always the same and it consists of four different tasks:

- Task 1: literature review

The first task consists of the review of the preliminary works about the topic to have an idea about the state of the art. The main objective of this review is to check the previous models about the topic and the experimental trends obtained by other authors. Thus, a deep analysis of the phenomena involved in the considered process (pyrolysis, HTF and SFE) is done, also defining the main variables to consider and their role.

- Task 2: model proposal

Once the available options for the modelling have been assessed and the basis behind the process has been understood, a novel model is set. This new model should include the main events that take place during the studied process. Thereby, it would be overall enough to be used for any initial raw material.

- Task 3: model resolution

Since the proposed model usually is a set of differential equations, its resolution is not straightforward. If the model has partial differential equations, the first step is to transform 


\section{Introduction}

them into ordinary differential equations. A transformation that is done by the orthogonal collocation method on finite elements. This method was selected since it requires lower calculation time than a conventional finite differences method. Once the set is just composed of ordinary differential equations, the Runge-Kutta's method with an $8^{\text {th }}$ order of convergence is used to solve it. All these calculations are done in a dynamic library $(\mathrm{C}++)$ that was specifically programmed during this task.

- Task 4: model validation

Finally, the simulation obtained with the dynamic library developed in the task 3 is compared with the experimental data. Their difference is minimised by an optimisation method (usually a modification of the Newton-Raphson's method) by an Excel interface. Likewise the dynamic library, this interface is specifically devolved for each process studied. Additionally, an analysis of the parameters obtained during the optimisation is also performed to ensure their physical meaning.

\section{References}

Anca-Couce, A. 2016. Reaction mechanisms and multi-scale modelling of lignocellulosic biomass pyrolysis. Progress in Energy and Combustion Science, 53, 41-79.

Arregi, A., Amutio, M., Lopez, G., Bilbao, J., Olazar, M. 2018. Evaluation of thermochemical routes for hydrogen production from biomass: A review. Energy Conversion and Management, 165, 696-719.

Biney, P.O., Gyamerah, M., Shen, J., Menezes, B. 2015. Kinetics of the pyrolysis of arundo, sawdust, corn stover and switch grass biomass by thermogravimetric analysis using a multi-stage model. Bioresource Technology, 179, 113-122.

Bobleter, O. 1994. Hydrothermal degradation of polymers derived from plants. Progress in Polymer Science, 19(5), 797-841.

Bozell, J.J. 2008. Feedstocks for the future - Biorefinery production of chemicals from renewable carbon. Clean - Soil, Air, Water, 36(8), 641-647.

Cabeza, A., Sobrón, F., Yedro, F.M., García-Serna, J. 2015. Autocatalytic kinetic model for thermogravimetric analysis and composition estimation of biomass and polymeric fractions. Fuel, 148, 212-225.

Cai, J., Wu, W., Liu, R. 2014. An overview of distributed activation energy model and its application in the pyrolysis of lignocellulosic biomass. Renewable and Sustainable Energy Reviews, 36, 236-246. 


\section{Introduction}

Cantero, D.A., Bermejo, M.D., Cocero, M.J. 2013. Kinetic analysis of cellulose depolymerization reactions in near critical water. The Journal of Supercritical Fluids, 75(0), 48-57.

Capart, R., Khezami, L., Burnham, A.K. 2004. Assessment of various kinetic models for the pyrolysis of a microgranular cellulose. Thermochimica Acta, 417(1), 79-89.

Clark, J.H., Budarin, V., Deswarte, F.E.I., Hardy, J.J.E., Kerton, F.M., Hunt, A.J., Luque, R., Macquarrie, D.J., Milkowski, K., Rodriguez, A., Samuel, O., Tavener, S.J., White, R.J., Wilson, A.J. 2006. Green chemistry and the biorefinery: A partnership for a sustainable future. Green Chemistry, 8(10), 853-860.

Cocero, M.J., Cabeza, Á., Abad, N., Adamovic, T., Vaquerizo, L., Martínez, C.M., PazoCepeda, M.V. 2018. Understanding biomass fractionation in subcritical \& supercritical water. The Journal of Supercritical Fluids, 133, 550-565.

Charles, E.W., Stephen, R.D., Michael, E.H., John, W.B., Catherine, E.S., Liisa, V. 2004. Hydrolysis of Cellulose and Hemicellulose. in: Polysaccharides, CRC Press.

Chen, Q., Zhou, J., Liu, B., Mei, Q., Luo, Z. 2011a. Influence of torrefaction pretreatment on biomass gasification technology. Chinese Science Bulletin, 56(14), 14491456.

Chen, Q., Zhou, J.S., Liu, B.J., Mei, Q.F., Luo, Z.Y. 2011b. Influence of torrefaction pretreatment on biomass gasification technology. Chinese Science Bulletin, 56(14), 1449-1456.

Chen, W.-H., Kuo, P.-C. 2011. Isothermal torrefaction kinetics of hemicellulose, cellulose, lignin and xylan using thermogravimetric analysis. Energy, 36(11), 6451-6460.

Cheng, K., Winter, W.T., Stipanovic, A.J. 2012. A modulated-TGA approach to the kinetics of lignocellulosic biomass pyrolysis/combustion. Polymer Degradation and Stability, 97(9), 1606-1615.

Cheng, S., Zhu, S. 2009. Lignocellulosic feedstock biorefinery-the future of the chemical and energy industry. BioResources, 4(2), 456-457.

da Silva, R.P.F.F., Rocha-Santos, T.A.P., Duarte, A.C. 2016. Supercritical fluid extraction of bioactive compounds. TrAC Trends in Analytical Chemistry, 76, 4051.

Daouk, E., Van de Steene, L., Paviet, F., Salvador, S. 2015. Thick wood particle pyrolysis in an oxidative atmosphere. Chemical Engineering Science, 126, 608-615. 


\section{Introduction}

Das, O., Sarmah, A.K. 2015. Mechanism of waste biomass pyrolysis: Effect of physical and chemical pre-treatments. Science of the Total Environment, 537, 323-334.

de Melo, M.M.R., Silvestre, A.J.D., Silva, C.M. 2014. Supercritical fluid extraction of vegetable matrices: Applications, trends and future perspectives of a convincing green technology. The Journal of Supercritical Fluids, 92, 115-176.

Demirbas, A. 2010. Biorefinery Technologies for Biomass Upgrading. Energy Sources, Part A: Recovery, Utilization, and Environmental Effects, 32(16), 1547-1558.

Deneyer, A., Ennaert, T., Sels, B.F. 2018. Straightforward sustainability assessment of sugar-derived molecules from first-generation biomass. Current Opinion in Green and Sustainable Chemistry, 10, 11-20.

Dimitriadis, A., Bezergianni, S. 2017. Hydrothermal liquefaction of various biomass and waste feedstocks for biocrude production: A state of the art review. Renewable and Sustainable Energy Reviews, 68, 113-125.

Döker, O., Salgin, U., Yildiz, N., Aydoğmuş, M., Çalimli, A. 2010. Extraction of sesame seed oil using supercritical $\mathrm{CO} 2$ and mathematical modeling. Journal of Food Engineering, 97(3), 360-366.

Elyounssi, K., Collard, F.-X., Mateke, J.-a.N., Blin, J. 2012. Improvement of charcoal yield by two-step pyrolysis on eucalyptus wood: A thermogravimetric study. Fuel, 96, 161-167.

Gallina, G., Cabeza, Á., Grénman, H., Biasi, P., García-Serna, J., Salmi, T. 2018. Hemicellulose extraction by hot pressurized water pretreatment at $160^{\circ} \mathrm{C}$ for 10 different woods: Yield and molecular weight. The Journal of Supercritical Fluids, $133,716-725$.

Garrote, G., Domínguez, H., Parajó, J.C. 2002. Interpretation of deacetylation and hemicellulose hydrolysis during hydrothermal treatments on the basis of the severity factor. Process Biochemistry, 37(10), 1067-1073.

Gollakota, A.R.K., Kishore, N., Gu, S. 2018. A review on hydrothermal liquefaction of biomass. Renewable and Sustainable Energy Reviews, 81, 1378-1392.

Haghighat Khajavi, S., Kimura, Y., Oomori, T., Matsuno, R., Adachi, S. 2005. Kinetics on sucrose decomposition in subcritical water. LWT - Food Science and Technology, 38(3), 297-302.

Henley, E.J., Seader, J.D. 1981. Equilibrium-Stage Separation Operations in Chemical Engineering. John Wiley \& Sons, Inc. 


\section{Introduction}

Herrero, M., Mendiola, J.A., Cifuentes, A., Ibáñez, E. 2010. Supercritical fluid extraction: Recent advances and applications. Journal of Chromatography A, 1217(16), 24952511.

Hu, M., Chen, Z., Wang, S., Guo, D., Ma, C., Zhou, Y., Chen, J., Laghari, M., Fazal, S., Xiao, B., Zhang, B., Ma, S. 2016. Thermogravimetric kinetics of lignocellulosic biomass slow pyrolysis using distributed activation energy model, Fraser-Suzuki deconvolution, and iso-conversional method. Energy Conversion and Management, 118, 1-11.

Huang, Z., Shi, X.-h., Jiang, W.-j. 2012. Theoretical models for supercritical fluid extraction. Journal of Chromatography A, 1250, 2-26.

Jahirul, M., Rasul, M., Chowdhury, A., Ashwath, N. 2012. Biofuels Production through Biomass Pyrolysis - A Technological Review. Energies, 5(12), 4952.

Kabir, G., Hameed, B.H. 2017. Recent progress on catalytic pyrolysis of lignocellulosic biomass to high-grade bio-oil and bio-chemicals. Renewable and Sustainable Energy Reviews, 70, 945-967.

Kan, T., Strezov, V., Evans, T.J. 2016. Lignocellulosic biomass pyrolysis: A review of product properties and effects of pyrolysis parameters. Renewable and Sustainable Energy Reviews, 57, 1126-1140.

Kastanaki, E., Vamvuka, D., Grammelis, P., Kakaras, E. 2002. Thermogravimetric studies of the behavior of lignite-biomass blends during devolatilization. Fuel Processing Technology, 77-78, 159-166.

King, D. 2009. The future of industrial biorefineries. Worl Economic Forum.

Knez, Ž., Markočič, E., Leitgeb, M., Primožič, M., Knez Hrnčič, M., Škerget, M. 2014. Industrial applications of supercritical fluids: A review. Energy, 77, 235-243.

Lin, R., Cheng, J., Ding, L., Song, W., Qi, F., Zhou, J., Cen, K. 2015. Subcritical water hydrolysis of rice straw for reducing sugar production with focus on degradation by-products and kinetic analysis. Bioresource Technology, 186, 8-14.

Lv, D., Xu, M., Liu, X., Zhan, Z., Li, Z., Yao, H. 2010. Effect of cellulose, lignin, alkali and alkaline earth metallic species on biomass pyrolysis and gasification. Fuel Processing Technology, 91(8), 903-909.

M. Sefik Tunc, A.R.P.v.H. 2008. Hemicellulose extraction of mixed southern hardwood with water at $150{ }^{\circ} \mathrm{C}$ : Effect of time. Industrial \& Engineering Chemistry Research, 47(18), 7031-7037. 


\section{Introduction}

Mangut, V., Sabio, E., Gañán, J., González, J.F., Ramiro, A., González, C.M., Román, S., Al-Kassir, A. 2006. Thermogravimetric study of the pyrolysis of biomass residues from tomato processing industry. Fuel Processing Technology, 87(2), 109-115.

Manivannan, G., Sawan, S.P. 1998. 1 - The Supercritical State. in: Supercritical Fluid Cleaning, (Ed.) J.M.P. Sawan, William Andrew Publishing. Westwood, NJ, pp. $1-21$.

Mohan, M., Banerjee, T., Goud, V.V. 2015. Hydrolysis of bamboo biomass by subcritical water treatment. Bioresource Technology, 191, 244-252.

Moniz, P., Pereira, H., Quilhó, T., Carvalheiro, F. 2013. Characterisation and hydrothermal processing of corn straw towards the selective fractionation of hemicelluloses. Industrial Crops and Products, 50(0), 145-153.

Mullen, C.A., Boateng, A.A. 2008. Chemical Composition of Bio-oils Produced by Fast Pyrolysis of Two Energy Crops. Energy \& Fuels, 22(3), 2104-2109.

Nahar, L., Sarker, S. 2012. Supercritical Fluid Extraction in Natural Products Analyses. in: Natural Products Isolation, (Eds.) S.D. Sarker, L. Nahar, Vol. 864, Humana Press, pp. 43-74.

OCDE. 2009. The Bioeconomy to 2030: designing a policy agenda, Vol. 2014.

Ogawa, T., Koizumi, S., Adachi, S. 2014. Thermal analysis of drying process of durum wheat dough under the programmed temperature-rising conditions. Food and Bioproducts Processing, 92(1), 9-13.

Organisation, T.E.P.S. 2011. THE EUROPEAN BIOECONOMY IN 2030. Delivering Sustainable Growth by addressing the Grand Societal Challenges, pp. 1-24.

Oudenhoven, S.R.G., van der Ham, A.G.J., van den Berg, H., Westerhof, R.J.M., Kersten, S.R.A. 2016. Using pyrolytic acid leaching as a pretreatment step in a biomass fast pyrolysis plant: Process design and economic evaluation. Biomass and Bioenergy, 95, 388-404.

Parajó, J.C., Garrote, G., Cruz, J.M., Dominguez, H. 2004. Production of xylooligosaccharides by autohydrolysis of lignocellulosic materials. Trends in Food Science \& Technology, 15(3-4), 115-120.

Piqueras, C.M., Cabeza, Á., Gallina, G., Cantero, D.A., García-Serna, J., Cocero, M.J. 2017. Online integrated fractionation-hydrolysis of lignocellulosic biomass using sub- and supercritical water. Chemical Engineering Journal, 308, 110-125. 


\section{Introduction}

Pronyk, C., Mazza, G. 2010. Kinetic modeling of hemicellulose hydrolysis from triticale straw in a pressurized low polarity water flow-through reactor. Industrial and Engineering Chemistry Research, 49(14), 6367-6375.

Radlein, D., Piskorz, J., Scott, D.S. 1991. Fast pyrolysis of natural polysaccharides as a potential industrial process. Journal of Analytical and Applied Pyrolysis, 19, 4163.

Ranzi, E., Cuoci, A., Faravelli, T., Frassoldati, A., Migliavacca, G., Pierucci, S., Sommariva, S. 2008. Chemical Kinetics of Biomass Pyrolysis. Energy \& Fuels, 22(6), 4292-4300.

Reynolds, W., Singer, H., Schug, S., Smirnova, I. 2015. Hydrothermal flow-through treatment of wheat-straw: Detailed characterization of fixed-bed properties and axial dispersion. Chemical Engineering Journal, 281, 696-703.

Reynolds, W., Smirnova, I. 2018. Hydrothermal flow-through treatment of wheat straw: Coupled heat and mass transfer modeling with changing bed properties. The Journal of Supercritical Fluids, 133, 625-639.

Rissanen, J.V., Grénman, H., Willför, S., Murzin, D.Y., Salmi, T. 2014. Spruce hemicellulose for chemicals using aqueous extraction: Kinetics, mass transfer, and modeling. Industrial and Engineering Chemistry Research, 53(15), 63416350.

Rivas, S., González-Muñoz, M.J., Santos, V., Parajó, J.C. 2014. Acidic processing of hemicellulosic saccharides from pine wood: Product distribution and kinetic modeling. Bioresource Technology, 162, 192-199.

Rogalinski, T., Liu, K., Albrecht, T., Brunner, G. 2008. Hydrolysis kinetics of biopolymers in subcritical water. The Journal of Supercritical Fluids, 46(3), 335341.

Ru, B., Wang, S., Dai, G., Zhang, L. 2015. Effect of Torrefaction on Biomass Physicochemical Characteristics and the Resulting Pyrolysis Behavior. Energy \& Fuels, 29(9), 5865-5874.

S. Völker, T.R. 2002. Thermokinetic investigation of cellulose pyrolysis. Impact of initial and final mass of kinetics results. Journal of Analytical and Applied Pyrolysis, 62, 165-177.

Santucci, B.S., Maziero, P., Rabelo, S.C., Curvelo, A.A.S., Pimenta, M.T.B. 2015. Autohydrolysis of Hemicelluloses from Sugarcane Bagasse During Hydrothermal Pretreatment: a Kinetic Assessment. BioEnergy Research, 8(4), 1778-1787. 


\section{Introduction}

Sasaki, M., Furukawa, M., Minami, K., Adschiri, T., Arai, K. 2002. Kinetics and mechanism of cellobiose hydrolysis and retro-aldol condensation in subcritical and supercritical water. Industrial and Engineering Chemistry Research, 41(26), 6642-6649.

Scott, S.A., Dennis, J.S., Davidson, J.F., Hayhurst, A.N. 2006. An algorithm for determining the kinetics of devolatilisation of complex solid fuels from thermogravimetric experiments. Chemical Engineering Science, 61(8), 23392348.

Seo, D.K., Park, S.S., Hwang, J., Yu, T.-U. 2010. Study of the pyrolysis of biomass using thermo-gravimetric analysis (TGA) and concentration measurements of the evolved species. Journal of Analytical and Applied Pyrolysis, 89(1), 66-73.

Serapiglia, M.J., Cameron, K.D., Stipanovic, A.J., Smart, L.B. 2009. Analysis of Biomass Composition Using High-Resolution Thermogravimetric Analysis and Percent Bark Content for the Selection of Shrub Willow Bioenergy Crop Varieties. BioEnergy Research, 2(1), 1-9.

Serapiglia, M.J., Cameron, K.D., Stipanovic, A.J., Smart, L.B. 2008. High-resolution Thermogravimetric Analysis For Rapid Characterization of Biomass Composition and Selection of Shrub Willow Varieties. Applied Biochemistry and Biotechnology, 145(1), 3-11.

Shafizadeh, F. 1982. Introduction to pyrolysis of biomass. Journal of Analytical and Applied Pyrolysis, 3(4), 283-305.

Sharma, A., Pareek, V., Wang, S., Zhang, Z., Yang, H., Zhang, D. 2014. A phenomenological model of the mechanisms of lignocellulosic biomass pyrolysis processes. Computers \& Chemical Engineering, 60, 231-241.

Sharma, A., Pareek, V., Zhang, D. 2015. Biomass pyrolysis-A review of modelling, process parameters and catalytic studies. Renewable and Sustainable Energy Reviews, 50, 1081-1096.

Slopiecka, K., Bartocci, P., Fantozzi, F. 2012. Thermogravimetric analysis and kinetic study of poplar wood pyrolysis. Applied Energy, 97, 491-497.

Sovová, H. 1994. Rate of the vegetable oil extraction with supercritical CO2-I. Modelling of extraction curves. Chemical Engineering Science, 49(3), 409-414.

Sunarso, J., Ismadji, S. 2009. Decontamination of hazardous substances from solid matrices and liquids using supercritical fluids extraction: A review. Journal of Hazardous Materials, 161(1), 1-20. 


\section{Introduction}

Tekin, K., Karagöz, S., Bektaş, S. 2014. A review of hydrothermal biomass processing. Renewable and Sustainable Energy Reviews, 40, 673-687.

Van de Velden, M., Baeyens, J., Brems, A., Janssens, B., Dewil, R. 2010. Fundamentals, kinetics and endothermicity of the biomass pyrolysis reaction. Renewable Energy, $35(1), 232-242$.

van der Stelt, M.J.C., Gerhauser, H., Kiel, J.H.A., Ptasinski, K.J. 2011. Biomass upgrading by torrefaction for the production of biofuels: A review. Biomass and Bioenergy, 35(9), 3748-3762.

Völker, S., Rieckmann, T. 2002. Thermokinetic investigation of cellulose pyrolysis impact of initial and final mass on kinetic results. Journal of Analytical and Applied Pyrolysis, 62(2), 165-177.

Wang, S., Dai, G., Yang, H., Luo, Z. 2017. Lignocellulosic biomass pyrolysis mechanism: A state-of-the-art review. Progress in Energy and Combustion Science, 62, 33-86.

Widjaya, E.R., Chen, G., Bowtell, L., Hills, C. 2018. Gasification of non-woody biomass: A literature review. Renewable and Sustainable Energy Reviews, 89, 184-193.

Williams, P.T., Besler, S. 1996. The influence of temperature and heating rate on the slow pyrolysis of biomass. Renewable Energy, 7(3), 233-250.

Yoo, C.G., Pu, Y., Ragauskas, A.J. 2017. Ionic liquids: Promising green solvents for lignocellulosic biomass utilization. Current Opinion in Green and Sustainable Chemistry, 5, 5-11.

Zabaniotou, A., Ioannidou, O., Antonakou, E., Lappas, A. 2008. Experimental study of pyrolysis for potential energy, hydrogen and carbon material production from lignocellulosic biomass. International Journal of Hydrogen Energy, 33(10), 24332444.

Zakaria, M.R., Hirata, S., Hassan, M.A. 2015. Hydrothermal pretreatment enhanced enzymatic hydrolysis and glucose production from oil palm biomass. Bioresource Technology, 176(0), 142-148.

Zhu, G., Zhu, X., Fan, Q., Wan, X. 2011. Production of reducing sugars from bean dregs waste by hydrolysis in subcritical water. Journal of Analytical and Applied Pyrolysis, 90(2), 182-186.

Zhu, G., Zhu, X., Xiao, Z., Zhou, R., Zhu, Y., Wan, X. 2014. Kinetics of peanut shell pyrolysis and hydrolysis in subcritical water. Journal of Material Cycles and Waste Management, 16(3), 546-556. 


\section{Introduction}


ABSTRACT 

Nowadays, biomass revalorisation is one of the most studied fields since it means the production of chemicals and energy from a renewable source. Thus, several and different processes have been developed. Among all of them, there are three especially remarkable since they just require a "green" fluid, such as water or carbon dioxide, and heat to do this biomass upgrading. These processes are: supercritical fluid extraction (SFE), pyrolysisgasification and hydrothermal fractionation (HTF). For this reason, this thesis is focused on the modelling and simulation of these three processes. The general idea was to propose overall models, based on pseudo-compounds, to reproduce the experimental behaviour observed in the laboratory. The specific aims for each process were: (1) a new model for SFE, easily understandable, based on the Broken Intact Cells model, (2) an overall model for pyrolysis (based on the Waterloo's mechanism) to estimate the initial sample composition and to analyse the structure role on thermal degradation and (3), a realistic model for the HTF of biomass in a packed bed reactor.

Regarding SFE, its fundamentals have been deeply studied and a great deal of models can be found in literature. However, they generally require high knowledge about mass transfer. A knowledge that is not shared by the whole potential users of this technology. Thus, an innovative approach, solved by a free user-friendly Excel interface, was proposed in this thesis. This novel model involved non-stationary mass balances for the extracted compounds in both phases (solid and supercritical fluid) and it was based on the extraction characteristic times of the initial sample, which makes it far easier to understand the mass transfer. The validation was done by experimental data of samples where the mass transfer limitation was different: sesame seeds (controlled by external mass transfer and equilibrium) and coffee beans (controlled by internal diffusion). The equilibrium between the solid and liquid phases was simulated by a Henry's linear relation and the average error of the model was lower than $11 \%$.

Similarly to SFE, biomass pyrolysis (or gasification if an oxidant is used) is a well known process and a huge number of studies about its modelling have been previously done. But, again, they need a deep knowledge about mass transfer and kinetics. Additionally, biomass pyrolysis is involved in one of the most used techniques to characterise a solid material, the thermogravimetric analysis (TGA). For these reasons, a kinetic model to simulate the slow pyrolysis of biomass during a TGA has been developed. This model was solved by another free user-friendly Excel interface and it could be used to easily analyse the effect of the heating rates, operational mode (isothermal or not), pre- 


\begin{abstract}
treatments, atmosphere type (oxidant or not), raw material composition and biomass structure on the thermal behaviour of the sample. The reaction pathway was a modification of the Waterloo's mechanism: any solid can produce gases and char, a char that can further degrade into more gases. Furthermore, this mechanism was completed by the vaporization of any liquid phase in the initial raw material. Auto-catalytic kinetics were used since the cleavage of the biomass produce oligomers that accelerate the further depolymerisation. The validation of the proposed model was done with data from completely different samples (pure hemicellulose, cellulose and lignin, woody biomass and winery residues) and the average error was always below $7 \%$.
\end{abstract}

Finally, HTF of biomass has been also previously studied. Nevertheless, a comprehensive physic-chemical model has not been utterly developed. Thus, a kinetic realistic model was proposed in this thesis. A model that also incorporates a novel reaction pathway for biomass fractionation, including the main processes involved. These processes are: biomass cleavage, biomass solubilisation, sugar production, $\mathrm{pH}$ changes and the mass transfer between both phases, the liquid and the water. With regards to the kinetics, an autocatalytic expression was again used to simulate the biomass depolymerisation. The model was validated by data about the hydrothermal fractionation of holm oak in a packed reactor at several temperatures around $180{ }^{\circ} \mathrm{C}$ (to boost hemicellulose extraction). Additionally, different particle diameters and volumetric flows were also considered. However, the main variable was always the operational temperature. The fittings were focused on carbon content profiles, being the average error around $33 \%$. On the other hand, a populational model was also developed for the HTF of biomass. The aim was to complete the kinetic model by a more realistic simulation of the cleavage (up to 200 oligomers were simulated). Furthermore, sugar degradation and repolymerisation reactions were also included in this case since the data obtained at temperatures as high as $280^{\circ} \mathrm{C}$.

In summary, novel models for the simulation of the biomass pyrolysis, biomass extraction by supercritical fluids and biomass hydrothermal have been proposed and validated in this thesis. These models were able to accurately reproduce the experimental behaviour and they constitute a useful tool for a better understanding of the considered processes. Additionally, since they were solved by Excel-interface tools, they can be directly used by a wide range of people or being connected to commercial process simulators, like Aspen plus. 
Resumen

RESUMEN 



\section{Resumen}

La revalorización de biomasa es uno de los procesos más estudiados actualmente ya que se basa en la producción de combustibles y productos químicos a partir de una fuente renovable. Debido a ello, y a pesar de que hay una gran cantidad de procesos desarrollados para dicha revalorización, aún hoy se siguen buscando nuevas formas de llevarla a cabo. De entre todos estos procesos ya desarrollados, hay tres que destacan sobre el resto: la pirólisis, la extracción con fluidos supercríticos (EFS) y el fraccionamiento hidrotermal (FHT).

La EFS se basa en la recuperación de compuestos (solutos), retenidos en un sólido o un líquido, utilizando un fluido supercrítico. Un fluido pasa al estado supercrítico cuando las condiciones de operación están por encima de su punto crítico. El interés de alcanzar dicho estado radica en que, en ese estado, la materia muestra propiedades intermedias entre gases (buena difusividad) y líquidos (buena densidad). De igual modo, las propiedades dieléctricas se ven también afectadas, pudiendo pasar de fluidos polares a apolares (cómo en el caso del agua). Además, el control de las propiedades de transporte es relativamente sencillo: se modifican directamente mediante cambios en la presión y la temperatura. Otra ventaja es que, simplemente con una despresurización, el compuesto extraído y el solvente se separan completamente. El principal inconveniente está en que alcanzar el estado supercrítico suele requerir condiciones extremas de presión y temperatura. Pero existen opciones realmente económicas, como el $\mathrm{CO}_{2}$, cuyo punto crítico es de tan solo $31,1^{\circ} \mathrm{C}$ y 73,8 bar. Lo que hace que sea uno de los más utilizados.

Respecto a la pirolisis, es uno de los procesos clásicos para revalorización de biomasa. Básicamente consiste en tratar la materia prima con un gas caliente, lo que lleva a la ruptura térmica de los enlaces de los constituyentes de dicha materia, produciendo gases, líquidos y un residuo carbonoso, el charcoal. Este proceso se ve afectado por una gran cantidad de variables, cómo la velocidad de calentamiento, el tipo de gas (inerte u oxidante) o la temperatura final del proceso. Y, dependiendo de los valores de dichas variables, la cantidad y composición de cada uno de los tres productos (gas, líquidos y el charcoal) es distinta. Por otro lado, la pirolisis es también el proceso involucrado en uno de los análisis más utilizados para caracterizar un sólido: el análisis termogravimétrico (TGA). Durante este análisis, una muestra de unos $10 \mathrm{mg}$ se somete a un perfil de temperatura aportado por un flujo de gas, degradándola. Esta degradación conlleva una variación en la masa de la muestra, la cual es medida mediante una balanza analítica. La representación de esta variación de la masa frente a la temperatura o el tiempo de 


\section{Resumen}

operación es lo que se conoce como el termograma y permite obtener información sobre el comportamiento termal de la muestra y sobre la composición de esta.

En cuanto al fraccionamiento hidrotermal, este proceso busca la recuperación de los compuestos principales de la biomasa (hemicelulosa, celulosa y lignina) mediante el uso de agua presurizada caliente. El uso de agua caliente permite la ruptura de los enlaces entre dichos componentes y entre los compuestos que los forman (azúcares en caso de la celulosa y la hemicelulosa y fenoles para la lignina), produciendo substancias solubles que se recuperan en el agua. Sin embargo, para extraer celulosa y lignina se requieren condiciones tan extremas (entre 240 y $400{ }^{\circ} \mathrm{C}$ ) que, usualmente, se realiza mediante agua supercrítica en vez de agua presurizada caliente. Por ello, el FHT en condiciones subcríticas suele centrarse en la recuperación de la hemicelulosa (temperaturas en torno a $\left.180^{\circ} \mathrm{C}\right)$.

Puede comprobarse, por lo descrito anteriormente, que la principal característica de estos procesos es que son capaces de revalorizar la biomasa utilizando solamente un fluido inocuo para el medioambiente (como el agua o el nitrógeno) y una fuente de calor. Por tanto, esta revalorización se realiza sin la necesidad de usar ácidos o líquidos orgánicos. Es decir, estas tres tecnologías son, a la vez, procesos sostenibles y medioambientalmente amigables. Y, por ello, esta tesis se centra en su estudio.

\section{Objetivos}

El objetivo general a alcanzar es el desarrollo de modelos basados en pseudocomponentes para la reproducción de los comportamientos observados en el laboratorio que permitan un mejor estudio y cambios de escala de los procesos estudiados. Para cada proceso (EFS, FHT y pirolisis), los objetivos específicos son:

- Para la EFS el objetivo es desarrollar un nuevo modelo basado en los conceptos subyacentes del modelo de "celdas intactas y rotas": el hecho de que hay varios tipos de soluto en función de la facilidad que tienen para ser extraídos. Este nuevo modelo, además, debe ser coherente con los fundamentos básicos de transferencia de materia. De igual modo, el modelo propuesto debe poder ser utilizado por cualquier persona interesada en esta tecnología, aunque no tenga amplios conocimientos sobre la fenomenología asociada a una columna de extracción (que es el sistema estudiado). Para ello, también se busca desarrollar una interfaz en Excel que permita su resolución. 


\section{Resumen}

- En cuanto al fraccionamiento hidrotermal, el objetivo específico es el planteamiento de un nuevo modelo para el proceso. Este modelo debe incluir los principales fenómenos fisicoquímicos asociados (como los cambios en el pH o en la porosidad) y debe ser capaz de reproducir los perfiles a la salida del sistema estudiado (un reactor tubular).

- Finalmente, el objetivo a alcanzar para la pirolisis es el desarrollo de un modelo basado en el mecanismo de Waterloo. La idea es que este modelo pueda reproducir la degradación térmica de cualquier biomasa y de sus componentes individuales (hemicelulosa, celulosa y lignina) así como de las fases líquidas que pueden estar presentes en la biomasa inicial (agua y líquidos orgánicos).

\section{Metodología}

La metodología seguida fue siempre la siguiente: (1) revisión bibliográfica de los modelados y trabajos previos, (2) desarrollo de un nuevo modelo a partir de la información obtenida en la revisión bibliográfica y nuestros experimentos, (3) desarrollo del programa para la resolución del modelo propuesto y (4) validación del modelo con el programa previamente desarrollado.

\section{Resultados y discusión}

En el Capítulo 1 se realizó el estudio sobre el modelado para la EFS de biomasa en una columna de extracción. El modelo se desarrolló asumiendo (1) una porosidad del lecho constante, (2) que no existe transporte difusivo a lo largo de la columna y (3) una isoterma lineal (Henry). El modelo en sí se obtuvo aplicando un balance de materia convencional en régimen no estacionario al pseudocomponente extraído en ambas fases, el fluido supercrítico y el sólido. La principal modificación propuesta en este trabajo se centró en el término de transferencia de materia. Se definió un coeficiente global de transferencia $(K \cdot a)$ que tuviera en cuenta el posible transporte difusivo dentro del sólido $\left(k_{s} \cdot a_{s}\right)$ y el transporte externo en las capas de fluido supercrítico alrededor de las partículas $\left(k_{S C F}\right.$.

$\left.a_{S C F}\right)$, pero en función de los tiempos característicos de la extracción $\left(t_{c_{1}} \mathrm{y} t_{c_{2}}\right)$. Estos tiempos se corresponden con los cambios en la pendiente que pueden observarse en una curva de extracción (Figura 1). De igual modo, estos tiempos se relacionan inversamente con la cantidad de soluto fácilmente extraíble $\left(t_{c_{1}}\right)$ y difícil de recuperar debido a 
problemas de difusión interna $\left(t_{c_{2}}\right)$. La definición de este coeficiente global puede verse en la Eq. ( 1 ), dónde $F$ hace referencia al soluto que puede ser recuperado sin demasiadas dificultades pero que es parcialmente afectado por la difusión interna y $t$ sería el tiempo de operación. De igual modo, puede comprobarse que la expresión propuesta es consistente con los principios clásicos de transferencia de materia.

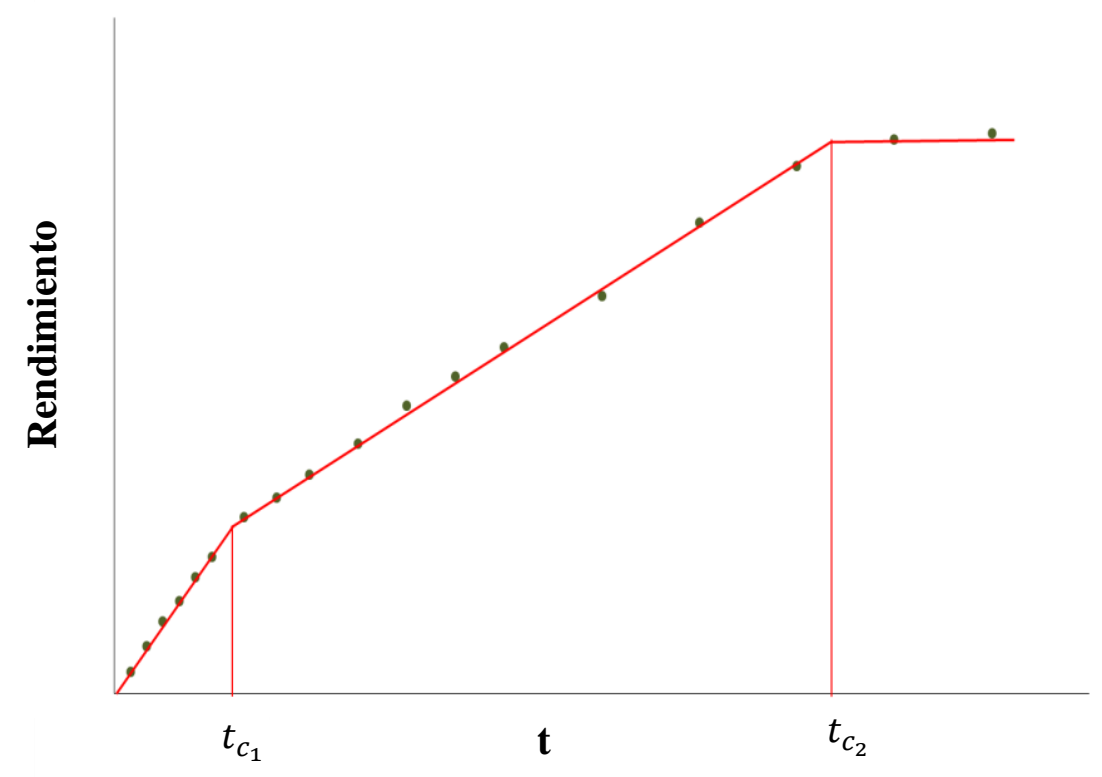

Figura 1. Curva de extracción típica.

$$
K \cdot a=\frac{k_{S C F} \cdot a_{S C F} \cdot\left(\frac{F}{1+e^{-\left(t-t_{c_{1}}\right)}}\right)}{1+e^{\left(t-t_{c_{2}}\right)}}+\frac{k_{S} \cdot a_{S}}{1+e^{-\left(t-t_{c_{2}}\right)}}
$$

Este modelo se validó utilizando datos de la extracción con $\mathrm{CO}_{2}$ supercrítico de dos materias primas diferentes (semillas de sésamo y granos de café) en los cuales la limitación principal a la transferencia de materia es diferente. En el caso de las semillas, controla el equilibrio entre fases y la transferencia de materia externa y, para los granos de café, está limitada por la difusión interna. También se consideró en la validación el efecto de la temperatura, presión, flujo volumétrico, diámetro de partícula y cosolventes. El modelo fue capaz de reproducir el comportamiento experimental para todos los casos, siendo la desviación entre el comportamiento simulado y el experimental siempre menor de un $11 \%$. La bondad del ajuste puede comprobarse también en la Figura. 2-a y 2-b para las semillas y los granos, respectivamente. 

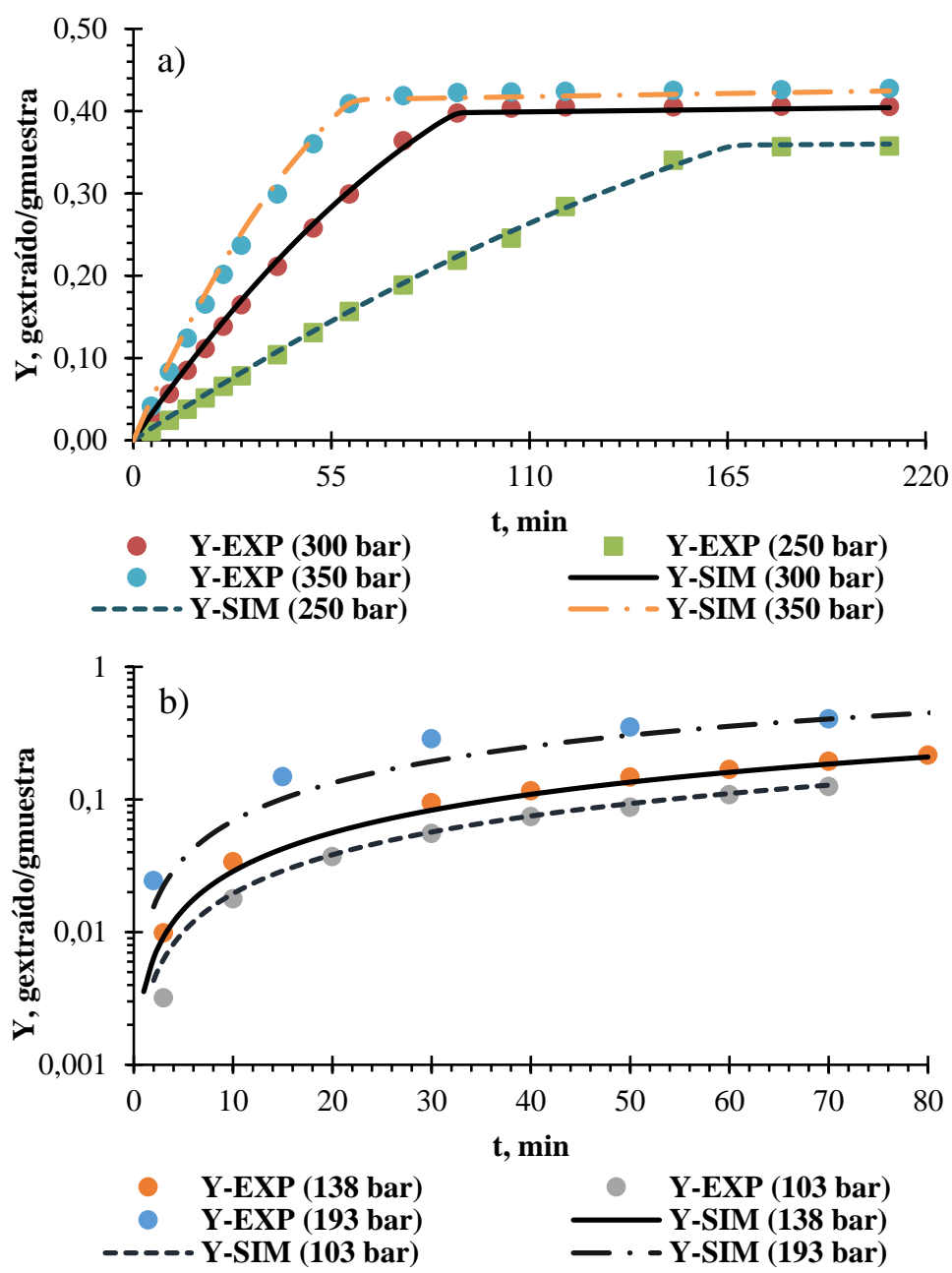

Figura 2. Ejemplo del ajuste de las curvas de extracción a distintas presiones para las semillas de sésamo (a) y los granos de café (b). Y-EXP: curva de extracción experimental y Y-SIM: curva de extracción simulada.

Finalmente, se procedió a comprobar el sentido físico de todos los parámetros calculados. El coeficiente de transferencia de materia externo $\left(k_{S C F} \cdot a_{S C F}\right)$ resultó ser función del diámetro de partícula (decreció con él) y del flujo volumétrico (incrementó con él). Respecto al coeficiente de transporte interno $\left(k_{s} \cdot a_{s}\right)$, fue independiente del flujo y mostró una tendencia inversamente proporcional al diámetro de partícula. En cuanto al factor $F$, disminuyó tanto con la presión como con el diámetro de partícula. Por otro lado, la constante de equilibrio calculada resulto ser función de la densidad del fluido supercrítico y el cosolvente. Por tanto, el comportamiento obtenido coincide con el teórico, siendo validado el significado físico de todos los parámetros. 


\section{Resumen}

En los Capítulos 2 y 3 se planteó el modelado para la pirólisis lenta de biomasa durante un análisis termogravimétrico. La principal diferencia entre los Capítulos 2 y 3 es que, en el primero, el estudio se centró en la degradación térmica de varias biomasas (17) utilizando una atmósfera inerte. Mientras que, en el Capítulo 3, se estudió la degradación de una misma biomasa (ginseng brasileño) sometida a distintos pretratamientos y bajo una atmósfera oxidante. El modelo propuesto es una modificación del mecanismo de Waterloo, el cual establece que todo componente solido presente en la muestra inicial degrada en gases y charcoal. La modificación se centró en asumir que dicho charcoal puede degradar produciendo más gases y en incluir la evaporación de los compuestos líquidos presentes en la biomasa (agua y líquidos orgánicos). El mecanismo para las sustancia sólidas presentes en la biomasa (hemicelulosa, celulosa y lignina) puede verse en la Figura 3.

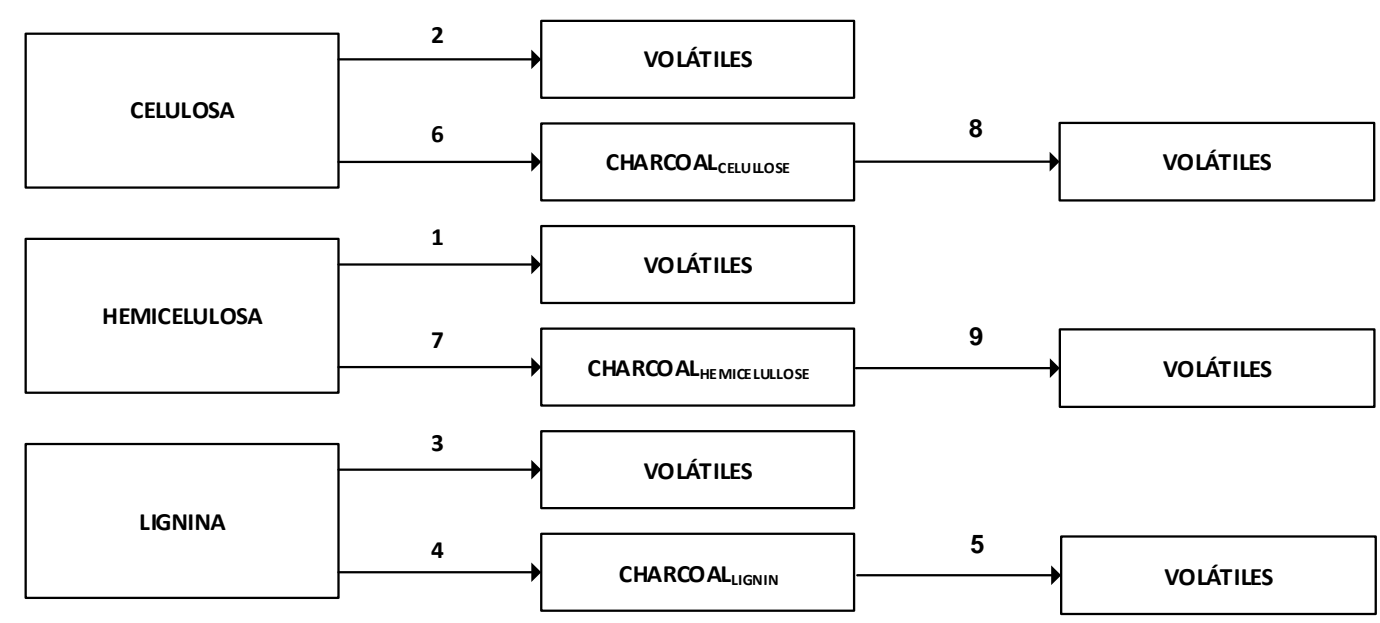

Figura 3. Mecanismo de reacción durante una pirólisis lenta.

El modelo se obtuvo planteando el balance de materia en régimen no estacionario para cada compuesto, asumiendo que (1) todas las reacciones son independientes e irreversibles, que (2) no hay limitaciones a la transferencia de energía (por lo que la temperatura en el sólido es homogénea) y que (3) no hay problemas de difusión en las fases líquidas. Por ello, finalmente, el balance de materia para cada compuesto (Eq. ( 2 )) fue una ecuación diferencial ordinaria en la que el término de acumulación $\left(d m_{j} / d t\right)$ equivale a la velocidad de reacción o transferencia de materia $\left(r_{j}\right)$, según sea el balance para un sólido o un líquido. La cinética utilizada para los sólidos fue de tipo auto-catalítico (ya que el proceso se auto-acelera una vez empieza) y la expresión para la transferencia de materia de los líquidos fue definida a partir del gradiente de concentración entre la capa de líquido y el gas. 


$$
\frac{d m_{j}}{d t}=r_{j}
$$

Este modelo fue validado en el Capítulo 2 con datos de la degradación térmica de las siguientes especies: hemicelulosa, celulosa y lignina puras, lignina alcalina, semillas de uva, semillas de uva sometidas a una extracción, semillas de uva hidrolizadas a 250, 300 y $340{ }^{\circ} \mathrm{C}$, hollejo de uva, platanero, encina, cedro, catalpa, almendro tilo y arce. El modelo fue capaz de reproducir su comportamiento con desviaciones menores al 7\% y para la hemicelulosa pura puede verse en la Figura 4. Estos ajustes requirieron distintos sets de parámetros cinéticos según la muestra estudiada y, a partir de la comparación de dichos sets, pudo concluirse que la estructura y composición iniciales de la muestra afectan en gran medida al comportamiento termal de la misma. Conclusión que también pudo obtenerse con la variación de las temperaturas característicos (temperatura a la cual se alcanza la máxima variación en la masa) de cada muestra. Por ejemplo, la temperatura característica pata la hemicelulosa pura fue $362{ }^{\circ} \mathrm{C}$, mientras que, en las maderas, dicha temperatura fue $304^{\circ} \mathrm{C}$. Estos resultados se corroboraron con el estudio realizado en el Capítulo 3, dónde se comprobó que los cambios estructurales (medidos mediante XRD y DSC) en el ginseng debido a los diferentes pretratamientos (cómo extracción con líquidos presurizados o sonificación) originaron, a su vez, un comportamiento térmico distinto con respecto a la muestra original.

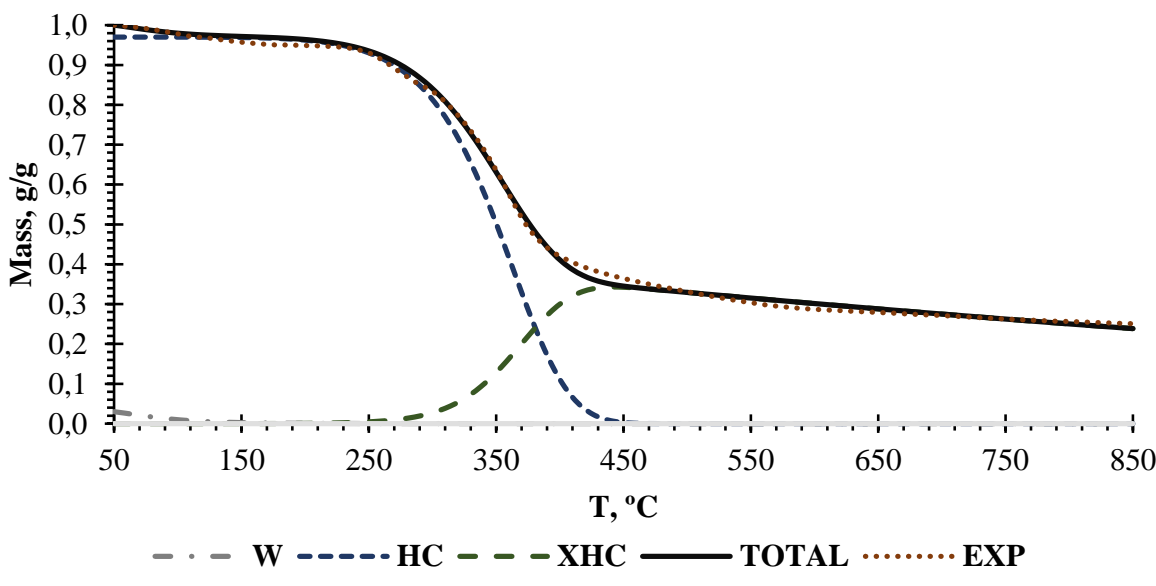

Figura 4. Ejemplo del ajuste de la degradación térmica de la hemicelulosa pura. W: termograma simulado para el agua; HC: termograma simulado para la hemicelulosa; XHC: termograma simulado para el charcoal de hemicelulosa; TOTAL: termograma simulado y EXP: termograma experimental.

Finalmente, en los Capítulos 4 y 5 se desarrolló el modelo para el FHT de biomasa. En el Capítulo 4 se planteó un mecanismo de reacción que tuviera en cuenta los principales 


\section{Resumen}

procesos asociados al fraccionamiento: despolimerización, formación de azúcares, disolución y trasferencia de materia, deacetilación, consumo de protones mediante reacciones de buffering y cambios en la porosidad. Además, las siguientes simplificaciones se tuvieron en cuenta a la hora de desarrollar el modelo: (1) la fase sólida es homogénea y uniforme, comportándose como un todo, (2) la porosidad del solido depende directamente de la concentración total en el sólido, (3) no hay transporte difusional en la fase líquida o sólida, (4) la lignina se comporta como un inerte y (5) el orden de reacción es 1 para todas las especies. El modelo en si se obtuvo mediante balances en régimen no estacionario a cada componente en ambas fases. Para la fase líquida puede verse en la Eq. ( 3 ). Esta ecuación incluye el término de acumulación $\left(d C_{S_{j}} / d t\right)$, reacción $\left(r_{j}\right)$, efecto de la transferencia de materia en la porosidad $\left(\varphi \cdot C_{S_{j}}\right.$. $\left.d C_{t} / d t\right)$ y la transferencia de materia $\left(k_{j} \cdot a \cdot\left(C_{L_{j}}^{*}-\bar{C}_{L_{j}}\right)\right)$. El de la fase sólida es semejante, pero sin el término del transporte convectivo. Al igual que para la pirólisis, se utilizó una cinética autocatalítica debido a la autoaceleración del proceso.

$$
\frac{d C_{S_{j}}}{d t}=\frac{1}{1-\varepsilon} \cdot\left[r_{j}-\varphi \cdot C_{S_{j}} \cdot \frac{d C_{t}}{d t}-k_{j} \cdot a \cdot\left(C_{L_{j}}^{*}-\bar{C}_{L_{j}}\right)\right]
$$

Con este modelo se ajustaron los perfiles de contenido en carbono (TOC), concentración de ácido acético y $\mathrm{pH}$ del fraccionamiento hidrotermal de $5 \mathrm{~g}$ de encina en un reactor tubular de $27.5 \mathrm{~mL}$ de volumen a temperaturas en torno a $180{ }^{\circ} \mathrm{C}$. El ajuste se centró en el TOC y el modelo pudo reproducir bastante bien los perfiles experimentales (Figura 5), estando el error entre la simulación y los valores experimentales del TOC entre un $16 \%$ y un $56 \%$. Además, se procedió a estudiar el efecto del diámetro de partícula, temperatura de operación y flujo volumétrico en el fraccionamiento. De las tres, se observó que la principal variable fue la temperatura y que el flujo volumétrico centra su efecto, no tanto en la extracción en sí, si no en la degradación de los compuestos extraídos. Es decir, a mayor flujo, menor tiempo de residencia y menor degradación del producto líquido. Por otro lado, también se comprobó el significado físico de todos los parámetros: las constantes cinéticas fueron de tipo Arrhenius, los coeficientes de transferencia de materia fueron función del flujo y el diámetro de partícula, la constante de equilibrio dependió de la temperatura y el coeficiente autocatalítico dependió de ambos, flujo y temperatura, ya que es utilizado para reproducir la despolimerización de la hemicelulosa y celulosa. 

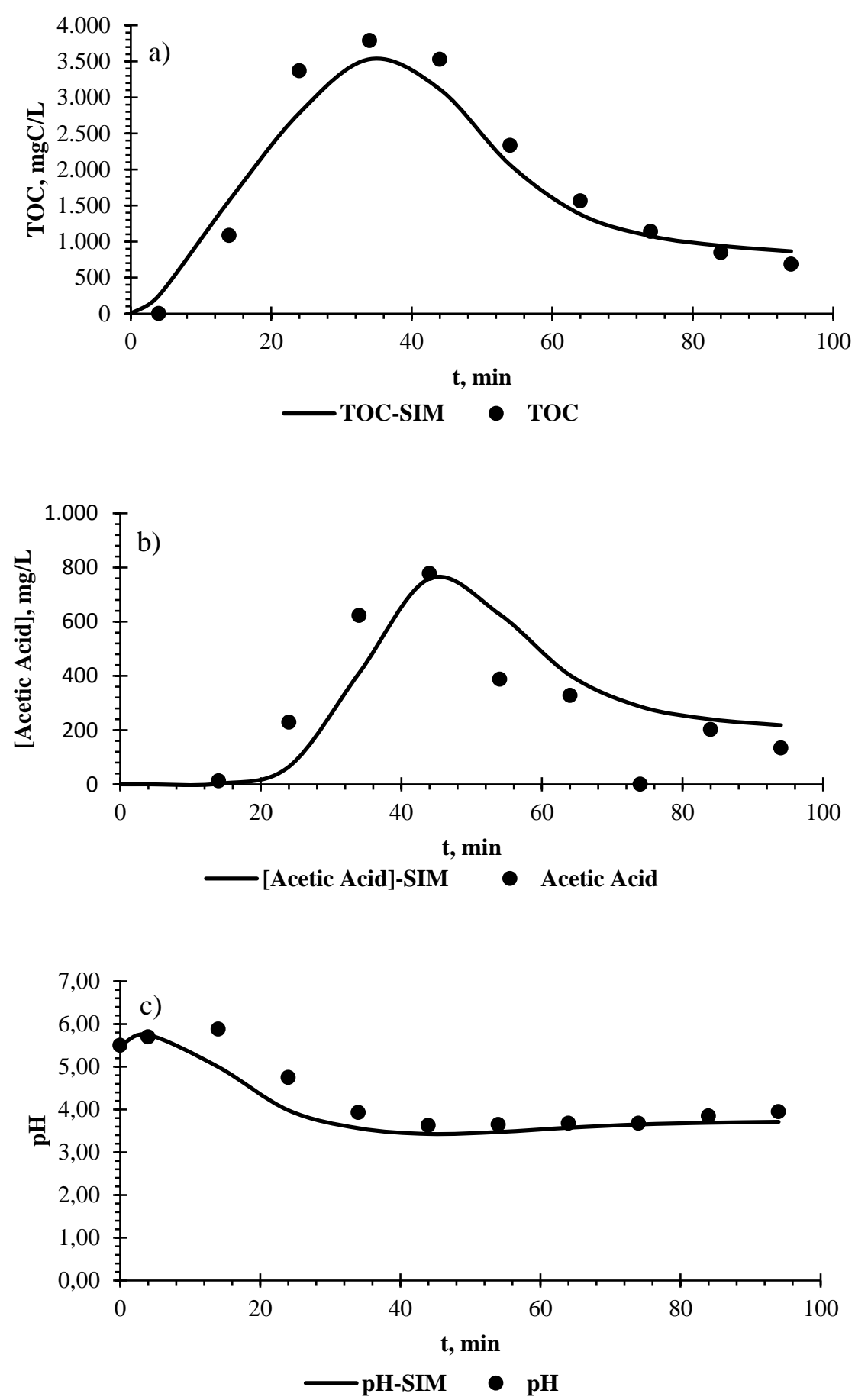

Figura 5. Ejemplo de los ajustes de los perfiles de TOC (a), ácido acético (b) y pH (c) usando el modelo del Capítulo 4. TOC: perfil experimental del TOC; TOC-SIM: perfil simulado para el TOC; [Acetic Acid]: perfil experimental del ácido acético; [Acetic Acid]-SIM: perfil simulado del ácido acético; pH: pH experimental y pH-SIM: pH simulado.

En el Capítulo 5, se volvió a estudiar el fraccionamiento de encina en el mismo reactor, pero en dos etapas. En la primera etapa, se realiza la extracción a temperaturas en torno a $180{ }^{\circ} \mathrm{C}$ para recuperar la hemicelulosa, mientras que, en la segunda, el sólido resultante de la primera etapa se trata con agua a temperaturas en torno a $260{ }^{\circ} \mathrm{C}$ para recuperar la 


\section{Resumen}

celulosa. El cambio de una etapa a otra se realizó mediante un seguimiento continuo del pH ya que, para la encina, el perfil de extracción y el de pH son simultáneos. Por lo que pequeñas variaciones en el pH implican que la extracción a las condiciones de operación es máxima, requiriéndose una mayor temperatura para seguir extrayendo. En cuanto al modelo, se utilizó la misma idea que en el Capítulo 4 pero con ciertas modificaciones. En el mecanismo de reacción (Figura 6) se incluyó la degradación de los azúcares obtenidos y la repolimerización. Estas reacciones se tuvieron en cuenta debido a la mayor temperatura de operación. Además, se utilizó un modelo poblacional para la mejor simulación de la despolimerización y se definieron constantes cinéticas y de equilibrio en función del peso molecular de los compuestos simulados. En cuanto a la validación, se volvieron a ajustar los perfiles a la salida del reactor de TOC, ácido acético y pH. En este caso, también se tuvieron en cuenta los perfiles de pentosas y hexosas (Figura 7), aunque, de nuevo, el ajuste se centró en el TOC, siendo su error medio de un $33 \%$.

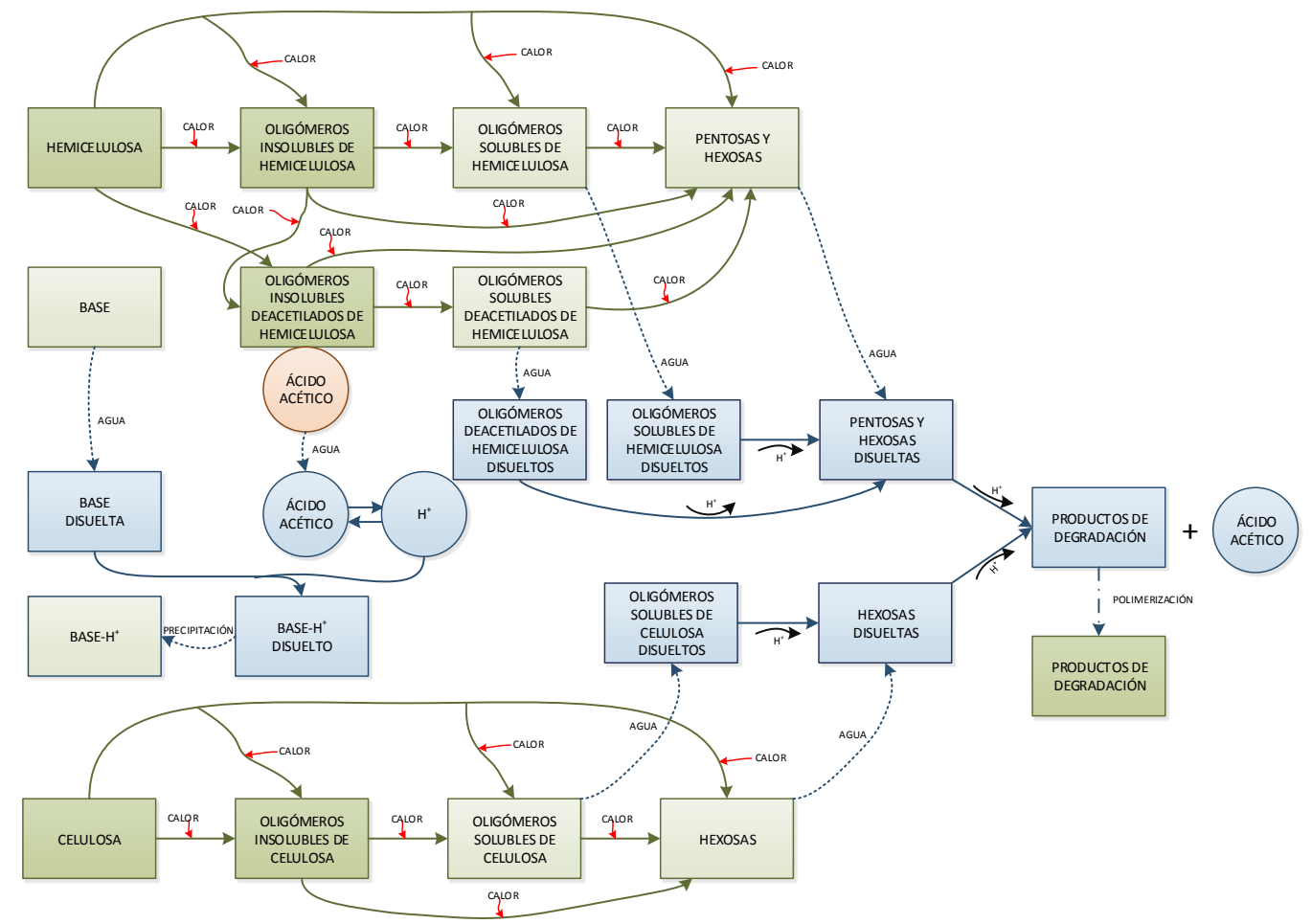

Figura 6. Mecanismo de reacción completo para el fraccionamiento hidrotermal de biomasa a condiciones subcríticas. 


\section{Resumen}
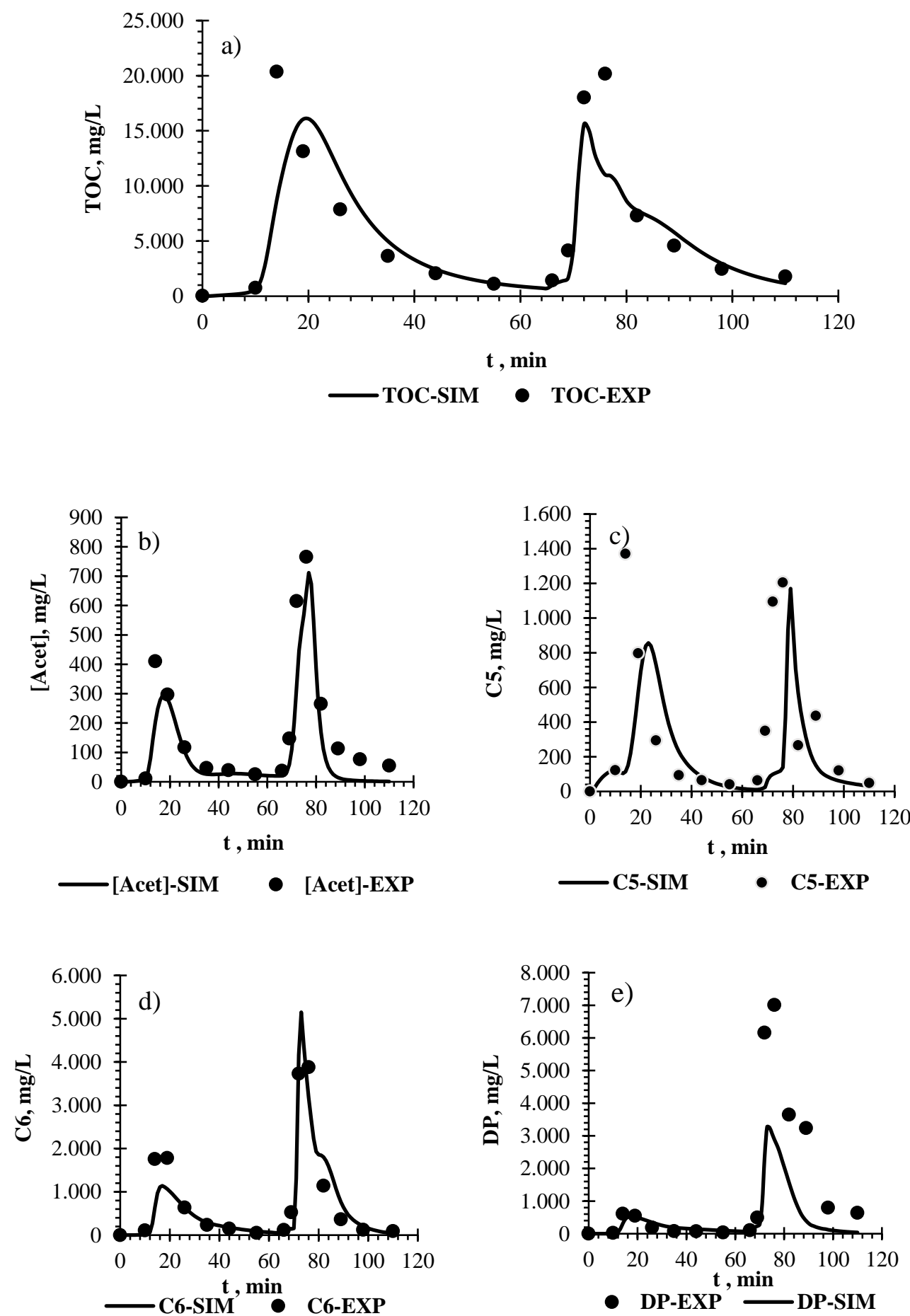

Figura 7. Ejemplo del ajuste de los perfiles de (a) TOC, (b) ácido acético, (c) pentosas-C5, (d) hexosas-C6 y (e) productos de degradación-DP utilizando el modelo poblacional del Capítulo 5. TOC-SIM: perfil de TOC simulado; TOC-EXP: perfil experimental del TOC; [Acet]-SIM: perfil simulado de la concentración de ácido acético; [Acet]-

EXP: perfil experimental de la concentración de ácido acético; C5-SIM: perfil simulado de la concentración de pentosas; C5-EXP: perfil experimental de la concentración de pentosas; C6-SIM: perfil simulado de la concentración de hexosas; C6-EXP: perfil experimental de la concentración de hexosas; DP-SIM: perfil simulado de los productos de degradación y DP-EXP: perfil experimental de los productos de degradación. 


\section{Resumen}

\section{Conclusiones}

La propuesta hecha en esta tesis para el modelado de la EFS es una alternativa basada en los tiempos característicos de la extracción, lo que simplifica el entendimiento del proceso. Además, el modelo desarrollado se resuelve mediante una interfaz basada en Excel, facilitando su uso por cualquier usuario. La validación del modelo se realizó mediante datos de dos materias primas cuya extracción está controlada por diferentes resistencias a la transferencia de materia. La primera biomasa utilizada fueron semillas de sésamo, en la que controla el equilibrio entre fases y la transferencia de materia externa. La segunda fueron granos de café, cuya extracción está limitada por la difusión interna. El equilibrio entre fase se simuló mediante una relación lineal (tipo Henry) y el error del modelo fue siempre menor a un $11 \%$.

En cuanto a la pirólisis de biomasa, el modelo cinético desarrollado pudo ser utilizado para analizar el efecto de distintas variables, como la velocidad de calentamiento o el tipo de atmosfera (inerte u oxidante). El mecanismo de reacción propuesto fue una modificación del mecanismo de Waterloo. Mecanismo que establece que toda substancia sólida en la materia prima puede descomponer en gases y un residuo solido carbonoso, el char. La modificación se centró en asumir que este residuo puede continuar degradando en más volátiles y en la inclusión de la evaporación de los posibles líquidos contenidos en la materia prima. En cuanto a las cinéticas utilizadas, fueron de tipo autocatalítico ya que la despolimerización de la biomasa se acelera una vez esta empieza. La validación se realizó con biomasas de un origen completamente distinto (residuos agrarios, maderas y fracciones puras: celulosa, hemicelulosa y lignina), siendo el error siempre menor a un 7 $\%$. Dicho modelo se resolvió utilizando otra interfaz basada en Excel.

Finalmente, el modelo para el FHT de biomasa que incluyó la simulación de los principales procesos involucrados. Dichos procesos son, esencialmente: la despolimerización de la biomasa, la extracción de los compuestos solubles, la producción de azucares y la variación del pH. Una vez más, se utilizaron cinéticas autocatalíticas ya que el proceso se auto-acelera una vez empieza. El estudio se centró en el fraccionamiento en reactores de lecho fijo a temperaturas alrededor de $180^{\circ} \mathrm{C}$ para favorecer la extracción de la hemicelulosa. Además, se analizó el efecto del caudal, el diámetro de partícula y la temperatura. De los tres, la temperatura resultó ser la principal variable. La validación se centró en la reproducción del perfil del contenido en carbono de la corriente a la salida del reactor y el error medio estuvo en torno a un $33 \%$. Por otro lado, este modelo fue 


\section{Resumen}

posteriormente modificado incluyendo poblaciones de oligómeros (de hasta 200 miembros) para una mejor simulación de la despolimerización. De igual modo, reacciones de repolimerización y de degradación de los azucares se tuvieron también en cuenta en esta segunda versión ya que la temperatura de operación llegó hasta los $280^{\circ} \mathrm{C}$.

A modo de resumen, puede concluirse que se han planteado y validado diversos modelos para la pirolisis, EFS y FHT de biomasa. Modelos que pudieron similar de forma satisfactoria el comportamiento experimental y el efecto de las principales variables operacionales. De igual modo, dichos modelos podrían ser utilizados para el estudio de dichas tecnologías (pirólisis, EFS y FHT) por un amplio espectro de usuarios, ya que su resolución se realiza mediante interfaces en Excel.

\section{Trabajo futuro}

En lo que se refiere al trabajo futuro, la idea queda recogida en el Apéndice 2. Lo que se pretende es generalizar y completar el modelo desarrollado en el Capítulo 4, de forma que se pueda utilizar para reproducir el comportamiento de distintas biomasas y en distintos reactores. Para ello, la siguiente metodología es propuesta:

- Ajuste de datos sobre el fraccionamiento hidrotermal de encina, paja de trigo y catalpa en reactores de volúmenes de 3,6 y $40 \mathrm{~L}$, realizando para ello las modificaciones pertinentes en el modelo y el mecanismo.

- Análisis de los parámetros obtenidos durante los ajustes, comparación entre sí y con los parámetros del Capítulo 4.

- Propuesta de correlaciones generales y similitudes entre las distintas biomasas

- Análisis de las limitaciones inherentes al modelo y propuestas de mejora.

Este trabajo está actualmente en desarrollo y se está haciendo en colaboración con el Instituto de Procesos Termales de Separación, de la universidad Técnica de Hamburgo. 
Resumen 
Chapter 1

CHAPTER 1 



\title{
Simulation of the supercritical $\mathrm{CO} 2$ extraction from natural matrices in packed bed columns: User-friendly simulator tool using Excel.
}

\author{
A.Cabeza ${ }^{a}$, F. Sobrón ${ }^{a}$, J. García-Serna ${ }^{a}$. M. J. Cocero ${ }^{a *}$
}

${ }^{a}$ High Pressure Processes Group, Department of Chemical Engineering and Environmental Tech., University of Valladolid, 47011 Valladolid, Spain *Corresponding author: micocero@iq.uva.es

DOI: $\underline{\text { https://doi.org/10.1016/j.supflu.2016.05.020 }}$

\begin{abstract}
The aim of this work was to develop a user-friendly Excel interface to adjust the yields of an extraction column. Moreover, this program could simulate the dynamic concentration profiles inside the column, being a useful teaching tool. The model comprises non-stationary mass balances for the recovered compounds in both phases (solid and supercritical $\mathrm{CO}_{2}$ ). The model was tested by reproducing the extraction of two samples: sesame seeds and coffee beans (average deviations of $7.41 \%$ and $10.35 \%$, respectively). These samples were selected to demonstrate the feasibility of reproducing processes whose mass transfer limitation is different. Thus, for the sesame seeds, the extraction process was controlled by both the external mass transfer and oil solubility, since the seeds were grinded. On the contrary, for coffee grains, the internal diffusion controls the extraction as the whole grain is required. Regarding solubility, a Henry's linear relation between solid and $\mathrm{CO}_{2}$ concentration was assumed.
\end{abstract}

Keywords: Supercritical $\mathrm{CO}_{2}$, Excel interface, oil extraction, decaffeination, modelling, natural matrixes. 


\section{Introduction}

Extraction of oil or other compounds from natural solid matrixes is a well-known process in industry. For decades, it has been successfully performed by organic solvents, generating an exhausted solid, which presents a residual amount of solvent, and a liquid rich in the extracted compound. This solid generally requires a purification to remove this organic residue (due to healthy or quality considerations) and the obtained liquid could also need another stage to recover the extracted substance. Therefore, the conventional solid-liquid extraction process always needs two stages: the extraction with the solvent and a purification with another material agent or energy. For this reason, other solvents has been considered, being supercritical fluids (SCF) the most extended option. Supercritical fluid extraction (SFE) would have two main advantages against the conventional method. The first would be that solubility in the SCF is totally controlled by pressure and temperature. So, the recovered compounds can be completely separated from the solvent only with a change in these variables. The second would be that as the solvent is a SCF, only with a depressurization the exhausted solid would be clean of residual solvent. The most common SCF for these extractions is $\mathrm{CO}_{2}$ because its critical point is relative low $\left(7.38 \mathrm{MPa}\right.$ and $\left.31.1^{\circ} \mathrm{C}\right)$ and because it is non-toxic and nonflammable (Henley \& Seader, 1981; Manivannan \& Sawan, 1998; Nahar \& Sarker, 2012).

This extraction of certain compounds from natural raw material with supercritical $\mathrm{CO}_{2}$ $\left(\mathrm{ScCO}_{2}\right)$ has been thoroughly studied and several articles can be found in literature (de Melo et al., 2014; Nerome et al.; Rai et al., 2016; Spinelli et al., 2016). Sara Spinelli et al. (Spinelli et al., 2016) studied the SFE with $\mathrm{CO}_{2}$ and ethanol as entrainer of phenolic compounds and flavonoids from brewer's spent grain (BSG). They analysed the effect of temperature, pressure and entrainer concentration, obtaining that $\mathrm{ScCO}_{2}$ with a $60 \%$ of ethanol archives yields of $0.35 \mathrm{mg} / \mathrm{g}$ BSG and $0.22 \mathrm{mg} / \mathrm{g}$ BSG for phenolic compounds and flavonoids, respectively. Amit Rai et al. (Rai et al., 2016) assessed the oil extraction from sunflower seeds varying temperature, pressure, particle diameter, flow rate and cosolvent or entrainer concentration (ethanol). Their result was that this extraction reach a yield of $54.37 \mathrm{wt} \%$ with a $5 \%$ of co-solvent. Hazuki Nerome et al. (Nerome et al.) performed a work about the extraction of pigments from Saffron (Crocus sativus L.) with $\mathrm{ScCO}_{2}$ and two co-solvents (water and methanol) obtaining higher yields than in the conventional process. Thus, $\mathrm{ScCO}_{2}$ has been used successfully to perform extractions of 


\section{Chapter 1}

herbs, seeds and grains and with high yields. Moreover, some SFE, such as coffee beans or green-tea decaffeination are already at industrial scale (Lack \& Seidlitz, 1993).

Regarding its modelling, there are also a lot of works about it (de Melo et al., 2014; Döker et al., 2010; Sovová, 1994). It is worth highlighting the work of H. Sovová (Sovová, 1994) who developed a model for $\mathrm{ScCO}_{2}$ extraction with 3 different solutions, depending on the mass transfer limitation. In the same way, Onur Döker et al. (Döker et al., 2010) studied the modelling of the SFE of oil from sesame seeds with $\mathrm{ScCO}_{2}$. They compared two options: Shrinking core model and Broken and intact cell model, obtaining that the first would be the best option to reproduce the extraction (deviations lower than $8.54 \%$ and $14.65 \%$ respectively). Similarly, B. Honarvar et al. (Honarvar et al., 2013) also assessed the modelling for the extraction of sesame seeds but comparing three different equilibrium relations: Henry's, Freundlich's and Brunauer, Emmet and Teller's. Their result was that the latter would be the most appropriate to reproduce the experimental yields (deviations of $9.84 \%, 7.42 \%$ and $5.28 \%$ respectively). However, all these previous studies are focused in the reproduction of the experimental data without further considerations. Therefore, they do not include the simulation of the extracted compound in both phases, which would be a key factor in order to understand how extraction is and how the operational variables affect it.

Thus, the aim of this work is to develop a user-friendly Excel interface to adjust the extraction yields and to simulate the dynamic concentration profiles inside the extraction column. This interface would be based on a model for SCE which would be validated for two of the most studied extraction process, e. g. oil extraction from seeds (sesame seeds) and coffee beans decaffeination. Moreover, this Excel program could be used to simulate the effect of particle dimeter, volumetric flow, pressure and temperature in the extraction.

\section{Extraction process and available data}

\subsection{Extraction process}

A typical configuration for a SFE process is shown in Figure 1. It consist of a gas bottle (T-01), a heat exchanger (H-01), a pump (P-01), the extraction column (E-01) and an expansion valve (V-01) and vessel (T-02). 


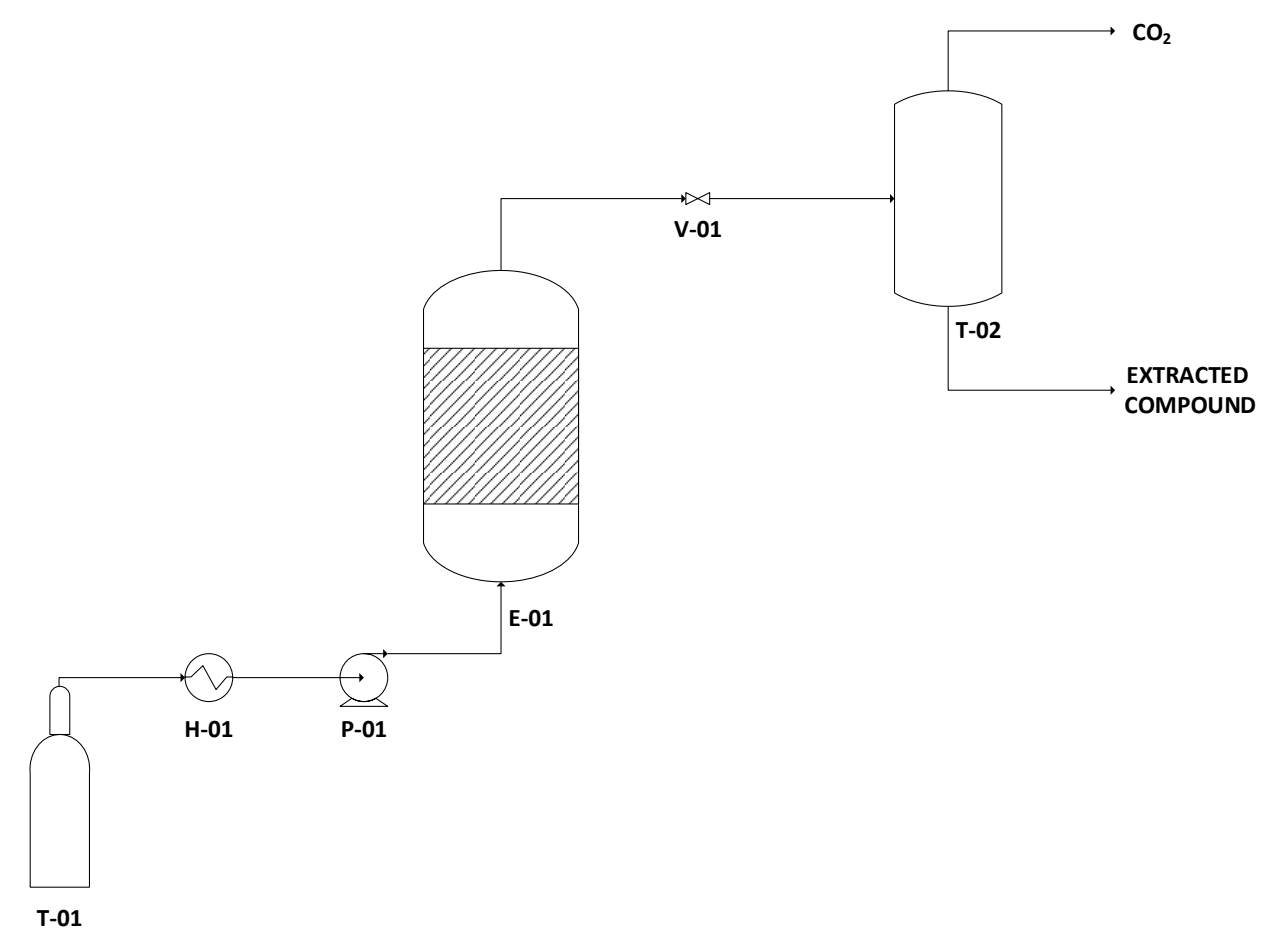

Figure 1. Process flow diagram of a typical SFE process with $\mathrm{CO}_{2}$. T-01: gas bottle, $\mathrm{H}-01$ : heat exchanger, P-01: pump, E-01: extraction column, V-01: expansion valve and T-02: expansion vessel.

The operation starts with the conditioning of the stream from the bottle T-01 in the heat exchanger H-01 and in the pump P-01. This stage is done in order to transform the gas into a SCF at the desired operational conditions. Once this stream is already a SCF, it is fed to the extraction column E-01 to separate the desired compound from the solid matrix. Therefore, the output stream of the column E-01 is composed of the SCF and the desired compound. Finally, it is expanded in the valve V-01 to separate the extracted compound from the solvent in $\mathrm{T}-02$ by the transformation of the SCF into a gas due to this pressure change.

\subsection{Available data and raw materials}

As it as mentioned in section 1, the raw materials assessed in this work are sesame seeds and coffee grains, which were selected for two reasons. The first is that they are examples of the most studied SFE process: oil recovering and decaffeination. On the other hand, the second is related with mass transfer limitations. Generally, in an oil extraction seeds are previously milled whereas, in a coffee grain decaffeination, grains are not physically pre-treated. Therefore, in the former several stages with a different mass transfer control are expected (Figure 2-b) and the effect of temperature, pressure, volumetric flow and 


\section{Chapter 1}

particle diameter can be considered. On the contrary, in coffee grains only one stage is awaited and particle diameter cannot be taken into account since they are not milled.

The data from the oil extraction from sesame seeds were taken from Onur Döker et al. (Döker et al., 2010), who treated samples of $4 \mathrm{~g}$ (56 \% of oil) with $\mathrm{ScCO}_{2}$. For caffeine extraction, the data were found in Hulya Peker et al. (Peker, 1992), who worked with $0.86 \mathrm{~g}$ of coffee with a content of $3.8 \%$ of caffeine and humidified $\mathrm{ScCO}_{2}$. The whole set of experiments and their operational conditions are listed in Table 1.

Table 1. Studied experiments and their operational conditions.

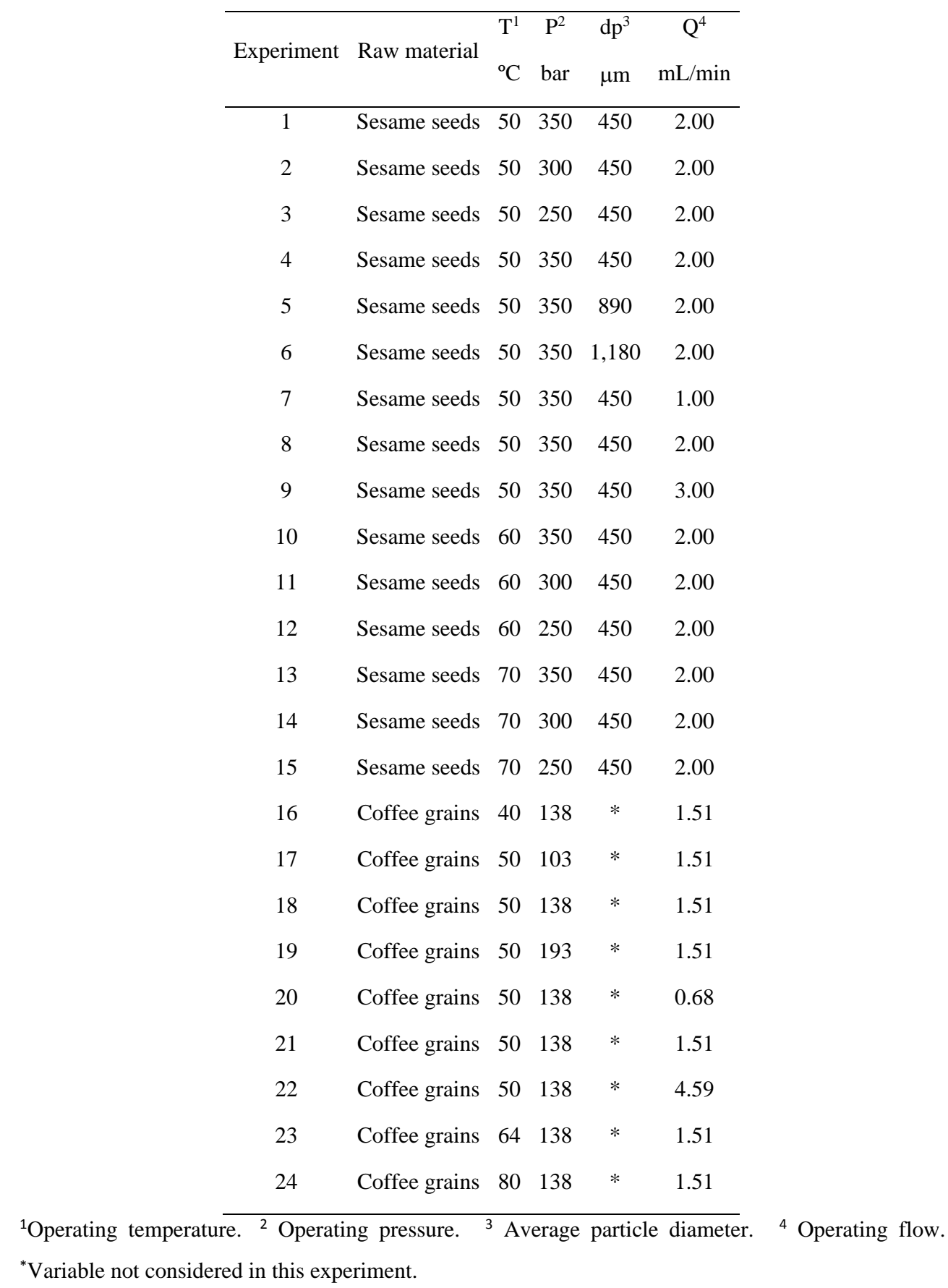




\section{Extraction theory}

\subsection{Mass transfer during a extraction from a solid raw material}

In Figure 2-a all the steps involved in an extraction process are shown. First, the desired compound should be solved by the SCF (step 1). Then, it diffuses (step 2) in the pores of the raw material up to reach the solid external surface. Finally, it should go through the boundary layer (step 3) of the SCF in order to be extracted from the solid. The relative value between these steps affect strongly to the extraction, as can be seen in Figure 2-b.

In Figure 2-b an extraction curve (yield vs time) with three different stages (A, B and C) is showed. Stage A corresponds to a fast extraction process, which means an extraction with no internal diffusion effect (step 2 in Figure 2-a). This stage can take place if the material has been previously milled or if the extraction is performed in the external surface of the solid. On the other hand, stage B is related with a process in which the external transport and the internal diffusion have similar values or with low solubility. The former can occur when low internal diffusion exits, therefore when the compound solves near the external solid surface. Finally, stage $\mathrm{C}$ takes place when internal diffusion controls the extraction, which means that the solubilisation is done far from the external solid surface.
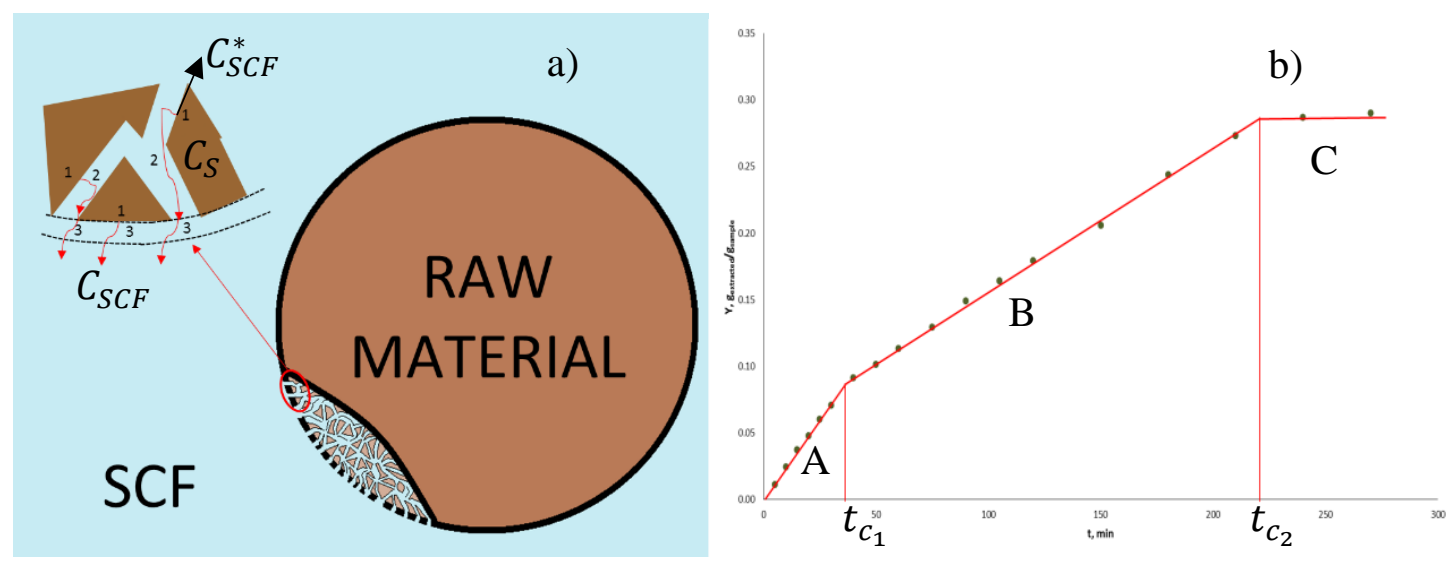

Figure 2. Mass transfer steps during an extraction (a) and their effect in the extraction curve (b). 1: solubilisation, 2 : internal diffusion of the extracted compound and 3: external mass transfer of the extracted compound. A: extraction controlled by the external transport, B: extraction controlled by both: external transport and internal diffusion and C: extraction controlled by internal diffusion. 


\subsection{Solubility in SCF}

SCFs have transport properties between liquids and gases, such as densities similar to liquids and diffusivities closer to gases (Manivannan \& Sawan, 1998; Nahar \& Sarker, 2012). Moreover, changes in the dielectrical properties are also observed. For example, water presents an enormous change in its dielectric constant (Kritzer et al., 1999) when pressure and temperature are increased. This change is so big that supercritical water cannot solve polar substances (Figure 3).

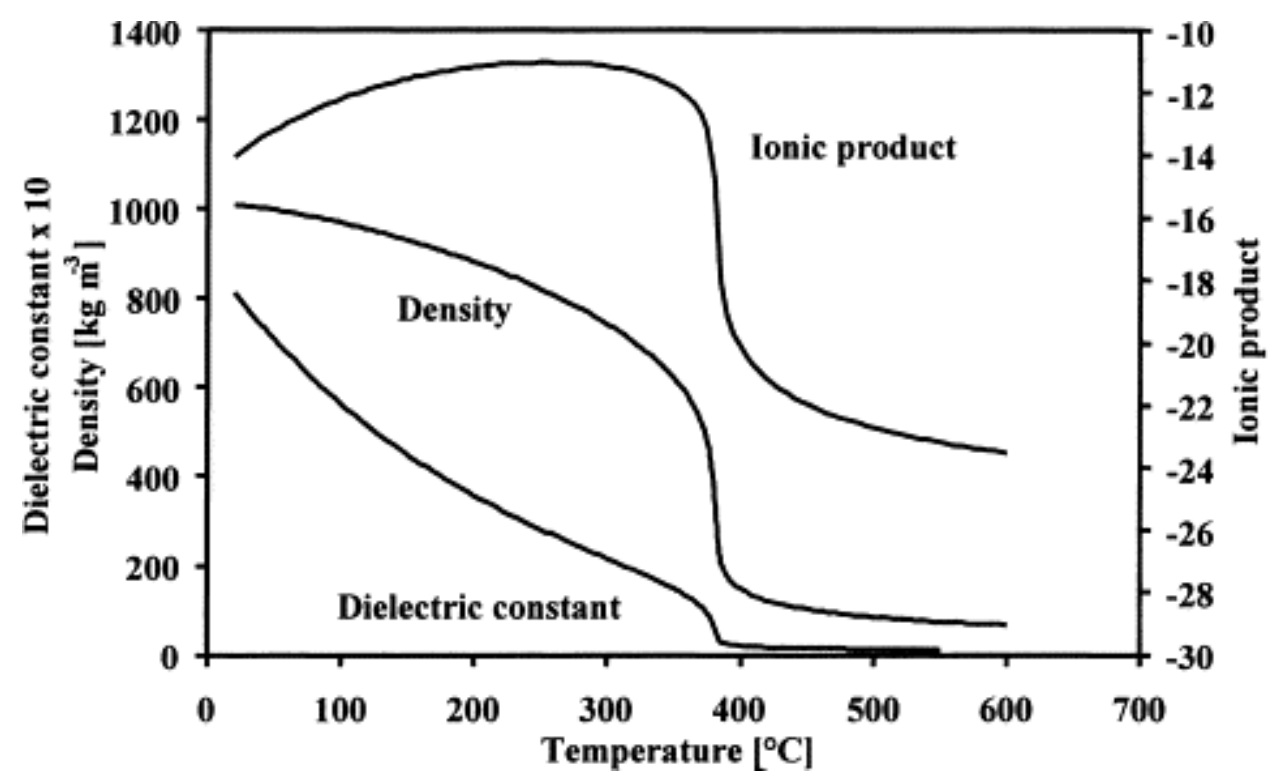

Figure 3. Dielectric properties changes in water with temperature at $24 \mathrm{MPa}$ (Kritzer et al., 1999).

On the other hand, temperature and pressure also affect density, which enhances solving properties. This relation of the solubility with the SCF density can be observed in Eq. ( 1 ), where the Hildebrand's solubility parameter $(\delta)$ is calculated by the critical pressure $\left(\mathrm{P}_{c}\right)$ and the density of the SCF $(\rho)$. Therefore, it is confirmed that solubility in SCFs is totally controlled by temperature and pressure (as it was mentioned in section 1) (Nahar \& Sarker, 2012).

$$
\delta=0.47 \cdot P_{c}^{1 / 2} \cdot \rho
$$

\subsubsection{Co-solvents}

Although solubility in SCF is easily controllable, it also has some restrictions. For instance, $\mathrm{ScCO}_{2}$ has a low polarity (Dobbs et al., 1986; Nerome et al.), which means that its efficiency to extract polar compounds is low. Therefore, in order to increase its solvent 
capacity, a small amount of a polar substance (co-solvent) is added to the SCF. Some typical examples of co-solvents are: ethanol, methanol and water.

\subsection{Model}

The model of the process was done applying a non-stationary mass balance for the recovered compound in both phases. In order to simplify the modelling, it was assumed that (1) the bed porosity remains constant, that (2) there are no diffusional transport along the length of the column and that (3) the solubilisation follows a Henry's relation. The balance for the SCF is shown in Eq. ( 2 ) and for the solid in Eq. ( 3 ).

$$
\begin{gathered}
\frac{\partial C_{S C F}}{\partial t}=\frac{1}{\varepsilon} \cdot\left[-\frac{u}{L} \cdot \frac{\partial C_{S C F}}{\partial z}+K \cdot a \cdot\left(C_{S C F}^{*}-C_{S C F}\right)\right] \\
\frac{d C_{s}}{d t}=\frac{1}{1-\varepsilon} \cdot\left[-K \cdot a \cdot\left(C_{S C F}^{*}-C_{S C F}\right)\right]
\end{gathered}
$$

Where $C_{S C F}^{*}$ corresponds to the equilibrium concentration of the extracted compound in the SCF calculated by a Henry's relation with the concentration in the solid $\left(C_{s}\right)$ : $C_{S C F}^{*}=H \cdot C_{S}$.

Regarding the mass transfer between both phases, a global coefficient from the equilibrium concentration and the concentration in the SCF phase was used. In order to include the three possible stages defined in section 3.1, it was defined as a function of the times (Eq. ( 4 )) when the change between these stages takes places (Figure 2-b).

$$
K \cdot a=\frac{k_{S C F} \cdot a_{S C F} \cdot\left(\frac{F}{1+e^{-\left(t-t_{c_{1}}\right)}}\right)}{1+e^{\left(t-t_{c_{2}}\right)}}+\frac{k_{s} \cdot a_{s}}{1+e^{-\left(t-t_{c_{2}}\right)}}
$$

Where $F$ is a correction factor in order to include the stage $\mathrm{B}$.

These times of change between stages would be the breaking times and they would be a reverse function of the mass easy to extract. Thus, $t_{c 1}$ would be a function of that mass whose extraction would be controlled by a short internal diffusion and external mas transport. And $t_{\mathrm{c} 2}$ would be related with an extraction dominated by external transport. 


\subsubsection{Resolution}

The model formed by Eq. ( 2 ) and ( 3 ) constitutes a set of partial differential equations. This set was discretised by the orthogonal collocation on finite elements method, obtaining a set of ordinary differential equations. The latter was solved by the RungeKutta's method with $8^{\text {th }}$ order of convergence (Press et al., 2007).

On the other hand, the optimization problem related with the adjustment of the experimental extraction curves was solved by two methods. The first was the SimplexNelder-Mead's method to obtain an initial solution of the problem. Finally, this solution was re-optimized applying the Broyden-Fletcher-Goldfarb-Shanno's method. The objective function was the Absolute Average Deviation (A.A.D.) between the simulated and experimental yields (Eq. ( 5 )).

$$
\text { A.A.D. }=\sum_{i=1}^{n} \frac{1}{n} \cdot \frac{\left|x_{i_{E X P}}-x_{i_{S I M}}\right|}{x_{i_{E X P}}} \cdot 100
$$

\section{Results and discussion}

\subsection{Pressure and temperature effect: solubility changes}

From Figure 4 the effect of temperature and pressure can be observed. Figure 4-a and $b$ show the evolution of the extraction yield for oil from sesame seeds and caffeine from coffee beans, respectively. It can be observed that, for both processes, the yield increases with pressure. This behaviour agrees with the discussion in section 3.2 since density rises with pressure (from $834 \mathrm{~kg} / \mathrm{m}^{3}$ at $50{ }^{\circ} \mathrm{C}$ and 250 bar up to $899 \mathrm{~kg} / \mathrm{m}^{3}$ at $50{ }^{\circ} \mathrm{C}$ and 350 bar). So, solubility also should grow with pressure.

On the other hand, in Figure 4-b and $\mathrm{c}$ the role of temperature in oil extraction and coffee beans decaffeination is shown, respectively. For oil extraction, a decrement in the yield can be observed due to the reduction of density (and solubility) with temperature (from $834 \mathrm{~kg} / \mathrm{m}^{3}$ at $50{ }^{\circ} \mathrm{C}$ and 250 bar up to $737 \mathrm{~kg} / \mathrm{m}^{3}$ at $70{ }^{\circ} \mathrm{C}$ and 250 bar). Behaviour that also agrees with section 3.2. Moreover, it is remarkable that at 250 bar and $70{ }^{\circ} \mathrm{C}$ the stage B appears because of the low solubility (see section 3.1). However, for the decaffeination an increment in the yield was observed, although density decreased with temperature. This deviation from the expected evolution can be explained by the co-solvent (Peker, 1992). As the operation is performed by a mixture of $\mathrm{ScCO}_{2}$ and water, there will be a partition coefficient of caffeine between the two phases. This coefficient is defined as the 
ratio of the caffeine concentration in the SCF and its equilibrium concentration in water, which has been found that increases with temperature at high pressures.
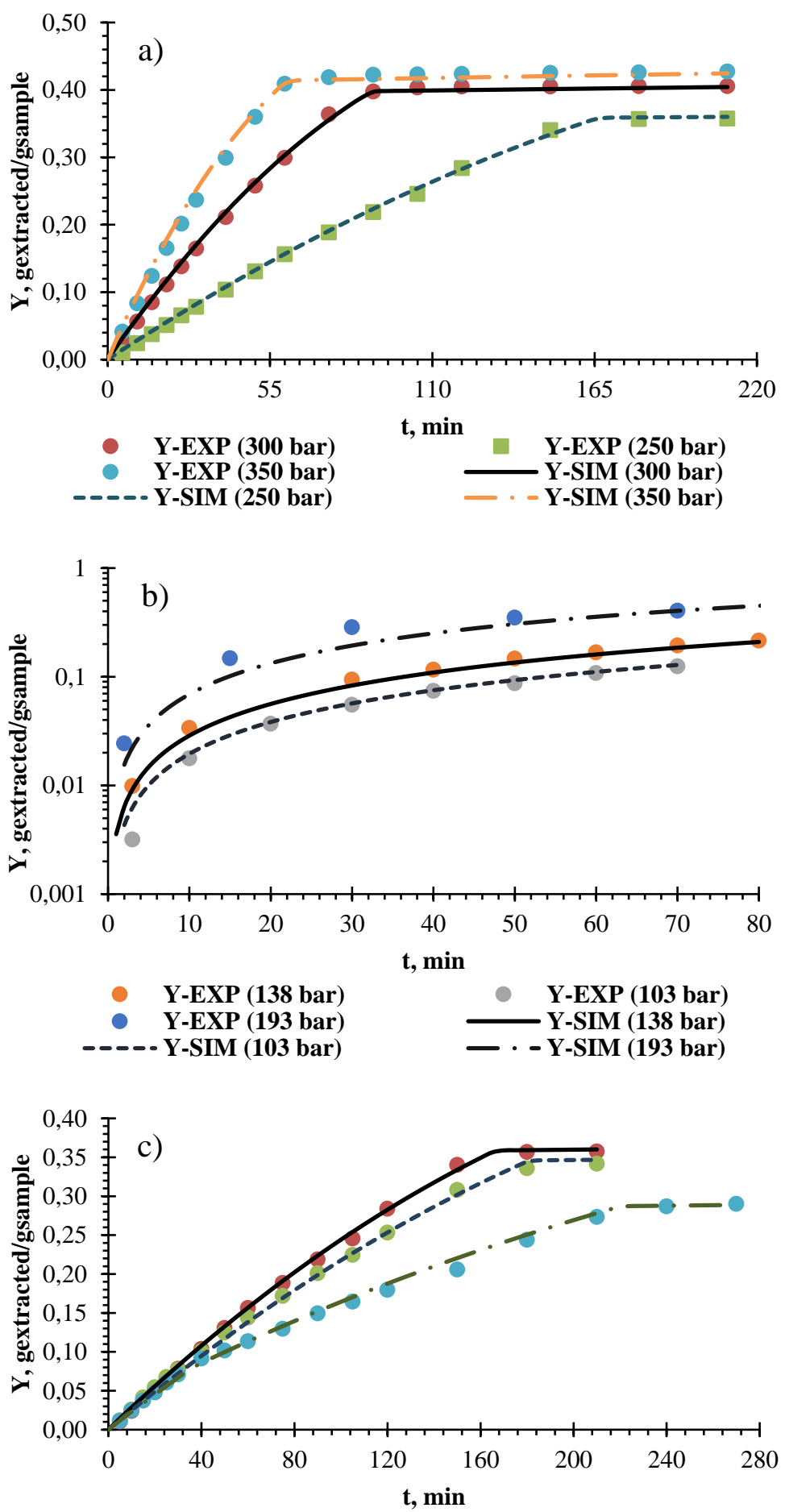

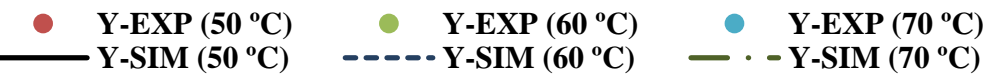




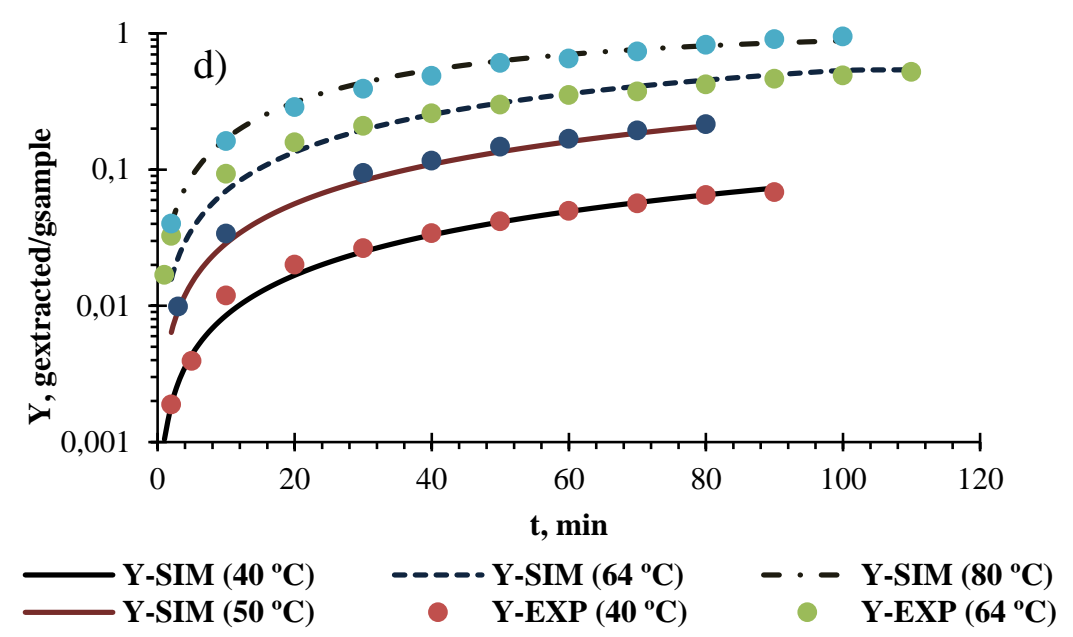

Figure 4. Effect of the operating temperature and pressure in a SCF extraction. (a) Effect of the operating pressure in the oil extraction from sesame seeds at $50^{\circ} \mathrm{C}, 2.00 \mathrm{~mL} / \mathrm{min}$ and $450 \mu \mathrm{m}$. (b) Effect of the operating pressure in the caffeine extraction from coffee beans at $50{ }^{\circ} \mathrm{C}$ and $1.51 \mathrm{~mL} / \mathrm{min}$. (c) Effect of the operating temperature in the oil extraction from sesame seeds at $250 \mathrm{bar}, 2.00 \mathrm{~mL} / \mathrm{min}$ and $450 \mu \mathrm{m}$. (d) Effect of the operating temperature in the caffeine extraction from coffee beans at $138 \mathrm{bar}$ and $1.51 \mathrm{~mL} / \mathrm{min}$. Y-SIM: simulated extraction yield ( $\left.\mathrm{g}_{\text {extracted }} / \mathrm{g}_{\text {sample}}\right)$. Y-EXP: experimental extraction yield ( $\left.\mathrm{g}_{\text {extracted }} / \mathrm{g}_{\text {sample }}\right)$.

\subsection{Particle diameter and flow effect: mass transfer changes}

In Figure 5- $a$ and $b$ the variation in the extraction yield with the volumetric flow is shown for a caffeine and oil extraction process, respectively. In both cases, the yield increases with flow since mass transfer is enhanced. However, there is a significant difference between them. In the oil extraction, all the curves tends to a similar value of yield, which means that the improvement in mass transfer only makes faster the process. While in decaffeination the yield is also increased. This discrepancy would be related with the fact that in oil extraction the seeds has been previously milled and a certain amount of oil is free to be recovered. In contrast, in decaffeination the extraction is performed to the whole grain and there is a real mass transfer limitation in the boundary layer (see section 3.1). Regarding the particle diameter, its effect in the oil recovering is shown in Figure 5-c, where it can be checked that the lower de particle diameter is, the greater extraction is obtained. This dependence is related with its effect in the external and internal mass transfer. So, a low diameter means more exchange surface, which enhances the external mass transfer, and less way to diffuse inside the solid. 

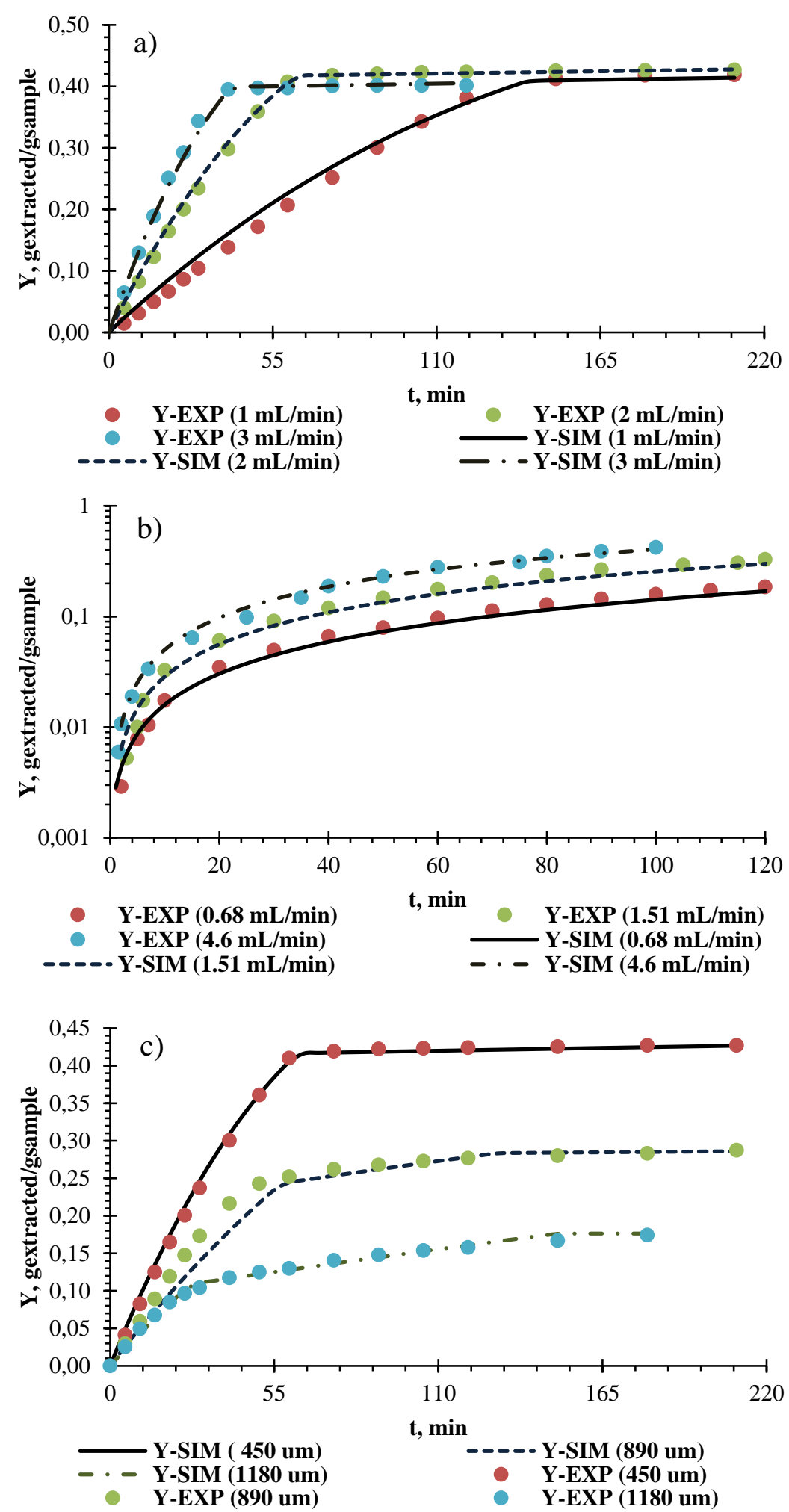

Figure 5: Particle diameter and volumetric flow effects. (a) Role of the volumetric flow in the oil extraction from sesame seeds at $50{ }^{\circ} \mathrm{C}, 350$ bar and $450 \mu \mathrm{m}$. (b) Role of the volumetric flow in the oil caffeine from coffee beans at $50{ }^{\circ} \mathrm{C}$ and 138 bar. (c) Role of the particle diameter in the oil extraction from sesame seeds at $50{ }^{\circ} \mathrm{C}, 350$ bar and 2.00 $\mathrm{mL} / \mathrm{min}$. Y-SIM: simulated extraction yield ( $\left.\mathrm{g}_{\text {extracted }} / \mathrm{g}_{\text {sample }}\right)$. Y-EXP: experimental extraction yield $\left(\mathrm{g}_{\text {extracted }} / \mathrm{g}_{\text {sample}}\right)$. 


\section{Chapter 1}

\subsection{Fittings}

In Figure 4 and Figure 5 the simulated behaviour with the model is shown and the A.A.D. of all the adjustments is arrayed in Table 2. In this table, it can be seen that the average deviation for sesame oil extraction and decaffeination were $7.41 \%$ and $10.35 \%$, respectively. The fact that the deviation was greater in decaffeination was expected since it was performed with a co-solvent and its effect was not taken into account separately in the model. All in all, all the deviations are relatively low and it can be checked that the simulation agrees with the experimental data. So, it can be concluded that the approach developed in section 3.3 can reproduce the experimental yields, including the effect of all the operational variables. The fitted parameters as long as their regression coefficients are listed from Table 3 to Table 7.

Table 2. A.A.D. of the adjustments.

\begin{tabular}{|c|c|}
\hline Experiment & $\begin{array}{c}\text { A.A.D. } \\
\%\end{array}$ \\
\hline 1 & 6.89 \\
\hline 2 & 3.62 \\
\hline 3 & 8.90 \\
\hline 4 & 6.62 \\
\hline 5 & 10.54 \\
\hline 6 & 4.49 \\
\hline 7 & 16.94 \\
\hline 8 & 6.32 \\
\hline 9 & 6.29 \\
\hline 10 & 7.14 \\
\hline 11 & 3.48 \\
\hline 12 & 4.95 \\
\hline 13 & 9.49 \\
\hline 14 & 8.93 \\
\hline 15 & 6.68 \\
\hline 16 & 7.82 \\
\hline 17 & 6.75 \\
\hline 18 & 7.75 \\
\hline 19 & 18.89 \\
\hline 20 & 10.09 \\
\hline 21 & 14.61 \\
\hline 22 & 6.68 \\
\hline 23 & 15.17 \\
\hline 24 & 5.38 \\
\hline Average Seeds & 7.41 \\
\hline Average Beans & 10.35 \\
\hline
\end{tabular}




\section{Chapter 1}

\subsubsection{Equilibrium constant}

In Table 3 and Figure 6-a the calculated values of the equilibrium constant and its regression coefficient for sesame oil are shown. In the same way, in Table 4 and Figure 7-a for caffeine. For sesame oil, it can be checked that its behaviour agrees with the theory showed in section 3.2. So, an increment in temperature generated a lineal decrement in density (Figure 6-b) and a lineal diminution of the solubility. However, for caffeine there is a discrepancy. In Figure 7-b, it can be seen that density decreases logarithmically with temperature but the solubility grows exponentially (Figure 7-a). In parallel, solubility is also increased exponentially with pressure (Figure 7-c) though density tends to a maximum (Figure 7-d). This deviation could be related again with the fact that water is used as a co-solvent and, at the operating conditions, and increment in temperature and pressure would enhance the solubility and the extraction (section 4.1).

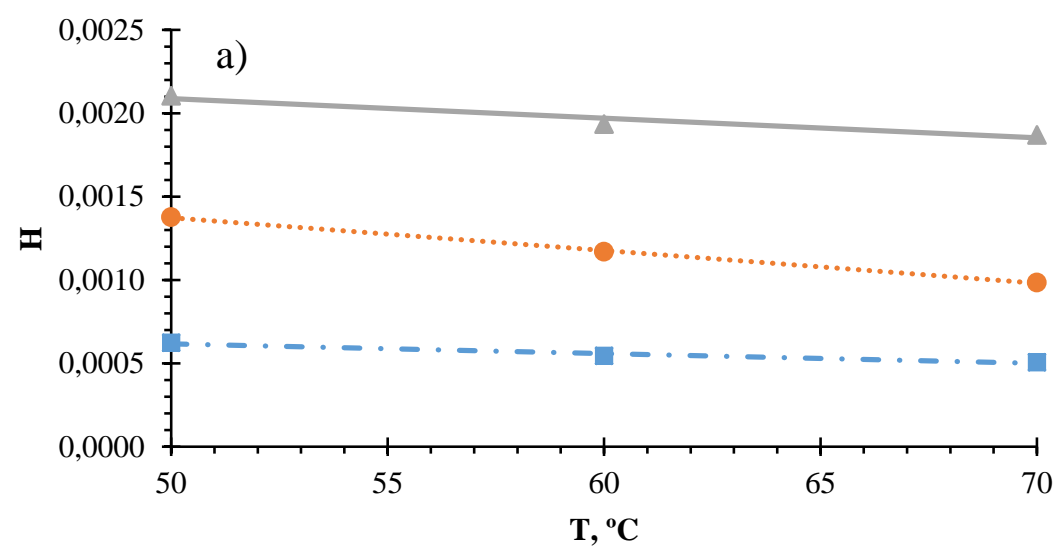

- $\mathbf{P}=250$ bar $\quad \quad \mathbf{P}=300$ bar $\quad \triangle P=30$ bar

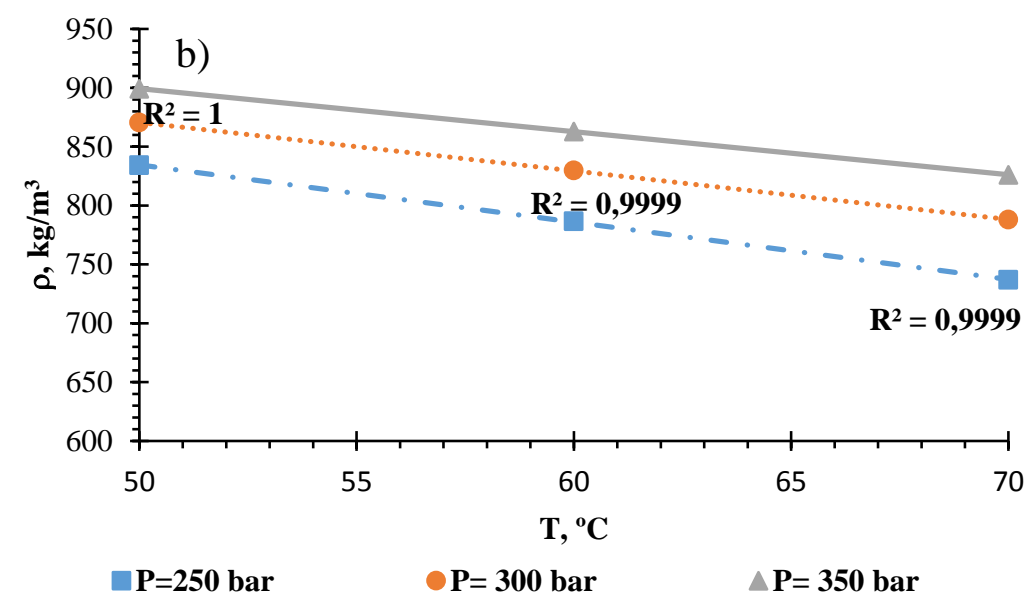

Figure 6. Sesame oil equilibrium constant evolution with temperature and pressure (a) and changes in $\mathrm{ScCO}_{2}$ with temperature and pressure. 


\section{Chapter 1}

Table 3. Fitted sesame oil equilibrium constant.

\begin{tabular}{cccc}
\hline \multicolumn{4}{c}{$\mathrm{H}$ (dimensionless) } \\
\hline $\mathrm{T}\left({ }^{\circ} \mathrm{C}\right)$ & 250 & 300 & 350 \\
& $\mathrm{P}(\mathrm{bar})$ \\
50 & $6.24 \mathrm{E}-04$ & $1.38 \mathrm{E}-03$ & $2.11 \mathrm{E}-03$ \\
60 & $5.45 \mathrm{E}-04$ & $1.17 \mathrm{E}-03$ & $1.94 \mathrm{E}-03$ \\
70 & $5.07 \mathrm{E}-04$ & $9.84 \mathrm{E}-04$ & $1.87 \mathrm{E}-03$ \\
\hline $\mathrm{R}^{2}$ & 0.96 & 0.999 & 0.94 \\
\hline
\end{tabular}

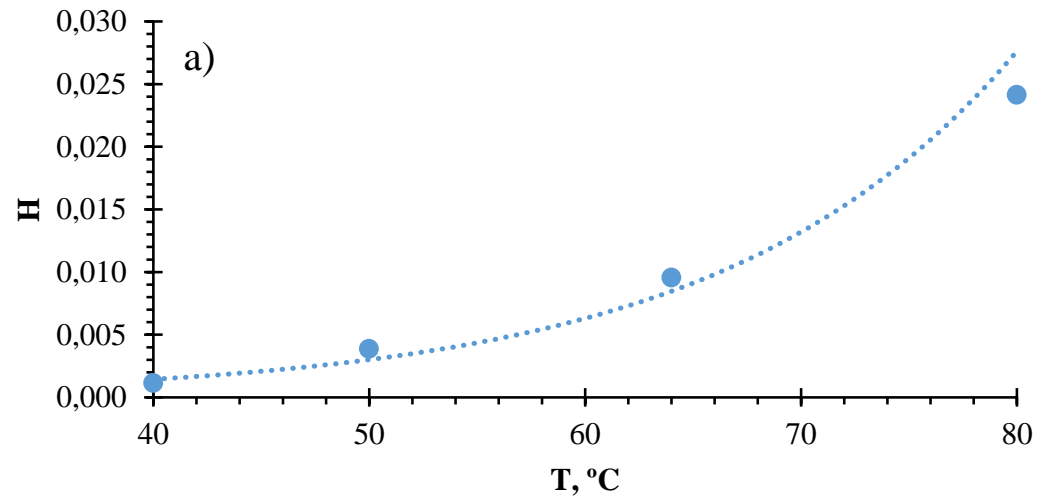

H (138 bar)

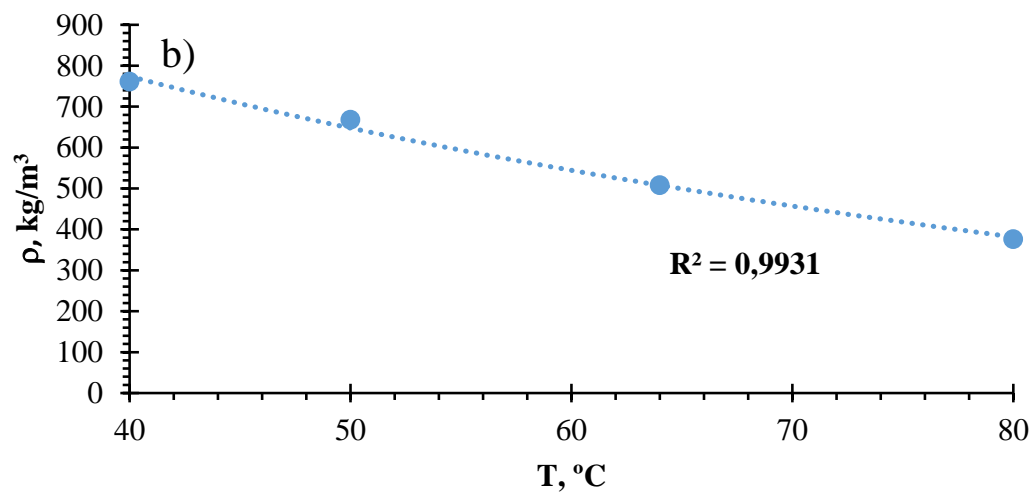

Density (138 bar) 


\section{Chapter 1}
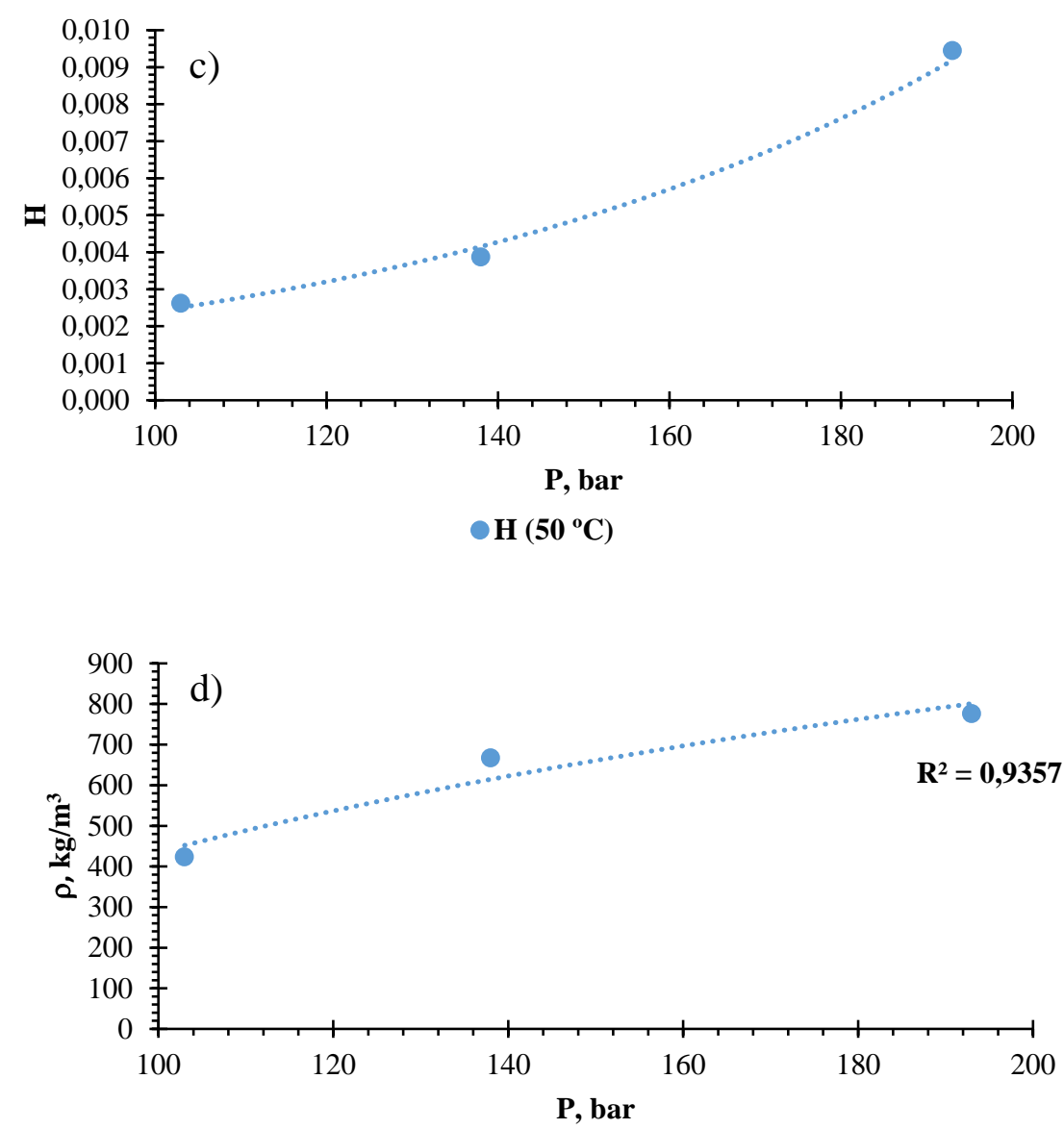

Density $\left(50^{\circ} \mathrm{C}\right)$

Figure 7. Caffeine equilibrium constant evolution with temperature (a) and pressure (c) and changes in $\mathrm{ScCO}_{2}$ density with temperature (b) and pressure (d).

Table 4. Fitted caffeine equilibrium constant.

\begin{tabular}{cccc}
\hline \multicolumn{4}{c}{$\mathrm{H}$ (dimensionless) } \\
\hline $\mathrm{T}\left({ }^{\circ} \mathrm{C}\right)$ & $\mathrm{P}(\mathrm{bar})$ \\
40 & $1.14 \mathrm{E}-03$ & 103 & $2.62 \mathrm{E}-03$ \\
50 & $3.87 \mathrm{E}-03$ & 138 & $3.87 \mathrm{E}-03$ \\
64 & $9.56 \mathrm{E}-03$ & 193 & $9.44 \mathrm{E}-03$ \\
80 & $2.41 \mathrm{E}-02$ \\
\hline $\mathrm{R}^{2}$ & 0.97 & \\
\hline
\end{tabular}




\section{Chapter 1}

\subsubsection{Mass transfer coefficient}

The external and internal mass transfer coefficients for sesame oil are showed in Figure 8 and Table 5. The obtained evolution with the flow and particle diameter was the expected result for both coefficients. Therefore, the external coefficients grow with the former and decreases with the latter. Regarding the internal coefficient, it was independent from the flow and it decreases with particle diameter. In addition, the correction factor for stage B (F) is also listed in Table 5. Its behaviour was also the awaited result, decreasing with pressure and particle diameter.
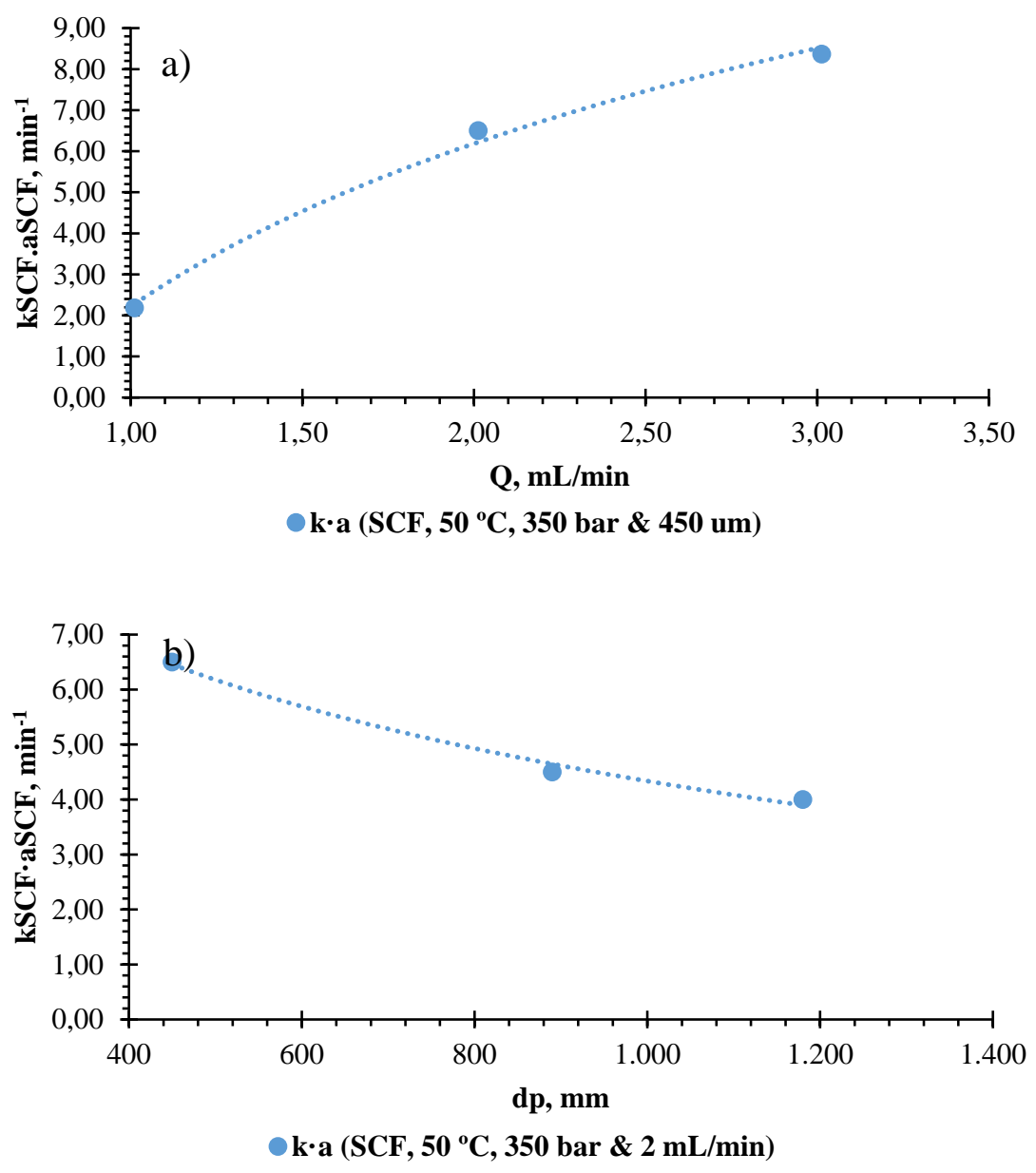


\section{Chapter 1}

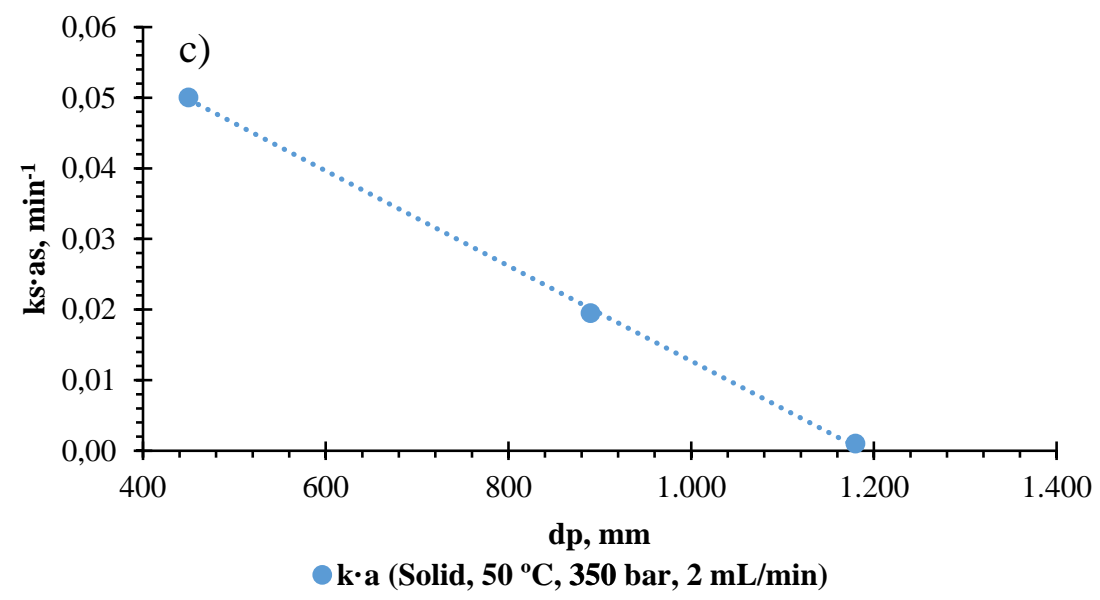

Figure 8. Sesame oil external mass transfer dependency with flow (a) and particle diameter (b) and internal mass transfer evolution with particle diameter (c).

Table 5. Fitted sesame oil external and internal mass transfer coefficients, including the correction factor (F) for stage B.

\begin{tabular}{|c|c|c|c|}
\hline \multicolumn{2}{|c|}{$\mathrm{k}_{\mathrm{s}} \cdot \mathrm{a}_{\mathrm{s}}\left(\min ^{-1}\right)$} & \multicolumn{2}{|c|}{$\mathrm{k}_{\mathrm{SCF}} \cdot \operatorname{ascF}\left(\mathrm{min}^{-1}\right)$} \\
\hline $\mathrm{d}_{\mathrm{p}}(\mu \mathrm{m})$ & & $\mathrm{dp}(\mu \mathrm{m})$ & \\
\hline 450 & $5.00 \mathrm{E}-02$ & 450 & 6.5 \\
\hline 890 & $1.95 \mathrm{E}-02$ & 890 & 4.5 \\
\hline 1180 & $1.00 \mathrm{E}-03$ & 1,180 & 4.0 \\
\hline $\mathrm{R}^{2}$ & 0.95 & & 0.95 \\
\hline \multicolumn{4}{|c|}{$\operatorname{ksCF} \cdot \operatorname{ascF}\left(\min ^{-1}\right)$} \\
\hline \multicolumn{4}{|c|}{$\mathrm{Q}(\mathrm{mL} / \mathrm{min})$} \\
\hline 1.00 & \multicolumn{3}{|c|}{2.18} \\
\hline 2.00 & \multicolumn{3}{|c|}{6.50} \\
\hline 3.00 & \multicolumn{3}{|c|}{8.36} \\
\hline $\mathrm{R}^{2}$ & \multicolumn{3}{|c|}{0.9995} \\
\hline \multicolumn{4}{|c|}{ F (dimensionless) } \\
\hline $\mathrm{P}$ (bar) & \multicolumn{3}{|c|}{$\mathrm{dp}(\mu \mathrm{m})$} \\
\hline 300 & 0.68 & 590 & 0.08 \\
\hline 250 & 0.32 & 1,180 & 0.07 \\
\hline
\end{tabular}




\section{Chapter 1}

On the other hand, for caffeine the global mass transfer coefficient was calculated (Table 6 and Figure 9) because during its extraction only the stage B was observed. So, the fact that its evolution with flow tends to a maximum would be correct since flow only enhances the external mass transfer.

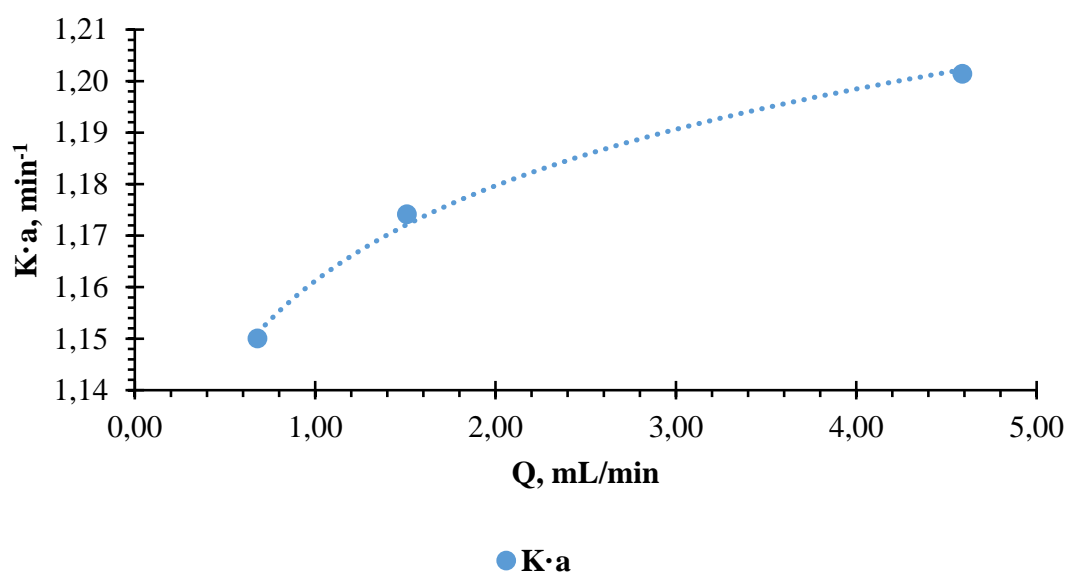

Figure 9. Caffeine global mass transfer coefficient dependency with flow.

Table 6. Fitted global mass transfer coefficient for caffeine.

\begin{tabular}{cc}
\hline \multicolumn{2}{c}{$\mathrm{K} \cdot \mathrm{a}\left(\mathrm{min}^{-1}\right)$} \\
\hline $\mathrm{Q}(\mathrm{mL} / \mathrm{min})$ & \\
0.68 & 1.15 \\
1.51 & 1.17 \\
4.59 & 1.20 \\
\hline $\mathrm{R}^{2}$ & 0.995 \\
\hline
\end{tabular}

\subsubsection{Breaking times}

The calculated values for the braking times $\left(t_{c 1}\right.$ and $\left.t_{c 2}\right)$ are shown in Figure 10 and Table 7. As it was mentioned in section 3.1, the parameters would be a reverse function of mass able to be extracted. Therefore, they should decrease with pressure and flow and increase with temperature and particle diameter, tending to a minimum and maximum value, respectively. Being this behaviour the obtained during the optimization. 


\section{Chapter 1}

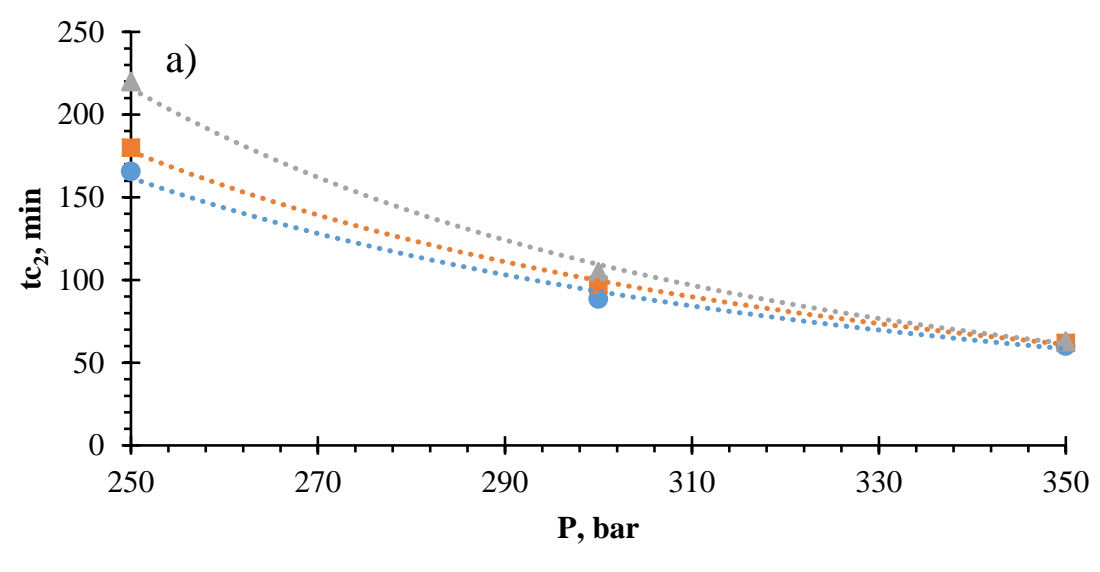

$\mathrm{T}=50^{\circ} \mathrm{C} \quad \mathrm{T}=60^{\circ} \mathrm{C} \quad \mathrm{T}=70^{\circ} \mathrm{C}$
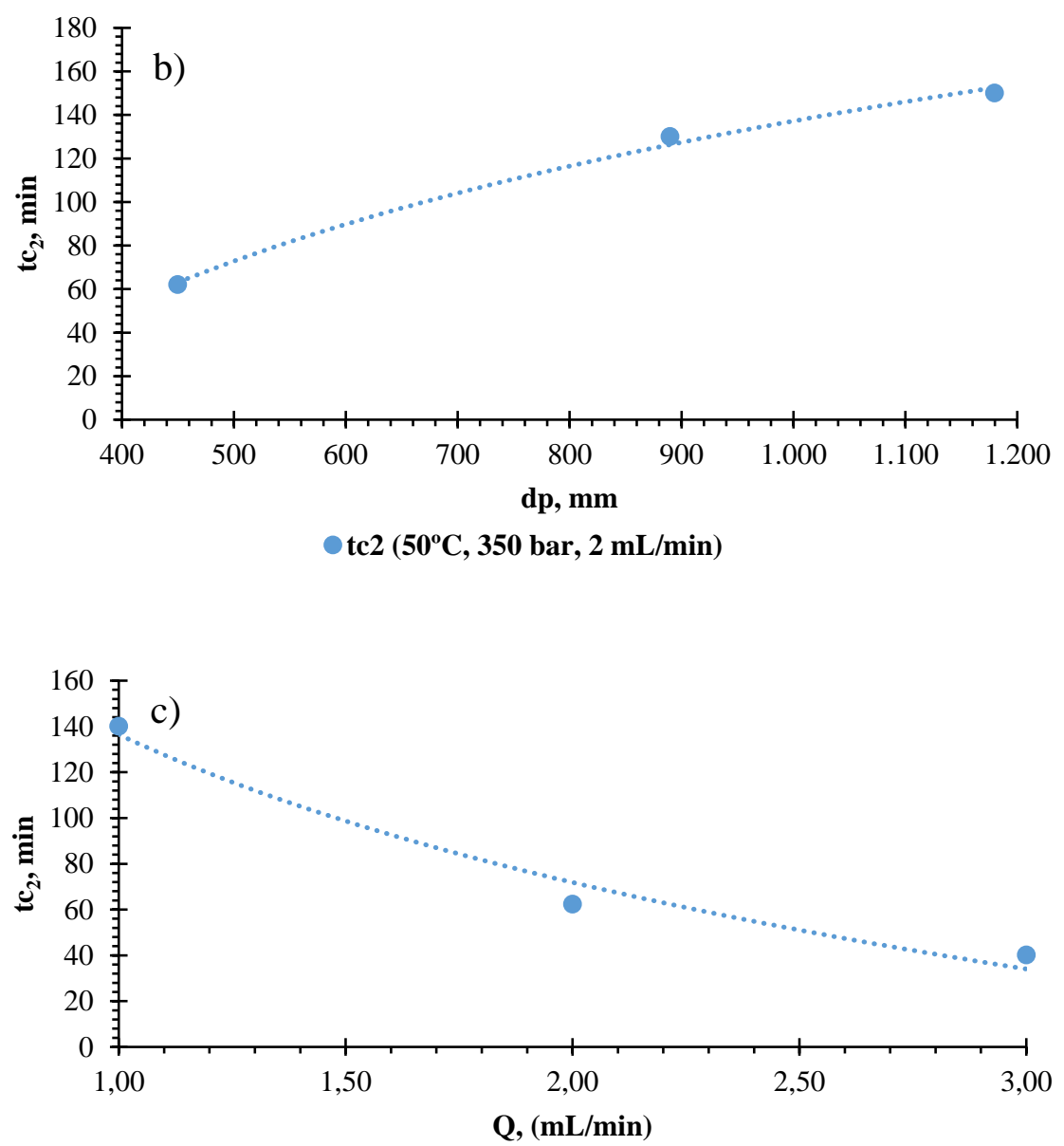

tc2 (450 um, $50{ }^{\circ} \mathrm{C}, 350$ bar)

Figure 10. Breaking time evolution with temperature and pressure (a), particle diameter (b) and volumetric flow (c). 


\section{Chapter 1}

Table 7. Breaking times ( $t_{c 1}$ and $\left.t_{c 2}\right)$ adjustment.

\begin{tabular}{|c|c|c|c|}
\hline \multicolumn{4}{|c|}{$\mathrm{t}_{\mathrm{c} 2}(\min )$} \\
\hline \multirow{2}{*}{$\mathrm{P}$ (bar) } & \multicolumn{3}{|c|}{$\mathrm{T}\left({ }^{\circ} \mathrm{C}\right)$} \\
\hline & 50 & 60 & 70 \\
\hline 300 & 89 & 97 & 105 \\
\hline 250 & 166 & 180 & 220 \\
\hline 350 & 60 & 62 & 63 \\
\hline $\mathrm{R}^{2}$ & 0.93 & 0.95 & 0.93 \\
\hline \multicolumn{2}{|c|}{$\mathrm{t}_{\mathrm{c} 2}(\min )$} & \multicolumn{2}{|c|}{$\mathrm{t}_{\mathrm{c} 2}(\min )$} \\
\hline $\mathrm{dp}(\mu \mathrm{m})$ & \multicolumn{3}{|c|}{$\mathrm{Q}(\mathrm{mL} / \mathrm{min})$} \\
\hline 450 & 62 & 1.00 & 140 \\
\hline 890 & 130 & 2.00 & 62 \\
\hline 1180 & 150 & 3.00 & 40 \\
\hline $\mathrm{R}^{2}$ & 0.995 & $\mathrm{R}^{2}$ & 0.97 \\
\hline \multicolumn{4}{|c|}{$\mathrm{t}_{\mathrm{c} 1}(\min )$} \\
\hline \multicolumn{4}{|l|}{$\mathrm{P}(\mathrm{bar})$} \\
\hline 300 & 30 & & \\
\hline 250 & 36 & & \\
\hline
\end{tabular}

\subsection{Simulation of the internal behaviour}

Once the optimization has been finished, a simulation with the calculated parameters can be done. In Figure 11-b the simulation of the solid behaviour inside the column is shown. It can be checked that the calculated result agrees with the expected evolution. So, a decreasing concentration profile for each time is obtained up to reach a minimum at 90 min, when internal diffusion controls. In the same way, the liquid profile inside the column was also simulated (Figure 11-b). Obtaining, again, a decreasing concentration with time (due to solid exhaustion) up to another minimum at $90 \mathrm{~min}$. These simulations would be useful to understand how the extraction process is and to estimate would the composition of the solid at any time and any point, which would be one of the main variables to decide to stop the process. 


\section{Chapter 1}

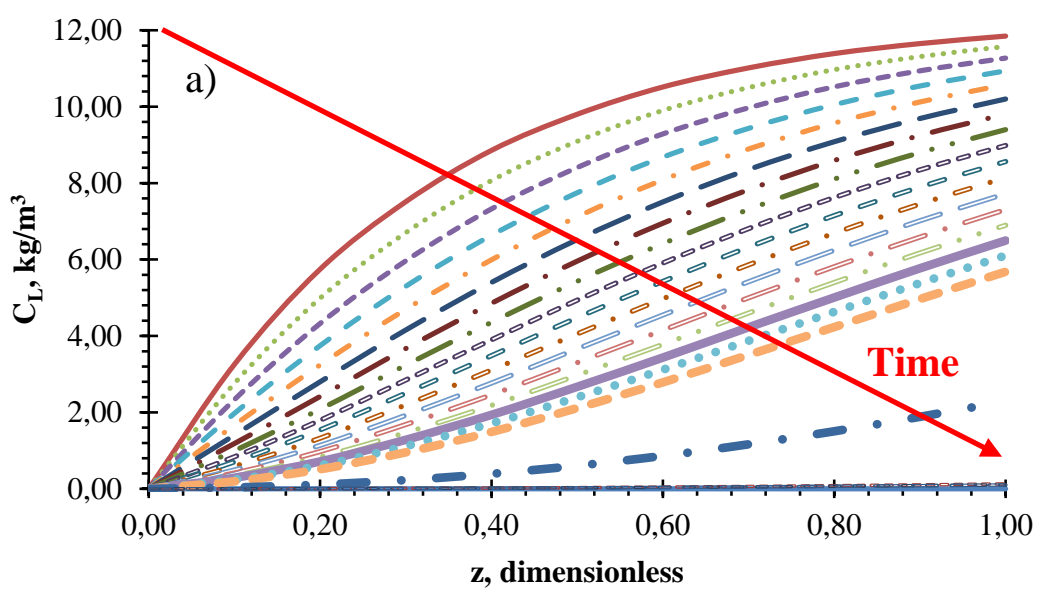

$$
\begin{aligned}
& \longrightarrow \quad 0 \quad 5 \quad \cdots \cdots \cdot 10 \quad---.15---20 \quad-25 \\
& --30-.35-\cdots 400000045 \text { ○ }-50 \text { - }-55
\end{aligned}
$$

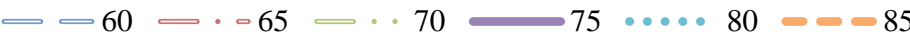

$$
\begin{aligned}
& \text { - } 90 \text {-00000095 - - - } 150---210
\end{aligned}
$$

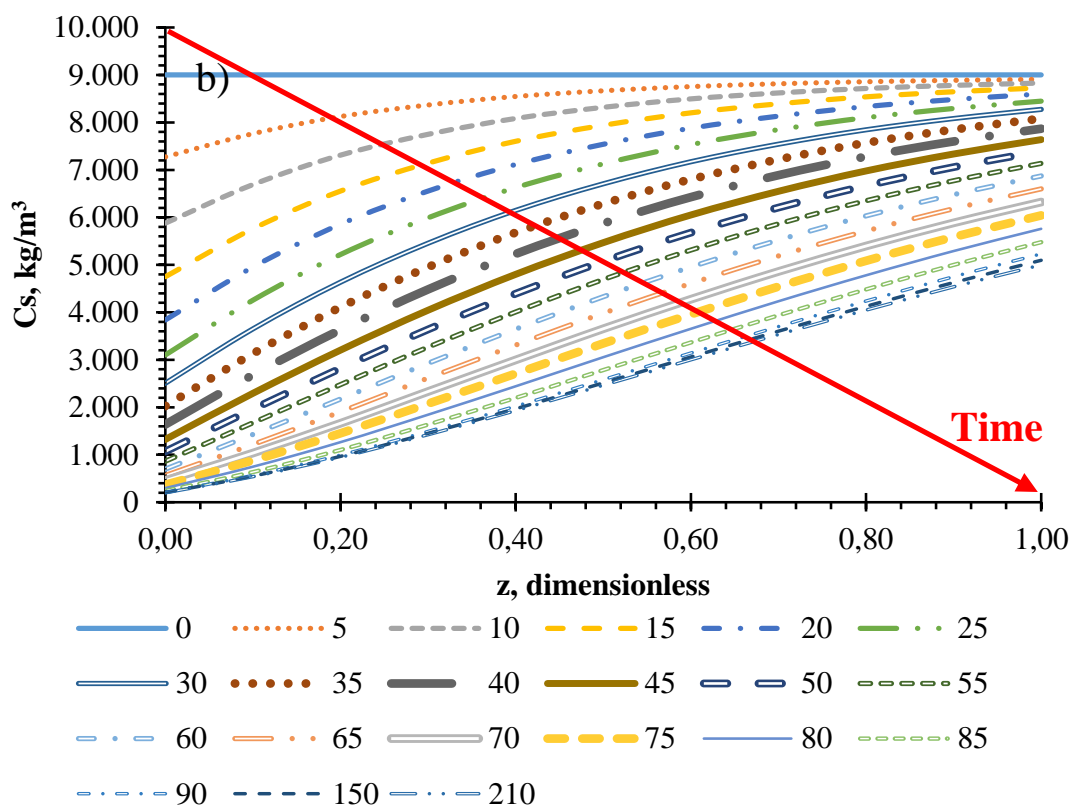

Figure 11. Internal behaviour of the liquid (a) and solid (b) simulation in experiment 1. 


\section{Excel interface considerations}

As it was remarked in section 1, an easy-understudying Excel interface has been developed to adjust the experimental data of a SFE process. This interface also simulates the behaviour inside the column in both phases (SCF and solid), allowing to the user to analyse the effect of the operational variables. This program (with a detailed manual) is free-available at http://hpp.uva.es/software/. In addition, it was concluded in section 4 that this program can be used to fit the SFE of caffeine and oil. However, it could be used with any other solid or solvent since it was based on a general model. This last statement would be true if the bed porosity can be assumed as a constant and the equilibrium follows a Henry's relation. Moreover, if the porosity is assumed to be constant, the model could be just used for processes where the affected substances did not have a structural role.

\section{Conclusions}

In this work the modelling for SFE processes has been assessed, developing a free available Excel interface. The model was successfully validated with two different samples, sesame seeds and coffee beans (average deviations of $7.41 \%$ and $10.35 \%$, respectively). Moreover, the model could reproduce the effect of temperature, pressure, particle diameter and flow in all the cases and the physical sense of the fitted parameters was checked. Finally, the model was also able to simulate the behavior of the SCF and the solid inside the column, which constitutes a useful tool for understanding or teaching the process and taking operational decisions.

\section{Nomenclature}

Acronyms

A.A.D.: Average Absolute Deviation.

SCF: supercritical fluid.

SFE: supercritical fluid extraction.

$\mathrm{ScCO}_{2}$ : supercritical $\mathrm{CO}_{2}$.

BSG : brewer's spent grain.

Subindex and superindex

Y-EXP: experimental extraction yield. 


\section{Chapter 1}

Y-SIM: simulated extraction yield.

Greek letters and symbols

$\mathcal{E}$ : porosity of the bed, dimensionless.

$\mathrm{C}_{\mathrm{S}}$ : concentration of the compound in the solid phase, $\mathrm{kg} / \mathrm{m}^{3}$.

$\mathrm{k}_{\mathrm{SCF}} \cdot a_{S C F}$ : external mass transfer coefficient multiplied by the specific exchange area, $\min ^{-1}$.

$\mathrm{k}_{\mathrm{S}} \cdot a_{S}$ : internal mass transfer coefficient multiplied by the specific exchange area, $\min ^{-1}$.

$K \cdot a_{S}$ : global mass transfer coefficient multiplied by the specific exchange area, $\min ^{-1}$.

$\mathrm{C}_{\mathrm{SCF}}^{*}$ : equilibrium concentration in the $\mathrm{SCF}, \mathrm{kg} / \mathrm{m}^{3}$.

$\mathrm{C}_{\mathrm{SCF}}$ : concentration of the in the $\mathrm{SCF}, \mathrm{kg} / \mathrm{m}^{3}$.

$\mathrm{H}$ : equilibrium constant between the solid and the SCF, dimensionless.

F: correction factor for stage B, dimensionless.

$\mathrm{u}$ : SCF velocity in the column, $\mathrm{m} / \mathrm{min}$.

L: length of the column, m.

Z: coordinate along the length of the reactor, dimensionless.

t: operating time, min.

$\mathrm{t}_{\mathrm{c}_{1}} \& t_{c_{2}}:$ breaking times, min.

$\mathrm{x}_{\mathrm{i}_{\text {EXP }}}$ : experimental value of the fitted variable in the experiment " $\mathrm{i}$ ".

$\mathrm{X}_{\mathrm{iSIM}}$ : simulated value of the fitted variable in the experiment " $\mathrm{i}$ "..

$\mathrm{n}$ : total number of experiments, dimensionless.

T: operating temperature, ${ }^{\circ} \mathrm{C}$.

$\mathrm{P}$ : operating pressure, bar.

Q: volumetric flow, $\mathrm{mL} / \mathrm{min}$.

$\mathrm{d}_{\mathrm{P}}:$ particle diameter, $\mu \mathrm{m}$. 


\section{Acknowledgements}

The authors acknowledge the Spanish Economy and Competitiveness Ministry, Project Reference: ENE2012-33613 for funding. Álvaro Cabeza would like to thank to the Spanish Ministry of Education Culture and Sports, training program of university professors (reference FPU2013/01516) for the research training contract.

\section{References}

de Melo, M.M.R., Silvestre, A.J.D., Silva, C.M. 2014. Supercritical fluid extraction of vegetable matrices: Applications, trends and future perspectives of a convincing green technology. The Journal of Supercritical Fluids, 92, 115-176.

Dobbs, J.M., Wong, J.M., Johnston, K.P. 1986. Nonpolar co-solvents for solubility enhancement in supercritical fluid carbon dioxide. Journal of Chemical \& Engineering Data, 31(3), 303-308.

Döker, O., Salgin, U., Yildiz, N., Aydoğmuş, M., Çalimli, A. 2010. Extraction of sesame seed oil using supercritical $\mathrm{CO} 2$ and mathematical modeling. Journal of Food Engineering, 97(3), 360-366.

Henley, E.J., Seader, J.D. 1981. Equilibrium-Stage Separation Operations in Chemical Engineering. John Wiley \& Sons, Inc.

Honarvar, B., Sajadian, S.A., Khorram, M., Samimi, A. 2013. Mathematical modeling of supercritical fluid extraction of oil from canola and sesame seeds. Brazilian Journal of Chemical Engineering, 30, 159-166.

Kritzer, P., Boukis, N., Dinjus, E. 1999. Factors controlling corrosion in high-temperature aqueous solutions: a contribution to the dissociation and solubility data influencing corrosion processes. The Journal of Supercritical Fluids, 15(3), 205227.

Lack, E., Seidlitz, H. 1993. Commercial scale decaffeination of coffee and tea using supercritical CO2. in: Extraction of Natural Products Using Near-Critical Solvents, (Eds.) M.B. King, T.R. Bott, Springer Netherlands, pp. 101-139.

Manivannan, G., Sawan, S.P. 1998. 1 - The Supercritical State. in: Supercritical Fluid Cleaning, (Ed.) J.M.P. Sawan, William Andrew Publishing. Westwood, NJ, pp. $1-21$.

Nahar, L., Sarker, S. 2012. Supercritical Fluid Extraction in Natural Products Analyses. in: Natural Products Isolation, (Eds.) S.D. Sarker, L. Nahar, Vol. 864, Humana Press, pp. 43-74. 
Nerome, H., Ito, M., Machmudah, S., Wahyudiono, Kanda, H., Goto, M. Extraction of phytochemicals from saffron by supercritical carbon dioxide with water and methanol as entrainer. The Journal of Supercritical Fluids.

Peker, H., Srinivasan, M. P., Smith, J. M. and McCoy, B. J. 1992. Caffeine extraction rates from coffee beans with supercritical carbon dioxide. AIChE J, 38, 761-770.

Press, W., Teukolsky, S., Vetterling, W., Flannery, B. 2007. Numerical recipes 3rd edition: The art of scientific computing.

Rai, A., Mohanty, B., Bhargava, R. 2016. Supercritical extraction of sunflower oil: A central composite design for extraction variables. Food Chemistry, 192, 647-659.

Sovová, H. 1994. Rate of the vegetable oil extraction with supercritical CO2-I. Modelling of extraction curves. Chemical Engineering Science, 49(3), 409-414.

Spinelli, S., Conte, A., Lecce, L., Padalino, L., Del Nobile, M.A. 2016. Supercritical carbon dioxide extraction of brewer's spent grain. The Journal of Supercritical Fluids, 107, 69-74.

\section{List of Tables and Figures}

Table 1. Studied experiments and their operational conditions.

Table 2. A.A.D. of the adjustments.

Table 3. Fitted sesame oil equilibrium constant.

Table 4. Fitted caffeine equilibrium constant.

Table 5. Fitted sesame oil external and internal mass transfer coefficients, including the correction factor $(\mathrm{F})$ for stage $\mathrm{B}$.

Table 6. Fitted global mass transfer coefficient for caffeine.

Table 7. Breaking times ( $t_{c 1}$ and $\left.t_{c 2}\right)$ adjustment.

Figure 1. Process flow diagram of a typical SFE process with $\mathrm{CO}_{2}$. T-01: gas bottle, $\mathrm{H}-$ 01: heat exchanger, P-01: pump, E-01: extraction column, V-01: expansion valve and T02: expansion vessel.

Figure 2. Mass transfer steps during an extraction (a) and their effect in the extraction curve (b). 1: solubilisation, 2: internal diffusion of the extracted compound and 3: external mass transfer of the extracted compound. A: extraction controlled by the external 
transport, B: extraction controlled by both: external transport and internal diffusion and $\mathrm{C}$ : extraction controlled by internal diffusion.

Figure 3. Dielectric properties changes in water with temperature at $24 \mathrm{MPa}$ (Kritzer et al., 1999).

Figure 4. Effect of the operating temperature and pressure in a SCF extraction. (a) Effect of the operating pressure in the oil extraction from sesame seeds at $50{ }^{\circ} \mathrm{C}, 2 \mathrm{~mL} / \mathrm{min}$ and $450 \mu \mathrm{m}$. (b) Effect of the operating pressure in the caffeine extraction from coffee beans at $50{ }^{\circ} \mathrm{C}$ and $1.51 \mathrm{~mL} / \mathrm{min}$. (c) Effect of the operating temperature in the oil extraction from sesame seeds at $250 \mathrm{bar}, 2 \mathrm{~mL} / \mathrm{min}$ and $450 \mu \mathrm{m}$. (d) Effect of the operating temperature in the caffeine extraction from coffee beans at $138 \mathrm{bar}$ and $1.51 \mathrm{~mL} / \mathrm{min}$. YSIM: simulated extraction yield ( $\left.\mathrm{g}_{\text {extracted }} / \mathrm{g}_{\text {sample }}\right)$. Y-EXP: experimental extraction yield $\left(\mathrm{g}_{\text {extracted }} / \mathrm{g}_{\text {sample }}\right)$.

Figure 5: Particle diameter and volumetric flow effects. (a) Role of the volumetric flow in the oil extraction from sesame seeds at $50{ }^{\circ} \mathrm{C}, 350$ bar and $450 \mu \mathrm{m}$. (b) Role of the volumetric flow in the oil caffeine from coffee beans at $50{ }^{\circ} \mathrm{C}$ and 138 bar. (c) Role of the particle diameter in the oil extraction from sesame seeds at $50{ }^{\circ} \mathrm{C}, 350 \mathrm{bar}$ and $2 \mathrm{~mL} / \mathrm{min}$. Y-SIM: simulated extraction yield ( $\left.g_{\text {extracted }} / \mathrm{g}_{\text {sample }}\right)$. Y-EXP: experimental extraction yield ( $\left.\mathrm{g}_{\text {extracted }} / \mathrm{g}_{\text {sample }}\right)$.

Figure 6. Sesame oil equilibrium constant evolution with temperature and pressure (a) and changes in $\mathrm{ScCO}_{2}$ with temperature and pressure.

Figure 7. Caffeine equilibrium constant evolution with temperature (a) and pressure (c) and changes in $\mathrm{ScCO}_{2}$ density with temperature (b) and pressure (d).

Figure 8. Sesame oil external mass transfer dependency with flow (a) and particle diameter (b) and internal mass transfer evolution with particle diameter (c).

Figure 9. Caffeine global mass transfer coefficient dependency with flow.

Figure 10. Breaking time evolution with temperature and pressure (a), particle diameter (b) and volumetric flow (c).

Figure 11. Internal behaviour of the liquid (a) and solid (b) simulation in experiment 1. 


\section{Chapter 1}


Chapter 2

CHAPTER 2 



\title{
Autocatalytic kinetic model for thermogravimetric analysis and composition estimation of biomass and polymeric fractions
}

\author{
A. Cabeza, F. Sobrón, F.M. Yedro, and J. García-Serna*
}

High Pressure Processes Group, Department of Chemical Engineering and Environmental Tech., University of Valladolid, 47011 Valladolid, Spain

*Corresponding author: Tel.: +34 983184934

E-mail: jgserna@iq.uva.es (J. García-Serna)

\section{DOI: $\underline{\text { https://doi.org/10.1016/j.fuel.2015.01.048 }}$}

\begin{abstract}
A comprehensive kinetic model of slow pyrolysis of biomass during a Thermogravimetric analysis (TGA) has been developed, including the simulation of variable heating rates, composition estimation and structural analysis of biomass. Biomass was assumed as a matrix of three solid global components (hemicellulose, cellulose and lignin) in which water and oil can be also present.

Kinetics were based on an auto-catalytic model because it can simulate the degradation in cellulosic materials, as the cleavage of the biopolymers produce oligomers that accelerate the further depolymerisation. The reaction pathway followed the Waterloo's mechanism, which stablishes that all solid compounds decompose into volatiles and charcoal. This mechanism was completed by the vaporization of water and oil, and assuming that the formed charcoal can break into volatiles by a slow reaction. The set was solved by the $8^{\text {th }}$ Runge-Kutta's method and validated by the Simplex Nelder-Mead and Broyden-Fletcher-Goldfarb-Shanno's methods. The development of this model has a high interest because it can help to understand how the conversion from biomass to biochemicals takes place.

To assess what parameters can affect the thermal degradation of biomass pure polymeric samples of hemicellulose, cellulose and lignin and complex samples (seeds and woody biomass) were studied and fitted. Two types of operations were considered too. An isothermal degradation from $150^{\circ} \mathrm{C}$ up to $350^{\circ} \mathrm{C}$ with increments of $50{ }^{\circ} \mathrm{C}$, and a nonisothermal decomposition with heating rate of $5{ }^{\circ} \mathrm{C} / \mathrm{min}, 10^{\circ} \mathrm{C} / \mathrm{min}$ and $20^{\circ} \mathrm{C} / \mathrm{min}$ up to
\end{abstract}




\section{Chapter 2}

temperatures around $800{ }^{\circ} \mathrm{C}$, depending on the studied sample. Average absolute deviations lower than $7 \%$ were obtained. It was deduced that there are some interactions between the three main biomass compounds. These interactions were observed by the variations in the kinetic parameters between complex and pure samples, also they were perceived between the isothermal and no-isothermal way. On the other hand, an effect of the biomass structure has been reported by the differences between the kinetics of the seeds and of the woody samples. It is remarkable that the developed model could reproduce the cellulose decomposition with a variable heating rate using a unique set of kinetic parameters. This was possible by a no-Arrhenius' dependence with temperature. In the same way, it was used to predict the initial composition of the studied biomass with deviations lower than $7 \%$ for lignin and cellulose.

Keywords: Autocatalytic kinetic, composition estimation, TGA, cellulose, hemicellulose, lignin.

\section{Introduction}

The use of fossil fuels as the main raw material for industry is not sustainable, and certainly it will not be the forever-solution. So a new source of basic compounds (i.e. carbon, hydrogen and oxygen) and energy should be considered. This new source could be biomass (Clark et al., 2006), which can be transformed into bioenergy, biochemical and biofuels in biorefineries (Bozell, 2008; Cheng \& Zhu, 2009). However, the design of these biorefineries requires knowledge about the conversion from raw material to fuels and fast, cheap and accurate biomass-analysing methods. For the latter, several wet methods of chemical analysis have been used (Carrier et al., 2011). These methods are based on the fractionation of biomass samples and a later isolation of purified fractions, which could be quantified using conventional analytical instruments. Although these techniques have high accuracy and robustness, they are not suitable for an industrial scale because they are expensive and require a lot of time. Another option would be spectroscopic analysis, such as, the Near Infrared Reflectance (NIR) spectroscopy, which reduces time requirements and cost and it is a method with a high reproducibility. Nevertheless, these analyses need data with a very high quality and an initial blank spectrum, which is an important limitation. So, the measurement of the initial biomass composition is an issue that have not an optimal solution yet. Thermogravimetric analysis 
(TGA) of biomass could be the answer for this problem under certain conditions. In addition, it can provide information about how the thermal decomposition takes place. Thermogravimetric analysis is a slow pyrolysis process which consist of recording the mass variation of a sample which is treated with a temperature profile. This profile is provided by a gas phase which can be an inert or an oxidant compound (Williams \& Besler, 1996). This type of analysis have been studied thoroughly (Chen et al., 2011; Lv et al., 2010; Williams \& Besler, 1996) and there are a lot of works about their modelling in the literature. The most extended model considers a first order kinetic for each compound present in biomass assuming that biomass is formed by three main compounds (cellulose, hemicellulose and lignin). These components decompose to charcoal and volatiles by independent reactions. S. Völker (S. Völker, 2002) used a first order kinetic to adjust the decomposition of pure cellulose and the deviation between the experimental data and the simulation was relatively high. In contrast, Capart et al. (Capart et al., 2004) studied the pure cellulose thermal breaking but considering an autocatalytic model which supposed a good fitting with an overall deviation around $1 \%$. On the other hand, V. Mangut et al. (Mangut et al., 2006) proposed a kinetic model of $\mathrm{n}^{\text {th }}$-order for the degradation of residues from tomato processing industry which could reproduce the biomass behaviour. But A. Zabaniotoua et al. (Zabaniotou et al., 2008), K. Slopiecka et al. (Slopiecka et al., 2012) and E. Kastanaki et al. (Kastanaki et al., 2002) studied the TGA kinetics of several lignocellulosic biomass samples, poplar wood and lignitebiomass blends respectively with a first order model and they obtained good fits too. $K$. Slopiecka et al. and A. Zabaniotoua et al. fitted their TGA as a single compound, which is useful to reproduce the decomposition. However, it is not capable of reproducing the individual behaviour of the biomass components and ensuring that the obtained parameters have physical meaning. On the other hand, E. Kastanaki et al. and V. Mangut et al. adjusted their TGA with individual kinetics for each biomass compound. Therefore, the behaviour of each of them could be simulated and the physical sense of the parameters checked. Nevertheless, they did not study the causes of the variations in the kinetics of the biomass components assuming that there are no interactions between them. Taking into account this big range of possible models it is difficult to select one because any of them could be a good way to simulate the thermal degradation of biomass. Finally, the autocatalytic model is the option selected in this work due to the fact that it can reproduce the steep changes in cellulosic material better than a first or $\mathrm{n}^{\text {th }}$-order model. 


\section{Chapter 2}

The aim of this paper is to study the main parameters that affect to the thermal decomposition of lignocellulosic biomass in a thermogravimetric analysis developing a model which could reproduce the decomposition of any sample of biomass and its components in an isothermal or non-isothermal process and at any heating rate. The last one is important because a discrepancy in the amount of formed charcoal has been reported by other authors (Capart et al., 2004; Elyounssi et al., 2012; S. Völker, 2002; Slopiecka et al., 2012; Van de Velden, 2010) when different heating rates are used. Furthermore, the causes of the changes in the kinetics of the individual biomass components with the type of samples or process was assessed by the comparison of the kinetics parameters, which is not generally done in previous studies. In addition, this model should be able to estimate the initial composition of the degraded sample from the thermogravimetric analysis and from the kinetic parameters fitted previously. This capacity is important because it is a new use for the TGA modelling and, if it is developed correctly, it would become an economic option to obtaining the initial composition of the biomass.

\section{Materials and methods}

\subsection{Materials}

Grape seeds from Vitis vinifera $L$ (Tempranillo) from Matarromera S.A. winery (Valbuena de Duero, Spain) campaign 2011 and several woody wastes were used as raw material. Material for this study was ground to a particle size of $0.5-1.0 \mathrm{~mm}$.

The reagents used for HPLC analysis were: cellobiose (+98 \%), glucose (+99\%), fructose (+99\%), glyceraldehyde (95\%), pyruvaldehyde (40\%), arabinose (+99\%), 5hydroxymethylfurfural (99\%), lactic acid (85\%), formic acid (98\%), acrylic acid (99\%), mannose (+99\%), xylose (+99\%) and galactose (+99\%) purchased from Sigma and used without further modification. For the structural carbohydrates and lignin determination sulfuric acid (98\%) and calcium carbonate ( $\geq 99.0 \%$ ) were used as reagents supplied by Sigma too. 


\section{Chapter 2}

\subsection{Biomass characterization}

\subsubsection{Sugar content}

The sugar content measurement of a biomass sample requires its hydrothermal fractionation followed by a hydrolysis of the product which will be fed to a HPLC later. The hydrolysis is needed because the fractionation generates a range of polymeric fractions and compounds which could not be directly identified in a HPLC. So, they have to be cleaved by a further hydrolysis into their basic units or monomers, e.g. glucose, fructose, xylose and arabinose.

The samples were hydrolysed adding $3.00 \pm 0.01 \mathrm{ml}$ of sulphuric acid (72\%) to $15 \mathrm{ml}$ of each aliquot. Each sample was incubated in a forced convection oven for $30 \pm 5 \mathrm{~min}$ at $30 \pm 3{ }^{\circ} \mathrm{C}$. After this time, the samples were taken out from the oven, they were diluted by $84.00 \pm 0.04 \mathrm{~mL}$ of deionized water and finally they were placed in the oven for 1 hour at $121^{\circ} \mathrm{C}$. Afterwards, the solution was cooled down to room temperature and it was filtered under vacuum. Before injecting in the HPLC the samples were neutralized to $\mathrm{pH}=6-7$ using calcium carbonate.

The HPLC column used for the separation of the compounds was a SUGAR SH-1011 Shodex at $50{ }^{\circ} \mathrm{C}$ at a flow of $0.8 \mathrm{~mL} / \mathrm{min}$ using a solution of $0.01 \mathrm{~N}$ of sulphuric acid and Milli-Q water as mobile phase. A Waters IR detector 2,414 and Waters dual $\lambda$ absorbance detector 2487 ( $210 \mathrm{~nm}$ and $254 \mathrm{~nm}$ ) were used to identify the sugars and their derivatives.

\subsubsection{Solid analysis. Klason lignin determination and sugars attached to the solid}

The raw material and the solid residue generated by the hydrolysis were analysed for lignin content using the Klason assay according to the TAPPI standard method T-222 om98 (Meng et al., 2012). To do so, $300 \mathrm{mg}$ of sample was put into laboratory glass bottles, $3 \mathrm{~mL}$ of sulfuric acid $(72 \%)$ was added and it was incubated during $30 \mathrm{~min}$ at $30^{\circ} \mathrm{C}$ and it was shaken vigorously every 5-10 $\mathrm{min}$. Then, the mixture was diluted with $84 \mathrm{~mL}$ of deionized water and it was placed in an oven for $1 \mathrm{~h}$ at $121^{\circ} \mathrm{C}$. At that moment, the sample was taken out from the oven, cooled down to room temperature and the mixture was filtered under vacuum. The obtained solid after filtration was dried at $105^{\circ} \mathrm{C}$ for $24 \mathrm{~h}$, it was cooled down in a desiccator and then it was weighted. This solid was introduced in the calcination oven at $550{ }^{\circ} \mathrm{C}$ for $24 \mathrm{~h}$ to determine the ash content. Considering the weight differences, the Klason lignin content was calculated. The hydrolysis liquid was 
neutralized with calcium carbonate to $\mathrm{pH}=6-7$, then it was filtered and analysed by HPLC as explained in section 2.2.1.

The initial composition calculated by the methods described in 2.2.1 and 2.2.2 is collected in Table 1.

\subsection{Experimental set-up and procedure}

TGA were carried out in a TGA/SDTA RSI analyser of Mettler Toledo. Samples of approximately $10 \mathrm{mg}$ were heated from $50^{\circ} \mathrm{C}$ to the required temperature at a rate of 20 ${ }^{\circ} \mathrm{C} /$ min under $\mathrm{N}_{2}$ atmosphere $(60 \mathrm{NmL} / \mathrm{min}$ flow) to determine the carbonization. The final temperature changed with the type of analysis. If the study was at isothermal conditions it had a value between $150{ }^{\circ} \mathrm{C}$ and $350^{\circ} \mathrm{C}$. However, when it was no isothermal the biomass was heated up to temperatures around $800{ }^{\circ} \mathrm{C}$.

\subsubsection{Procedure for the analysis of the effect of the composition}

Thermogravimetric analysis at variable temperature with a heating rate of $20{ }^{\circ} \mathrm{C} / \mathrm{min}$ of woody samples with different lignin content were fitted. So, the difference between the kinetics parameters were used to discover how the composition affects to the thermal degradation. TGA of hemicellulose, cellulose and grape skins, which does not have lignin, at the same heating rate were performed to study this factor too.

\subsubsection{Procedure for the analysis of the effect of the structure}

The effect of the biomass structure was studied comparing the adjusted kinetic parameters obtained from the TGA (with a heating rate of $20^{\circ} \mathrm{C} / \mathrm{min}$ ) of two types of pure lignin: an alkaline lignin and a sample from Turku, Finland. The last one was extracted using a hydrotropic substance, the p-toluene sulfonate. In addition, the deviation of the kinetics parameters between the TGA (heating rate of $20^{\circ} \mathrm{C} / \mathrm{min}$ ) of a sample of grape seeds and grape seeds extracted with a mixture of ethanol/water (70/30) for 1 hour was considered. The kinetics variation between these grape seeds and hydrolysed grape seeds for 1 hour at three different temperatures $\left(250{ }^{\circ} \mathrm{C}, 300{ }^{\circ} \mathrm{C}\right.$ and $\left.340{ }^{\circ} \mathrm{C}\right)$ and at a heating rate of 20 ${ }^{\circ} \mathrm{C} / \mathrm{min}$ were analysed too. 


\subsubsection{Procedure for the analysis of the effect of the heating rate.}

The role of the heating rate was considered by fitting TGA of pure cellulose at three different heating rates: $5{ }^{\circ} \mathrm{C}, 10{ }^{\circ} \mathrm{C}, 20{ }^{\circ} \mathrm{C}$ and comparing the values of their kinetics parameters.

\subsubsection{Procedure for the analysis of the effect of the isothermal conditions}

This factor was studied by the adjustment of the TGA of Acer Saccharum, a type of maple, at 5 temperatures $\left(150^{\circ} \mathrm{C}, 200^{\circ} \mathrm{C}, 250^{\circ} \mathrm{C}, 300^{\circ} \mathrm{C}\right.$ and $\left.350{ }^{\circ} \mathrm{C}\right)$ with a heating rate of 20 ${ }^{\circ} \mathrm{C} / \mathrm{min}$ and considering the modifications in the kinetics.

\section{Mathematical model}

\subsection{Biomass composition}

The solid organic compounds present in biomass are divided in three main biopolymer fractions: hemicellulose, cellulose and lignin. Hemicellulose and cellulose are constituted by monomeric sugars. The difference between them is that cellulose is a linear polymer of anhydroglucopyranose (hexose) units linked by ether bonds, while hemicellulose is a branched and amorphous polymer formed by both pentoses and hexoses. In contrast, lignin is a complex, cross-linked, three-dimensional aromatic polymer formed with phenylpropane units (Bobleter, 1994). The lower the amount of lignin the more flexible is the biomass (e.g. herbs). In addition, some inerts (inorganic mineral compounds) and two liquid phases can be present inside the biomass: water and an organic phase which is identified in this work as oil.

Simplifying the raw biomass structure, we can consider that the cellulose microfibers are connected by hemicellulose in 3D structure of lignin that encloses and protects them (Figure 1). The structure of the biopolymer fractions and other kinds of biomass ligninlean can be a bit different. 


\section{Chapter 2}

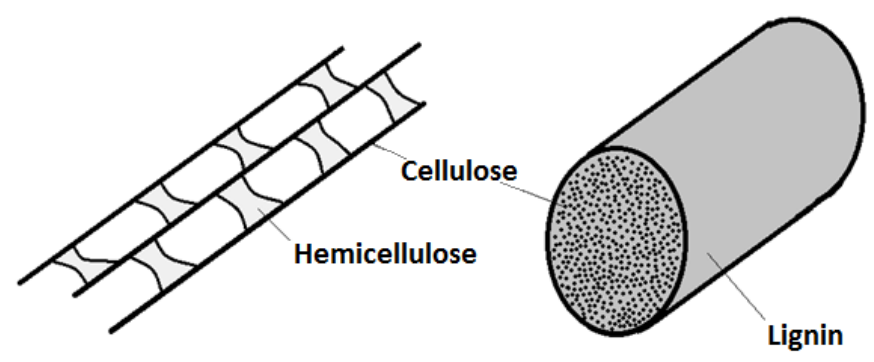

Figure 1. Schema of the biomass structure.

Table 1. Initial composition of the samples.

\begin{tabular}{|c|c|c|c|c|c|c|c|c|c|}
\hline & $\begin{array}{l}\text { Water } \\
(\mathrm{g} / \mathrm{g})\end{array}$ & $\begin{array}{l}\text { Oil } \\
(\mathrm{g} / \mathrm{g})\end{array}$ & $\begin{array}{l}\text { Hemicellulose } \\
(\mathrm{g} / \mathrm{g})\end{array}$ & $\begin{array}{l}\text { Cellulose } \\
(\mathrm{g} / \mathrm{g})\end{array}$ & $\begin{array}{l}\text { Lignin } \\
(\mathrm{g} / \mathrm{g})\end{array}$ & $\begin{array}{c}\text { CharHemicellulose } \\
(\mathrm{g} / \mathrm{g})\end{array}$ & $\begin{array}{l}\text { CharCellulose } \\
\text { (g/g) }\end{array}$ & $\begin{array}{l}\text { CharLignin } \\
(\mathrm{g} / \mathrm{g})\end{array}$ & $\begin{array}{l}\text { Inert } \\
(\mathrm{g} / \mathrm{g})\end{array}$ \\
\hline Hemicellulose & 0.030 & 0.000 & 0.970 & 0.000 & 0.000 & 0.000 & 0.000 & 0.000 & 0.000 \\
\hline Cellulose & 0.009 & 0.000 & 0.000 & 0.991 & 0.000 & 0.000 & 0.000 & 0.000 & 0.000 \\
\hline Lignin (Turku) & 0.011 & 0.000 & 0.000 & 0.000 & 0.989 & 0.000 & 0.000 & 0.000 & 0.000 \\
\hline Lignin (Alkaline) & 0.038 & 0.000 & 0.000 & 0.000 & 0.962 & 0.000 & 0.000 & 0.000 & 0.000 \\
\hline $\begin{array}{c}\text { No extracted } \\
\text { seeds }\end{array}$ & 0.029 & 0.166 & 0.146 & 0.214 & 0.419 & 0.000 & 0.000 & 0.000 & 0.026 \\
\hline Extracted Seeds & 0.015 & 0.000 & 0.180 & 0.264 & 0.515 & 0.000 & 0.000 & 0.000 & 0.027 \\
\hline \multicolumn{10}{|l|}{ Hydrolysed Seeds } \\
\hline $250^{\circ} \mathrm{C}$ & 0.019 & 0.000 & 0.054 & 0.239 & 0.463 & 0.104 & 0.030 & 0.050 & 0.041 \\
\hline $300^{\circ} \mathrm{C}$ & 0.019 & 0.000 & 0.000 & 0.259 & 0.463 & 0.110 & 0.040 & 0.069 & 0.041 \\
\hline $340^{\circ} \mathrm{C}$ & 0.019 & 0.000 & 0.000 & 0.029 & 0.416 & 0.110 & 0.248 & 0.090 & 0.088 \\
\hline Seed skin & 0.014 & 0.100 & 0.360 & 0.439 & 0.000 & 0.000 & 0.000 & 0.000 & 0.087 \\
\hline Lime & 0.014 & 0.049 & 0.215 & 0.494 & 0.209 & 0.000 & 0.000 & 0.000 & 0.019 \\
\hline Plane tree & 0.014 & 0.005 & 0.220 & 0.501 & 0.260 & 0.000 & 0.000 & 0.000 & 0.000 \\
\hline Holm oak & 0.017 & 0.023 & 0.196 & 0.455 & 0.308 & 0.000 & 0.000 & 0.000 & 0.001 \\
\hline Cedar & 0.021 & 0.035 & 0.230 & 0.331 & 0.382 & 0.000 & 0.000 & 0.000 & 0.000 \\
\hline Catalpa & 0.014 & 0.009 & 0.230 & 0.468 & 0.261 & 0.000 & 0.000 & 0.000 & 0.018 \\
\hline Acer Saccharum & 0.015 & 0.015 & 0.213 & 0.426 & 0.329 & 0.000 & 0.000 & 0.000 & 0.000 \\
\hline Almond tree & 0.018 & 0.015 & 0.200 & 0.400 & 0.366 & 0.000 & 0.000 & 0.000 & 0.002 \\
\hline
\end{tabular}




\section{Chapter 2}

\subsection{Reaction pathway}

\subsubsection{Degradation process}

The thermal degradation of biomass in an inert atmosphere (slow pyrolysis conditions) starts with the vaporization of liquid phases. Water evaporates near $100{ }^{\circ} \mathrm{C}$ and oil between $100{ }^{\circ} \mathrm{C}$ and $300{ }^{\circ} \mathrm{C}$. In this research, we intentionally did not dry the biomass until full dryness to mimic as much as possible some kind of humid conditions and therefore the water evaporation.

At $200{ }^{\circ} \mathrm{C}$ lignin begins its decomposition, breaking its weaker parts and enhancing the reaction of hemicellulose and cellulose. Between $250^{\circ} \mathrm{C}$ and $275^{\circ} \mathrm{C}$ hemicellulose reacts and around $300{ }^{\circ} \mathrm{C}$ it disappears completely, which promotes the cellulose breaking. The last one commences its degradation between $300{ }^{\circ} \mathrm{C}$ and $350{ }^{\circ} \mathrm{C}$ and, from this point, only lignin, inert substances and the product from the decomposition (charcoal) remains in the biomass. Lignin depletes at $500{ }^{\circ} \mathrm{C}$ and charcoal continues in the sample with a very low degradation rate. Charcoal only fades completely if the atmosphere is changed to an oxidant compound.

\subsubsection{Reaction mechanism}

The most extended idea in the literature (Capart et al., 2004; Kastanaki et al., 2002; Lv et al., 2010; Mangut et al., 2006; Slopiecka et al., 2012; Williams \& Besler, 1996; Zabaniotou et al., 2008) is a reaction pathway based on the Waterloo-mechanism. This theory establishes that, under slow pyrolysis conditions, biomass decomposes to charcoal and gases via dehydration reactions (Elyounssi et al., 2012; Van de Velden, 2010). Following this theory, it was assumed in this work that any organic solid compound in the biomass could be converted into charcoal and volatiles by independent parallel reactions. Furthermore, an individual charcoal for each solid organic component was used in this paper (Figure 2), with the intention of describing the slow pyrolysis process in detail. This leads to a substantial improvement in the fitting of the experimental data better further prediction. The pathway was completed adding the decomposition of each charcoal to volatiles and with the vaporization of liquid phases if present. 


\section{Chapter 2}

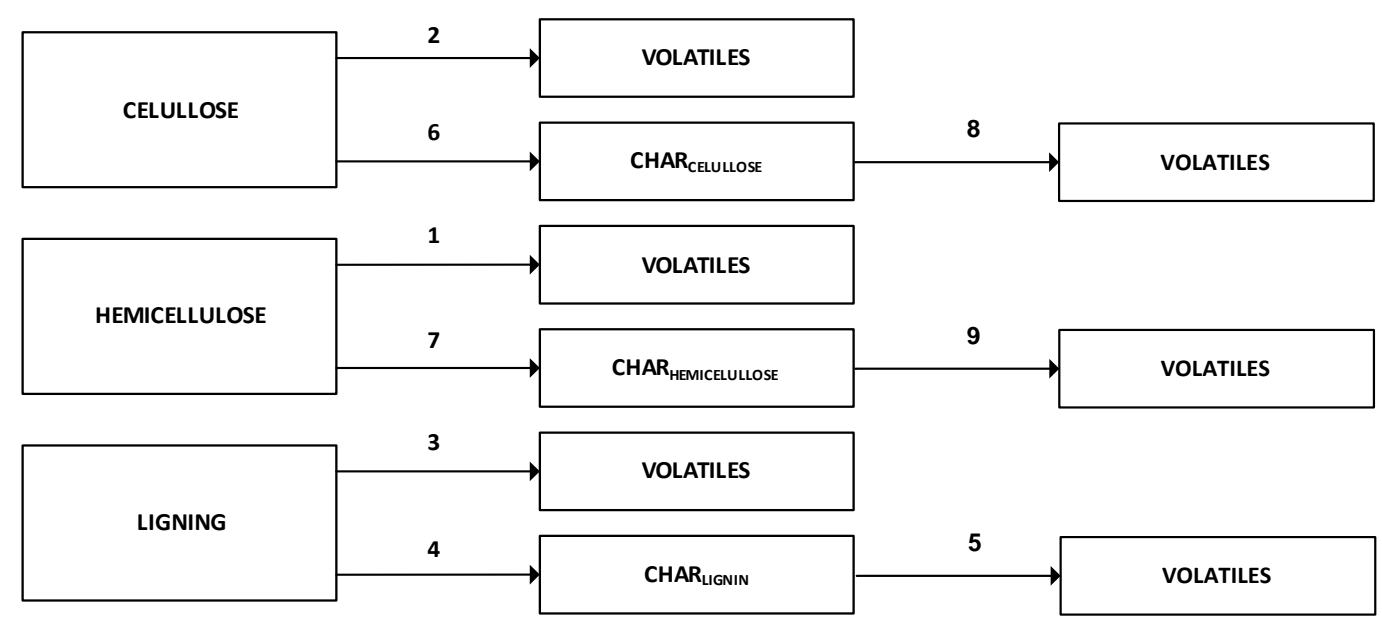

Figure 2. Reaction pathway in a thermal decomposition.

\subsection{The model}

\subsubsection{Assumptions}

Aimed at simplifying the modelling problem, it was assumed that:

a. All the reactions are irreversible and independent. So, the degradation kinetics of each component only depend on their composition and temperature (Kastanaki et al., 2002; Mangut et al., 2006; Slopiecka et al., 2012).

b. There are no energy transport limitations within the biomass particles (as only 10 mg of micronized particles were used for the TGA analysis). Consequently, all the parts of the biomass are at the same temperature.

c. Diffusional mass transport resistances for liquid phases are negligible, as the particles were micronized.

\subsubsection{Mass balances}

The model of the decomposition process considered a non-stationary mass balance for each component in the biomass sample:

$$
\frac{d m_{j}}{d t}=r_{j}=\sum_{i=1}^{N_{r}} g_{i j} \cdot r_{i}
$$

And the total variation of mass was calculated by the addition of all of them:

$$
\frac{d M}{d t}=\sum_{j=1}^{N} \frac{d m_{j}}{d t}
$$




\section{Chapter 2}

\subsubsection{Kinetics}

Mass variation was caused by two different phenomena: reaction kinetics for the solid material and mass transfer of the liquid phases.

- Liquid mass transfer: free oil (or extractable compounds) and free water.

Mass transfer of liquid phases (Eq. ( 3 )) was described by the partial mass transfer coefficient in the gas phase, the mass transfer area and the difference between de equilibrium concentration in the liquid phase and the global concentration in the gas phase (as driving force).

$$
r_{i}=h \cdot S \cdot\left(C_{j}^{*}-C_{j}\right)
$$

As the operating pressure is the atmospheric, the equilibrium concentration (Eq. (4)) was obtained by the ideal gas equation and the vapour pressure calculated by the Antoine equation (Eq. ( 5 )) of each compound. The Antoine's equation coefficients of each liquid phase are compiled in Table 2.

$$
\begin{gathered}
C_{j}^{*}=\frac{P_{j}^{*}}{R \cdot T} \\
\ln \left(P_{j}^{*}\right)=\mathrm{A}_{\mathrm{j}}+\frac{B_{j}}{C_{j}+T}+D_{j} \cdot \ln (T)+E_{j} \cdot T^{F_{j}}
\end{gathered}
$$

Table 2. Antoine's equation coefficients of water (W) and oil (O).

\begin{tabular}{ccc}
\hline & $\mathrm{W}$ & $\mathrm{O}$ \\
\hline $\mathrm{A}_{\mathrm{j}}$ & $6.21 \mathrm{E}+01$ & $1.22 \mathrm{E}+01$ \\
$\mathrm{~B}_{\mathrm{j}}$ & $-7.26 \mathrm{E}+03$ & $5.88 \mathrm{E}+03$ \\
$\mathrm{C}_{\mathrm{j}}$ & $0.00 \mathrm{E}+00$ & $-2.93 \mathrm{E}+02$ \\
$\mathrm{D}_{\mathrm{j}}$ & $7.30 \mathrm{E}+00$ & $0.00 \mathrm{E}+00$ \\
$\mathrm{E}_{j}$ & $4.17 \mathrm{E}-06$ & $0.00 \mathrm{E}+00$ \\
$\mathrm{~F}_{j}$ & $1.00 \mathrm{E}-02$ & $0.00 \mathrm{E}+00$ \\
\hline
\end{tabular}

In addition, the transfer area was considered as a function of the mass in the solid, so the final expression for the mass transfer was: 


$$
r_{i}=h \cdot\left(C_{j}^{*}\right) \cdot m_{j}^{n l_{i}}
$$

- Solid kinetics: for solid organic compounds

As it was mentioned in the introductory section, there are two options for temperature dependent kinetics, i.e. a first order reaction (Eq. ( 7 )) and an autocatalytic reaction (Eq. ( 8 )). The first is the most extended option in the bibliography (Capart et al., 2004; Kastanaki et al., 2002; Mangut et al., 2006; Slopiecka et al., 2012; Zabaniotou et al., 2008) and the second is proposed because its response is very similar to the behaviour of the biomass observed in the literature (Capart et al., 2004) and in previous studies. Both kinetic equations considered an Arrhenius' dependence with temperature.

$$
\begin{gathered}
r_{i}=k_{i} \cdot m_{i}=k_{o_{i}} \cdot e^{-\frac{E a_{i}}{R \cdot T}} \cdot m_{j} \\
r_{i}=k_{o_{i}} \cdot e^{-\frac{E a_{i}}{R \cdot T} \cdot m_{j}^{n_{i}} \cdot\left(1-\alpha_{i} \cdot m_{j}\right)^{\beta_{i}}}
\end{gathered}
$$

The coefficient $\alpha_{i}$ is the initialization factor which indicates the resistance of the biomass against the degradation. It is used to establish the initial value of the reaction velocity. In this work $\alpha_{i}$ was fixed at 0.99 , as it is the most recurrent value in the literature (Capart et al., 2004). The coefficient $\beta_{i}$ is the acceleration factor and represents how fast the degradation is once it has started. The autocatalytic kinetics can predict the dramatic changes in the total mass along with temperature better than a first order kinetics. In view of that, autocatalytic kinetics was the selected option for this work.

In addition, as pure cellulose has been studied at different rates of heating a nonArrhenius' dependence with the temperature was added to Eq. ( 9 ) for this compound. Therefore, the decomposition of cellulose was simulated by equation ( 10 ). This other kind of reaction rate expression was needed because the biomass shows a different behaviour when the heating rate varies along with time (or temperature), as the polymeric structure can both collapse or swell (Capart et al., 2004; Elyounssi et al., 2012; S. Völker, 2002; Van de Velden, 2010). The parameter "c" is a correction factor to the cellulose decomposition when a variable heating rate is used. Nevertheless, we assumed that it could be affected by the biomass structure and heating process too. For this reason, three sets of "c" values are present in Table 7. 


$$
r_{i}=k_{o_{i}} \cdot e^{-\frac{E_{a_{i}}}{R \cdot T}+c \cdot T+\ln (T)} \cdot m_{j}^{n_{i}} \cdot\left(1-\alpha_{i} \cdot m_{j}\right)^{\beta_{i}}
$$

\subsection{Resolution}

The system of 8 ordinary differential equations (ODE) that results from the model was solved by the Runge-Kutta's method with $8^{\text {th }}$ order of convergence (Press et al., 2007). The validation of the model with the experimental data was done applying the Simplex Nelder-Mead method for obtaining an initial estimation of the parameters together with the Broyden-Fletcher-Goldfarb-Shanno's method to improve this initial solution (Press et al., 2007). During the optimization, the optimization range were selected in order to achieve an optimum which would have physical meaning.

The objective function used is the Absolute Average Deviation (AAD) defined as follows:

$$
A A D=\sum_{i=1}^{N} \frac{\left|x_{i_{E X P}}-x_{i_{S I M}}\right|}{x_{i_{E X P}}} \cdot 100
$$

The developed program is available for free in the web page of the research group of high pressure processes of the University of Valladolid (http://hpp.uva.es/software/).

\section{Results and discussion}

\subsection{Pure samples}

This adjustment was done taking into account the theoretical development showed in section 3. The initial composition of each compound is arrayed in Table 1.

\subsubsection{Hemicellulose}

The fitting of pure hemicellulose decomposition (with an average absolute deviation of $2.2 \%$ ) is shown in Figure 3 and the kinetic parameters in Table 7. The mass transfer parameters were averaged for all the samples (complex samples too) and are shown in Table 3. 


\section{Chapter 2}

Table 3. Averaged mass transfer parameters of water $(\mathrm{W})$ and oil $(\mathrm{O})$.

\begin{tabular}{ccc}
\hline & $\mathrm{h}$ & $\mathrm{nli}$ \\
& $\left(\mathrm{kg} \cdot \mathrm{m}^{3} / \mathrm{min} \cdot \mathrm{m}^{2} \cdot \mathrm{kmol}\right)$ & \\
\hline Pure & & \\
$W$ & 1,000 & 2.00 \\
$O$ & - & - \\
Grapes & & \\
$W$ & 1,000 & 2.00 \\
$O$ & 123 & 1.00 \\
Wood & & \\
$W$ & 3,000 & 2.00 \\
$O$ & 123 & 1.00 \\
\hline
\end{tabular}

It can be observed in Figure 3 that there was a first reduction between $50{ }^{\circ} \mathrm{C}$ and $105^{\circ} \mathrm{C}$ which corresponds to water vaporization. There was no decomposition up to $250^{\circ} \mathrm{C}$, when hemicellulose started its degradation. This value agrees with the data given by other authors (Carrier et al., 2011; Chen et al., 2011; Slopiecka et al., 2012; Williams \& Besler, 1996; Zabaniotou et al., 2008), where hemicellulose was found to decompose until 380 ${ }^{\circ} \mathrm{C}$; and, from this point, the mass variation was assumed to correspond with charcoal degradation. Surprisingly, taking into account the simulated behaviour of each component, hemicellulose lasted until $450{ }^{\circ} \mathrm{C}$. So, the change in the mass variation tendency at $370{ }^{\circ} \mathrm{C}$ was caused by a higher amount of charcoal in the sample rather than a total fading of the hemicellulose once this temperature had been reached. At higher temperatures, the mass reduction was related to the charcoal breaking reaction.

As we can see in Figure 3, the proposed model can simulate the degradation of the biomass components. This simulation of each component is a good tool due to the fact that it provides a way to ensure that the simulation has a physical sense. Thus, it can be easily checked if each individual behaviour agrees with the experimental data. 


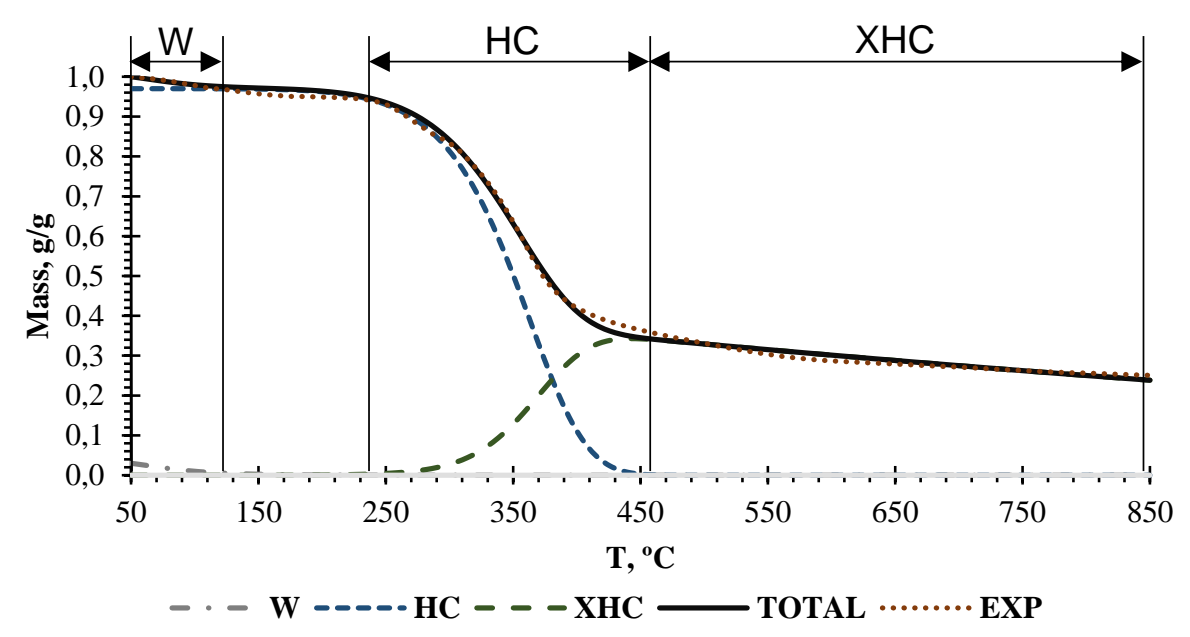

Figure 3. Fitting for the hemicellulose decomposition with a heating rate of $20{ }^{\circ} \mathrm{C} / \mathrm{min}$. W: Water. HC: Hemicellulose. XHC: Char of hemicellulose. TOTAL: Simulated TGA. EXP: Experimental TGA.

This analysis was completed with the simulated differential thermography (DTG) showed in Figure 4. It can be seen that there is a first minimum at $90{ }^{\circ} \mathrm{C}$ corresponding to the first slope change at $50^{\circ} \mathrm{C}$ in Figure 3 due to water evaporation. The second minimum, which appears at $346{ }^{\circ} \mathrm{C}$, is related with hemicellulose decomposition and it originates the second change in slope at $250{ }^{\circ} \mathrm{C}$. Furthermore, there is a maximum at $370{ }^{\circ} \mathrm{C}$ which represents the charcoal formation and implies the change in slope at $401{ }^{\circ} \mathrm{C}$. The combination (by addition) of all of these peaks gives a minimum at $362{ }^{\circ} \mathrm{C}$ which is the representative temperature of hemicellulose thermal degradation. This value does not agree with other authors. For example, Elyounssi, K. et al. (Elyounssi et al., 2012) and Slopiecka, K. et al. (Slopiecka et al., 2012) found that this peak is between $260-299^{\circ} \mathrm{C}$ at low heating rates and Williams, P. T. and Besler, S. (Williams \& Besler, 1996) discovered that it is around $310^{\circ} \mathrm{C}$ at $20 \mathrm{~K} / \mathrm{min}$. This decoupling could be caused by the fact that the value obtained in this work is for extracted hemicellulose and the others from complex samples. However, the temperature of the hemicellulose maximum in our woody biomass fittings $\left(304^{\circ} \mathrm{C}\right)$ agrees with the value of these authors (Figure 5). So, this deviation would show that the same compound in a different structure has a different behaviour against thermal degradation. Finally, the comparison between experimental and simulated DTG were done (Figure 6). Both curves presents the same behaviour, with the main variations at the same temperatures. The differences between them could come from the numerical evaluation of the experimental derivative, which is obtained by a central difference approximation. 


\section{Chapter 2}

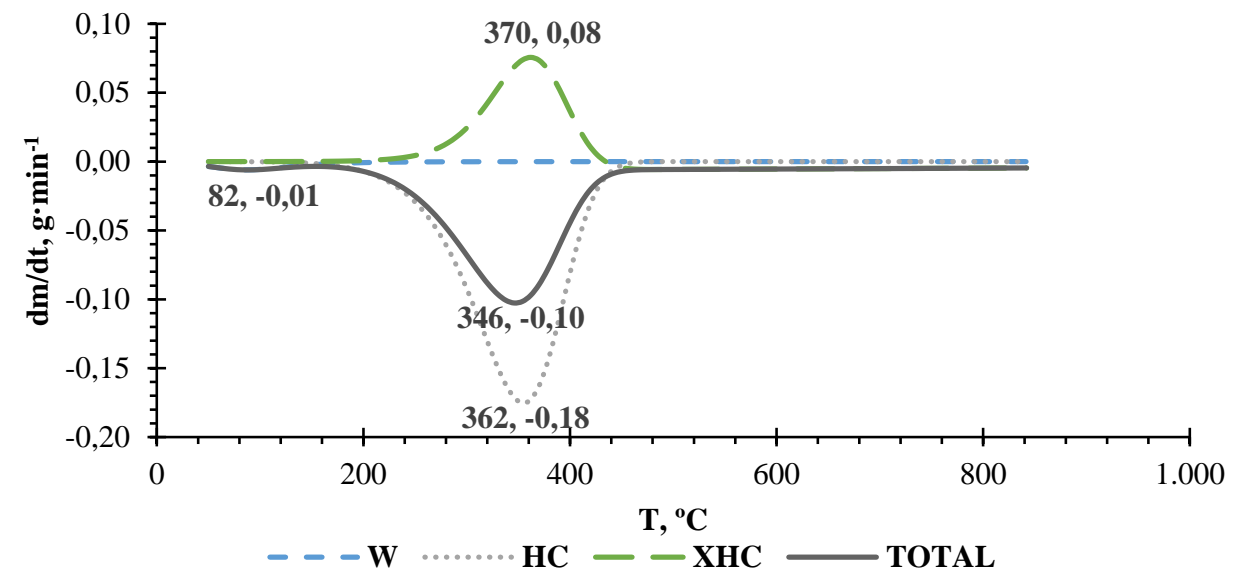

Figure 4. Simulated differential thermography of the hemicellulose TGA. W: Water. HC: Hemicellulose. XHC: Char of hemicellulose. TOTAL: Simulated DTG.

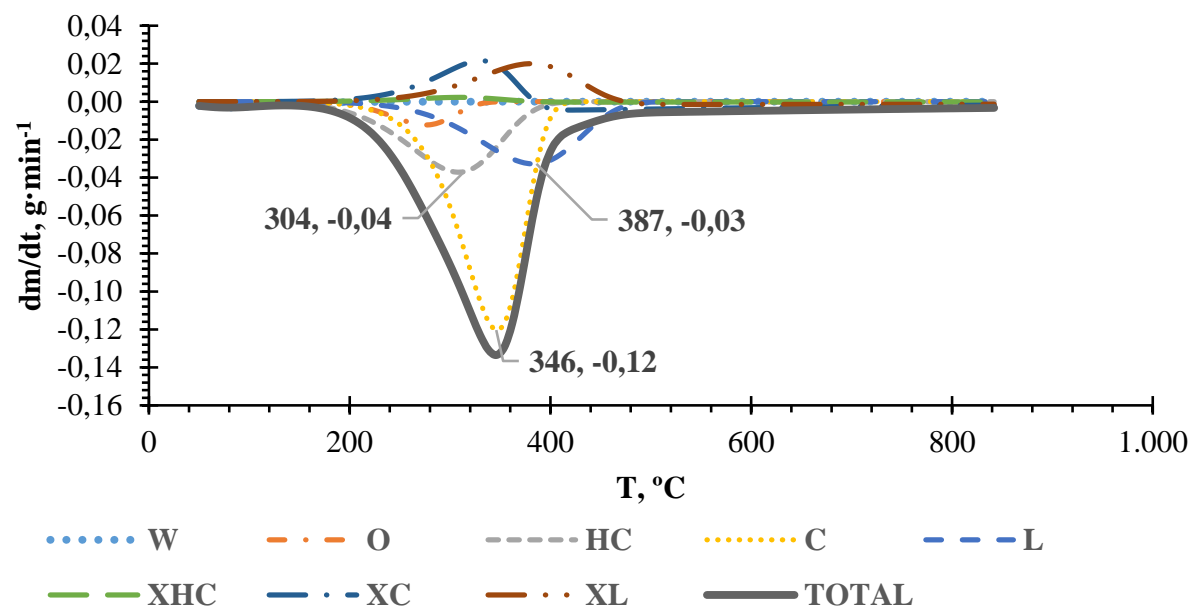

Figure 5. Simulated differential thermography of the lime TGA. W: Water. HC: Hemicellulose. XHC: Char of hemicellulose. TOTAL: Simulated DTG. O: Oil. C: Cellulose. L: Lignin. XC: Char of cellulose. XL: Char of lignin.

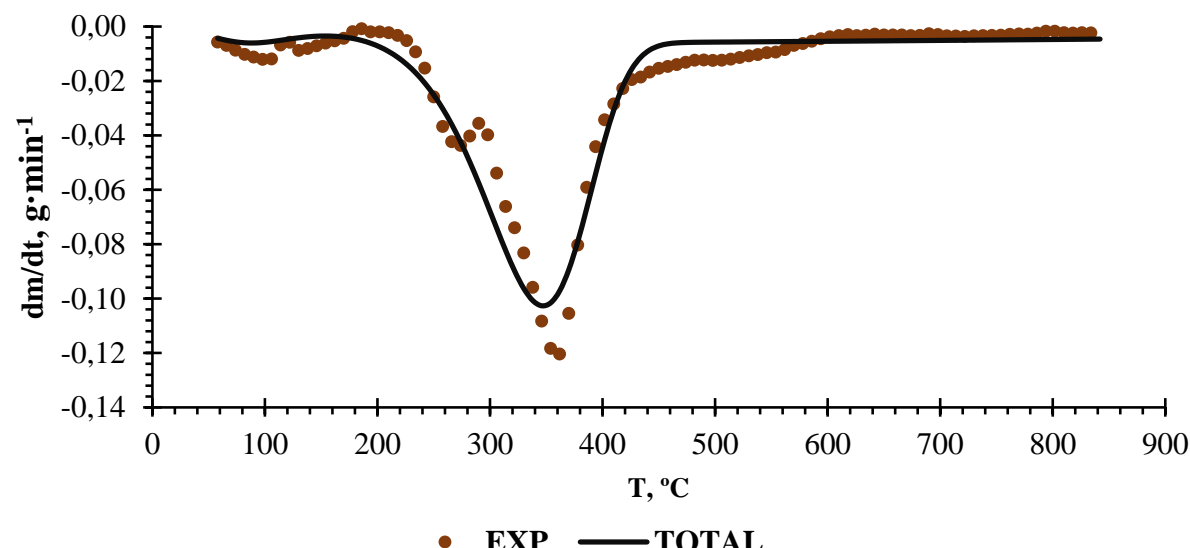

Figure 6. Simulated differential thermography and experimental differential thermography. EXP: Experimental DTG. TOTAL: Simulated DTG. 


\subsubsection{Cellulose}

The adjustment of the TGA of cellulose at heating rates of $20^{\circ} \mathrm{C} / \mathrm{min}$ (average absolute deviation of $6.6 \%$ ), $10{ }^{\circ} \mathrm{C} / \mathrm{min}$ (average absolute deviation of $3.7 \%$ ) and $5{ }^{\circ} \mathrm{C} / \mathrm{min}$ (average absolute deviation of $1.2 \%$ ) was done in this point. The obtained kinetic parameters are presented in Table 7 . The thermolysis process started at $300{ }^{\circ} \mathrm{C}$, with the fractionation of cellulose, and continued until $400{ }^{\circ} \mathrm{C}$. After this temperature, there was only charcoal in the sample. This experimental behaviour of cellulose agrees with the work of previous authors (Capart et al., 2004; Carrier et al., 2011; Chen et al., 2011; Slopiecka et al., 2012; Williams \& Besler, 1996; Zabaniotou et al., 2008) and it could be simulated using the same set of kinetics parameter for the three experiments.

A decoupling was observed in mass variation originated by the different heating rates: the lower the heating rate is, the higher yield of charcoal is obtained. The origin of this fluctuation could be that a slow heating rate provides enough time to appear secondary reactions which increase the charcoal production (Capart et al., 2004; Elyounssi et al., 2012; Van de Velden, 2010) due the collapse of the polymeric structure. For this reason, a specified model was proposed to cellulose decomposition (point 3.3). The idea was to represent this change in the decomposition process by a non-Arrhenius' dependence with temperature.

It is observed by the differential thermography of cellulose that its pure fraction shows a peak at $370{ }^{\circ} \mathrm{C}$. Again, it decreased to $346{ }^{\circ} \mathrm{C}$ in a woody sample (Figure 5). This last value is similar to the data provided by Williams, P. T. and Besler, S. (Williams \& Besler, 1996) and Carrier et al. (Carrier et al., 2011). Consequently, there is a modification in the thermal degradation of the cellulose when it is inside a complex sample due to the variation in structure.

\subsubsection{Lignin}

Both studied samples showed a similar behaviour that the previously described in the literature (Carrier et al., 2011; Chen et al., 2011; Slopiecka et al., 2012; Williams \& Besler, 1996; Zabaniotou et al., 2008), the reaction began around $200{ }^{\circ} \mathrm{C}$ with the cleavage of the lignin and went on until $500{ }^{\circ} \mathrm{C}$ when only charcoal remained in biomass. However, both lignin samples have some quantitative differences which did not allow to fit the experimental data with only one set of kinetic parameters. This discrepancy between them implies that it is very important how the biomass has been treated and how its structure 
is. The kinetic parameters from the adjustment of the lining from Turku (average absolute deviation of $1.7 \%$ ) and from the fitting of the alkaline lignin (average absolute deviation of $1.1 \%$ ) are listed in Table 7.

The differential thermogravimetric analysis of the lignin showed a minimum at $322{ }^{\circ} \mathrm{C}$ for its isolated fraction. This value was far from the value of $387^{\circ} \mathrm{C}$, which appeared in a woody sample (Figure 5) and from the value established by Williams, P. T. and Besler, S. (Williams \& Besler, 1996) $\left(390^{\circ} \mathrm{C}\right)$ or Carrier et al. (Carrier et al., 2011) $\left(395^{\circ} \mathrm{C}\right)$. This decoupling would be again caused by an effect of the structure of the sample.

\subsection{Complex samples}

In this section the TGA of complex samples was studied. The procedure was to try to simulate the experimental data from the TGA of complex samples with the kinetics parameters obtained for the pure fractions. Hence, only if this simulation had no correlation with the experimental performance, a new set of parameters would be searched.

\subsubsection{Grape seeds}

This section is focused in the TGA of wastes from the wine industry: seeds, extracted seeds, seed skins and hydrolysed seeds.

\subsubsection{No-extracted seeds and extracted seeds}

The TGA of the no-extracted seeds was fitted (average absolute deviation of 1.6\%) using the same kinetics parameters for the pure hemicellulose and cellulose and changing the parameters related with the lignin. This change implies that a relation between the three main components exit and justified the necessity of use a kinetic more complex than a first order kinetic to model the system. The used reaction pathway was the same as in pure samples.

The sample treated with a mixture of ethanol/water (70-30) for 1 hour could not be adjusted by the same parameters. Consequently, a new set of kinetics parameters was needed to its fitting (average absolute deviation of $1.1 \%$ ). Hence this experimentation is other proof of the structure of biomass has a role in its thermal degradation. This deviation 
$\left(\Delta K=\left(K_{N o-\text { Extracted }}-K_{\text {Extracted }}\right) / K_{\text {Extracted }}\right)$ can be observed in Figure 7 . In which it is presented that the extraction increases the degradation with temperature of the sample. The kinetic parameters are collected in Table 7.

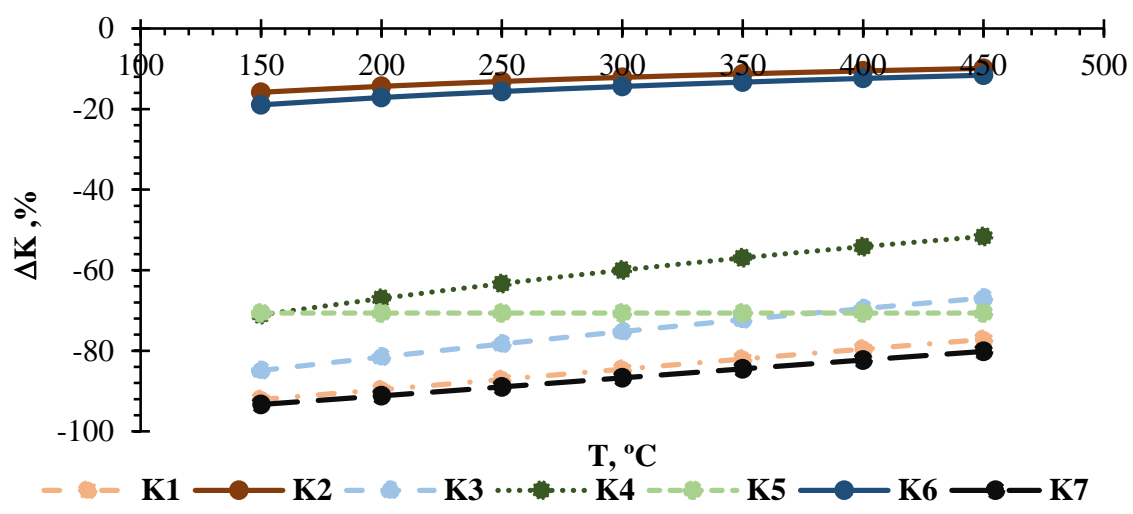

Figure 7. Variation of the kinetic constants between the extracted seeds and the no extracted seeds. K1: kinetic constant of hemicellulose degradation to volatiles. K2: kinetic constant of cellulose degradation to volatiles. K3: kinetic constant of lignin degradation to volatiles. K4: kinetic constant of lignin degradation to char. K5: kinetic constant of lignin char degradation to volatiles. K6: kinetic constant of cellulose degradation to char. K7: kinetic constant of hemicellulose degradation to char.

It is shown in Figure 7 that the reactions more affected by the extraction are the degradation of the hemicellulose (K1 and K7) and lignin (K3, K4 and K5). Cellulose (K2 and K6) decomposition is also increased but around 50\% less. These results would be coherent with the expected behaviour due to the fact that lignin encloses cellulose and hemicellulose and it would be the most exposed. Regarding hemicellulose, it was expected that this process enhances its thermal breaking because it is water soluble. K8 and K9 (kinetic constant of cellulose and hemicellulose char degradation to volatiles respectively) were not affected. This result could be explained because the main contribution to the char comes from the lignin. It is also interesting the fact that the higher the degradation temperature is, the lower effect has the pre-treatment. Which would be expected because temperature enhances exponentially thermal degradation.

\subsubsection{Grape skin}

The main characteristic of this sample is that it does not have lignin. For this reason, the model had to reproduce the experimental behaviour using only the parameters related with hemicellulose and cellulose (Table 7). The model represents well the process (average absolute deviation of $1.9 \%$ ) but there is a dramatic change of slope at $275^{\circ} \mathrm{C}$ that cannot simulate. In addition, it needed a change in the kinetics parameters which could be explained again by the effect of the biomass structure. 


\subsubsection{Hydrolysed samples}

As we mentioned before, the grape seeds suffered for 1 hour three different hydrolysis processes at temperatures of $250{ }^{\circ} \mathrm{C}, 300{ }^{\circ} \mathrm{C}$ and $340{ }^{\circ} \mathrm{C}$. The result was a substance partially degraded with high content of charcoal. These three degraded samples were used in a TGA whose results were fitted with only a set of parameters (Table 7) with an average absolute deviation of $1.1 \%$ at $250{ }^{\circ} \mathrm{C}, 0.86 \%$ at $300{ }^{\circ} \mathrm{C}$ and $0.68 \%$ at $340{ }^{\circ} \mathrm{C}$. This previous degradation generates a material which higher resistance against thermal degradation due to the fact that some charcoal was formed. This statement is shown in Figure 8, where the variation is defined by the following mathematical expression $\Delta K=$ $\left(K_{N o-H y d r o l y z e d}-K_{\text {Hydrolyzed }}\right) / K_{\text {Hydrolyzed }}$. It exhibits that the kinetics decrease respect the non-treated samples. However, hemicellulose kinetics presents the opposite behaviour but it is not representative because the main part of hemicellulose disappear during the hydrolysis.

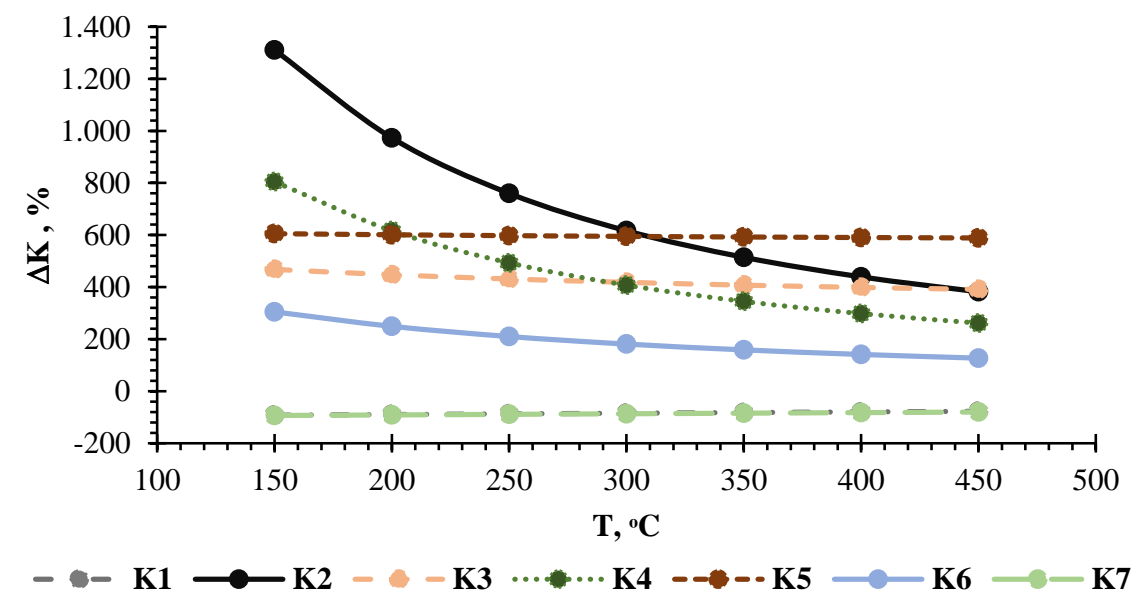

Figure 8. Variation of the kinetic constantan between the hydrolysed seeds and the non- hydrolysed seeds. K1: kinetic constant of hemicellulose degradation to volatiles. K2: kinetic constant of cellulose degradation to volatiles. K3: kinetic constant of lignin degradation to volatiles. K4: kinetic constant of lignin degradation to char. K5: kinetic constant of lignin char degradation to volatiles. K6: kinetic constant of cellulose degradation to char. K7: kinetic constant of hemicellulose degradation to char.

The lignin kinetic variations observed in Figure 8 could be justified again with its protection function like in part 4.2.1.1. On the other hand, cellulose shows in this case a higher modification in kinetics due to their degradation during the hydrolysis. Finally, temperature reduce again the differences between the thermal degradation of both samples. K8 and K9 do not appear because of their low contribution to the total char. 


\section{Chapter 2}

\subsubsection{Woody biomass}

In this point, the thermal decomposition in isothermal and no isothermal conditions of woody biomass is considered. All the fittings needed a modification in the kinetics parameters.

\subsubsection{Non-isothermal process}

Using the parameters obtained from the grape seeds the wood degradation could not be directly simulated because it has a different structure. The experimental data were divided in several groups depending on its lignin content (Table 4) to can use the same parameters for each group (Table 7). This division shows that a difference in the composition implies a change in the decomposition too. This could be explained by an interaction between the species in the wood, so when a greater amount of lignin exits the breaking of cellulose into volatiles and its charcoal formation are reduced and the degradation into volatiles of the later too. In addition, a higher production of volatiles from lignin and degradation into charcoal is achieved (Figure 9, $\left.\Delta K=\left(K_{10 \%}-K_{20 \%}\right) / K_{20 \%}\right)$. However, with a content of lignin greater than $30 \%$ the kinetics evolution changes. The kinetics of the cellulosic part of sample continues decreasing with the amount of lignin but the kinetics related to lignin decreases too. This behaviour could be caused by an increment in the thermal degradation resistance of the sample due to the fact that lignin, which is the strongest component against thermal degradation, would be more than $30 \%$.

Table 4. Groups of woody samples taking into account its lignin content.

\begin{tabular}{|c|c|c|}
\hline $\begin{array}{l}\text { Lignin content } \\
\text { (wt } \%)\end{array}$ & Samples & $\begin{array}{c}\text { A.A.D. }{ }^{a} \\
(\%)\end{array}$ \\
\hline \multicolumn{3}{|l|}{20} \\
\hline & Lime & 1.97 \\
\hline \multicolumn{3}{|l|}{26} \\
\hline & Plane tree & 1.46 \\
\hline & Catalpa & 1.87 \\
\hline \multicolumn{3}{|l|}{30} \\
\hline & Holm oak & 1.82 \\
\hline \multicolumn{3}{|l|}{$>30$} \\
\hline & Cedar & 1.52 \\
\hline & Acer Saccharum & 2.14 \\
\hline & Almond & 4.31 \\
\hline
\end{tabular}




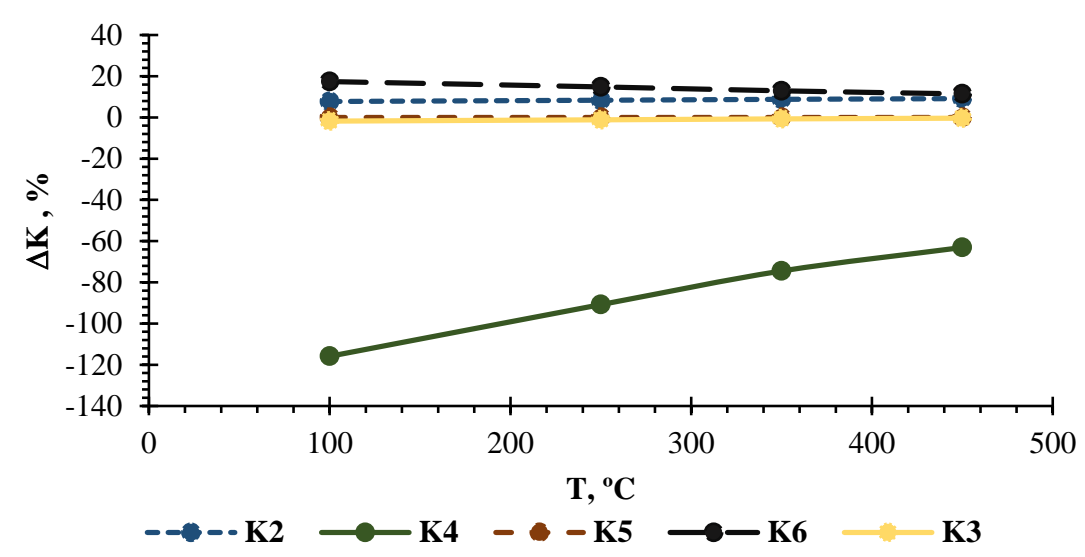

Figure 9. Variation in percentage of the reaction kinetics between the samples between $26 \%$ and $30 \%$ of lignin. K2: kinetic constant of cellulose degradation to volatiles. K3: kinetic constant of lignin degradation to volatiles. K4: kinetic constant of lignin degradation to char. K5: kinetic constant of lignin char degradation to volatiles. K6: kinetic constant of cellulose degradation to char.

It is remarkable that kinetic constants related with hemicellulose degradation do no change their values (for this reason they are not present in Figure 9). This result could be explained by the fact that in this study case there were not previous factors that can solve it. So, its interactions with cellulose and lignin would be independent to the lignin concentration. The role of the temperature is the same as in parts 4.2.1.1 and 4.2.1.3 and $\mathrm{K} 8$ is not represented because there is no change in its value.

\subsubsection{Isothermal process}

Finally, the TGA of a sample of Acer Saccharum was studied in isothermal conditions at $150,200,250,300$ and $350{ }^{\circ} \mathrm{C}$. The adjustment needed a set of parameters for each temperature, when it is higher than $200{ }^{\circ} \mathrm{C}$, and different from the parameters used in the non-isothermal process (Table 7). Their average absolute deviations were: $0.71 \%, 0.70$ $\%, 0.39 \%, 0.63 \%$ and $2.68 \%$, respectively. This discrepancy between the kinetics due to the type of process could be caused by a protective interaction between species. This means that, in an isothermal mode, the decomposition is low up to a certain temperature is reached $\left(250^{\circ} \mathrm{C}\right)$ and hemicellulose degradation starts enhancing the decomposition of cellulose and lignin. Besides, there is an enhanced in lignin degradation $300{ }^{\circ} \mathrm{C}$, when cellulose would start its degradation. This idea could explain the drastic change in the kinetics constants shown in Figure 10 at $250{ }^{\circ} \mathrm{C}$ and $300{ }^{\circ} \mathrm{C}$. 


\section{Chapter 2}
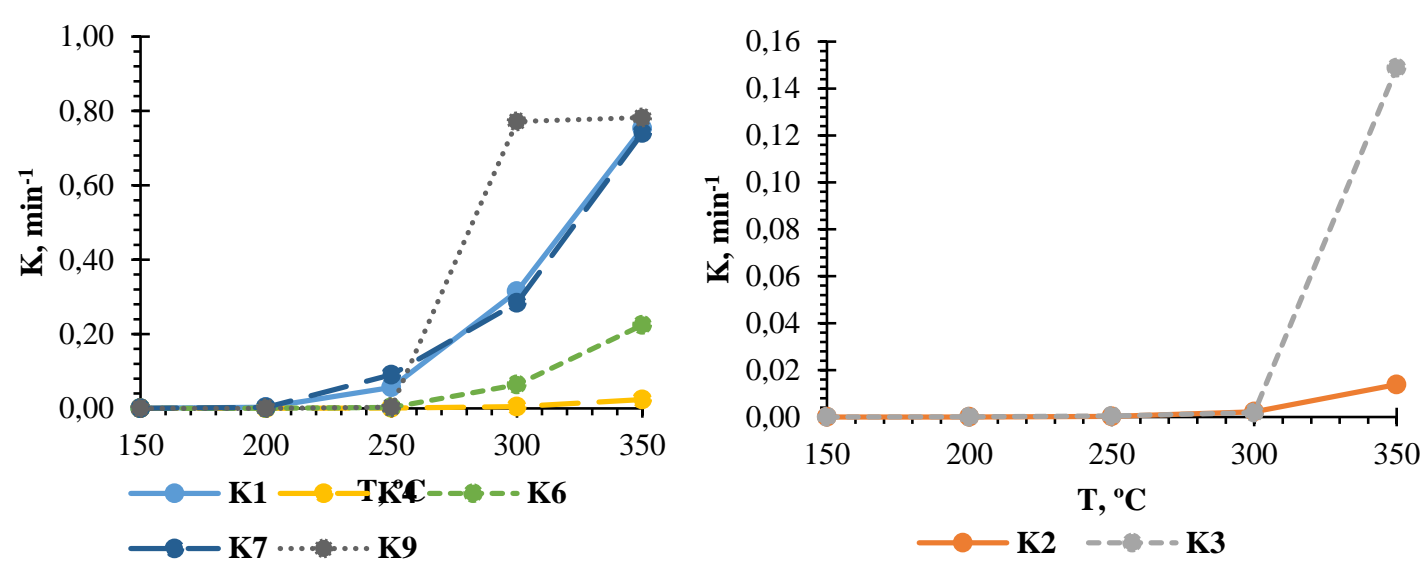

Figure 10. Kinetic constant in each isothermal process. K1: kinetic constant of hemicellulose degradation to volatiles. K2: kinetic constant of cellulose degradation to volatiles. K3: kinetic constant of lignin degradation to volatiles. K4: kinetic constant of lignin degradation to char. K6: kinetic constant of cellulose degradation to char. K7: kinetic constant of hemicellulose degradation to char. K9: kinetic constant of hemicellulose char degradation to volatiles.

It can be seen in Figure 10 that the thermal degradation at isothermal conditions depends on temperature strongly (as it was expected). In this case $\mathrm{K} 5$ and $\mathrm{K} 8$ are not present in the graph, because they did not change. This would be caused by the fact that the maximum operational temperature $\left(350^{\circ} \mathrm{C}\right)$ is not high enough to break lignin or cellulose char.

\subsection{Composition estimation}

Once all the experimental data have been adjusted, the capability of the model to estimate the initial composition of the biomass was tested. The sample used to try this estimation was the TGA of non-extracted grape seeds.

The prediction implies an optimization problem in which the difference between the experimental and simulated TGA must be minimized changing the values of the initial composition (Eq. ( 12 )). The problem was limited by the following restraints. It was assumed that there is not initial charcoal in the sample and that the initial composition of water, oil, hemicellulose, cellulose and lignin were in the ranges showed in the Table 5. The amount of inert compounds was obtained by balance to the total.

$$
\min _{m_{j}}\left(\sum_{t=0}^{t=t_{f}}\left|M_{E x p}-M\right|\right) ; m_{j_{\min }}<m_{j}<m_{j_{\max }} ; j \in[1, N]
$$




\section{Chapter 2}

Table 5. Initial composition variation ranges for the composition estimation of no-extracted grape seeds.

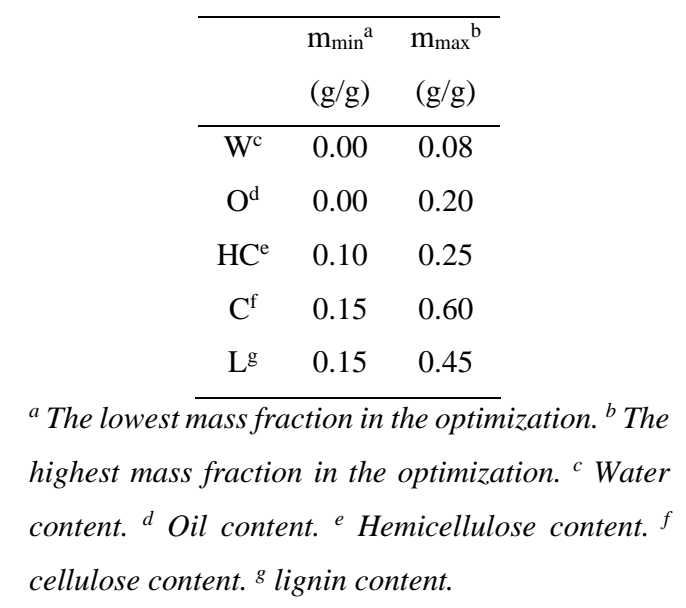

The calculated composition is not very accurate because in some compounds the deviation is high, for example the maximum deviation for water was $60.5 \%$ (Table 6). But taking into account that the values for the maximum and the minimum of each component were stablished in a general way, the prediction is good enough. In order to improve these values, more experimental compositions would be needed to fix a better optimization range. It is interesting that the calculated cellulose composition is closer to the experimental one than the hemicellulose composition. This result could be caused by the fact that the oil vaporization and hemicellulose degradation can appear both between $250{ }^{\circ} \mathrm{C}$ and $300^{\circ} \mathrm{C}$.

Table 6. Comparison between the estimated and experimental composition of no-extracted grape seeds.

\begin{tabular}{ccccccc}
\hline & $\mathrm{W}^{\mathrm{a}}$ & $\mathrm{O}^{\mathrm{b}}$ & $\mathrm{HC}^{\mathrm{c}}$ & $\mathrm{C}^{\mathrm{d}}$ & $\mathrm{L}^{\mathrm{e}}$ & $\mathrm{in}^{\mathrm{f}}$ \\
\hline $\mathrm{m}(\mathrm{wt} \%)^{\mathrm{g}}$ & & & & & & \\
Experimental & 0.0292 & 0.1655 & 0.1461 & 0.2142 & 0.4187 & 0.0263 \\
Estimated & 0.0469 & 0.1149 & 0.1887 & 0.2215 & 0.4121 & 0.0159 \\
Deviation $(\%)^{\mathrm{h}}$ & 60.5 & -30.6 & 29.2 & 3.39 & -1.57 & -39.5
\end{tabular}

${ }^{a}$ Water. ${ }^{b}$ Oil. ${ }^{c}$ Hemicellulose. ${ }^{d}$ Cellulose. ${ }^{e}$ Lignin. ${ }^{f}$ Inert. ${ }^{g}$ Biomass composition in weight percentage. ${ }^{h}$ Deviation between the estimated and real composition.

\section{Conclusions}

An auto-catalytic kinetic model has been developed for thermogravimetric analysis with an average absolute deviation between the simulation and the experimental data lower than $7 \%$ in all the studied cases. This model can simulate the behaviour of very different samples (seeds, grape skins and trees) as isothermal process as non-isothermal process providing the composition profiles of their individual components too. In addition, the model can reproduce the effect of the heating rate in the decomposition using a non- 


\section{Chapter 2}

Arrhenius' dependence with the temperature. Due to the fact that the kinetic parameters change with the type of biomass it is deduced that the structure of biomass has a very important role in thermal degradation. Also important is the composition because some species can work as a shield that avoids the degradation of the others until their cleavage start. Finally, a preliminary composition estimation was done, starting from a TGA curve and estimating the composition of the biomass material. This prediction has an acceptable accuracy especially for cellulose and lignin (differences lower than $7 \%$ ). However, the prediction of the essential oil is trick and in order to increase model fidelity, more experiments would be needed, which would allow to stablish better limits for the optimization ranges of the initial composition and to improve the kinetics parameters. 
Table 7. Kinetics parameters fitted for all the samples

\begin{tabular}{|c|c|c|c|c|c|c|c|c|c|c|c|c|c|c|c|c|c|c|}
\hline & ko1 & $\mathrm{kO}_{2}$ & ko3 & ko4 & ko5 & ko6 & ko7 & ko8 & ko9 & $\mathrm{Ea}_{1} / \mathrm{R}$ & $\mathrm{Ea}_{2} / \mathrm{R}$ & $\mathrm{Ea}_{3} / \mathrm{R}$ & $\mathrm{Ea}_{4} / \mathrm{R}$ & $\mathrm{Ea} / \mathrm{R}$ & $\mathrm{Ea} 6 / \mathrm{R}$ & $\mathrm{Ea} / \mathrm{R}$ & $\mathrm{Ea} 8 / \mathrm{R}$ & $\mathrm{Ea} / \mathrm{R}$ \\
\hline HEMICELLULOSE & 19,894 & - & - & - & - & - & 20,962 & - & 0.024 & 7,177 & - & - & - & - & - & 7,120 & - & 101 \\
\hline CELLULOSE & - & 5,976 & - & - & - & 32,613 & - & 0.014 & - & - & 12,190 & - & - & - & 8,658 & - & 274 & - \\
\hline $\begin{array}{c}\text { LIGNIN (TURKU) } \\
\text { LIGNIN }\end{array}$ & - & - & 48,433 & 48,857 & 0.013 & - & - & - & - & - & - & 8,308 & 8,192 & 481 & - & - & - & - \\
\hline $\begin{array}{c}\text { (ALKALINE) } \\
\text { NO EXTRACTED }\end{array}$ & - & - & 33,297 & 14,151 & 0.012 & - & - & - & - & - & - & 7,579 & 6,482 & 122 & - & - & - & - \\
\hline $\begin{array}{l}\text { SEEDS } \\
\text { EXTRACTED }\end{array}$ & 19,894 & 5,976 & 48,594 & 47,982 & 0.015 & 32,613 & 20,962 & 0.014 & 0.024 & 7,177 & 12,190 & 9,337 & 8,936 & 100 & 8,658 & 7,120 & 274 & 101 \\
\hline $\begin{array}{c}\text { SEEDS } \\
\text { HYDROLYSED }\end{array}$ & 19,580 & 6,023 & 48,619 & 48,046 & 0.045 & 32,629 & 22,726 & 0.014 & 0.024 & 6,097 & 12,120 & 8,677 & 8,438 & 100 & 8,570 & 6,009 & 274 & 101 \\
\hline SEEDS & 19,580 & 5,648 & 12,148 & 48,415 & 0.002 & 32,480 & 22,726 & 0.014 & 0.024 & 6,097 & 13,286 & 9,625 & 9,898 & 124 & 9,248 & 6,009 & 274 & 101 \\
\hline GRAPE SKIN & 17,621 & 4,221 & - & - & - & 40,014 & 21,272 & 0.021 & 0.067 & 6,049 & 12,269 & - & - & - & 7,505 & 6,584 & 104 & 103 \\
\hline TREES-20 \% & 39,194 & 44,605 & 48,812 & 48,191 & 0.018 & 30,071 & 7,120 & 0.078 & 0.024 & 6,755 & 11,127 & 8,503 & 8,104 & 100 & 7,798 & 7,320 & 274 & 101 \\
\hline TREES-26 \% & 39,194 & 43,605 & 48,812 & 48,191 & 0.018 & 30,071 & 7,120 & 0.078 & 0.024 & 6,755 & 11,127 & 8,203 & 8,004 & 100 & 7,998 & 7,320 & 274 & 101 \\
\hline TRESS-30 \% & 39,194 & 38,595 & 47,812 & 48,202 & 0.018 & 30,071 & 7,120 & 0.078 & 0.024 & 6,755 & 11,105 & 8,183 & 7,602 & 100 & 8,098 & 7,320 & 274 & 101 \\
\hline TREES->30 \% & 39,194 & 27,580 & 46,988 & 46,970 & 0.036 & 29,653 & 7,120 & 0.082 & 0.024 & 6,755 & 10,934 & 8,870 & 8,227 & 100 & 9,162 & 7,320 & 274 & 101 \\
\hline ISOTHERMAL & - & - & - & - & - & - & - & - & - & - & - & - & - & - & - & - & - & - \\
\hline $150-200{ }^{\circ} \mathrm{C}$ & 17,028 & 38,652 & 8,120 & 6,016 & 0.000 & 33,233 & 43,823 & 0.013 & 0.000 & 7,295 & 13,210 & 8,770 & 8,060 & 121 & 8,544 & 7,866 & 390 & 100 \\
\hline $250^{\circ} \mathrm{C}$ & 16,973 & 38,652 & 8,120 & 6,016 & 0.000 & 33,233 & 43,825 & 0.013 & 0.004 & 7,295 & 13,210 & 8,770 & 8,060 & 121 & 8,544 & 7,866 & 390 & 100 \\
\hline $300{ }^{\circ} \mathrm{C}$ & 16,525 & 38,652 & 8,120 & 6,016 & 0.001 & 33,233 & 43,825 & 0.013 & 0.918 & 6,597 & 13,210 & 8,770 & 8,060 & 121 & 8,544 & 6,847 & 390 & 100 \\
\hline $350^{\circ} \mathrm{C}$ & 16,525 & 34,637 & 10,144 & 6,155 & 0.001 & 40,573 & 43,825 & 0.013 & 0.918 & 6,229 & 13,210 & 8,770 & 8,060 & 121 & 7,544 & 6,847 & 390 & 100 \\
\hline
\end{tabular}




\begin{tabular}{ccccccccccc}
\hline & $\beta_{1}$ & $\beta_{2}$ & $\beta_{3}$ & $\beta_{4}$ & $\beta_{5}$ & $\beta_{6}$ & $\beta_{7}$ & $\beta_{8}$ & $\beta_{9}$ & $\mathrm{c}$ \\
\hline HEMICELLULOSE & 0.0000 & - & - & - & - & - & 0.7700 & - & 0.5200 & - \\
CELLULOSE & - & 0.5300 & - & - & - & 0.0000 & - & 1.1300 & - & 0.0060 \\
LIGNIN (TURKU) & - & - & 0.0000 & 0.0000 & 0.0000 & - & - & - & - & - \\
LIGNIN (ALKALINE) & - & - & 0.0000 & 0.0000 & 0.0000 & - & - & - & - & - \\
NO EXTRACTED SEEDS & 0.0000 & 0.5300 & 0.0000 & 0.1100 & 1.9200 & 0.0000 & 0.7700 & 1.1300 & 0.5200 & 0.0060 \\
EXTRACTED SEEDS & 0.0050 & 0.5300 & 0.0000 & 0.1000 & 1.9100 & 0.0000 & 0.7600 & 1.1300 & 0.5200 & 0.0060 \\
HYDROLYSED SEEDS & 0.0050 & 0.5300 & 0.0000 & 0.1000 & 1.9100 & 0.0000 & 0.7600 & 1.1300 & 0.5200 & 0.0060 \\
GRAPE SKIN & 0.0050 & 0.0714 & - & - & - & 0.1021 & 0.0152 & 0.0079 & 0.0134 & 0.0040 \\
TREES-20\% & 0.6584 & 0.7149 & 0.0017 & 0.1068 & 1.9150 & 0.0000 & 0.7680 & 1.1309 & 0.5192 & 0.0001 \\
TREES-26\% & 0.6584 & 0.7149 & 0.0017 & 0.1068 & 1.9150 & 0.0000 & 0.7680 & 1.1309 & 0.5192 & 0.0001 \\
TRESS-30\% & 0.6584 & 0.7163 & 0.0017 & 0.1062 & 1.9150 & 0.0000 & 0.7680 & 1.1309 & 0.5192 & 0.0001 \\
TREES->30\% & 0.6584 & 0.7163 & 0.0017 & 0.1062 & 1.9150 & 0.0000 & 0.7680 & 1.1309 & 0.5192 & 0.0001 \\
ISOTHERMAL & - & - & - & - & - & - & - & - & - & - \\
$150-200{ }^{\circ} \mathrm{C}$ & 0.6584 & 0.7149 & 0.0017 & 0.1068 & 1.9150 & 0.0000 & 0.7680 & 1.1309 & 0.5192 & 0.0037 \\
$250{ }^{\circ} \mathrm{C}$ & 0.6584 & 0.7149 & 0.0017 & 0.1068 & 1.9150 & 0.0000 & 0.7680 & 1.1309 & 0.5192 & 0.0037 \\
$300{ }^{\circ} \mathrm{C}$ & 0.6584 & 0.7149 & 0.0017 & 0.1068 & 1.9150 & 0.0000 & 0.7680 & 1.1309 & 0.5192 & 0.0037 \\
$350{ }^{\circ} \mathrm{C}$ & 0.6584 & 0.7149 & 0.0017 & 0.1068 & 1.9150 & 0.0000 & 0.7680 & 1.1309 & 0.5192 & 0.0037 \\
\hline
\end{tabular}




\section{Chapter 2}

\section{Nomenclature}

Acronyms

C: Cellulose.

HC: Hemicellulose.

L: Lignin.

O: Oil.

TGA: Thermogravimetric analysis.

W: Water.

XC: Charcoal produced form cellulose.

XHC: Charcoal produced form hemicellulose.

XL: Charcoal produced form lignin.

Subindex and superindex

EXP: Experimental data of the TGA.

in: inert compounds.

TOTAL: Total simulated TGA.

Greek letters and symbols

$\alpha_{i}$ : Initialization factor, dimensionless.

$\beta_{i}$ : Acceleration factor, dimensionless.

$A_{j}-F_{j}$ : Antoine's equation coefficients of the compound " $\mathrm{j}$ ”, dimensionless.

$c$ : Correction factor for the kinetic in the decomposition at different heating rates of the cellulose, dimensionless.

$C_{j}$ : Concentration of " $\mathrm{j}$ " in the gas phase, $\mathrm{kmol} / \mathrm{m}^{3}$.

$C_{j}^{*}$ : Equilibrium concentration of " $\mathrm{j}$ " in the interphase between the liquid and the gas phase, $\mathrm{kmol} / \mathrm{m}^{3}$.

$\frac{E_{a_{i}}}{R}:$ Activation energy of the reaction "i", $\mathrm{K}$.

$h$ : Partial mass transfer coefficient between the liquid and the gas, $\mathrm{kg}_{\mathrm{j}} \cdot \mathrm{m}^{3} / \mathrm{min} \cdot \mathrm{m}^{2} \cdot \mathrm{kmol}_{\mathrm{j}}$. $k_{o_{i}}$ : Preexponential factor for the reaction " $\mathrm{i}$ ", $\min ^{-1}$.

$k_{i}$ : Kinetic constant for the reaction "i", $\min ^{-1}$.

$M_{\text {exp }}$ : Experimental mass fraction of unreacted biomass, $\mathrm{g}_{\text {sample }} / \mathrm{g}_{\text {sample initial. }}$

$M$ : Mass fraction of unreacted biomass, $\mathrm{g}_{\text {sample }} / \mathrm{g}_{\text {sample initial. }}$

$m_{j_{\text {max }}}$ : Maximun value for mass fraction of the compound " $\mathrm{j}$ " in the biomass, $\mathrm{g} / \mathrm{g}$.

$m_{j_{m i n}}$ : Minimum value for mass fraction of the compound " $\mathrm{j}$ " in the biomass, $\mathrm{g} / \mathrm{g}$. 


\section{Chapter 2}

$m_{j}$ : Mass fraction of the compound " $\mathrm{j}$ " in the biomass, $\mathrm{g} / \mathrm{g}$.

$N$ : Number of compounds in the biomass, dimensionless.

$n_{i}$ : order of reaction of the reaction " $\mathrm{i}$ ", dimensionless.

$n l_{i}$ : Mass transfer order, dimensionless.

$N_{r}$ : Number of reactions, dimensionless.

$P_{j}^{*}$ : Vapour pressure of the compound “j”, atm.

$r_{i}$ : Reaction velocity number "ij", g/min.g.

$r_{j}$ : Reaction velocity of decomposition for the component " $\mathrm{j}$ " in the biomass, $\mathrm{g} / \mathrm{min} \cdot \mathrm{g}$.

$S$ : Exchange surface between the liquid and the gas, $\mathrm{m}^{2}$.

t: Operating time, min.

$T$ : Operating temperature, $\mathrm{K}$.

$\boldsymbol{x}_{\boldsymbol{i}_{\boldsymbol{e x p}}}$ : Experimental biomass fraction, $\mathrm{g}_{\text {sample }} / \mathrm{g}_{\text {sample initial. }}$

$\boldsymbol{x}_{\boldsymbol{i} \boldsymbol{S I M}}$ : Simulated biomass fraction, $\mathrm{g}_{\text {sample }} / \mathrm{g}_{\text {sample initial. }}$

\section{Acknowledgements}

The authors acknowledge the Spanish Economy and Competitiveness Ministry, Project Reference: ENE2012-33613 and the regional government (Junta de Castilla y León), Project Reference: VA330U13 for funding. The authors would like to thank Prof. Pedro Fardim and Dr. Konstantin Gabov from Åbo Akademi for their help with the hydrotropic lignin.

\section{References}

Bobleter, O. 1994. Hydrothermal degradation of polymers derived from plants. Prog Polym Sci, 19, 797-841.

Bozell, J.J. 2008. Feedstocks for the future - Biorefinery production of chemicals from renewable carbon. Clean - Soil, Air, Water, 36(8), 641-647.

Capart, R., Khezami, L., Burnham, A.K. 2004. Assessment of various kinetic models for the pyrolysis of a microgranular cellulose. Thermochimica Acta, 417(1), 79-89.

Carrier, M., Loppinet-Serani, A., Denux, D., Lasnier, J.-M., Ham-Pichavant, F., Cansell, F., Aymonier, C. 2011. Thermogravimetric analysis as a new method to determine the lignocellulosic composition of biomass. Biomass and Bioenergy, 35(1), 298307. 


\section{Chapter 2}

Clark, J.H., Budarin, V., Deswarte, F.E.I., Hardy, J.J.E., Kerton, F.M., Hunt, A.J., Luque, R., Macquarrie, D.J., Milkowski, K., Rodriguez, A., Samuel, O., Tavener, S.J., White, R.J., Wilson, A.J. 2006. Green chemistry and the biorefinery: A partnership for a sustainable future. Green Chemistry, 8(10), 853-860.

Chen, Q., Zhou, J.S., Liu, B.J., Mei, Q.F., Luo, Z.Y. 2011. Influence of torrefaction pretreatment on biomass gasification technology. Chinese Science Bulletin, 56(14), 1449-1456.

Cheng, S., Zhu, S. 2009. Lignocellulosic feedstock biorefinery-the future of the chemical and energy industry. BioResources, 4(2), 456-457.

Elyounssi, K., Collard, F.X., Mateke, J.A.N., Blin, J. 2012. Improvement of charcoal yield by two-step pyrolysis on eucalyptus wood: A thermogravimetric study. Fuel, 96, 161-167.

Kastanaki, E., Vamvuka, D., Grammelis, P., Kakaras, E. 2002. Thermogravimetric studies of the behavior of lignite-biomass blends during devolatilization. Fuel Processing Technology, 77-78(0), 159-166.

Lv, D., Xu, M., Liu, X., Zhan, Z., Li, Z., Yao, H. 2010. Effect of cellulose, lignin, alkali and alkaline earth metallic species on biomass pyrolysis and gasification. Fuel Processing Technology, 91(8), 903-909.

Mangut, V., Sabio, E., Gañán, J., González, J.F., Ramiro, A., González, C.M., Román, S., Al-Kassir, A. 2006. Thermogravimetric study of the pyrolysis of biomass residues from tomato processing industry. Fuel Processing Technology, 87(2), 109-115.

Meng, L.Y., Kang, S.M., Zhang, X.M., Wu, Y.Y., Xu, F., Sun, R.C. 2012. Fractional pretreatment of hybrid poplar for accelerated enzymatic hydrolysis: Characterization of cellulose-enriched fraction. Bioresource Technology, 110, 308-313

Press, W., Teukolsky, S., Vetterling, W., Flannery, B. 2007. Numerical recipes 3rd edition: The art of scientific computing.

S. Völker, T.R. 2002. Thermokinetic investigation of cellulose pyrolysis. Impact of initial and final mass of kinetics results. Journal of Analytical and Applied Pyrolysis, 62, 165-177.

Slopiecka, K., Bartocci, P., Fantozzi, F. 2012. Thermogravimetric analysis and kinetic study of poplar wood pyrolysis. Applied Energy, 97, 491-497. 


\section{Chapter 2}

Van de Velden, M., Baeyens, J., Brems, A., Janssens, B., Dewil, R. 2010. Fundamentals, kinetics and endothermicity of the biomass pyrolysis reaction. Renewable Energy, $35(1), 232-242$.

Williams, P.T., Besler, S. 1996. The Influence of Temperature and Heating Rate on the Slow Pyrolysis of Biomass. Renewable Energy, 7(3), 233-250.

Zabaniotou, A., Ioannidou, O., Antonakou, E., Lappas, A. 2008. Experimental study of pyrolysis for potential energy, hydrogen and carbon material production from lignocellulosic biomass. International Journal of Hydrogen Energy, 33(10), 24332444.

\section{List of tables}

Table 1. Initial composition of the samples.

Table 2. Antoine's equation coefficients of water (W) and oil (O).

Table 3. Averaged mass transfer parameters of water $(\mathrm{W})$ and oil $(\mathrm{O})$.

Table 4. Groups of woody samples taking into account its lignin content.

Table 5. Initial composition variation ranges for the composition estimation of noextracted grape seeds.

Table 6. Comparison between the estimated and experimental composition of noextracted grape seeds.

Table 7. Kinetic parameters fitted for all the samples.

\section{List of figures}

Figure 1. Schema of the biomass structure.

Figure 2. Reaction pathway in a thermal decomposition.

Figure 3. Fitting for the hemicellulose decomposition with a heating rate of $20^{\circ} \mathrm{C} / \mathrm{min}$. W: Water. HC: Hemicellulose. XHC: Char of hemicellulose. TOTAL: Simulated TGA. EXP: Experimental TGA.

Figure 4. Simulated differential thermography of the hemicellulose TGA. W: Water. HC: Hemicellulose. XHC: Char of hemicellulose. TOTAL: Simulated DTG. 
Figure 5. Simulated differential thermography of the lime TGA. W: Water. HC: Hemicellulose. XHC: Char of hemicellulose. TOTAL: Simulated DTG. O: Oil. C: Cellulose. L: Lignin. XC: Char of cellulose. XL: Char of lignin.

Figure 6. Simulated differential thermography and experimental differential thermography. EXP: Experimental DTG. TOTAL: Simulated DTG.

Figure 7. Variation of the kinetic constants between the extracted seeds and the no extracted seeds. K1: kinetic constant of hemicellulose degradation to volatiles. K2: kinetic constant of cellulose degradation to volatiles. K3: kinetic constant of lignin degradation to volatiles. K4: kinetic constant of lignin degradation to char. K5: kinetic constant of lignin char degradation to volatiles. K6: kinetic constant of cellulose degradation to char. K7: kinetic constant of hemicellulose degradation to char.

Figure 8. Variation of the kinetic constantan between the hydrolysed seeds and the nonhydrolysed seeds. K1: kinetic constant of hemicellulose degradation to volatiles. K2: kinetic constant of cellulose degradation to volatiles. K3: kinetic constant of lignin degradation to volatiles. K4: kinetic constant of lignin degradation to char. K5: kinetic constant of lignin char degradation to volatiles. K6: kinetic constant of cellulose degradation to char. K7: kinetic constant of hemicellulose degradation to char.

Figure 9. Variation in percentage of the reaction kinetics between the samples between $26 \%$ and $30 \%$ of lignin. K2: kinetic constant of cellulose degradation to volatiles. K3: kinetic constant of lignin degradation to volatiles. K4: kinetic constant of lignin degradation to char. K5: kinetic constant of lignin char degradation to volatiles. K6: kinetic constant of cellulose degradation to char.

Figure 10. Kinetic constant in each isothermal process. K1: kinetic constant of hemicellulose degradation to volatiles. K2: kinetic constant of cellulose degradation to volatiles. K3: kinetic constant of lignin degradation to volatiles. K4: kinetic constant of lignin degradation to char. K6: kinetic constant of cellulose degradation to char. K7: kinetic constant of hemicellulose degradation to char. K9: kinetic constant of hemicellulose char degradation to volatiles. 
Chapter 3

CHAPTER 3 

Chapter 3

\title{
Pre-treatment effect on the thermal degradation of a feedstock with low hemicellulose content: Brazilian ginseng
}

Alvaro Cabezal, Diego T. Santos ${ }^{2}$, M. Angela A. Meireles ${ }^{2}$, Francisco Sobrón ${ }^{1}$, María José Cocero Alonso ${ }^{1}$ and Juan García-Serna ${ }^{1 *}$

${ }^{1}$ High Pressure Processes Group, Department of Chemical Engineering and Environmental Tech., University of Valladolid, Escuela de Ingenierías Industriales, (47011) Valladolid, Spain.; alvaro.cabeza.sanchez@gmail.com (A. C.), sobron@iq.uva.es (F.S.),mjcocero@iq.uva.es (M.J.C.A), jgserna@iq.uva.es (J.G-S.).

${ }^{2}$ LASEFI/DEA/FEA (School of Food Engineering)/UNICAMP (University of Campinas), Cidade Universitária “Zeferino Vaz”, R. Monteiro Lobato, 80, 13083-862 Campinas, SP, Brazil; diego_tresinari@yahoo.com.br (D.T.S), meireles@fea.unicamp.br (M.A.A.M) *Correspondence: jgserna@iq.uva.es; Tel.: +34-983-184-934

\section{DOI: $\underline{10.1021 / \text { acs.energyfuels.7b00695 }}$}

\begin{abstract}
Pyrolysis is a well-known process for biomass upgrading and a great deal of works are available about it. However, they focus on conventional lignocellulosic samples and the information about any other less common samples, but still valuable, is very difficult to find. For instance, Brazilian ginseng (Pfaffia glomerata) is a feedstock without hemicellulose and a profitable source of target compounds (like beta-ecdysone) by and extraction process, also generating and exhausted solid. However, there is not almost information about this biomass in bibliography. For this reason, this work deals for first time with the effect of different pretreatments on the thermal degradation behavior of the Brazilian ginseng. To do so, thermogravimetric analysis (TGA) of the raw material and post-treated samples were done in a synthetic air atmosphere (20\% oxygen). The thermograms were fitted by an autocatalytic model (deviation of $4.22 \%$ ) and the calculated kinetics were used to analyze how the pretreatment modifies the volatilization and char formation for each individual compound (cellulose and lignin) in all the samples. Additionally, structural changes were observed performing XRD and DSC, explaining why different kinetic parameters were required for each sample. Regarding XRD, a
\end{abstract}




\section{Chapter 3}

variable crystalline index that ranged from $51 \%$ to $75 \%$ was obtained. Concerning DSC, the pretreatment produced an endothermic peak between $150{ }^{\circ} \mathrm{C}$ and $200{ }^{\circ} \mathrm{C}$. .

Keywords: oxidative pyrolysis; thermogravimetric analysis; structure role; XRD; DSC; ginseng roots.

\section{Introduction}

Pyrolysis is one of the most studied processes for biomass upgrading since it only requires heating the raw material to produce both, fuels and useful chemicals (gases, liquid and a carbon residue, the char). The heating is traditionally performed by a gaseous stream (inert or not) at elevated temperature that is continuously put in contact with biomass, increasing its temperature and breaking the bonds between and inside biomass components. There are several operational variables in pyrolysis like the solid and gas residence time, the temperature range, the heating rate, the final temperature, the sample size and the atmosphere type. The latter can be inert or oxidant to perform a real pyrolysis or an oxidative gasification process, respectively. Depending on their relative values, pyrolysis can be classified in three different types (slow, fast and flash) where the yield distribution is different (Jahirul et al., 2012; Ranzi et al., 2008) . Moreover, biomass type and pre-treatments also affect this yield distribution and the product quality, respectively. For instance, up to $20 \%$ higher liquid yields are obtained with softwood than with hardwood samples (Das \& Sarmah, 2015; Kan et al., 2016; Oudenhoven et al., 2016; Ru et al., 2015). Regarding the reaction pathway for pyrolysis in an inert atmosphere, the most extended version is the Waterloo's mechanism (Elyounssi et al., 2012; Shafizadeh, 1982; Van de Velden et al., 2010). It establishes three distinct types of reactions for cellulose degradation: dehydration $\left(<300{ }^{\circ} \mathrm{C}\right.$ and slow heating rate), depolymerization (from $300{ }^{\circ} \mathrm{C}$ to $450{ }^{\circ} \mathrm{C}$ ) and fragmentation (around $600{ }^{\circ} \mathrm{C}$ ). Moreover, it also considers secondary reactions, cracking and water-gas shift reactions. This mechanism can be also applied for biomass, following again two types of reactions: primary and secondary reactions. The formers are the breaking of biomass into char, tar (liquid product) and gases and the secondary are the degradation of the produced liquid in char, other tar and gases. For oxidative pyrolysis, the mechanism is the same but oxidation reactions are present too, enhancing the degradation. In addition, slow pyrolysis is the process present in a thermogravimetric analysis (TGA). It basically consists of an analytical balance where the sample is introduced and then a hot stream of gas is fed, gasifying the sample 


\section{Chapter 3}

and recording the mass variation (plotting versus time or temperature constitutes the thermogram). This technique only requires a little amount of material (between 5 and 10 $\mathrm{mg}$ ) and it is an uncomplicated way for both, biomass characterization and biomass pyrolysis study. For this reason, many works about this technique and its physicochemical modelling can be found in literature (Biney et al., 2015; Cabeza et al., 2015; Capart et al., 2004; Chen et al., 2011; Cheng et al., 2012; Daouk et al., 2015; Hu et al., 2016; Kastanaki et al., 2002; Lv et al., 2010; Mangut et al., 2006; Ogawa et al., 2014; Scott et al., 2006; Seo et al., 2010; Serapiglia et al., 2009; Serapiglia et al., 2008; Sharma et al., 2014; Slopiecka et al., 2012; Völker \& Rieckmann, 2002; Williams \& Besler, 1996). Concerning the modelling, the most extended option is a first order decomposition kinetics, assuming that hemicellulose, cellulose and lignin degradations are independent. However, when a deeper analysis is required, this kinetics is not good enough and, for this reason, there are many other better and complex options, like $\mathrm{n}^{\text {th }}$ order, diffusional or nucleation kinetics. A good review of all of them can be found in the work of Mian Hu et al. (Hu et al., 2016). Additionally, in this work, a non-conventional model for biomass thermal degradation is also presented. It is based on a Frazer-Suzuki deconvolution and it reproduces very well the experimental results (deviations lower than $2.0 \%$ ). However, it requires 5 parameters per simulated compound and their physical meaning is not totally clear. Moreover, they also use a free activation energy model to reproduce the biomass thermal decomposition. It also generates adequate results (deviations lower than $5.2 \%$ ) but again, the physical meaning of the parameters (4 per compound) is not clear. Other interesting model can be found in Dong Kyun Seo et al. (Seo et al., 2010), where a direct and useful expression, which considers the heating rate, to estimate the kinetics of biomass thermal breaking and for the gaseous and liquid production is conducted. However, their modelling considers biomass without considering the different biopolymers. Therefore, the simulation of them may not be physically consistent. Similarly to this last work, Paul O. Biney et al. (Biney et al., 2015) also successfully developed a model as a function of the heating rate but, in this case, applying it to all the pseudo-compounds that can be present in biomass (characterized by the maximum or minimum observed in a differential thermogravimetric analysis). Other interesting study is the performed by Kun Cheng et al. (Cheng et al., 2012) where they estimated the kinetic parameters (activation energy and pre-exponential factor) for pure hemicellulose, cellulose, lignin and a complex sample (maple) by high-Resolution Modulated TGA and 
without any mathematical model. It is remarkable that their calculated activation energies agree with the obtained by a distributed activation energy model and their conclusion on composition estimation by a thermogravimetric analysis: it is more precisely when oxidant atmosphere is used. A conclusion that agrees with the work of Michelle J. Serapiglia et al. (Serapiglia et al., 2009) about biomass composition estimation by high resolution thermogravimetric analysis. Moreover, works dealing with a continuous processing of biomass in a thermal degradation reactor can be already found (Jae et al., 2014; Ranzi et al., 2014). Unfortunately, all these works mainly focus on conventional lignocellulosic samples or lignin-free samples. Therefore, information about the thermal degradation of other biomasses, including the effect of a pretreatment, is barely available. For this reason, the thermal degradation of solid samples of Brazilian ginseng (Pfaffia glomerata) roots are analyzed before and after being subjected to solid-fluid pretreatments in this work. This assessment includes thermograms, X-ray Powder Diffraction (DRX) and Differential Scanning Calorimetry (DSC). Additionally, the thermogram is fitted by a model devolved in a previous work (Cabeza et al., 2015) and with a modified version of the Waterloo mechanism for slow pyrolysis to analyze how these pretreatments modifies its thermal degradation behavior. This mechanism assumes that any biopolymer in biomass decomposes into char and gasses and that the char formed also breaks into volatiles (Figure 1). The model follows an autocatalytic or nucleation kinetics, since it has been demonstrated that it can reproduce biomass breaking with a few parameters of easy understanding physical meaning. Ginseng was selected as a case study biomass since it is a good example of a non-conventional biomass (it is a freehemicellulose biomass) and it has been demonstrated as a sustainable source of target compounds, like beta-ecdysone (Vardanega et al.).

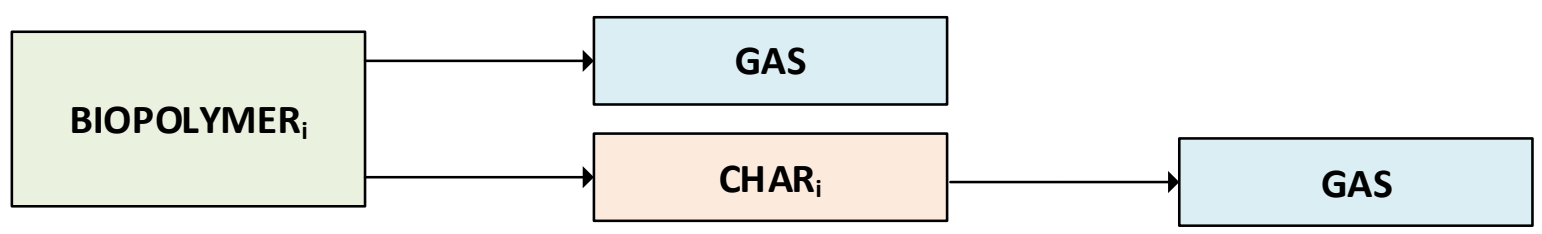

Figure 1. Biomass thermal cleaving reaction pathway for slow pyrolysis (Cabeza et al., 2015). Note: sub-index "i” corresponds to the specific biopolymer (HC, C or L). 


\section{Chapter 3}

\section{Materials and Methods}

The experimental conditions and sample composition are arrayed in Table 1. Additionally, a brief description of the equipment used to obtain all the data is done below.

Table 1. Experiments data: sample, composition and atmosphere.

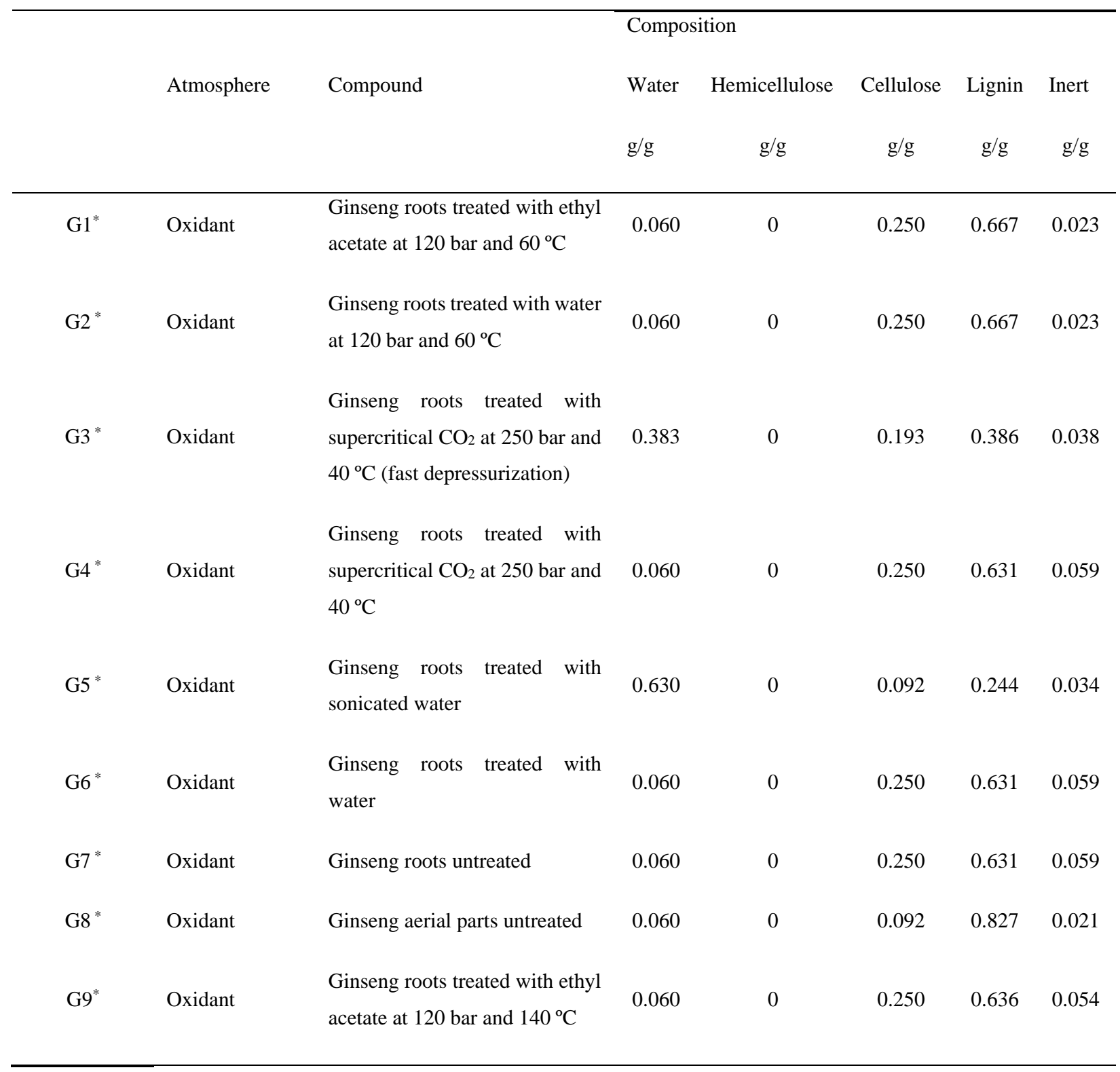

* Composition estimated from the TGA 


\section{Chapter 3}

Data for oxidant degradation of Brazilian ginseng (Pfaffia glomerata) roots was experimentally determined at Campinas, Brazil. Brazilian ginseng roots (Pffafia glomerata) were cultivated in the experimental field of CPQBA (Campinas, Brazil), where they were collected being 7 years old. They were washed and dried in a forced air circulation dryer at $140{ }^{\circ} \mathrm{C}$ for 5 days. The dried roots were then comminuted in a pulse mill (Marconi, model MA 340, Piracicaba, Brazil) for few seconds. Then, the particles of higher size were again milled by a knife mill (Tecnal, model TE 631, Piracicaba, Brazil) for $2 \mathrm{~s}$ at 18,000 rpm and finally, they were separated according to their size using sieves (Series Tyler, W.S. Tyler, Wheeling, IL). The milled roots were stored in a freezer (Metalfrio, model DA 420, São Paulo, Brazil) at $-10^{\circ} \mathrm{C}$. For the pretreatment assays, particles of $7.89 \mu \mathrm{m}$ of diameter were used and they were performed at University of Campinas, Brazil. All these assays were aimed at verifying the effect of the fluid and/or condition (pressure, temperature, ultrasound sonication) on Brazilian ginseng. Thus, the biomass was analyzed before and after being subjected to both processes by TGA, DSC and XRD. In addition, untreated Brazilian ginseng (Pfaffia glomerata) aerial parts were also analyzed for comparison purposes. In this case the thermogravimetric analyses were performed in a thermogravimetric analyzer TGA-50, Shimadzu, Tokyo, Japan, between $24{ }^{\circ} \mathrm{C}$ and $603{ }^{\circ} \mathrm{C}$ at a heating rate of $10{ }^{\circ} \mathrm{C} / \mathrm{min}$ with a synthetic air atmosphere $(20$ \% oxygen).. For DSC analysis a Shimadzu Differential Scanning Calorimeter DSC-50, Shimadzu, Tokyo, Japan was used with a heating rate of $10{ }^{\circ} \mathrm{C} / \mathrm{min}$ and a temperature range between $30^{\circ} \mathrm{C}$ and $500{ }^{\circ} \mathrm{C}$. Finally, the X-ray diffraction studies were done by a D5000 Siemens Difractor (D5000, Siemens, Amsterdam, Holland) with a $\mathrm{Cu}-\mathrm{K}$ as a radiation source and a voltage of $40 \mathrm{kV}$ and $30 \mathrm{~mA}$; the scan was performed with steps $0.01^{\circ}$ in size, the time per step equal to $5 \mathrm{~s}$ and a range of reflection of $10^{\circ}-60^{\circ}$. All these experiments were performed twice and the deviation was lower than $5 \%$.

\section{Results and discussion}

\subsection{Kinetic model}

Our research group at the University of Valladolid (hpp.uva.es), Spain, previously developed the model used in this work. It was obtained applying a transient mass balance for each compound in the sample (Eq. ( 1 )) and taking into account the following 


\section{Chapter 3}

assumptions: (1) all the reactions are irreversible and independent, (2) the whole sample is at the same temperature and (3) there is not diffusional mass transport for liquids.

$$
\frac{d m_{j}}{d t}=r_{j}=\sum_{i=1}^{N_{r}} g_{i j} \cdot r_{i}
$$

Regarding kinetics, two different types were used: one for liquid phase and another for the solid. For the liquid, it was developed by a conventional mass transfer expression that was modified to consider the effect of the sample mass reduction (Eq. ( 2 )). In this equation, $C_{j}^{*}$ is the equilibrium concentration in the gas phase, which was calculated by the assumption of ideal gas behavior and using a modified Antoine's pressure vapor expression. This liquid phase refers to the water and the oil that can be present in the biomass sample.

$$
r_{i}=h \cdot\left(C_{j}^{*}\right) \cdot m_{j}^{n l_{i}}
$$

For the solid, a first order autocatalytic expression was considered since it was demonstrated that it is useful to reproduce abrupt changes (Eq. ( 3 )) (Cabeza et al., 2015; Capart et al., 2004). The parameter $\alpha_{i}$ is known as the initial velocity factor, which gives an idea about how difficult is to degrade the sample, and it was fixed at 0.99 . $\beta_{i}$ is the acceleration factor and it represents how fast degradation is once it has started. This equation was modified for cellulose with another parameter (c) to consider the effect of the heating rate in thermal degradation (Eq. ( 4 )). In this work, the value for parameter "c" was taken from the previous study (Cabeza et al., 2015). So, it was fixed at 0.0001 since it was the value for pure cellulose, the only feasible previous case with no hemicellulose.

$$
\begin{gathered}
r_{i}=k_{i} \cdot e^{-\frac{E a_{i}}{R \cdot T}} \cdot \mathrm{m}_{\mathrm{j}} \cdot\left(1-\alpha_{i} \cdot m_{j}\right)^{\beta_{i}} \\
r_{i}=k_{\mathrm{i}} \cdot e^{-\frac{E_{a_{i}}}{R \cdot T}+c \cdot T+\ln (T)} \cdot \mathrm{m}_{\mathrm{j}} \cdot\left(1-\alpha_{i} \cdot m_{j}\right)^{\beta_{i}}
\end{gathered}
$$

Finally, this model was used to adjust the experiments showed in Table 1. This fitting implies an optimization problem that was solved by two mathematical methods: the Simplex Nelder-Mead's method to obtain an initial estimation of the parameters and the 


\section{Chapter 3}

Broyden-Fletcher-Goldfarb-Shanno's method to improve this initial solution. The system of ordinary differential equations (ODEs) was solved by the Runge-Kutta's method with $8^{\text {th }}$ order of convergence (Press et al., 2007). The objective function selected was the Absolute Average Deviation (AAD) defined in Eq. ( 5 ). All parameters obtained are arrayed in Table 2. The software used for the optimization is free available at http://hpp.uva.es/software/.

$$
A A D=\sum_{i=1}^{N} \frac{1}{N} \cdot \frac{\left|x_{i_{E X P}}-x_{i_{S I M}}\right|}{x_{i_{E X P}}}
$$

\subsection{Thermograms fitting}

In this section, the 9 different samples of Brazilian ginseng (Pfaffia glomerata) were adjusted with the proposed model, also providing a coherent simulation for the individual compounds (it can be seen for the ginseng roots treated with ethyl acetate at 120 bar and $60{ }^{\circ} \mathrm{C}$ or case G1 in Figure 2. a). Regarding the obtained parameters, it is worth highlighting that the mass transfer coefficient for the ginseng roots extracted with supercritical $\mathrm{CO}_{2}$ at 250 bar and $40{ }^{\circ} \mathrm{C}$ and a fast depressurization (G3) and those roots treated with sonicated water or case G5 (Table 2-b) was different from the average value used in all the other cases. This discrepancy was obtained because these two samples had a high-water content. Therefore, diffusional effects were present during water vaporization, reducing the mass transfer.

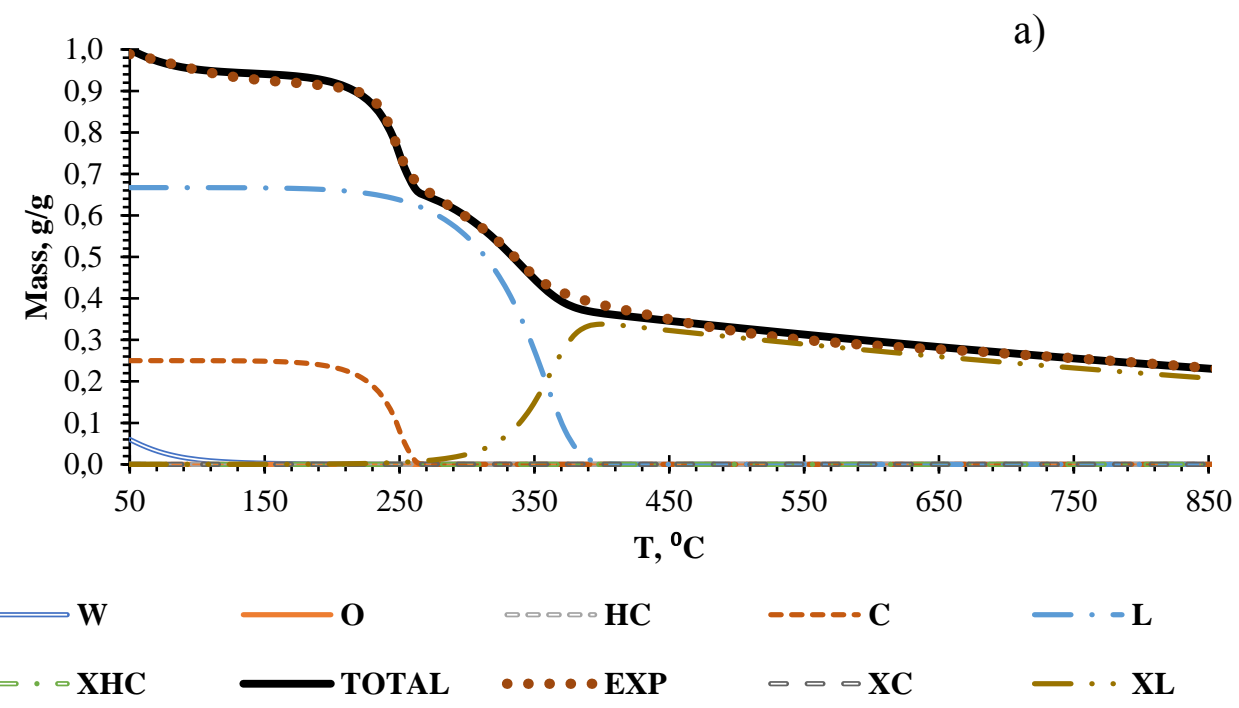




\section{Chapter 3}

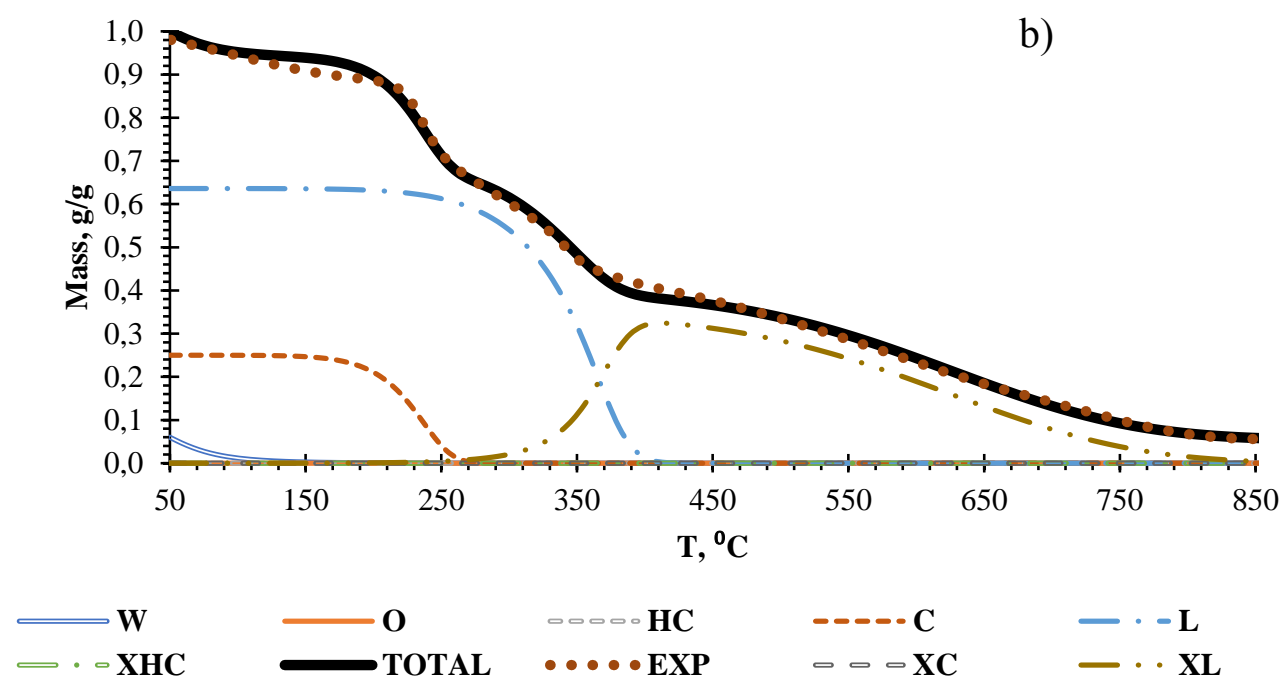

Figure 2. Ginseng roots treated with ethyl acetate at $120 \mathrm{bar}-60^{\circ} \mathrm{C}(\mathrm{a})$ and $140{ }^{\circ} \mathrm{C}$ (b) thermogram. W: water mass fraction, $\mathrm{O}$ : oil mass fraction, $\mathrm{HC}$ : hemicellulose mass fraction $\mathrm{C}$ : cellulose mass fraction, $\mathrm{L}$ : lignin mass fraction, XHC: hemicellulose char mass fraction, XC: cellulose char mass fraction, XL: lignin char mass fraction and TOTAL: simulated behavior. 
Table 2. Kinetics (a), mass transfer parameters (b) and AAD (c) obtained from the adjustment.

\begin{tabular}{|c|c|c|c|c|c|c|c|c|c|c|c|c|c|c|c|c|c|c|c|c|c|c|c|c|c|c|c|}
\hline & $\mathrm{k}_{1}$ & $\mathrm{k}_{2}$ & $\mathrm{k}_{3}$ & $\mathrm{k}_{4}$ & $\mathrm{k}_{5}$ & $\mathrm{k}_{6}$ & $\mathrm{k}_{7}$ & $\mathrm{k}_{8}$ & k9 & $\overline{\mathrm{Ea}_{1} / \mathrm{R}}$ & $\overline{\mathrm{Ea}_{2} / \mathrm{R}}$ & $\overline{\mathrm{Ea}_{3} / \mathrm{R}}$ & $\overline{\mathrm{Ea} / / \mathrm{R}}$ & $\overline{\mathrm{Ea}_{5} / \mathrm{R}}$ & $\overline{\mathrm{Ea}_{6} / \mathrm{R}}$ & $\overline{\mathrm{Ea} / / \mathrm{R}}$ & $\overline{\mathrm{Ea} / \mathrm{R}}$ & $\overline{\mathrm{Ea} / \mathrm{R}}$ & $\beta_{1}$ & $\beta_{2}$ & $\beta_{3}$ & $\beta_{4}$ & $\beta_{5}$ & $\beta_{6}$ & $\beta_{7}$ & $\beta_{8}$ & $\beta_{9}$ \\
\hline a) & $\min ^{-1}$ & $\min ^{-1}$ & $\min ^{-1}$ & $\min ^{-1}$ & $\min ^{-1}$ & $\min ^{-1}$ & $\min ^{-1}$ & $\min ^{-1}$ & $\min ^{-1}$ & K & K & K & K & K & K & K & K & $\mathrm{K}$ & - & - & - & - & - & - & - & - & - \\
\hline$\overline{\mathrm{G} 1}$ & 0 & 45,293 & 32,073 & 45,042 & 0.025 & 43,903 & 0 & 0.069 & 0 & 6,922 & 8,101 & 7,399 & 6,562 & 101 & 9,061 & 5,830 & 103 & 100 & 0.008 & 10.0 & 0 & 3.5 & 0 & 0.424 & 0.764 & 3.982 & 0.511 \\
\hline G2 & 0 & 45,303 & 32,035 & 45,002 & 0.018 & 43,903 & 0 & 0.069 & 0 & 6,922 & 8,004 & 7,532 & 6,832 & 115 & 9,061 & 5,830 & 103 & 100 & 0.008 & 10.0 & 0 & 3.5 & 0.012 & 0.424 & 0.764 & 3.982 & 0.511 \\
\hline G3 & 0 & 46,788 & 41,767 & 50,000 & 634 & 43,577 & 0 & 0.07 & 0 & 6,922 & 8,481 & 7,494 & 6,927 & 6047 & 11,938 & 5,830 & 103 & 100 & 0.008 & 7.0 & 0 & 3.5 & 3.835 & 0.424 & 0.764 & 3.982 & 0.511 \\
\hline G4 & 0 & 46,788 & 41,762 & 50,000 & 772 & 43,577 & 0 & 0.07 & 0 & 6,922 & 8,481 & 7,478 & 6,632 & 5928 & 11,938 & 5,830 & 103 & 100 & 0.008 & 7.0 & 0 & 3.47 & 3.805 & 0.424 & 0.764 & 3.982 & 0.511 \\
\hline G5 & 0 & 45,476 & 41,767 & 50,000 & 634 & 43,569 & 0 & 0.072 & 0 & 6,922 & 9,167 & 7,494 & 6,927 & 6047 & 12,004 & 5,830 & 103 & 100 & 0.008 & 0.0 & 0 & 3.5 & 3.835 & 0.424 & 0.764 & 3.982 & 0.511 \\
\hline G6 & 0 & 46,707 & 41,533 & 49,995 & 1,041 & 43,731 & 0 & 0.073 & 0 & 6,922 & 9,534 & 7,602 & 6,602 & 5820 & 11,985 & 5,830 & 104 & 100 & 0.008 & 2.0 & 0 & 3.47 & 3.805 & 0.424 & 0.764 & 3.982 & 0.511 \\
\hline G7 & 0 & 46,783 & 41,691 & 49,737 & 422 & 43,543 & 0 & 0.069 & 0 & 6,922 & 8,479 & 7,540 & 6,797 & 5944 & 11,974 & 5,830 & 103 & 100 & 0.008 & 7.0 & 0 & 3.47 & 3.805 & 0.424 & 0.764 & 3.982 & 0.511 \\
\hline G8 & 0 & 46,701 & 41,569 & 49,977 & 848 & 43,731 & 0 & 0.073 & 0 & 6,922 & 8,579 & 7,317 & 6,526 & 5911 & 11,985 & 5,830 & 104 & 100 & 0.008 & 2.0 & 0 & 3.47 & 3.805 & 0.424 & 0.764 & 3.982 & 0.511 \\
\hline G9 & 0 & 46,487 & 35,845 & 49,737 & 115 & 43,544 & 0 & 0.069 & 0 & 6,922 & 8,602 & 7,559 & 6,797 & 5991 & 11,985 & 5,830 & 104 & 100 & 0.008 & 2,5 & 0 & 3.47 & 0.001 & 0.424 & 0.764 & 3.982 & 0.511 \\
\hline
\end{tabular}

Note: the constant sub-index corresponds to reaction number; 1: hemicellulose gasification, 2: cellulose gasification, 3: lignin gasification, 4: lignin char production, 5: lignin char gasification, 6: cellulose char production, 7: hemicellulose char production, 8: cellulose char gasification and 9: hemicellulose char gasification

\begin{tabular}{ccc}
\hline & $\mathrm{h}$ & $\mathrm{nli}$ \\
$\mathrm{b})$ & $\mathrm{g} \cdot \mathrm{m} \cdot \mathrm{min}^{-1} \cdot \mathrm{mol}^{-1}$ & - \\
\hline Others $^{1}$ & 3,000 & 2.00 \\
G3 & 528 & 2.00 \\
G5 & 88 & 1.77 \\
\hline
\end{tabular}

\begin{tabular}{cc}
\hline c) & ADD \\
\hline G1 & 1.73 \\
G2 & 2.10 \\
G3 & 2.80 \\
G4 & 2.46 \\
G5 & 4.90 \\
G6 & 5.56 \\
G7 & 6.18 \\
G8 & 9.30 \\
G9 & 2.98 \\
\hline AVERAGE & 4.22 \\
\hline
\end{tabular}




\section{Chapter 3}

\subsection{Pretreatment effect}

\subsubsection{Pressurized liquids at 120 bar}

It can be noticed in Figure 2 that a pressurized liquid treatment had a direct effect on the ginseng roots pyrolysis. If the pretreatment was done at low temperature $\left(60^{\circ} \mathrm{C}\right)$, using water (G1) or ethyl-acetate $(\mathrm{G} 2)$, the produced charcoal was extremely difficult to gasify, even in an oxidant atmosphere, independently of the type of liquid used (water or ethyl acetate). In contrast, if temperature was raised up to $140{ }^{\circ} \mathrm{C}$ (G9) a more conventional behavior was obtained since all the produced charcoal was depleted (Figure 2-b). In order to shed light on this pretreatment temperature effect, a comprehensive analysis of the changes in thermal degradation kinetics was done (Figure 3).
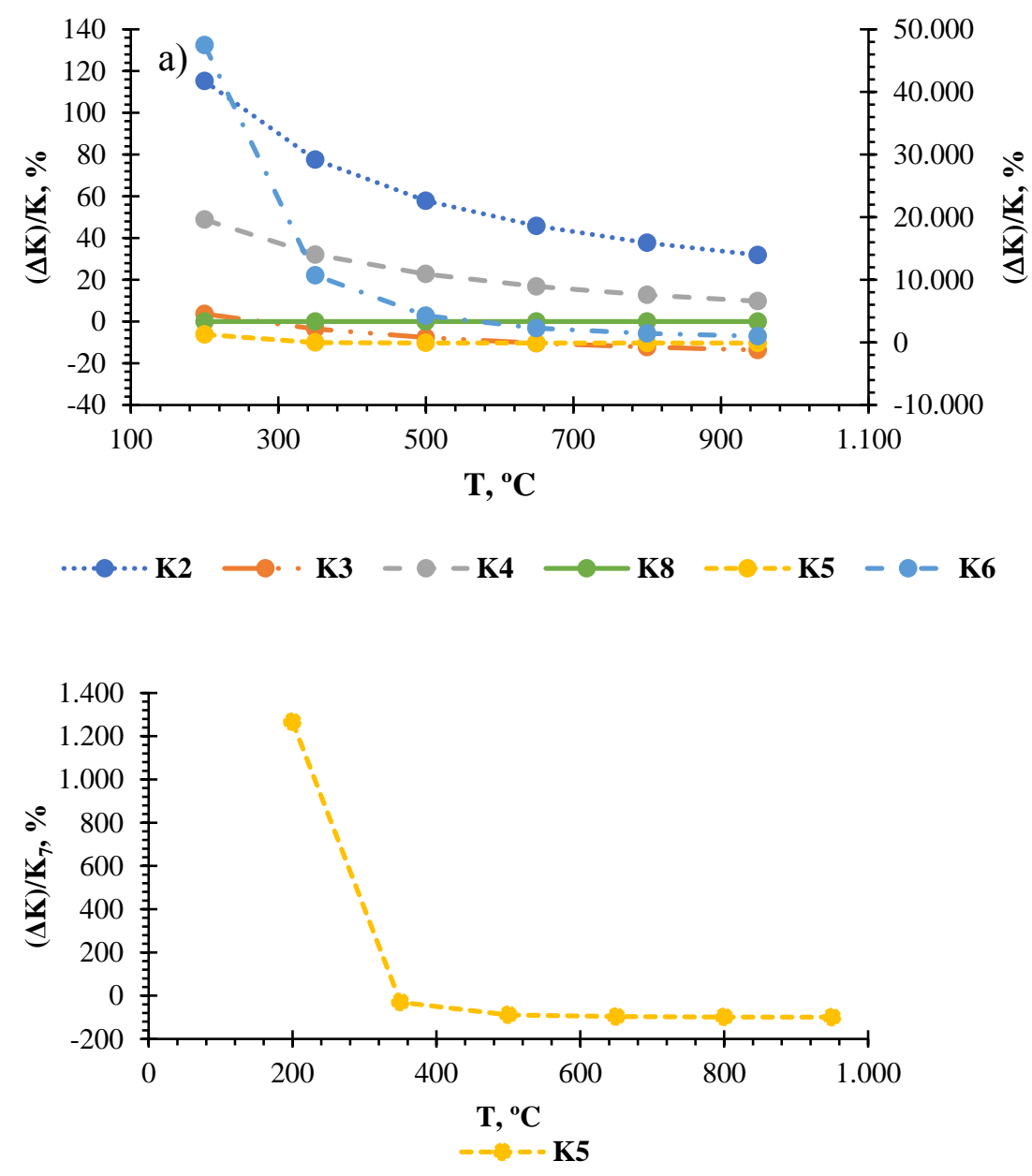


\section{Chapter 3}
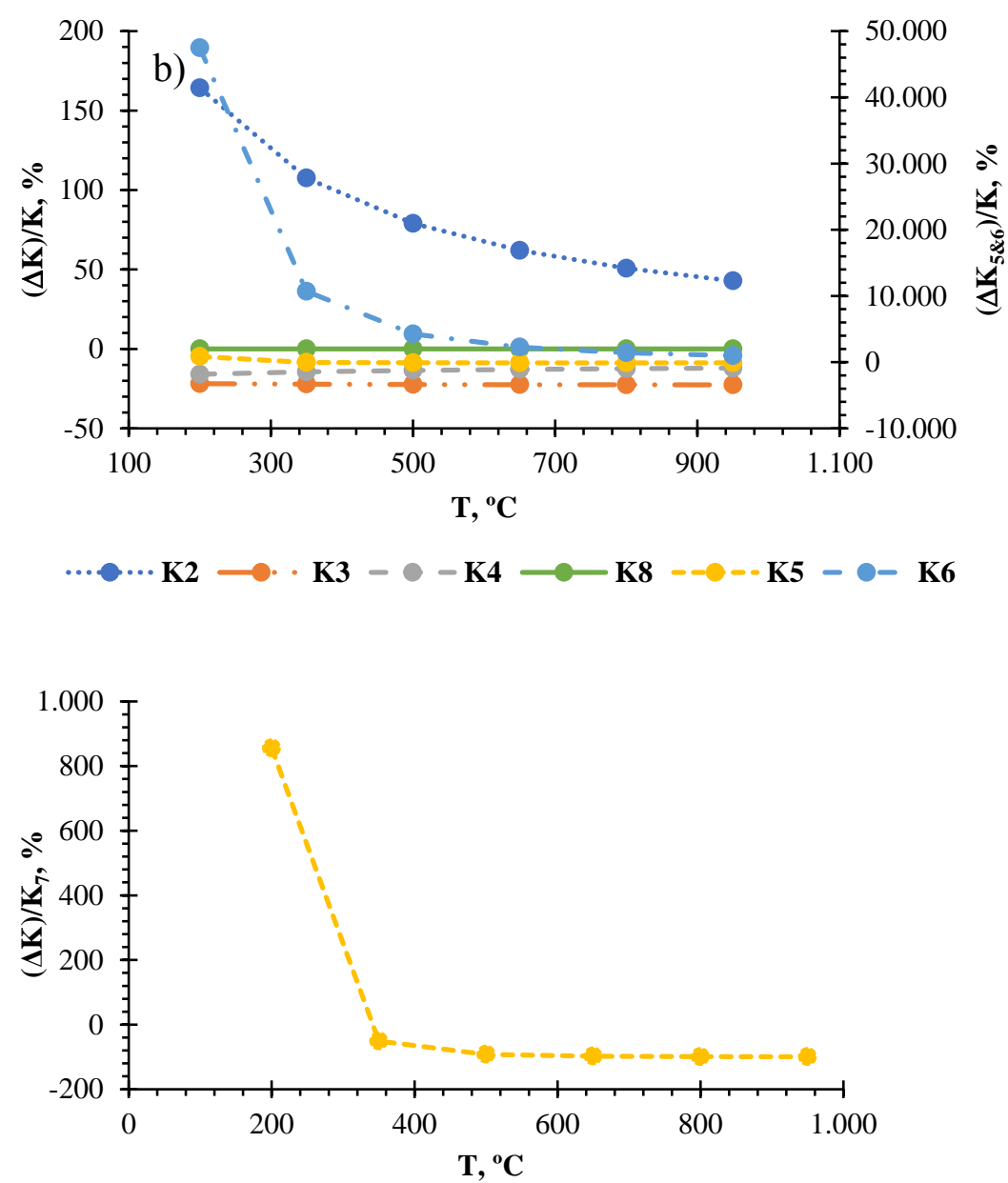

$--1 \mathrm{~K} 5$
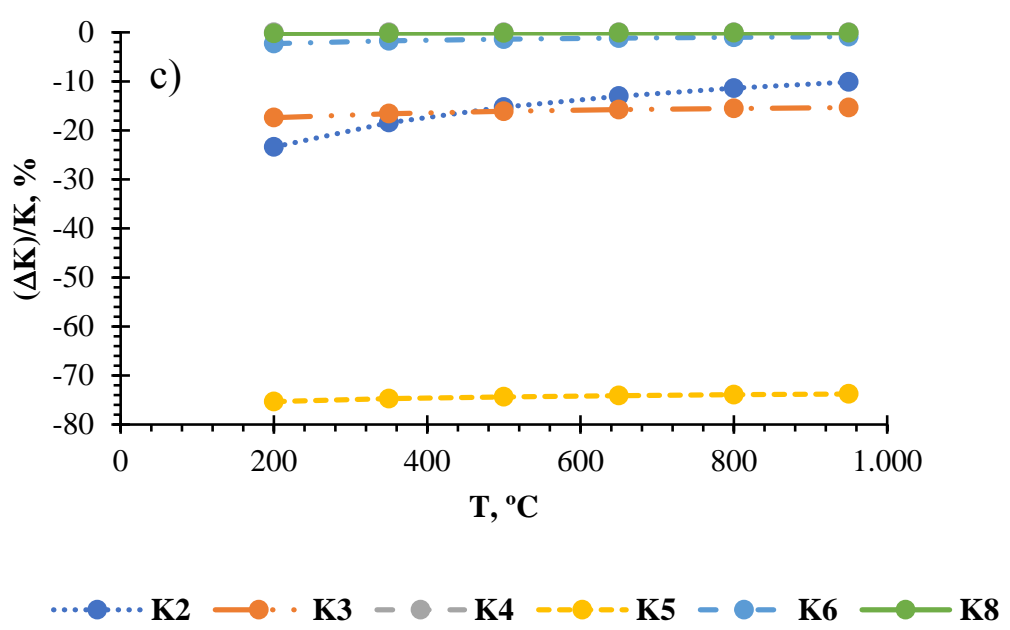

Figure 3. Kinetic change when sample G7 is treated by pressurized ethyl acetate at $60^{\circ} \mathrm{C}(\mathrm{a})$, water at $60^{\circ} \mathrm{C}(\mathrm{b})$ and ethyl acetate at $140{ }^{\circ} \mathrm{C}(\mathrm{c}) . \mathrm{K}_{2}$ : cellulose gasification, $\mathrm{K}_{3}$ : lignin gasification, $\mathrm{K}_{4}$ : lignin char formation, $\mathrm{K}_{5}$ : lignin char gasification, $\mathrm{K}_{6}$ : cellulose char formation and $\mathrm{K}_{8}$ : cellulose char gasification. 
Figure 3-a shows the kinetic differences between the sample G1 and the untreated sample $\mathrm{G} 7\left(\left(\mathrm{~K}_{\mathrm{iGj}}-\mathrm{K}_{\mathrm{iG}}\right) / \mathrm{K}_{\mathrm{iG} 7} \cdot 100\right)$ at several thermal degradation temperatures. It can be observed that, while the cellulose gasification $\left(\mathrm{K}_{2}\right)$ was highly promoted by the pretreatment, lignin volatilization $\left(\mathrm{K}_{3}\right)$ was slightly worsen. Regarding the formation of char from cellulose and lignin ( $\mathrm{K}_{6}$ and $\mathrm{K}_{4}$, respectively), both were promoted by the pretreatment. Finally, char degradation for cellulose $\left(\mathrm{K}_{8}\right)$ was unaffected and for lignin $\left(\mathrm{K}_{5}\right)$ it was extremely reduced. Cellulose results can be explained by the fact that its structure would be modified during the pretreatment, swelling and making it easier to gasify it and to produce char, being the former the predominant process. Char gasification would not be affected because the cellulose oligomers would not change (low temperatures and it is insoluble in ethyl acetate), obtaining a similar cellulose char to the produced in untreated roots (G7). In relation to lignin, its gasification would be reduced because it is partially soluble in ethyl acetate, removing the weakest fractions and promoting its char production, which would be more difficult to gasify due to changes related to this lignin extraction. Moreover, lignin was not totally affected due to the mild operational conditions, which reveals why its kinetic changes are lower. The low temperature water treatment (Figure 3-b) presented the same behavior for cellulose, being the swelling again the cause, but for lignin some differences were obtained. In this case, the pretreatment reduced all lignin kinetics but gasification was far more affected than char formation and char volatilization. However, its kinetic change was lower in this case due to the fact that lignin is not soluble in water. This kinetic reduction in lignin can be originated by the fact that cellulose would be the main fraction affected by water, solving isolated sugars and swelling it. Therefore, cellulose would be much easier to degrade than in the untreated case G7, behaving as a shield for lignin. Concerning the case where ethyl acetate at $140{ }^{\circ} \mathrm{C}$ was used (G9, Figure $3-c)$, cellulose and lignin gasification and lignin char volatilization decayed and all the other kinetic were not affected, which can be due to a more effective extraction because of the higher operational temperature. Therefore, all the weakest part of the sample would have been removed, leaving a more porous exhausted solid that would be more difficult to gasify ( $\mathrm{K}_{2}$ and $\mathrm{K}_{3}$ lower). Nevertheless, its produced char would be so porous that is volatilization would be easier than in samples at $60{ }^{\circ} \mathrm{C}(\mathrm{G} 1$ and $\mathrm{G} 2)$, which agrees with the results reported by (Silva Filho \& Milioli, 2008). Furthermore, it is worth highlighting that in the three cases the reduction in lignin volatilization $\left(\mathrm{K}_{3}\right)$ can be also due to a removal of the extractives present in the sample. As a result, it can be concluded that the 


\section{Chapter 3}

strongest char is only produced when the pretreatment was able to modify cellulose behavior due to a structural change (swelling) but only if extraction was low enough to ensure that the exhausted solid porosity was not excessively high. A conclusion supported by the fact that the same strong charcoal may be observed in untreated samples when the lignin content is higher (Parascanu et al., 2017). Moreover, it can be also checked in literature that water liquid treatments partially carbonize the sample, although it was not expected in this study due to the mild conditions used during the treatment (Carpenter et al., 2014).

On the other hand, the differences observed in the kinetics between low and high thermal degradation temperatures in the cases low temperatures cases can be associated to the mild operational conditions during the pretreatment too. Additionally, the pretreatment effect would had a lower impact at higher pyrolysis temperatures because of the exponential temperature dependence.

\subsubsection{Supercritical CO2}

It can be seen In Figure 4 that a pre-treatment with supercritical $\mathrm{CO}_{2}$, with fast depressurization $(\mathrm{G} 3)$ or not $(\mathrm{G} 4)$, drove to a very small reduction in cellulose gasification $\left(\mathrm{K}_{2}\right)$ and an increment in lignin and lignin char gasification $\left(\mathrm{K}_{3}\right.$ and $\left.\mathrm{K}_{6}\right)$. In addition, cellulose char formation and its gasification $\left(\mathrm{K}_{6}\right.$ and $\left.\mathrm{K}_{8}\right)$ were also increased, even though just a little. This behavior would be obtained because $\mathrm{CO}_{2}$ only should extract the nonpolar compounds that were present in the natural matrix, degrading the lignin structure due to its high diffusivity and explaining why it was the most affected compound in this case. The role of the depressurization can be observed in lignin char production $\left(\mathrm{K}_{4}\right)$, being reduced only when a fast depressurization took place. Which is an expected behavior because a quick change in pressure means a breaking of the sample structure, promoting its gasification. 

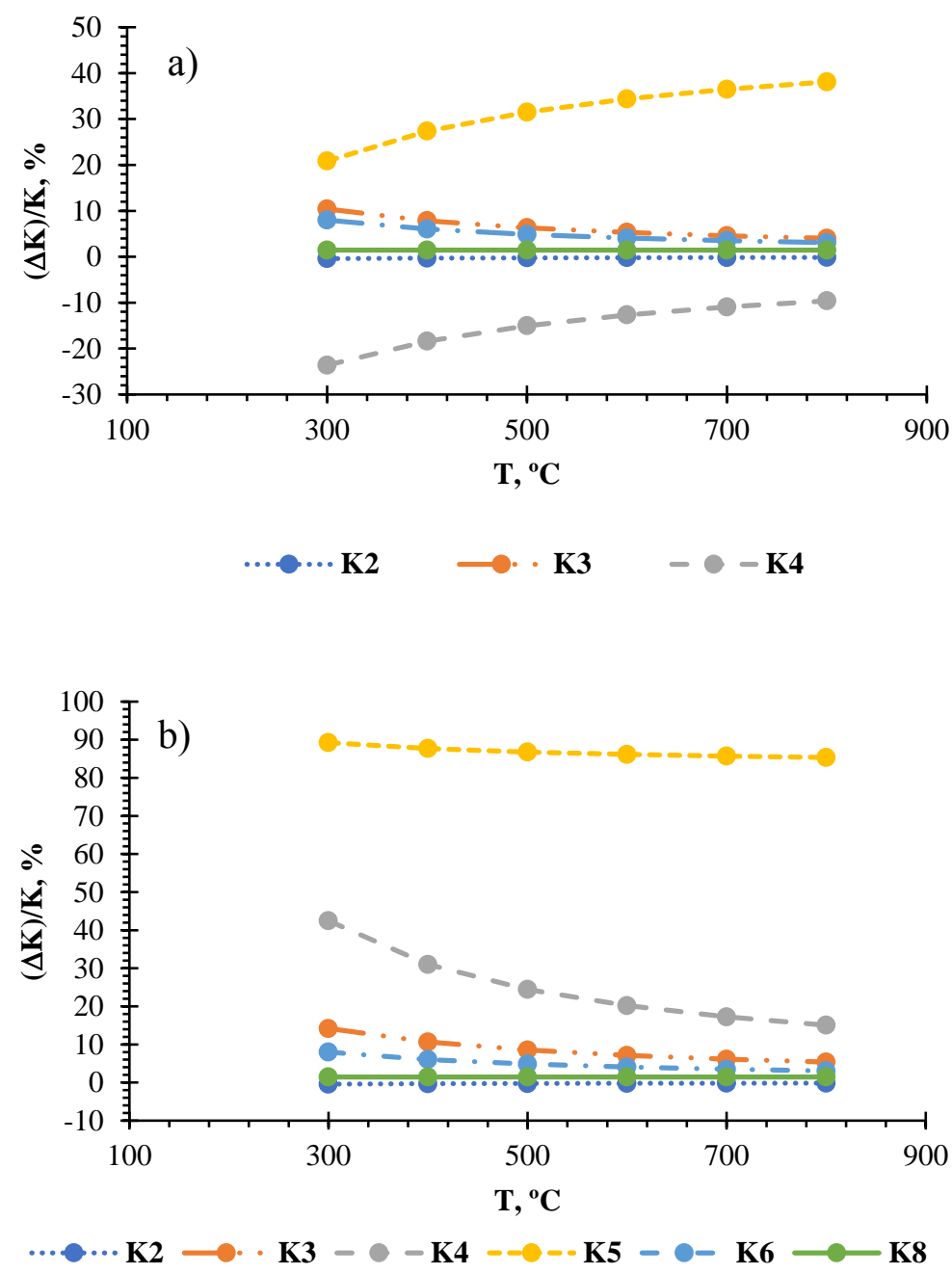

Figure 4. Kinetic change when sample $\mathrm{G} 7$ is treated by pressurized supercritical $\mathrm{CO}_{2}$ - fast depressurization and by pressurized supercritical $\mathrm{CO}_{2}$ (b). $\mathrm{K}_{2}$ : cellulose gasification, $\mathrm{K}_{3}$ : lignin gasification, $\mathrm{K}_{4}$ : lignin char formation, $\mathrm{K}_{5}$ : lignin char gasification, $\mathrm{K}_{6}$ : cellulose char formation and $\mathrm{K}_{8}$ : cellulose char gasification.

\subsubsection{Ambient pressure water}

In this case, a water treatment (Figure 5-b) only should extract a very little amount of soluble compounds (mainly free sugars and the amorphous fraction of cellulose (Cabeza et al., 2016)), which would imply a more difficult degradation of cellulose $\left(\mathrm{K}_{2}\right)$, making it more difficult to aerate. Additionally, water soluble compounds present (extractives) in the lignin matrix could be removed, explaining why its gasification is lower too $\left(\mathrm{K}_{3}\right)$. Therefore, char production would be improved $\left(\mathrm{K}_{4}\right.$ and $\left.\mathrm{K}_{6}\right)$, as it was obtained. However, a strong char was not obtained since the low pressure, being water not able to really modify the internal structure due to a lower diffusivity. Ultrasound implied a change in 


\section{Chapter 3}

lignin behavior (Figure 5-a), promoting its gasification and reducing its transformation into char. This phenomenon took places because ultrasound would mainly affect lignin since it is a 3D structure around cellulose. A structure that would break, enhancing its volatilization against char formation.
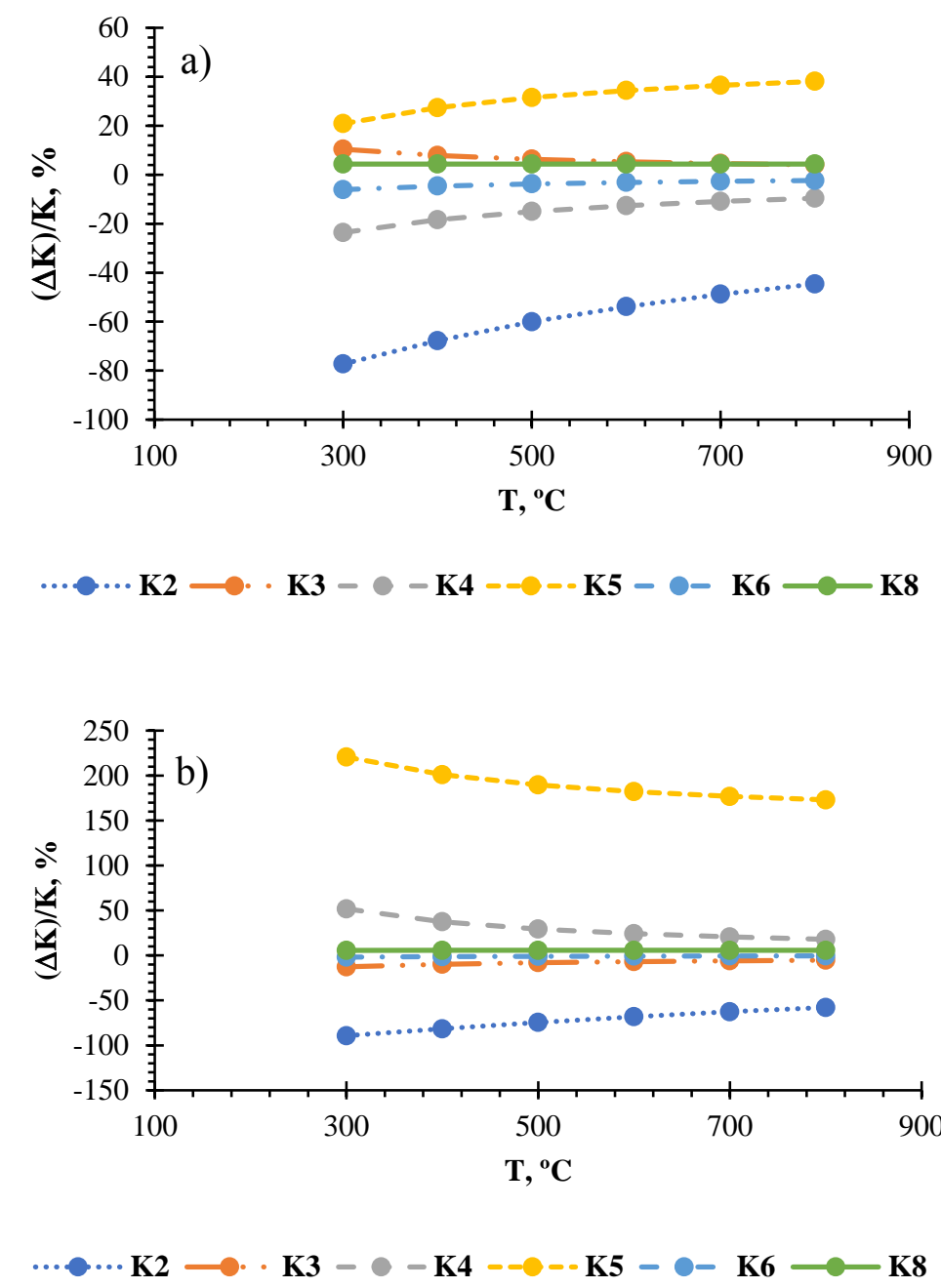

Figure 5. Kinetic change when sample G7 is treated by sonicated water (a) and water (b) at ambient pressure. $\mathrm{K}_{2}$ : cellulose gasification, $\mathrm{K}_{3}$ : lignin gasification, $\mathrm{K}_{4}$ : lignin char formation, $\mathrm{K}_{5}$ : lignin char gasification, $\mathrm{K}_{6}$ : cellulose char formation and $\mathrm{K}_{8}$ : cellulose char gasification.

\subsubsection{Aerial parts}

Finally, the differences between two parts of ginseng (G7 and G8, roots and aerial part respectively) are analyzed in this subsection. It can be checked in Figure 6 that sample G8 implied a lower gasification for cellulose and its char production ( $\mathrm{K}_{2}$ and $\left.\mathrm{K}_{6}\right)$ while char gasification was a bit promoted $\left(\mathrm{K}_{8}\right)$. Regarding lignin, all its kinetics were enhanced. Therefore, it is interesting to confirm once more that, although both samples 


\section{Chapter 3}

come from the same biomass, their behavior is completely different due to some differences in their structure.

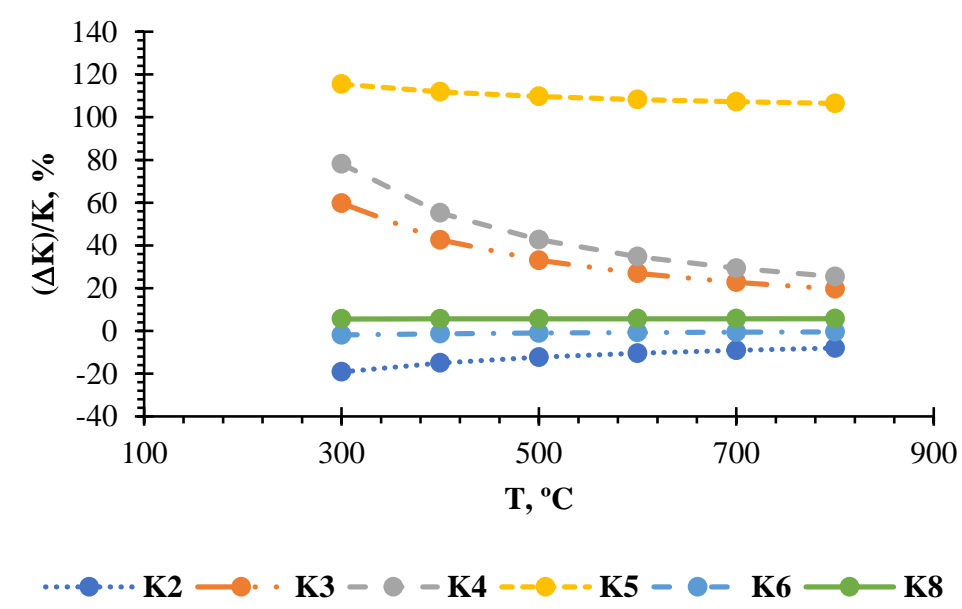

Figure 6. Kinetic differences between the root and the aerial pars of the ginseng (G7 and G8, respectively) $K_{2}$ : cellulose gasification, $\mathrm{K}_{3}$ : lignin gasification, $\mathrm{K}_{4}$ : lignin char formation, $\mathrm{K}_{5}$ : lignin char gasification, $\mathrm{K}_{6}$ : cellulose char formation and $\mathrm{K}_{8}$ : cellulose char gasification.

\subsection{Solid characterization}

In the previous sections, it was shown that a pre-treatment modifies how the sample behaves during a slow pyrolysis. A modification that may be due to changes in biomass structure. However, these alterations only are a hypothesis that should be checked. To do so, X-ray Powder Diffraction and Differential Scanning Calorimetry analyses were performed for the nine ginseng samples. The results for the DRX are collected in Table 3 , where it can be observed that the incident angle $(\theta)$ when the intensity peak was reached and/or its intensity (I) were different from the untreated sample (G7). In addition, the crystallinity index $(\mathrm{CI})$, which was calculated by the maximum intensity with a $2 \theta \in[22$, $23]$ and the minimum intensity at a $2 \theta \in[18,19]$ (Rambo \& Ferreira, 2015) (Segal et al., 1959), was different in each sample. Thus, a modification in the sample structure can be assumed since not only the incident angle and the intensity showed modifications, but also the crystallinity index, which had values between $51 \%$ and $75 \%$. It is also interesting the fact that the $2 \theta$ angle was always different from the pure crystalline cellulose I $(22.50$ and natural structure), II (21.90 and obtained from cellulose I by solubilization and polymerization), III and IV (20.70 and 22.20, respectively and generated by chemical treatments)(Ford et al., 2010). Therefore, a change in crystallinity can be also assumed by means of being part of a complex structure. Additionally, it can be checked (Table 3 


\section{Chapter 3}

and Table 2-a) that there was not a direct relation between the crystallinity and the thermal degradation kinetics because not always a bigger CI drove to a lower $\mathrm{K}_{2}$. Similarly, changes in the crystallinity index were also observed when biomass was pretreated by steam explosion (Negro et al., 2003).

Table 3. X-ray powder diffraction results from the nine ginseng samples.

\begin{tabular}{cccc}
\hline & $\begin{array}{c}2 \theta \\
\text { deg }\end{array}$ & $\mathrm{I}_{\max }$ & $\mathrm{CI}^{2}$ \\
& $\%$ \\
\hline G1 & 21.78 & 151 & 51 \\
G2 & 21.74 & 117 & 65 \\
G3 & 35.70 & 123 & 65 \\
G4 & 21.74 & 128 & 51 \\
G5 & 27.78 & 159 & 75 \\
G6 & 21.58 & 108 & 60 \\
G7 & 21.58 & 149 & 58 \\
G8 & 21.94 & 188 & 67 \\
G9 & 22.14 & 104 & 58 \\
\hline \multicolumn{4}{c}{ 1 Counts per second }
\end{tabular}

${ }^{2}$ Crystallinity index calculated by the difference between the maximum intensity with a $2 \theta \in[22,23]$ and the minimum intensity at a $2 \theta \in[18,19]$ and divided by latter maximum intensity (Rambo \& Ferreira, 2015) (Segal et al., 1959)

The same result was obtained from the DSC (Figure 7), where all the samples (less in the aerial parts since it was not pre-treated) showed an additional endothermic peak between $150{ }^{\circ} \mathrm{C}$ and $200{ }^{\circ} \mathrm{C}$. A peak that could be related to a different calorific capacity of the biomass sample due to the changes in the structure.

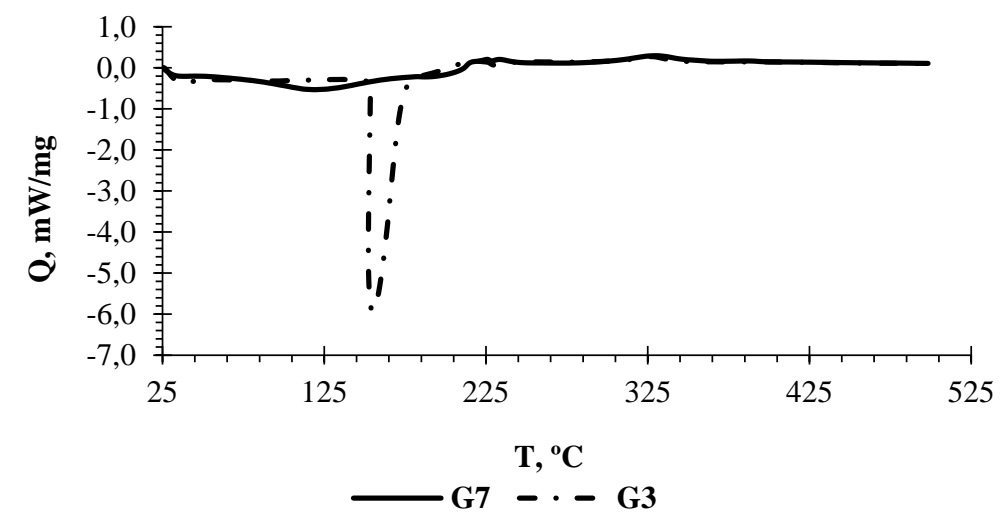

Figure 7. Comparison between the differential scanning calorimetry analysis of G3 and G7. G7: ginseng root and G3: ginseng root treated with supercritical $\mathrm{CO} 2$ and fast depressurization. 


\section{Chapter 3}

\section{Conclusions}

In this work a deep kinetic analysis of non-conventional biomass slow pyrolysis in a thermogravimetric analysis has been done. The model used, which was based on an autocatalytic kinetic expression, was able to reproduce the thermogram in oxidant atmosphere with an average absolute deviation of $4.22 \%$. From the fittings, it was observed that the calculated kinetics have several differences when different samples or pretreatment were used. One of the more remarkable result is that Brazilian ginseng roots char become extremely difficult to gasify when it is pretreated with pressurized liquids (acetyl acetate and water) at low temperatures $\left(60^{\circ} \mathrm{C}\right)$. These kinetic modifications can be related with the structural differences between the samples. Hypothesis empowered by the fact that different DSC and XRD profiles were also obtained. Therefore, these results suggest that the selection of a pretreatment/extraction step for bioactive compounds recovery should be done taking into account that it should not restrict any following step where this biomass could be used in a bio-refinery.

\section{Abbreviations and symbols}

\section{Acronyms}

AAD: average absolute deviation

C: cellulose

CI: crystallinity index

DRX: X-ray powder diffraction

DSC: differential scanning calorimetry

EXP: experimental data

G1: ginseng roots treated with acetyl acetate at 120 bar and $60^{\circ} \mathrm{C}$

G2: ginseng roots treated with water at 120 bar and $60{ }^{\circ} \mathrm{C}$

G3: ginseng roots treated with supercritical $\mathrm{CO}_{2}$ at 250 bar and $40{ }^{\circ} \mathrm{C}$ (fast depressurization) 


\section{Chapter 3}

G4: ginseng roots treated with supercritical $\mathrm{CO}_{2}$ at 250 bar and $40{ }^{\circ} \mathrm{C}$

G5: ginseng roots treated with sonicated water

G6: ginseng roots treated with water

G7: ginseng roots untreated

G8: ginseng aerial parts untreated

G9: ginseng roots treated with acetyl acetate at 120 bar and $140{ }^{\circ} \mathrm{C}$

HC: hemicellulose

I: intensity

$\mathrm{K}_{\mathrm{iGj}}=$ kinetic constant of the reaction "i $\mathrm{i}$ " for the sample $G$ ”' $j$ "

L: lignin

O: oil mass fraction

ODE: ordinary differential equation

TGA: thermogravimetric analysis

TOTAL: simulated behavior

$\mathrm{W}$ : water mass fraction

$\mathrm{XC}$ : cellulose char mass fraction

XHC: hemicellulose char mass fraction

$\mathrm{XL}$ : lignin char mass fraction

Greek letters and symbols

$\alpha_{i}$ : initial reaction rate factor, dimensionless

$\beta_{i}$ : acceleration factor, dimensionless

$c$ : heating rate correction factor, dimensionless 


\section{Chapter 3}

$C_{j}^{*}$ : equilibrium concentration of the compound " $\mathrm{j}$ " in the gas phase, $\mathrm{mol} / \mathrm{L}$

$\frac{E_{a_{i}}}{R}$ : activation energy for the reaction " $\mathrm{i}$ ”, $\mathrm{K}$

$g_{i j}$ : stoichiometric coefficient of the compound " $\mathrm{j}$ " for the reaction " $\mathrm{i}$ ", $\mathrm{g} / \mathrm{g}$

$h$ : mass transfer coefficient between the liquid and the gas phases, $\mathrm{g} \cdot \mathrm{m} \cdot \mathrm{min}^{-1} \cdot \mathrm{mol}^{-1}$

$k_{i}$ : Arrhenius' pre-exponential factor for the reaction "i”, $\min ^{-1}$

$m_{j}$ : mass fraction of the compound “ $\mathrm{j}$ ”, $\mathrm{g} / \mathrm{g}$

$N$ : number of experiments, dimensionless

$N_{r}$ : reaction number, dimensionless

$n l_{i}:$ mass transfer order for the reaction " $\mathrm{i}$ ", dimensionless

$Q$ : heat flow, $\mathrm{mW} \cdot \mathrm{mg}^{-1}$

$r_{i}$ : reaction rate for the reaction " $\mathrm{i}$ ", $\mathrm{g} \cdot \mathrm{g}^{-1} \cdot \mathrm{min}^{-1}$

$r_{j}:$ reaction rate of the compound " $\mathrm{j}$ ", $\mathrm{g} \cdot \mathrm{g}^{-1} \cdot \mathrm{min}^{-1}$

$t$ : operating time, $\min$

$T$ : operating temperature, $\mathrm{K}$

$T_{j}$ : characteristic temperature of the compound “ $\mathrm{j}$ ”, ${ }^{\circ} \mathrm{C}$

$x_{i_{E X P}}$ : experimental value of the variable " $\mathrm{X}$ " in the experiment " $\mathrm{i}$ "

$x_{i_{S I M}}$ : experimental value of the variable " $\mathrm{X}$ " in the experiment " $\mathrm{i}$ "

$Q$ : heat flow, $\mathrm{mW} \cdot \mathrm{mg}^{-1}$ 


\section{Chapter 3}

\section{Acknowledgments}

The authors acknowledge the Spanish Economy and Competitiveness Ministry, Project Reference: CTQ2015-64892-R (MINECO/FEDER) for funding. Álvaro Cabeza would like to thank to the Spanish Ministry of Education Culture and Sports, training program of university professors (reference FPU2013/01516) for the research-training contract. Diego T. Santos thanks CAPES (process 7545-15-0) and FAPESP (processes 10/164855; 12/19304-7) for the post-doctoral fellowships. M. Angela A. Meireles thanks CNPq for the productivity grant (301301/2010-7).

\section{References}

Biney, P.O., Gyamerah, M., Shen, J., Menezes, B. 2015. Kinetics of the pyrolysis of arundo, sawdust, corn stover and switch grass biomass by thermogravimetric analysis using a multi-stage model. Bioresource Technology, 179, 113-122.

Cabeza, A., Piqueras, C.M., Sobrón, F., García-Serna, J. 2016. Modeling of biomass fractionation in a lab-scale biorefinery: Solubilization of hemicellulose and cellulose from holm oak wood using subcritical water. Bioresource Technology, 200, 90-102.

Cabeza, A., Sobrón, F., Yedro, F.M., García-Serna, J. 2015. Autocatalytic kinetic model for thermogravimetric analysis and composition estimation of biomass and polymeric fractions. Fuel, 148, 212-225.

Capart, R., Khezami, L., Burnham, A.K. 2004. Assessment of various kinetic models for the pyrolysis of a microgranular cellulose. Thermochimica Acta, 417(1), 79-89.

Carpenter, D., Westover, T.L., Czernik, S., Jablonski, W. 2014. Biomass feedstocks for renewable fuel production: a review of the impacts of feedstock and pretreatment on the yield and product distribution of fast pyrolysis bio-oils and vapors. Green Chemistry, 16(2), 384-406.

Chen, Q., Zhou, J., Liu, B., Mei, Q., Luo, Z. 2011. Influence of torrefaction pretreatment on biomass gasification technology. Chinese Science Bulletin, 56(14), 14491456.

Cheng, K., Winter, W.T., Stipanovic, A.J. 2012. A modulated-TGA approach to the kinetics of lignocellulosic biomass pyrolysis/combustion. Polymer Degradation and Stability, 97(9), 1606-1615. 
Daouk, E., Van de Steene, L., Paviet, F., Salvador, S. 2015. Thick wood particle pyrolysis in an oxidative atmosphere. Chemical Engineering Science, 126, 608-615.

Das, O., Sarmah, A.K. 2015. Mechanism of waste biomass pyrolysis: Effect of physical and chemical pre-treatments. Science of the Total Environment, 537, 323-334.

Elyounssi, K., Collard, F.-X., Mateke, J.-a.N., Blin, J. 2012. Improvement of charcoal yield by two-step pyrolysis on eucalyptus wood: A thermogravimetric study. Fuel, 96, 161-167.

Ford, E.N.J., Mendon, S.K., Thames, S.F., Rawlins, J.W. 2010. X-ray Diffraction of Cotton Treated with Neutralized Vegetable Oil-based Macromolecular Crosslinkers. JOURNAL OF ENGINEERED FIBERS AND FABRICS, 2(3), 1020.

Hu, M., Chen, Z., Wang, S., Guo, D., Ma, C., Zhou, Y., Chen, J., Laghari, M., Fazal, S., Xiao, B., Zhang, B., Ma, S. 2016. Thermogravimetric kinetics of lignocellulosic biomass slow pyrolysis using distributed activation energy model, Fraser-Suzuki deconvolution, and iso-conversional method. Energy Conversion and Management, 118, 1-11.

Jae, J., Coolman, R., Mountziaris, T.J., Huber, G.W. 2014. Catalytic fast pyrolysis of lignocellulosic biomass in a process development unit with continual catalyst addition and removal. Chemical Engineering Science, 108, 33-46.

Jahirul, M., Rasul, M., Chowdhury, A., Ashwath, N. 2012. Biofuels Production through Biomass Pyrolysis - A Technological Review. Energies, 5(12), 4952.

Kan, T., Strezov, V., Evans, T.J. 2016. Lignocellulosic biomass pyrolysis: A review of product properties and effects of pyrolysis parameters. Renewable and Sustainable Energy Reviews, 57, 1126-1140.

Kastanaki, E., Vamvuka, D., Grammelis, P., Kakaras, E. 2002. Thermogravimetric studies of the behavior of lignite-biomass blends during devolatilization. Fuel Processing Technology, 77-78, 159-166.

Lv, D., Xu, M., Liu, X., Zhan, Z., Li, Z., Yao, H. 2010. Effect of cellulose, lignin, alkali and alkaline earth metallic species on biomass pyrolysis and gasification. Fuel Processing Technology, 91(8), 903-909.

Mangut, V., Sabio, E., Gañán, J., González, J.F., Ramiro, A., González, C.M., Román, S., Al-Kassir, A. 2006. Thermogravimetric study of the pyrolysis of biomass 


\section{Chapter 3}

residues from tomato processing industry. Fuel Processing Technology, 87(2), 109-115.

Negro, M.J., Manzanares, P., Oliva, J.M., Ballesteros, I., Ballesteros, M. 2003. Changes in various physical/chemical parameters of Pinus pinaster wood after steam explosion pretreatment. Biomass and Bioenergy, 25(3), 301-308.

Ogawa, T., Koizumi, S., Adachi, S. 2014. Thermal analysis of drying process of durum wheat dough under the programmed temperature-rising conditions. Food and Bioproducts Processing, 92(1), 9-13.

Oudenhoven, S.R.G., van der Ham, A.G.J., van den Berg, H., Westerhof, R.J.M., Kersten, S.R.A. 2016. Using pyrolytic acid leaching as a pretreatment step in a biomass fast pyrolysis plant: Process design and economic evaluation. Biomass and Bioenergy, 95, 388-404.

Parascanu, M.M., Sandoval-Salas, F., Soreanu, G., Valverde, J.L., Sanchez-Silva, L. 2017. Valorization of Mexican biomasses through pyrolysis, combustion and gasification processes. Renewable and Sustainable Energy Reviews, 71, 509-522.

Press, W., Teukolsky, S., Vetterling, W., Flannery, B. 2007. Numerical recipes 3rd edition: The art of scientific computing.

Rambo, M.K.D., Ferreira, M.M.C. 2015. Determination of Cellulose Crystallinity of Banana Residues Using Near Infrared Spectroscopy and Multivariate Analysis. Journal of the Brazilian Chemical Society, 26, 1491-1499.

Ranzi, E., Corbetta, M., Manenti, F., Pierucci, S. 2014. Kinetic modeling of the thermal degradation and combustion of biomass. Chemical Engineering Science, 110, 212.

Ranzi, E., Cuoci, A., Faravelli, T., Frassoldati, A., Migliavacca, G., Pierucci, S., Sommariva, S. 2008. Chemical Kinetics of Biomass Pyrolysis. Energy \& Fuels, 22(6), 4292-4300.

Ru, B., Wang, S., Dai, G., Zhang, L. 2015. Effect of Torrefaction on Biomass Physicochemical Characteristics and the Resulting Pyrolysis Behavior. Energy \& Fuels, 29(9), 5865-5874.

Scott, S.A., Dennis, J.S., Davidson, J.F., Hayhurst, A.N. 2006. An algorithm for determining the kinetics of devolatilisation of complex solid fuels from thermogravimetric experiments. Chemical Engineering Science, 61(8), 23392348. 


\section{Chapter 3}

Segal, L., Creely, J.J., A.E. Martin, J., Conrad, C.M. 1959. An Empirical Method for Estimating the Degree of Crystallinity of Native Cellulose Using the X-Ray Diffractometer. Textile Research Journal, 29(10), 786-794.

Seo, D.K., Park, S.S., Hwang, J., Yu, T.-U. 2010. Study of the pyrolysis of biomass using thermo-gravimetric analysis (TGA) and concentration measurements of the evolved species. Journal of Analytical and Applied Pyrolysis, 89(1), 66-73.

Serapiglia, M.J., Cameron, K.D., Stipanovic, A.J., Smart, L.B. 2009. Analysis of Biomass Composition Using High-Resolution Thermogravimetric Analysis and Percent Bark Content for the Selection of Shrub Willow Bioenergy Crop Varieties. BioEnergy Research, 2(1), 1-9.

Serapiglia, M.J., Cameron, K.D., Stipanovic, A.J., Smart, L.B. 2008. High-resolution Thermogravimetric Analysis For Rapid Characterization of Biomass Composition and Selection of Shrub Willow Varieties. Applied Biochemistry and Biotechnology, 145(1), 3-11.

Shafizadeh, F. 1982. Introduction to pyrolysis of biomass. Journal of Analytical and Applied Pyrolysis, 3(4), 283-305.

Sharma, A., Pareek, V., Wang, S., Zhang, Z., Yang, H., Zhang, D. 2014. A phenomenological model of the mechanisms of lignocellulosic biomass pyrolysis processes. Computers \& Chemical Engineering, 60, 231-241.

Silva Filho, C.G.d., Milioli, F.E. 2008. A thermogravimetric analysis of the combustion of a Brazilian mineral coal. Química Nova, 31, 98-103.

Slopiecka, K., Bartocci, P., Fantozzi, F. 2012. Thermogravimetric analysis and kinetic study of poplar wood pyrolysis. Applied Energy, 97, 491-497.

Van de Velden, M., Baeyens, J., Brems, A., Janssens, B., Dewil, R. 2010. Fundamentals, kinetics and endothermicity of the biomass pyrolysis reaction. Renewable Energy, $35(1), 232-242$.

Vardanega, R., Carvalho, P.I.N., Albarelli, J.Q., Santos, D.T., Meireles, M.A.A. Technoeconomic evaluation of obtaining Brazilian ginseng extracts in potential production scenarios. Food and Bioproducts Processing, 101, 45-55.

Völker, S., Rieckmann, T. 2002. Thermokinetic investigation of cellulose pyrolysis impact of initial and final mass on kinetic results. Journal of Analytical and Applied Pyrolysis, 62(2), 165-177. 


\section{Chapter 3}

Williams, P.T., Besler, S. 1996. The influence of temperature and heating rate on the slow pyrolysis of biomass. Renewable Energy, 7(3), 233-250.

\section{List of tables and figures}

Table 1. Experiments data: sample, composition and atmosphere.

Table 2. Kinetics (a), mass transfer parameters (b) and AAD (c) obtained from the adjustment.

Table 3. X-ray powder diffraction results from the nine ginseng samples.

Table 4. Experiments data: sample, composition and atmosphere.

Table 5. Kinetics (a), mass transfer parameters (b) and AAD (c) obtained from the adjustment.

Table 6. X-ray powder diffraction results from the nine ginseng samples.

Figure 1. Biomass thermal cleaving reaction pathway for slow pyrolysis (Cabeza et al., 2015). Note: sub-index “i” corresponds to the specific biopolymer (HC, C or L).

Figure 2. Ginseng roots treated with ethyl acetate at 120 bar $-60{ }^{\circ} \mathrm{C}$ (a) and $140{ }^{\circ} \mathrm{C}$ (b) thermogram. W: water mass fraction, O: oil mass fraction, $\mathrm{HC}$ : hemicellulose mass fraction $\mathrm{C}$ : cellulose mass fraction, L: lignin mass fraction, $\mathrm{XHC}$ : hemicellulose char mass fraction, $\mathrm{XC}$ : cellulose char mass fraction, XL: lignin char mass fraction and TOTAL: simulated behavior.

Figure 3. Kinetic change when sample $\mathrm{G} 7$ is treated by pressurized ethyl acetate at $60{ }^{\circ} \mathrm{C}$ (a), water at $60{ }^{\circ} \mathrm{C}$ (b) and ethyl acetate at $140{ }^{\circ} \mathrm{C}$ (c). $\mathrm{K}_{2}$ : cellulose gasification, $\mathrm{K}_{3}$ : lignin gasification, $\mathrm{K}_{4}$ : lignin char formation, $\mathrm{K}_{5}$ : lignin char gasification, $\mathrm{K}_{6}$ : cellulose char formation and $\mathrm{K}_{8}$ : cellulose char gasification.

Figure 4. Kinetic change when sample $\mathrm{G} 7$ is treated by pressurized supercritical $\mathrm{CO}_{2}$ fast depressurization and by pressurized supercritical $\mathrm{CO}_{2}(\mathrm{~b}) . \mathrm{K}_{2}$ : cellulose gasification, $\mathrm{K}_{3}$ : lignin gasification, $\mathrm{K}_{4}$ : lignin char formation, $\mathrm{K}_{5}$ : lignin char gasification, $\mathrm{K}_{6}$ : cellulose char formation and $\mathrm{K}_{8}$ : cellulose char gasification. 


\section{Chapter 3}

Figure 5. Kinetic change when sample G7 is treated by sonicated water (a) and water (b) at ambient pressure. $\mathrm{K}_{2}$ : cellulose gasification, $\mathrm{K}_{3}$ : lignin gasification, $\mathrm{K}_{4}$ : lignin char formation, $\mathrm{K}_{5}$ : lignin char gasification, $\mathrm{K}_{6}$ : cellulose char formation and $\mathrm{K}_{8}$ : cellulose char gasification.

Figure 6. Kinetic differences between the root and the aerial pars of the ginseng (G7 and G8, respectively) $\mathrm{K}_{2}$ : cellulose gasification, $\mathrm{K}_{3}$ : lignin gasification, $\mathrm{K}_{4}$ : lignin char formation, $\mathrm{K}_{5}$ : lignin char gasification, $\mathrm{K}_{6}$ : cellulose char formation and $\mathrm{K}_{8}$ : cellulose char gasification.

Figure 7. Comparison between the differential scanning calorimetry analysis of G3 and G7. G7: ginseng root and G3: ginseng root treated with supercritical $\mathrm{CO} 2$ and fast depressurization. 
Chapter 3 
Chapter 4

CHAPTER 4 



\title{
Two-phase modelling and simulation of the hydrothermal fractionation of holm oak in a packed bed reactor with hot pressurized water
}

\author{
A. Cabeza, F. Sobrón, F.M. Yedro, and J. García-Serna* \\ High Pressure Processes Group, Department of Chemical Engineering and \\ Environmental Tech., University of Valladolid, 47011 Valladolid, Spain \\ *Corresponding author: Tel.: +34983184934 \\ E-mail: jgserna@iq.uva.es (J. García-Serna)
}

\section{DOI: https://doi.org/10.1016/j.ces.2015.07.024}

\begin{abstract}
Hydrothermal fractionation has been thoroughly studied in order to develop a sustainable process to recover the sugars or the biopolymers contained in biomass. However, a physico-chemical model which considers the main involved physical phenomena, like porosity variations, has not been fully developed. Thus, the objective of this work was to approach a more realistic model than other yet published, incorporating also a novel reaction pathway for biomass fractionation. It establishes that cellulose and hemicellulose begin their fractionation in the solid, breaking in water-soluble oligomers and sugar. Besides, deacetylation reactions and insoluble oligomer formation from cellulose were considered. Kinetics followed the Arrhenius' law and it has been demonstrated that an autocatalytic kinetic model can be successfully used to simulate the biomass breaking in soluble oligomers. The process was carried out in a tubular reactor charged with $5 \mathrm{~g}$ of holm oak and continuously fed with hot pressurized water. To assess the mass transfer between the solid and liquid, 4 volumetric flows $(5 \mathrm{~mL} / \mathrm{min}, 10 \mathrm{~mL} / \mathrm{min}, 20 \mathrm{~mL} / \mathrm{min}$ and $40 \mathrm{~mL} / \mathrm{min}$ ) and two particle diameters $(3 \mathrm{~mm}$ and $6 \mathrm{~mm})$ were used. In the same way, temperature was set between $175^{\circ} \mathrm{C}$ and $207^{\circ} \mathrm{C}$. The latter was the main variable due to its effect in biomass solubility and kinetics. The model was solved by the Runge-Kutta's method with $8^{\text {th }}$ order of convergence and its discretization was performed by a new modification of the orthogonal collocation method on finite elements. It was validated by fitting total organic carbon (TOC) with Absolute Average Deviation (A.A.D. between $16.3 \%$ and $55.8 \%$ ), acetic acid concentration (A.A.D. between $44.4 \%$ and $84.4 \%$ ) and $\mathrm{pH}$ profiles (A.A.D. between $5.6 \%$ and $9.7 \%$ ). Besides, the mass transfer between the
\end{abstract}


solid and the liquid was checked and the deviations of the simulation were lower than 8.5 $\%$.

Keywords: Autocatalytic kinetic, two-phase simulation, holm oak, hydrothermal fractionation, packed bed reactor.

\section{Introduction}

For several decades petrol has been used as the main source of energy and raw material. Nevertheless, it is not a sustainable source and other option will be needed in a near future. One likely option would be biomass, and several international institutions, such as the European Union or the Organisation for Economic Co-operation and Development, have shown interest about it (King, 2009; OCDE, 2009; Organisation, 2011). The general idea is to develop a hydrolysis process to obtain the sugars present in biomass, which will be converted into liquid fuels in a following process. In addition, the extraction of the biomass phenolic compounds would be interesting due to the fact that they would be used as raw material to chemical industry. Thus, biomass hydrolysis has been studied thoroughly and in different ways, such as, enzymatic hydrolysis, acid or alkaline hydrolysis (Alvarez-Vasco \& Zhang, 2013; Charles et al., 2004; Feng et al., 2012; Gao et al., 2013; Yoon et al., 2014). One of the most promising option would be the biomass fractionation by hydrothermal processes, as at subcritical conditions as at supercritical conditions, because they can extract the main fraction of these sugars only using water as reactive (Cantero et al., 2013; Garrote et al., 2002; M. Sefik Tunc, 2008; Moniz et al., 2013; Parajó et al., 2004; Rissanen et al., 2014; Zakaria et al., 2015). Subcritical conditions refer to all temperature and pressure below the critical point and, supercritical conditions, when they are beyond it (Figure 1). Focusing in water, subcritical water means a liquid at high pressure and temperature what provide it special properties, such as lower dielectric constant and densities (Asl \& Khajenoori, 2013; Franck, 1970; Kruse \& Dinjus, 2007; Teo et al., 2010). 


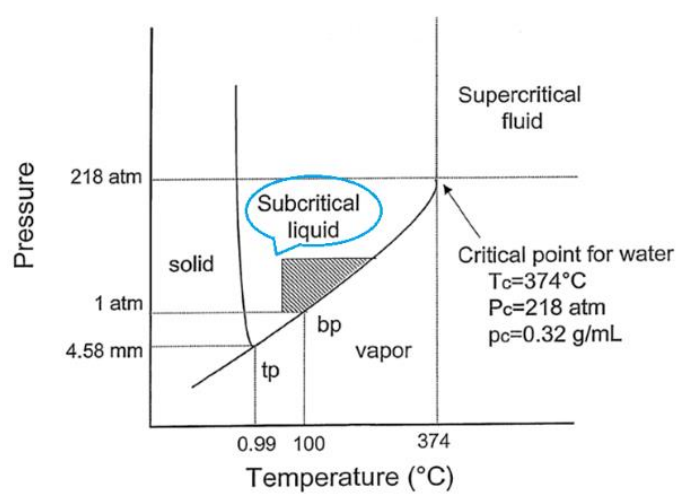

Figure 1. Phase diagram of water P-T (Asl \& Khajenoori, 2013). tp: triple point, bp: boiling point, $T_{c}, P_{c}$ and $\rho_{c}$ : critical temperature, pressure and density respectively.

Regarding modelling, some studies have been performed in order to establish a reaction pathway and kinetic equations to reproduce the experimental behaviour of the hydrolysis reactors. All of them consider that biomass is formed by three polymeric fractions: cellulose, hemicellulose and lignin. Cellulose and hemicellulose are sugar-based biopolymers and lignin is an aromatic biopolymer formed by phenylpropane units. Cellulose and hemicellulose are differentiated by their structure and composition. The former is a linear polymer constituted by hexoses and the latter is an amorphous and branched polymer of hexoses and pentoses (Bobleter, 1994; P. Harmsen, 2010). The most extended models are based on first order kinetics to cellulose and hemicellulose assuming that they decompose into intermediate oligomer products. These oligomers would continue a further bond cleavage generating the final monomeric sugars (pentose and hexoses). In addition, the degradation of these sugars into several acids can be considered (Charles et al., 2004).

Sandra Rivas et al. (Rivas et al., 2014) studied the acidic processing of hemicellulosic saccharides from pine wood and they developed a monophasic globalised kinetic model with first order kinetics respect to the biomass. That model was suitable to fit their experimental data, $\mathrm{R}^{2}$ between 0.975 and 0.998. Sasaki et al. (Sasaki et al., 2002) assessed the kinetic and mechanism of cellobiose (disaccharide composed by two glucoses) hydrolysis. This monophasic model again used first order kinetics and it could reproduce the experimental behaviour. Pronyk and Mazza (Pronyk \& Mazza, 2010) developed a kinetic model with first order kinetics to the hemicellulose hydrolysis from Triticale Strawa in a packed bed reactor, taking into account the mass transfer between solid and liquid. They assumed that two types of hemicellulose can be present, one easily degradable and other hardly degradable. They considered that the porosity of the bed 
remains constant during the process too. Jussi V. Rissanen et al. (Rissanen et al., 2014) studied the extraction of spruce hemicellulose and they developed a kinetic model which could reproduce the experimental behaviour in a cascade fluidised batch reactor, using kinetics of $\mathrm{n}^{\text {th }}$ order to solid biomass. Moreover, they also considered the proton concentration in kinetics (with $\mathrm{n}^{\text {th }}$ reaction order too) because acetic acid and other organics are produced and solved during the extraction. Therefore, there are several models which deal with biomass hydrothermal fractionation and they have obtained good results. However, they are focused in hemicellulose or cellulose fractionation and not in both of them at the same time. In addition, they do not consider some observed physical phenomena, such as, porosity changes in a bed reactor or protons effect in all kinetics in liquid phase.

Thus, the aim of this article was to develop a new kinetic model for biomass hydrothermal fractionation which could reproduce the global experimental behaviour in the most realistic way as it was possible. Trying to understand how this hydrothermal reaction takes place and analysing the effect of the particle diameter, operating temperature and liquid flow rate. So, it was taken into account the effect of $\mathrm{pH}$, porosity variations and solubility of the different biomass fractions in hot water (Kruse \& Dinjus, 2007; MillerChou \& Koenig, 2003; Teo et al., 2010) in a novel reaction pathway. The selected reactor was a tubular reactor, in order to study the process in a semi-continuous process, fed with hot pressurized water. The studied biomass was holm oak because it is one of the most common trees in the south of Spain and wastes, which could be used as raw material, are produced each year during its pruning. Regarding kinetics, a new formulation was incorporated too. An autocatalytic model is considered because it was assessed, in a previous study about biomass thermal degradation during a thermogravimetric analysis (Cabeza et al., 2015), that it can reproduce the strong mass changes in biomass at certain times or temperatures.

\section{Experimental}

\subsection{Material and methods}

\subsubsection{Raw materials}

Holm Oak branches were selected as studied biomass because it is one of the main source of woody wastes in the southern Spain. It was characterized by the National Renewable Energy Laboratory (NREL) - Determination of Structural Carbohydrates and Lignin in 
Biomass- standards. In order to check the reproducibility, the method was applied three times. The biomass was dried and milled in the selected diameters, 3 and $6 \mathrm{~mm}$. Extractives were calculated gravimetrically by Soxhlet method according to the Determination of Extractives in Biomass. The initial composition of the biomass sample is collected in Table 1. The value of the lignin includes the extractive lignin (2.36\%) and the acid soluble lignin $(1.05 \%)$.

Table 1. Initial composition of the holm oak sample

\begin{tabular}{ccc}
\hline $\begin{array}{c}\text { Cellulose } \\
\mathrm{g} / \mathrm{g}\end{array}$ & $\begin{array}{c}\text { Hemicellulose } \\
\mathrm{g} / \mathrm{g}\end{array}$ & $\begin{array}{c}\text { Lignin } \\
\mathrm{g} / \mathrm{g}\end{array}$ \\
\hline 0.4806 & 0.2060 & 0.3134 \\
\hline
\end{tabular}

All chemicals were provided by Sigma. The reactive compounds for the HPLC analysis were: cellobiose (+98\%), glucose (+99\%), fructose (+99\%), glyceraldehyde (95\%), pyruvaldehyde (40\%), arabinose (+99\%), 5-hydroxymethylfurfural (99\%), lactic acid (85\%), formic acid (98\%), acrylic acid (99\%), mannose (+99\%), xylose (+99\%), levulinic acid (+99\%) and galactose (+99\%). For analysis of carbohydrates and lignin, sulfuric acid $(98 \%)$ and calcium carbonate $(\geq 99.0 \%)$ were used. For the determination of extractives n-hexane (95\%) was selected as solvent. Distilled water was used in all assays.

\subsubsection{Experimental device}

The hydrothermal fractionation process was carried out in a semi-batch reactor charged with approx. $5 \mathrm{~g}$ of dry holm oak. To avoid particle losses two metallic filters were used, which were located at the top and bottom of the reactor. The reactor (R-01) was a microtube model SS316 piping with a length of $38 \mathrm{~cm}$ and an external diameter of $1 / 2 \mathrm{inch}$. This reactor and a preheater (E-02, AISI 316, length=200 cm, O.D.=1/8 inch) were introduced inside a chromatographic oven HP568 (F-01). The system was fed by a Jasco model PU-2080 pump (P-01) and the pressure was set using a go-backpressure valve (V01) to maintain the liquid phase. Aimed at saving energy, a concentric tube heat exchanger (E-01, 1/4"-3/8") of $70 \mathrm{~cm}$ was installed before the input oven (heat integration). Finally, a second concentric tube heat exchanger (E-03, 1/4"-3/8") of $15 \mathrm{~cm}$ was used to cool the product flow down to room temperature $\left(25-30^{\circ} \mathrm{C}\right)$. A process flow diagram of the pilot plant is shown in Figure 2. 


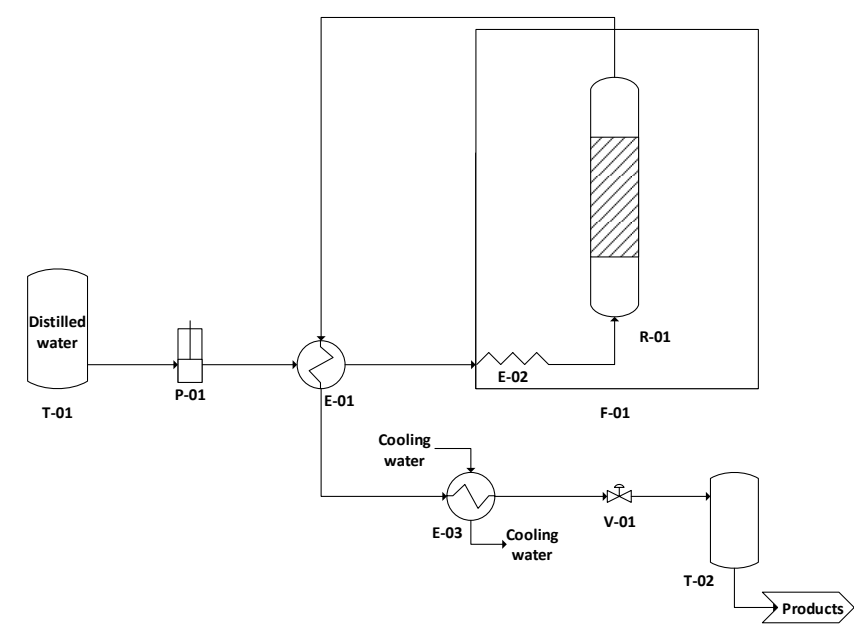

Figure 2. Process flow diagram of the pilot plant. T-01: feed water tank, P-01: feed pump, E-01: heat recover, F-01: oven. E-02: feed preheater, R-01: packed bed reactor. E-03: cooler, V-01: backpressure valve and T-02: sample tank.

Samples of the output liquid were taken from the tank T-02 measuring $\mathrm{pH}$, total organic content (TOC) and acetic acid concentration. The solid inside of the reactor was collected and quantified too. The analytical methods are described next.

\subsubsection{Solid phase characterization. Lignin and sugar content}

The solid phase characterization was done following the method provided by the National Renewable Energy Laboratory (NREL) - Determination of Structural Carbohydrates and Lignin in Biomass. Therefore, a sample of $300 \mathrm{mg}\left(\mathrm{m}_{\mathrm{i}}\right)$ was treated with $3 \mathrm{~mL}$ of sulphuric acid $(72 \%)$ followed by an incubation of $30 \mathrm{~min}$ at $30^{\circ} \mathrm{C}$. Then, $84 \mathrm{~mL}$ of distilled water were introduced and it was incubated for one hour at $121{ }^{\circ} \mathrm{C}$. The resultant suspension was filtered under vacuum, washing with distilled water, and dried at $105{ }^{\circ} \mathrm{C}$ for $24 \mathrm{~h}$. Then, the solid was weighted $\left(\mathrm{m}_{1}\right)$ and calcined at $550{ }^{\circ} \mathrm{C}$ for $24 \mathrm{~h}$ and weighted $\left(\mathrm{m}_{2}\right)$ again. So, the acid insoluble lignin would obtained by $\left(m_{1}-m_{2}\right) / m_{i}$. The recovered liquid was used to obtain the content of acid soluble lignin by spectrophotometry, measuring the absorbance at $320 \mathrm{~nm}$ and using the recommended absorptivity at a wavelength of $30 \mathrm{l} \cdot \mathrm{g}^{-1} \cdot \mathrm{cm}^{-1}$. In addition, $30 \mathrm{~mL}$ were neutralized with calcium carbonate up to $\mathrm{pH}=6-7$ followed by a filtering using $0.2 \mu \mathrm{m}$ filters and finally analysed by high pressure liquid chromatography (HPLC). The used HPLC column was SUGAR SH-1011 (Shodex). The mobile phase was a solution of $0.01 \mathrm{~N}$ of sulfuric acid and Milli-Q water. In order to obtain the hemicelluloses, celluloses and degradation product from sugars content two detector were used: a Waters IR detector 2,414 (210 $\mathrm{nm})$ and Waters dual $\lambda$ absorbance detector 2,487 (254 nm). 


\subsubsection{Liquid phase characterization}

The hydrothermal fractionation of biomass generates a complex mixture of sugars and oligomers, which is difficult to analyse. So, an acid hydrolysis was performed to convert these oligomers into their monomeric sugars. Samples of $10 \mathrm{~mL}$ were hydrolyzed adding $4 \mathrm{~mL}$ of sulphuric acid and they were incubated for $30 \mathrm{~min}$ at $30^{\circ} \mathrm{C}$. After, $86 \mathrm{~mL}$ of distilled water were added and the sample was incubated for one hour more at $121{ }^{\circ} \mathrm{C}$. Then, it was neutralized with calcium carbonate until $\mathrm{pH}=6-7$ and filtered using $0.2 \mu \mathrm{m}$ filters. Finally, it was analysed by HPLC as explained in the before section.

In addition, the $\mathrm{pH}$ and total organic carbon (TOC) were measured. The $\mathrm{pH}$ was determined by Nahita model 903 and the TOC was measured by Shimadzu equipment model TOC-VCSH. The carbon concentration of the standard solutions corresponds to $500 \mathrm{mg} \mathrm{C} / \mathrm{L}$.

\subsection{Procedure}

\subsubsection{Effect of the volumetric flow}

The effect of the liquid flow was assessed by performing 4 experiments at different volumetric flows ( $5 \mathrm{~mL} / \mathrm{min}, 10 \mathrm{~mL} / \mathrm{min}, 20 \mathrm{~mL} / \mathrm{min}$ and $40 \mathrm{~mL} / \mathrm{min}$ ) for two intervals of temperature, one around $180{ }^{\circ} \mathrm{C}$ and another around $190{ }^{\circ} \mathrm{C}$. Pressure was maintained at 100 barg to ensure the liquid phase of the water. The aim was to analyse how the mass transfer is modified with the inflow.

\subsubsection{Effect of the particle diameter}

In order to study how the particle diameter affects to the process two diameters were used, $3 \mathrm{~mm}$ and $6 \mathrm{~mm}$. This parameter has importance because it affects directly the mass transfer and the overall process due to the changes in the solid porosity.

\subsubsection{Effect of the operating temperature}

Experiments from $175^{\circ} \mathrm{C}$ and $207^{\circ} \mathrm{C}$ were performed divided in three sets. One set of three cases around $180^{\circ} \mathrm{C}$, other three around $190^{\circ} \mathrm{C}$ and two at $207^{\circ} \mathrm{C}$. The idea was to analyse how small changes in temperature affect the biomass degradation in terms of solubility, as kinetics has been considered in other studies (Cantero et al., 2013; Rissanen et al., 2014; Sasaki et al., 2002).

All the experiments and their operational conditions are shown in Table 2. 


\section{Chapter 4}

Table 2. Operational conditions of the performed experiments

\begin{tabular}{cccccc}
\hline Experiment & $\begin{array}{c}\text { Operating Temperature } \\
{ }^{\circ} \mathrm{C}\end{array}$ & $\begin{array}{c}\text { Particle diameter } \\
\mathrm{mm}\end{array}$ & $\begin{array}{r}\text { Real flow } \\
\mathrm{mL} / \mathrm{min}\end{array}$ & $\begin{array}{c}\text { Initial mass } \\
\mathrm{g}\end{array}$ & $\begin{array}{c}\text { Operating time } \\
\mathrm{min}\end{array}$ \\
\hline 1 & 175 & 3 & 3.8 & 5.3124 & 94 \\
2 & 207 & 3 & 9.6 & 5.3207 & 94 \\
3 & 185 & 3 & 17.8 & 5.3308 & 94 \\
4 & 180 & 3 & 32.7 & 5.2603 & 94 \\
5 & 190 & 6 & 2.4 & 5.2637 & 94 \\
6 & 207 & 6 & 9.5 & 5.4993 & 94 \\
7 & 195 & 6 & 19.3 & 5.2520 & 94 \\
8 & 180 & 6 & 34.9 & 5.2207 & 94 \\
\hline
\end{tabular}

\subsubsection{Model validation}

The aim of the model is to reproduce the general behaviour of the system, considering temperature, flow, particle diameter, $\mathrm{pH}$ and the main biopolymers and oligomers during the reaction. For this reason, the TOC and the $\mathrm{pH}$ of each experiment were measured and fitted. In addition, acetic acid concentration in liquid phase was considered in the experiments with a particle diameter of $3 \mathrm{~mm}$. The latter was taking into account because this compound would be the main source of protons and, for this reason, the basis of the autohydrolysis. Sugar concentration in liquid phase was only simulated in order to check if the simulation agrees with the behaviour reported by other authors.

\section{Modelling}

\subsection{Hydrothermal degradation at subcritical conditions}

Biomass fractionation starts in solid phase with hemicellulose and cellulose cleavage into oligomers of decreasing molecular weight. In both cases, at a certain polymer length they became water-soluble, being solubilised. These solubilised oligomers suffer a further hydrolysis process and they continue degrading in smaller oligomers down to their respective monomers. Finally, these monomers (mainly reduced sugars) can break into several degradation products, such as hydroxymethylfurfural, furfural, formic acid, lactic acid and others (Alvarez-Vasco \& Zhang, 2013; Feng et al., 2012). An illustration of this hydrothermal degradation with the evolution of the solid and liquid phase with time and along the reactor is schematised in Figure 3. Once the reactor was fed, water would start to degrade and to solve biomass. Thus, it is expected that, because of this extraction, the size of the particle starts to decrease, starting in the feed of the reactor. The reactor 
behaved like a fixed bed extraction column, thus, solid is depleted from bottom to top and liquid is more concentrated at the outlet (top exit in this case).

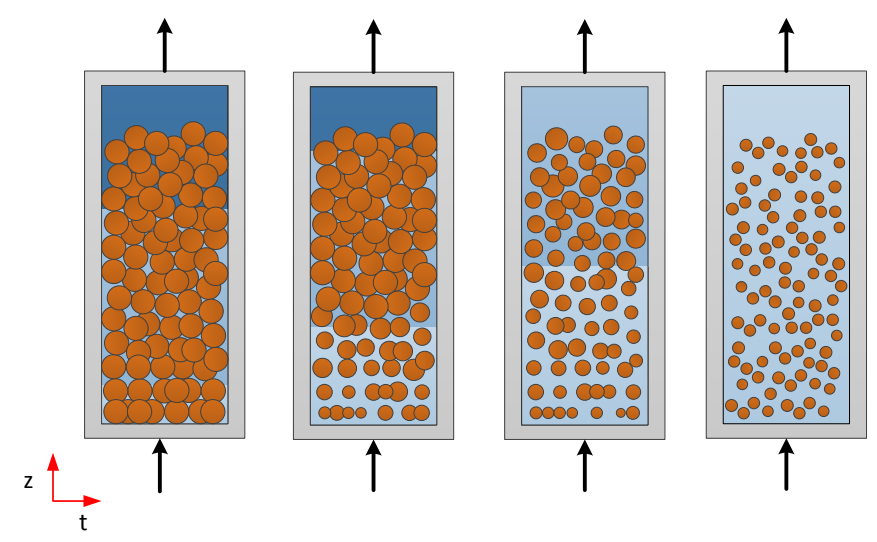

Figure 3. Expected behaviour in liquid and solid phase inside the hydrothermal reactor.

\subsection{Biomass solubility}

The solubility of polymers in water mainly depends on three factors: molecular weight, crystallinity and amount of active groups. The higher the crystallinity and the molecular weight are, the lower the solubility is. However, concentration of active groups enhances water solubility (Miller-Chou \& Koenig, 2003). Cellulose is insoluble in water due to its crystallinity and its low acetylation degree, so only oligomers with a very low molecular weight would be water soluble. Nevertheless, at high temperatures water dielectric properties have a tremendous change which could enhance cellulose solubility (Franck, 1970; Kruse \& Dinjus, 2007; Teo et al., 2010). For example, its relative value changes, at $25 \mathrm{MPa}$, from 83 at $25^{\circ} \mathrm{C}$ to 43 at $207^{\circ} \mathrm{C}$, and from 81 to 33 at the same temperatures and 100 bar. In contrast, hemicellulose has a lot of acetyl groups in its structure and it is amorphous. So, it is expected that hemicellulose oligomers with high molecular weight could be solubilised. On the other hand, lignin is a complex structure and some parts could be soluble.

\subsection{Autohydrolysis}

Another process that takes place in the reactor is the deacetylation of hemicellulose (Garrote et al., 2002; Parajó et al., 2004) and cellulose (Gao et al., 2013), which release acetic acid from de solid to the liquid phase. This emission of acetic acid implies a higher amount of protons in the liquid phase, enhancing the hydrolysis reactions in this phase. 


\section{Chapter 4}

\subsection{Reaction pathway}

The reaction mechanism is shown in Figure 3. The idea was to develop a pathway which would be able to represent the main phenomenological steps of the process, i.e. the biomass solubilisation and the sugars formation. To this end, for each cellulosic fraction two oligomers were used, one to represent the first soluble oligomer and other to symbolize the last oligomer before sugar production, which would correspond to the dimer. In addition, the deacetylation of hemicellulose and cellulose were added. The formation of an insoluble oligomer from cellulose was introduced aimed at taking into account those cellulose fractions that could not decompose into sugars at the operating conditions and the char formation from cellulose polymer. Besides, a proton consumption reaction was introduced because at the start of the operation $\mathrm{pH}$ increments were observed. So, it is assumed that certain amount of inorganic compounds with basic behaviour was present in biomass. This value was initially fixed at $1 \%$ in order to provide enough substance to the neutralization but without disturbing the initial composition a lot. The solubilisation of cellulose and hemicellulose at high temperatures was added too. The formation of degradation products was not taking into account because its value at the operational conditions was very low and they could not be quantified feasibly. Finally, hexoses (C6) formation from cellulose and hemicellulose was also considered. 


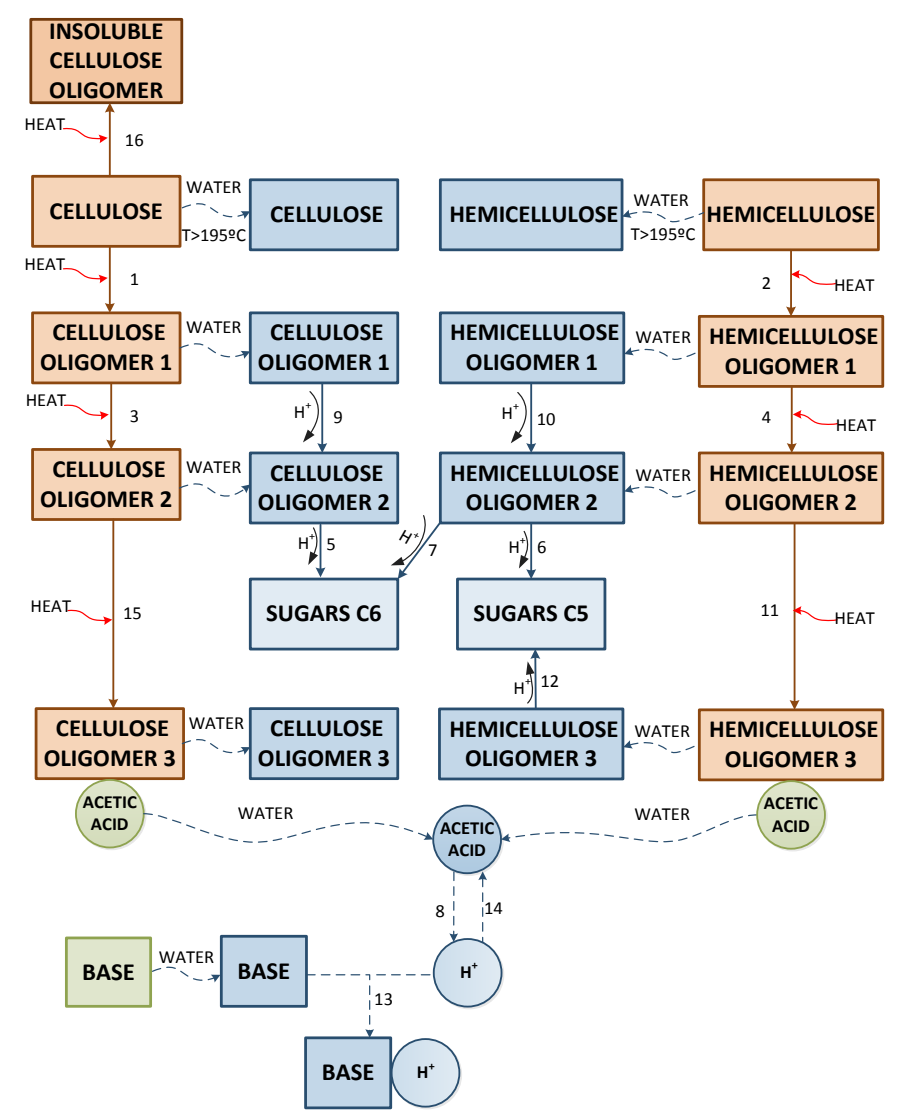

Figure 4. Reaction pathway for the cellulosic fraction of biomass.

\subsection{Kinetic model}

\subsubsection{Assumptions}

In order to simplify the modelling the following assumptions were done:

- The solid phase is homogeneous and uniform and it behaves as a whole. Thus, there are neither temperature nor concentration profiles within the solid along the reactor.

- The solid porosity only depends on the total concentration of the solid phase.

- There are not significant diffusional effects in the solid or liquid phase.

- Lignin behaves as an inert, taking as negligible the $2.36 \%$ of soluble lignin measured.

- The reaction order for all the kinetics is 1 for the biomass compound. In liquid phase, it is also considered that the kinetics depend on protons concentration with order 1. 


\section{Chapter 4}

\subsubsection{Solid phase balances}

The model of the fractionation used a non-stationary mass balance for each compound present in biomass assuming that the concentration in the solid could be calculated as the product of the liquid equilibrium concentration and an equilibrium constant $\left(C_{S_{j}}=H_{j}\right.$. $C_{L_{j}}^{*}$ ), see Eq. ( 1 ):

$$
\frac{d(1-\varepsilon) \cdot C_{S_{j}}}{d t}=r_{j}-k_{j} \cdot a \cdot\left(C_{L_{j}}^{*}-\bar{C}_{L_{j}}\right)
$$

Taking into account that the porosity was defined by Eq. ( 2 ), Eq . ( 1 ) could be rewritten in Eq. ( 3 ).

$$
\mathcal{E}=1-\varphi \cdot C_{t}
$$

$$
\frac{d C_{S_{j}}}{d t}=\frac{1}{1-\varepsilon} \cdot\left[r_{j}-\varphi \cdot C_{S_{j}} \cdot \frac{d C_{t}}{d t}-k_{j} \cdot a \cdot\left(C_{L_{j}}^{*}-\bar{C}_{L_{j}}\right)\right]
$$

For the inert compound the mass balance is shown in Eq. ( 4 ).

$$
\frac{d(1-\varepsilon) \cdot\left(C_{t}-\sum_{j=1}^{j=N} C_{S_{j}}\right)}{d t}=0
$$

\subsubsection{Liquid phase balances}

In the same way that in the solid phase, the model was obtained by the non-stationary mass balance for each compound present in this phase, see Eq. ( 5 ).

$$
\frac{\partial \mathcal{E} \cdot C_{L_{j}}}{\partial t}+\frac{u}{L} \cdot \frac{\partial C_{L_{j}}}{\partial z}=r_{j}+k_{j} \cdot a \cdot\left(C_{L_{j}}^{*}-\bar{C}_{L_{j}}\right)
$$

And Eq. ( 5 ) could be transformed in Eq. ( 6 ) by introducing the definition of the porosity, given in Eq. ( 2 ).

$$
\frac{\partial C_{L_{j}}}{\partial t}=\frac{1}{\varepsilon} \cdot\left[r_{j}-\frac{u}{L} \cdot \frac{\partial C_{L_{j}}}{\partial z}-\varphi \cdot C_{L_{j}} \cdot \frac{d C_{t}}{d t}+k_{j} \cdot a \cdot\left(C_{L_{j}}^{*}-\bar{C}_{L_{j}}\right)\right]
$$




\section{Chapter 4}

\subsubsection{Kinetics}

The kinetics for each compound in both phases are given by the generic Eq. ( 7 ).

$$
r_{j}=\sum_{i=1}^{i=n_{\text {reac }}} \Phi_{i, j} \cdot r_{i}
$$

The reaction velocity followed an autocatalytic model, see equation ( 8 ). This type of kinetic expression was selected because it has been shown by others authors (Capart et al., 2004) and in a previous work about biomass thermal degradation (Cabeza et al., 2015) that it is able to reproduce big mass changes during a fractionation or depolymerisation process. The parameter $\alpha_{i, j}$ is the initialization factor, and it is used to provide an initial value to the reaction velocity. In this case, it would be a measure of the biomass resistance against fractionation. It was fixed at 0.99 because it is the most recommended (Capart et al., 2004). On the other hand, $\beta_{i, j}$ is the acceleration factor and it represents how fast the mass change is once the decomposition process has started. In this work, it was used to represent the continuous breaking of cellulose and hemicellulose in oligomers of decreasing molecular weight.

$$
r_{i}=k_{i} \cdot \prod_{j=1}^{j=N} C_{f_{j}} \cdot\left(1-\alpha_{i, j} \cdot \frac{C_{f_{j}}}{C_{f_{t}}}\right)^{\beta_{i, j}}
$$

Eq. ( 8 ) was also used to simulate the deacetylation reactions considering that they have a first order dependence with oligomer concentration and an autocatalytic correction with hemicellulose and cellulose (Eq. ( 9 )). The latter was used in order to introduce the effect of the biomass degradation in the releasing of acetic acid.

$$
r_{i}=k_{i} \cdot\left(1-\alpha_{i, C e l} \cdot \frac{C_{C e l}}{C_{t}}\right)^{\beta_{i, C e l}} \cdot\left(1-\alpha_{i, H c e l} \cdot \frac{C_{\text {Hcel }}}{C_{t}}\right)^{\beta_{i, H c e l}} \cdot C_{S_{L O}}
$$

All the expressions from Eq. ( 1 ) to ( 9 ) were used in mass basis. So, the stoichiometric coefficients shown in Eq. ( 7 ) were in mass basis too. For this reason, their absolute value is one except to the acetic acid production and protons formation reactions. In the former, it was assumed that for 1,000 $\mathrm{mg}$ g of oligomer $300 \mathrm{mg}$ of acetic acid are produced. For the latter, it was used a relation of $17 \mathrm{mg}$ of released proton per 1,000 $\mathrm{mg}$ of acetic acid. 


\subsection{Discretisation method}

It can be observed in the section 3.5 that partial derivate equations (PDE) were used. So, a discretization method along the length of the reactor was needed. The selected method was to divide the length of the reactor in several finite elements and, inside of each of them, to apply the orthogonal collocation method. This method was mainly selected due to the fact that it requires less points (so, less calculating time) than a conventional finite differences method (Press et al., 2007; Villadsen \& Stewart, 1995). Generally, the use of finite elements implies a checking of the continuity equation between the limits of each element (Carey \& Finlayson, 1975; Press et al., 2007). Nevertheless, it increases the programming necessities and calculating times. Therefore, a modification was used in this work. The idea was to consider the limits of these elements as a normal point of the orthogonal collocation in which the mass balances described in the section 0 were directly used. This modification was successfully tested in an adsorption column problem with better results than the finite differences method by comparison with the analytic solution. Once discretized the system, the obtained set of ordinary differential equation was solved by the Runge-Kutta's method with $8^{\text {th }}$ order of convergence. Because of the high number of adjustable parameters (around 48), a preliminary solution was obtained without any optimization method. It was improved by a Simplex-Nelder-Mead's method using as objective function the addition of the absolute averaged deviations (A.A.D), of the $\mathrm{pH}$, TOC and acetic acid concentration (Eq. ( 10 )).

$$
\text { A.A.D. }=\sum_{i=1}^{o} \frac{\left|x_{i_{E X P}}-x_{i_{S I M}}\right|}{x_{i_{E X P}}} \cdot 100
$$

The developed program is available for free in the web page of the research group of high pressure processes of the University of Valladolid (http://hpp.uva.es/software/). 


\section{Chapter 4}

\subsection{Process simulation}

During the optimization process, all the compounds included in the reaction pathway (Figure 4) were simulated in order to check if the whole obtained behaviour agrees with literature. Therefore, sugar and oligomer concentration evolution as in solid as in liquid phase was calculated.

\section{Results and discussion}

\subsection{Influence of operational conditions in the extraction}

The evolution of the extracted mass with the water volumetric flow is depicted in Figure 5. Data were divided into two series depending on the particle diameter. It can be perceived that there is a clear dependence of the process with liquid flow, higher the flow faster and higher extraction was. Which was expected, because the mass transfer is enhanced under those conditions. The potential relation would be also awaited due to the fact that the effect of the flow in mass transfer always tends to a certain limit. Comparing both series, it could be concluded that an increment in the particle diameter improved extraction. However, a bigger particle diameter implies, de facto, less contact area between solid and liquid. So, mass transfer would be reduced and the extraction should be worse. This discrepancy could be explained by the fact that the data at $3 \mathrm{~mm}$ of particle diameter were obtained at temperatures around $180{ }^{\circ} \mathrm{C}$ and the data at $6 \mathrm{~mm}$ around 190 ${ }^{\circ} \mathrm{C}$. Therefore, a higher temperature would enhance extraction (due to solubility and kinetic increments) and it would fade the negative effect of using a greater particle diameter. Thus, it is clear that temperature was the most important operational factor. Temperature would be also the cause of the fact that at $9.6 \mathrm{~mL} / \mathrm{min}$ the extraction had its maximum, because it was at $207^{\circ} \mathrm{C}$. In addition, at these conditions, the real effect of the particle diameter could be checked because temperature and flow were the same in both sets. The result was that a decrement in the diameter improves the extraction, which agrees with the expected behaviour. 


\section{Chapter 4}

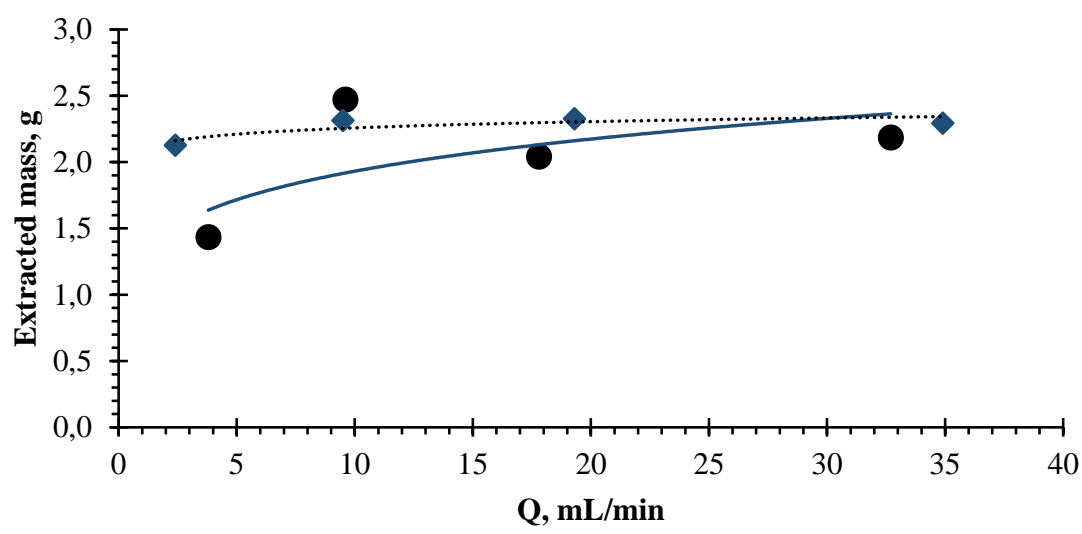

- Particle diameter $=3 \mathrm{~mm} \quad \diamond$ Particle diameter $=6 \mathrm{~mm}$

Figure 5. Extracted biomass depending on the liquid flow and particle diameter.

The variation in the maximum measured TOC with the liquid flow is shown in Figure 5. It can be seen that the higher the flow was, the lower TOC was obtained. Thus, high liquid flows mean more dilute output, which could originate problem in a post-treatment of this stream.

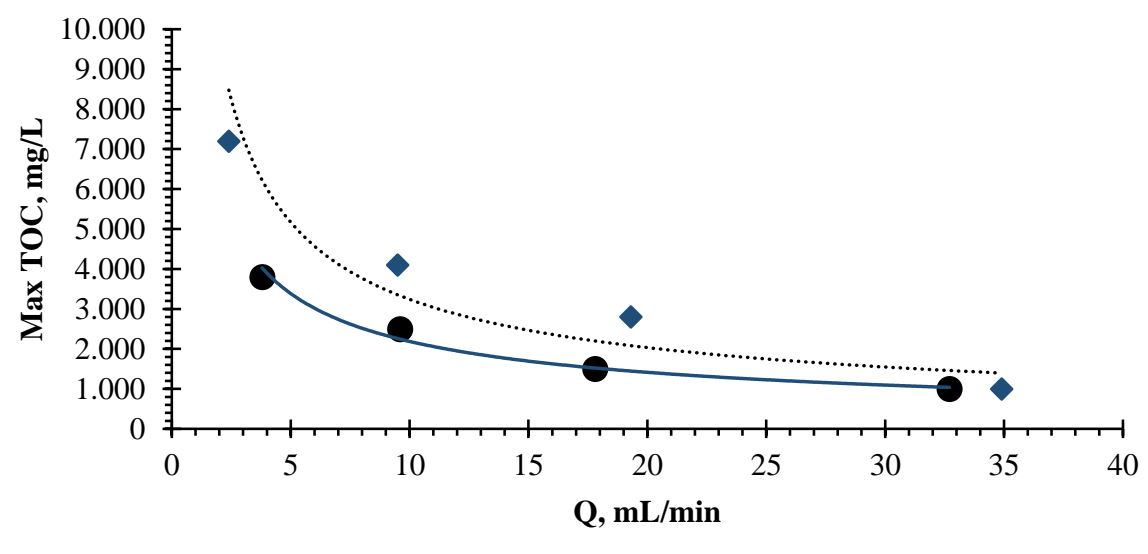

- Particle diameter $=3 \mathrm{~mm}$

$\bullet$ Particle diameter $=6 \mathrm{~mm}$

Figure 6. Maximum TOC in liquid phase depending on the liquid flow and particle diameter.

\subsection{Fittings}

A total of 8 experiments were fitted in order to validate the proposed model. The adjustments of the TOC, acetic acid concentration and $\mathrm{pH}$ for the first experiment (Table 2) are shown in Figure 7, Figure 8 and Figure 9 respectively. The simulation of the TOC was multiplied by a conversion factor in order to transform its units ( $\mathrm{mg}$ of biomass) into $\mathrm{mg}$ of carbon. This factor was calculated for each experiment by the division between the integral of the experimental TOC (using the trapezoidal method) and the real extracted mass. 


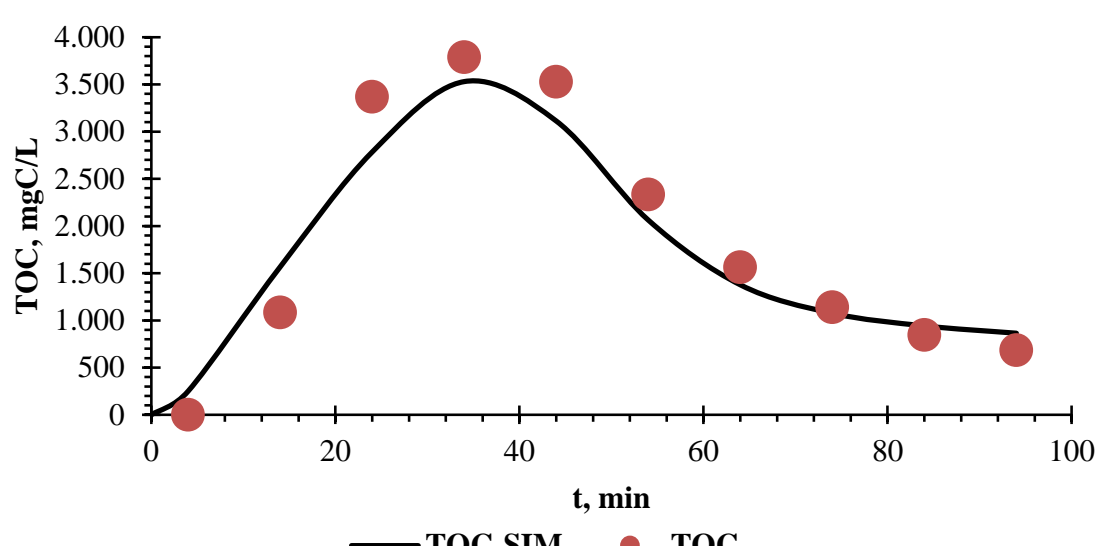

Figure 7. Fitting of the TOC for the first experience. TOC: experimental TOC; TOC-SIM: simulated TOC.

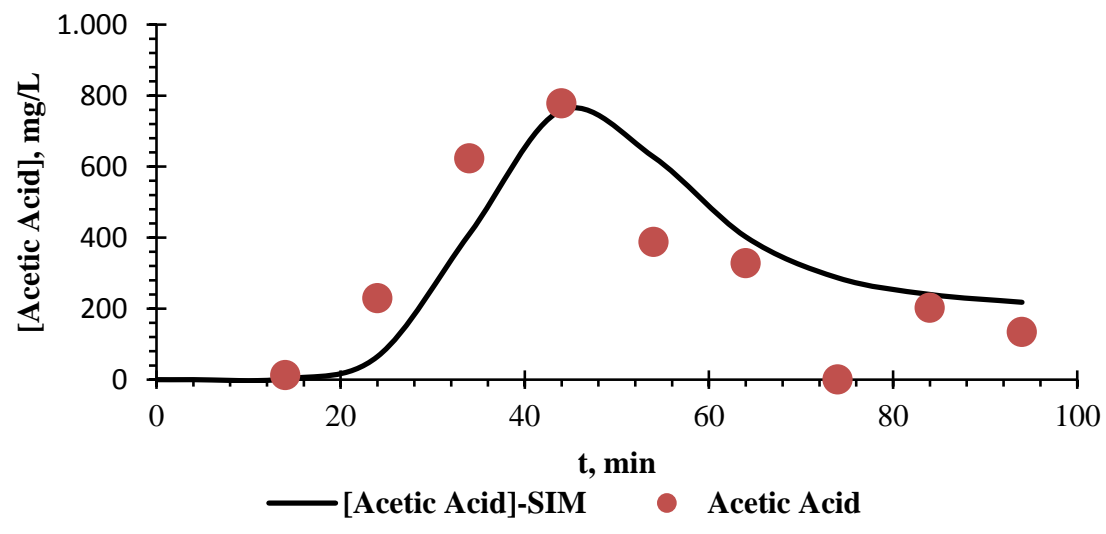

Figure 8. Fitting of the acetic acid concentration in liquid phase for the first experience. [Acetic-Acid]: experimental acetic acid concentration; [Acetic-Acid]-SIM: simulated acetic acid concentration.

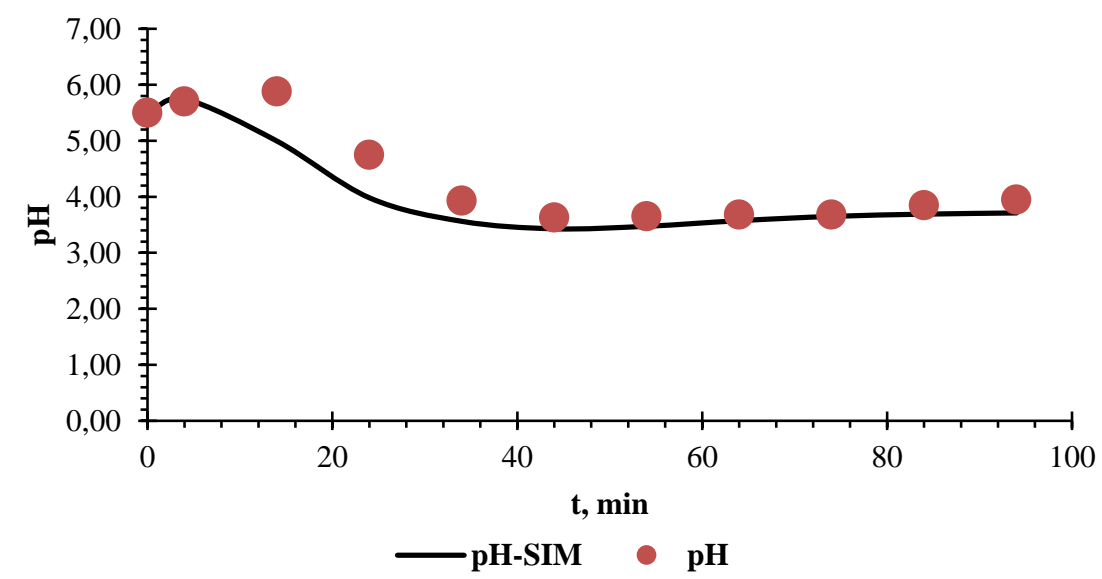

Figure 9. Fitting of the $\mathrm{pH}$ for the first experience. $\mathrm{pH}$ : experimental $\mathrm{pH}$; $\mathrm{pH}-\mathrm{SIM}$ : simulated $\mathrm{pH}$. 
Figure 7 shows that the extraction had a delay of $4 \mathrm{~min}$. Which was expected because the residence time in this experiment was relatively high $(7.8 \mathrm{~min})$ and the temperature was the lowest, $175{ }^{\circ} \mathrm{C}$. Therefore, biomass needed this $4 \mathrm{~min}$ to break until a soluble oligomer. The extraction would continue at the same velocity until 14 min when acetic acid releasing started (Figure 8). This acid production would also explain that at this time the $\mathrm{pH}$ reached a maximum (Figure 9). After this emission the extraction rate was enhanced and the TOC grew to their maximum values (time between 24 and $44 \mathrm{~min}$ ). Therefore, it was confirmed that the production of acetic acid is the main reason of the hydrothermal fractionation. From $44 \mathrm{~min}$, biomass would be highly degraded and the most soluble compound would have been yet removed. For this reason, the TOC and the acetic acid concentration started to decrease. Besides, biomass would be composed each time by compound of lower solubility, which would explain the fact that in the ending of the process the TOC decreased slowly. Finally, it is remarkable that before the acetic acid production $\mathrm{pH}$ shows an increment. This behaviour could be caused by some basic compounds present in biomass that would react with protons. As soon as acetic acid is released, this proton consumption is covered up.

It can be observed from Figure 7 to Figure 9 that the model was able to reproduce the experimental behaviour of the system in the experiment 1 . Including the slight $\mathrm{pH}$ increment in the beginning of the operation. The absolute averaged deviations (A.A.D.) between the experimental data end the simulation were calculated by equation ( 10 ). The result for each of them was TOC (16.3\%), pH (6.6\%) and acetic acid (44.4\%), values that could be acceptable due to the experimental variability of biomass. The reason of the higher discrepancy in the acetic acid concentration could be caused by the fact the experimental methods used to determinate it has a relatively low precision. However, the $\mathrm{pH}$, which depends on this concentration directly, has an error lower than $7 \%$. So, the acetic acid prediction was assumed as correct.

The rest of experiments were also fitted and their A.A.D. are arrayed in Table 3. 


\section{Chapter 4}

Table 3. Fittings A.A.D.

\begin{tabular}{cccc}
\hline \multirow{2}{*}{ Experiment } & $\begin{array}{c}\text { A.A.D. } \\
\text { TOC }\end{array}$ & $\begin{array}{c}\text { A.A.D. } \\
\mathrm{pH}\end{array}$ & $\begin{array}{c}\text { A.A.D. Acetic acid } \\
\text { concentration }\end{array}$ \\
& $\%$ & $\%$ & $\%$ \\
\hline 1 & 16.3 & 6.6 & 44.4 \\
2 & 20.8 & 9.3 & 84.4 \\
3 & 23.4 & 5.7 & 45.7 \\
4 & 55.8 & 8.8 & 49.5 \\
5 & 24.9 & 6.4 & $*$ \\
6 & 16.7 & 6.8 & $*$ \\
7 & 44.2 & 5.6 & $*$ \\
8 & 54.8 & 9.7 & $*$ \\
\hline
\end{tabular}

From the data collected in Table 2 and Table 3 it can be concluded that the higher the flow was, the higher errors in TOC and acetic acid concentration were. Which could be originated by a loss of precision in the experimental method due to the higher dilution of the samples (Figure 5). Other possible reason would be the strong changes in the extraction rate due to temperature. However, the discrepancies are low taking into account the complexity of the problem.

\subsubsection{Kinetic parameters}

In order to test if the kinetic constants would follow the Arrhenius' law, a lineal regression of each of them was done (Figure 10 and Figure 11).

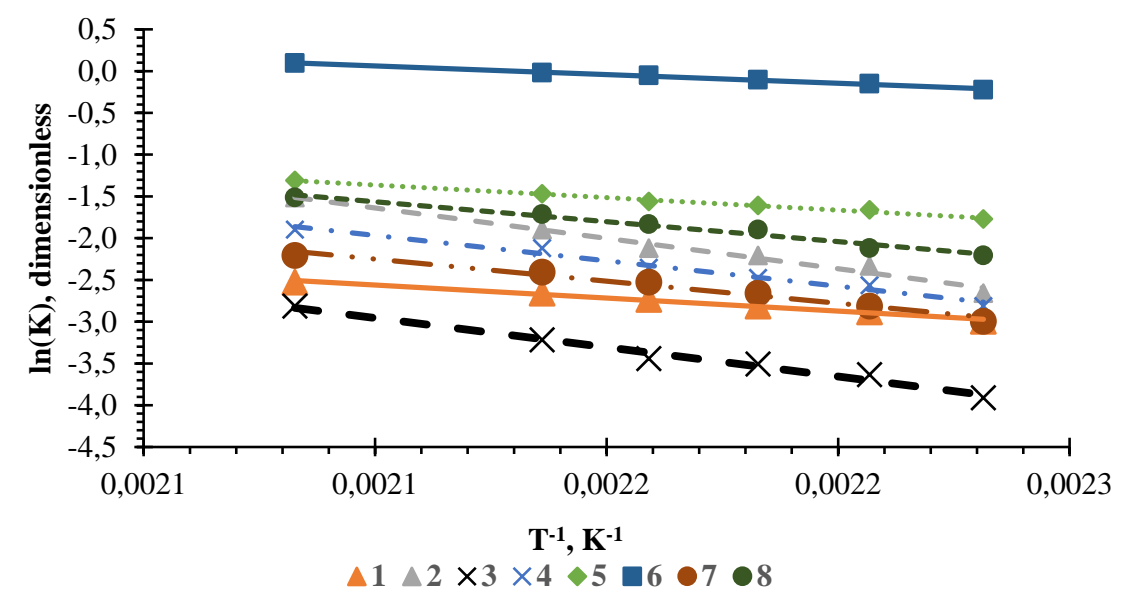

Figure 10. Linear regression for the kinetics from reaction 1 to 8 . 


\section{Chapter 4}

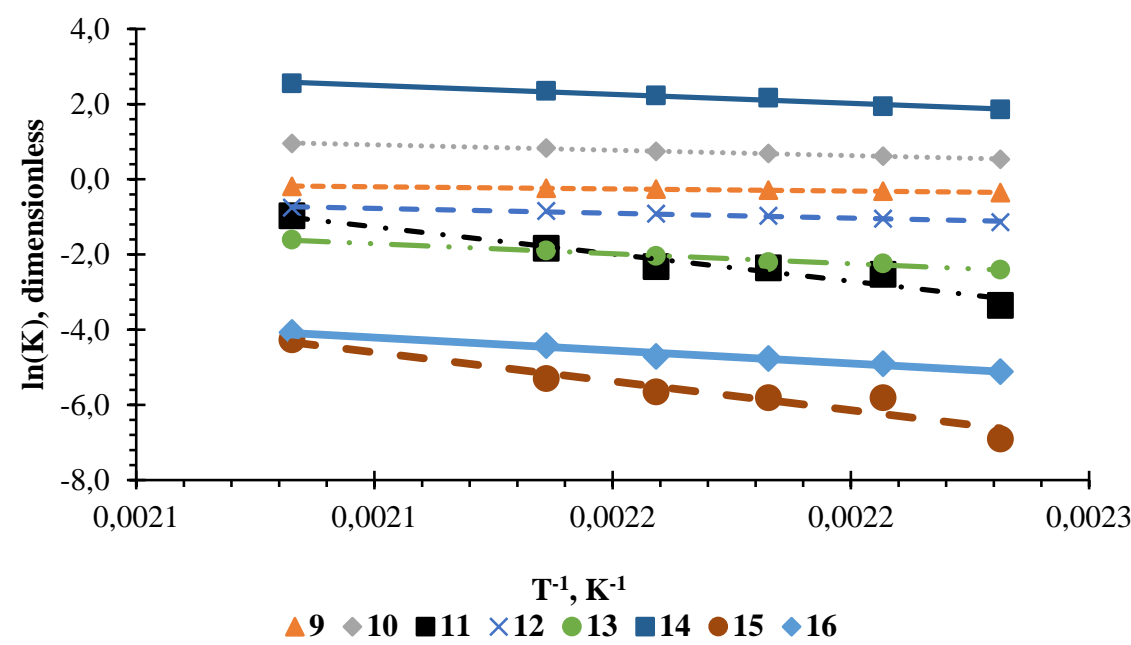

Figure 11. Linear regression for the kinetics from reaction 9 to 16 .

Table 4 shows the calculated Arrhenius' pre-exponential factor and the activation energy. In addition, the $\mathrm{R}^{2}$ of all of them was also obtained and in all the cases it was greater than 0.91. So, it was confirmed that kinetics followed the Arrhenius' law.

Table 4. Kinetic constant parameters.

\begin{tabular}{cccc}
\hline Reaction & $\ln (\mathrm{k})$ & $\mathrm{Ea} / \mathrm{R}$ & $\mathrm{R}^{2}$ \\
& & $\mathrm{~K}$ & \\
\hline 1 & 3.9904 & 3,120 & 0.994 \\
2 & 13.6340 & 7,273 & 0.982 \\
3 & 11.7530 & 7,004 & 0.980 \\
4 & 10.7910 & 6,075 & 0.982 \\
5 & 4.9454 & 3,005 & 0.991 \\
6 & 4.4420 & 2,076 & 0.995 \\
7 & 8.8511 & 5,286 & 0.986 \\
8 & 8.4487 & 4,768 & 0.980 \\
9 & 2.1793 & 1,133 & 0.994 \\
10 & 6.9321 & 2,864 & 0.996 \\
11 & 29.1120 & 14,465 & 0.945 \\
12 & 4.6492 & 2,582 & 0.982 \\
13 & 9.4547 & 5,318 & 0.984 \\
14 & 12.5110 & 4,768 & 0.980 \\
15 & 27.7210 & 15,392 & 0.913 \\
16 & 10.2630 & 6,891 & 0.980 \\
\hline & & &
\end{tabular}




\section{Chapter 4}

Table 5 and Figure 12 show the values for the acceleration factors which were different form cero. $\beta_{1, \mathrm{Co} 1}$ and $\beta_{2, \mathrm{Co} 2}$ increased their values with temperature and flow. Which was expected because they were used to simulate the biomass breaking into oligomers of decreasing molecular weight. And, if temperature or flow are increased, this breaking would be more abrupt. So, higher acceleration factor would be needed. On the other hand, $\beta_{11, \mathrm{Co} 1}, \beta_{11, \mathrm{Co} 2}, \beta_{15, \mathrm{Co} 1}$ and $\beta_{15, \mathrm{Co} 2}$ showed the opposite behaviour. This could be caused by the fact that they were used to simulate the effect of the biomass degradation on acetic acid production. So, with higher temperatures and flows, the releasing would be faster. It is remarkable that $\beta_{11, \mathrm{Co} 1,} \beta_{11, \mathrm{Co} 2,} \beta_{15, \mathrm{Co} 1}$ and $\beta_{15, \mathrm{Co} 2}$ have the same values. This was caused by the fact that all of them represent the acetic acid formation.

Table 5. Acceleration factors.

\begin{tabular}{ccccccc}
\hline \multirow{2}{*}{ Experiment } & $\beta_{1, \mathrm{Co} 1}$ & $\beta_{2, \mathrm{Co} 2}$ & $\beta_{11, \mathrm{Co} 1}$ & $\beta_{11, \mathrm{Co} 2}$ & $\beta_{15, \mathrm{Co} 1}$ & $\beta_{15, \mathrm{Co} 2}$ \\
& - & - & - & - & - & - \\
\hline 1 & 2.2 & 9.0 & 11.0 & 11.0 & 11.0 & 11.0 \\
2 & 3.0 & 10.5 & 7.0 & 7.0 & 7.0 & 7.0 \\
3 & 4.0 & 12.0 & 4.5 & 4.5 & 4.5 & 4.5 \\
4 & 3.5 & 11.0 & 4.0 & 4.0 & 4.0 & 4.0 \\
5 & 2.5 & 10.0 & 10.0 & 10.0 & 10.0 & 10.0 \\
6 & 3.0 & 10.5 & 7.0 & 7.0 & 7.0 & 7.0 \\
7 & 4.1 & 12.5 & 4.0 & 4.0 & 4.0 & 4.0 \\
8 & 3.5 & 11.0 & 3.8 & 3.8 & 3.8 & 3.8 \\
\hline \multicolumn{6}{c}{ Co1: cellulose; Co2: hemicellulose. }
\end{tabular}

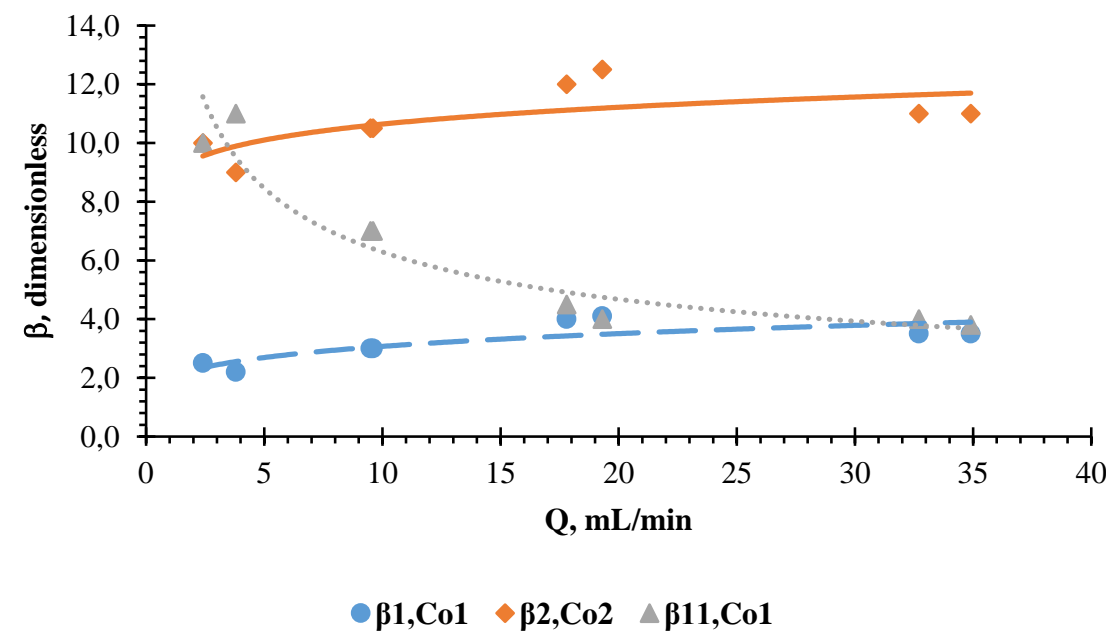

Figure 12. Acceleration factors evolution. $\beta_{11, \mathrm{Co} 1}$ was only represented because it had the same values that $\beta_{11, \mathrm{Co} 2}$, $\beta_{15, \mathrm{Co} 1}$ and $\beta_{15, \mathrm{Co} 2}$. 


\section{Chapter 4}

\subsubsection{Mass transfer parameters}

Table 6 collects the calculated values of the equilibrium constants for the soluble components at the studied temperatures. The relation with temperature was confirmed as linear by a regression analysis whose coefficient $\mathrm{R}^{2}$ was ever greater than 0.95 (Figure 13). It is remarkable that compound 1 and 2 (cellulose and hemicellulose respectively) would start to solve at temperatures greater than $195^{\circ} \mathrm{C}$. This could be explained by changes in the polarity of the water with temperature.

Table 6. Equilibrium constants (dimensionless) between solid and liquid phases.

\begin{tabular}{cccccccccc}
\hline $\begin{array}{c}\mathrm{T} \\
{ }^{\circ} \mathrm{C}\end{array}$ & $\mathrm{Co1}$ & $\mathrm{Co} 2$ & $\mathrm{Co3}$ & $\mathrm{Co} 4$ & $\mathrm{Co5}$ & $\mathrm{Co6}$ & $\mathrm{Co} 10$ & Co12 ${ }^{1}$ & $\mathrm{Co13}$ \\
\hline 190 & 0.00 & 0.00 & 0.34 & 0.40 & 0.34 & 0.52 & 3.50 & 0.15 & 0.08 \\
175 & 0.00 & 0.00 & 0.10 & 0.15 & 0.10 & 0.30 & 2.00 & 0.03 & 0.05 \\
195 & 0.15 & 0.10 & 0.40 & 0.48 & 0.40 & 0.58 & 4.00 & 0.20 & 0.09 \\
185 & 0.00 & 0.00 & 0.24 & 0.27 & 0.24 & 0.36 & 3.00 & 0.09 & 0.07 \\
180 & 0.00 & 0.00 & 0.13 & 0.16 & 0.13 & 0.30 & 2.50 & 0.06 & 0.06 \\
207 & 0.50 & 0.45 & 0.52 & 0.63 & 0.52 & 0.72 & 4.80 & 0.28 & 0.12 \\
\hline $\mathrm{R}^{2}$ & - & - & 0.9724 & 0.9715 & 0.9724 & 0.9507 & 0.9902 & 0.9886 & 0.9963 \\
\hline
\end{tabular}

Co1: cellulose; Co2: hemicellulose; Co3: cellulose oligomer 1 (first oligomer soluble from cellulose); Co4: hemicellulose oligomer 1 (first oligomer soluble from hemicellulose); Co5: cellulose oligomer 2 (last oligomer from cellulose before sugar production); Co6: hemicellulose oligomer 2 (last oligomer from hemicellulose before sugar production); Co10: acetic acid; Co12: hemicellulose oligomer 3 (deacetylated oligomer from hemicellulose); Co15: cellulose oligomer 3 (deacetylated oligomer from cellulose); Co13: base (inorganic compound). ${ }^{1}$ Compound 12 and 15 had the same equilibrium constant.

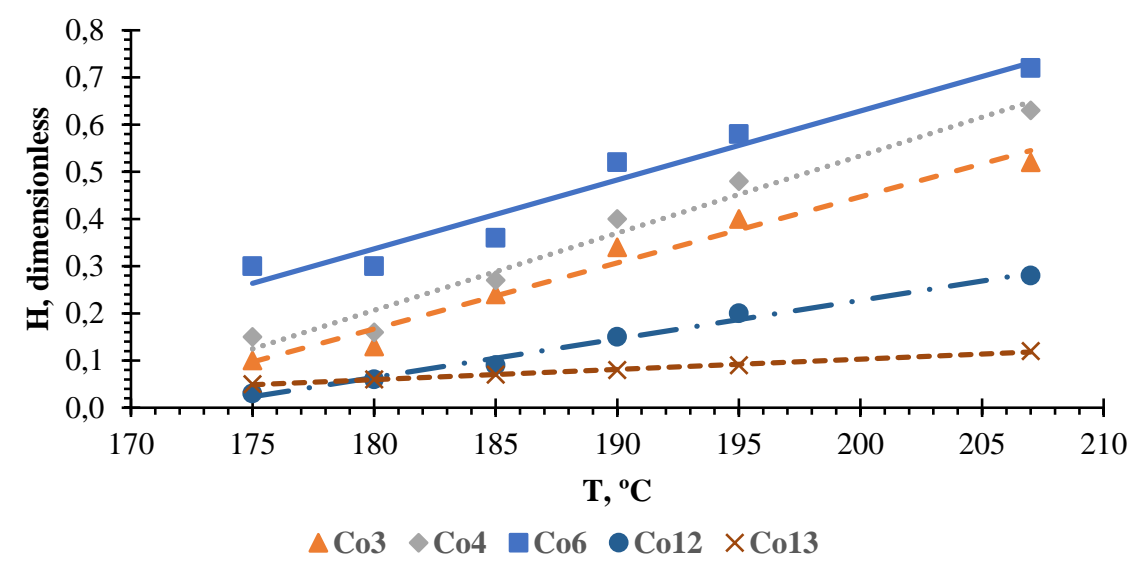

Figure 13. Equilibrium constant evolution with temperature. Compound 5 and 15 were not showed because they had the same equilibrium constant that compound 3 and 12 respectively. 


\section{Chapter 4}

Table 7 and Table 8 show the calculated mass transfer coefficients (multiplied by the specific exchange area) obtained from the adjustments. Table 7 has the parameters with a particle diameter of $3 \mathrm{~mm}$ and Table 8 with a particle diameter of $6 \mathrm{~mm}$. The necessity of use two sets of parameters would be explained by the fact that the exchange area depends on the particle diameter. In addition, it was checked the relation between them and the liquid flow. And it resulted as linear with $\mathrm{R}^{2}$ higher than 0.94 . The changes of these mas transfer coefficients are represented in Figure 14 and Figure 15 for $3 \mathrm{~mm}$ and $6 \mathrm{~mm}$ respectively.

Table 7. Mass transfer coefficients $\left(\mathrm{min}^{-1} \cdot 10^{2}\right)$ with a particle diameter of $3 \mathrm{~mm}$.

\begin{tabular}{cccccccccc}
\hline $\begin{array}{c}\mathrm{Q} \\
\mathrm{mL} / \mathrm{min}\end{array}$ & Co1 & Co2 & Co3 & Co4 & Co5 & Co6 & Co10 & Co12 & Co13 \\
\hline 3.8 & 0.0 & 0.0 & 2.6 & 15 & 2.6 & 22 & 200 & 1.5 & 0.9 \\
9.6 & 1.1 & 1.1 & 3.0 & 18 & 3.0 & 25 & 220 & 1.6 & 1.2 \\
17.8 & 0.0 & 0.0 & 4.0 & 20 & 4.0 & 27 & 340 & 1.8 & 1.5 \\
32.7 & 0.0 & 0.0 & 8.0 & 26 & 8.0 & 37 & 500 & 2.1 & 2.0 \\
\hline $\mathrm{R}^{2}$ & - & - & 0.9434 & 0.9905 & 0.9434 & 0.9795 & 0.9825 & 0.9980 & 0.9923
\end{tabular}

Co1: cellulose; Co2: hemicellulose; Co3: cellulose oligomer 1 (first oligomer soluble from cellulose); Co4: hemicellulose oligomer 1 (first oligomer soluble from hemicellulose); Co5: cellulose oligomer 2 (last oligomer from cellulose before sugar production); Co6: hemicellulose oligomer 2 (last oligomer from hemicellulose before sugar production); Co10: acetic acid; Co12: hemicellulose oligomer 3 (deacetylated oligomer from hemicellulose); Co15: cellulose oligomer 3 (deacetylated oligomer from cellulose); Co13: base (inorganic compound). ${ }^{1}$ Compound 12 and 15 had the same mass transfer coefficient.

Table 8. Mass transfer coefficients $\left(\mathrm{min}^{-1} \cdot 10^{2}\right)$ with a particle diameter of $6 \mathrm{~mm}$.

\begin{tabular}{cccccccccc}
\hline $\begin{array}{c}\mathrm{Q} \\
\mathrm{mL} / \mathrm{min}\end{array}$ & Co1 & Co2 & Co3 & Co4 & Co5 & Co6 & Co10 & Co12 ${ }^{1}$ & Co13 \\
\hline 2.4 & 0.0 & 0.0 & 2.4 & 14 & 2.4 & 20 & 180 & 1.4 & 0.8 \\
9.5 & 1.0 & 1.0 & 2.5 & 15 & 2.5 & 24 & 215 & 1.5 & 1.1 \\
19.3 & 1.5 & 1.5 & 4.5 & 16 & 4.5 & 30 & 350 & 2.0 & 1.5 \\
34.9 & 0.0 & 0.0 & 8.2 & 18 & 8.2 & 38 & 520 & 2.3 & 2.0 \\
\hline $\mathrm{R}^{2}$ & - & - & 0.9522 & 0.9978 & 0.9522 & 0.9984 & 0.9868 & 0.9583 & 0.9956
\end{tabular}

Co1: cellulose; Co2: hemicellulose; Co3: cellulose oligomer 1 (first oligomer soluble from cellulose); Co4: hemicellulose oligomer 1 (first oligomer soluble from hemicellulose); Co5: cellulose oligomer 2 (last oligomer from cellulose before sugar production); Co6: hemicellulose oligomer 2 (last oligomer from hemicellulose before sugar production); Co10: acetic acid; Co12: hemicellulose oligomer 3 (deacetylated oligomer from hemicellulose); Co15: cellulose oligomer 3 (deacetylated oligomer from cellulose); Co13: base (inorganic compound) ${ }^{1}$ Compound 12 and 15 had the same mass transfer coefficient. 


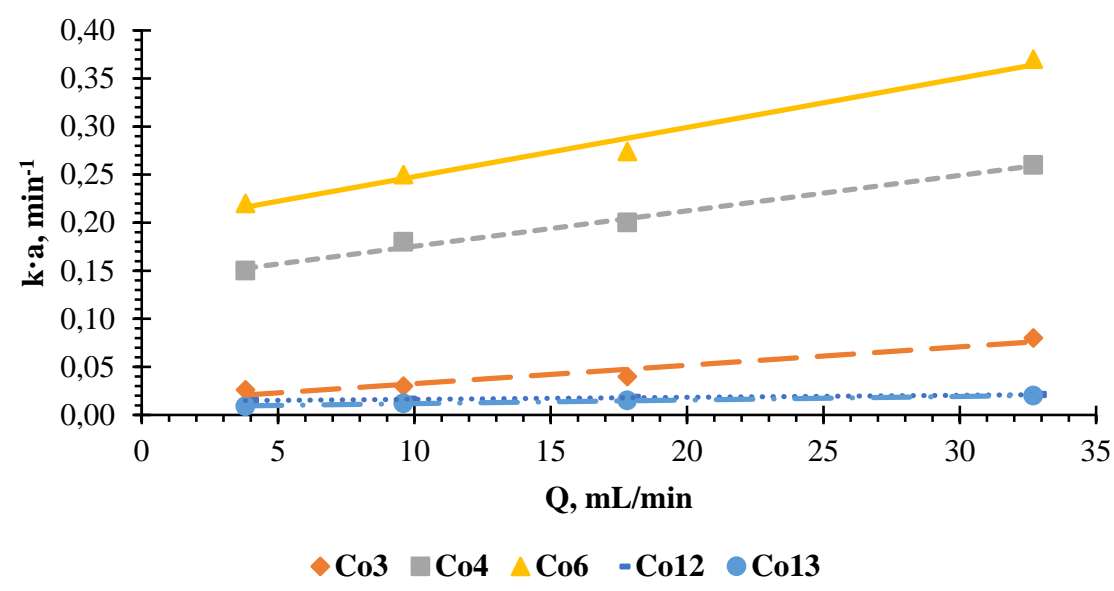

Figure 14. Mass transfer coefficients evolution with liquid flow for a particle diameter of $3 \mathrm{~mm}$. Compound 5 and 15 were not showed because they had the same mass transfer coefficient that compound 3 and 12 respectively.

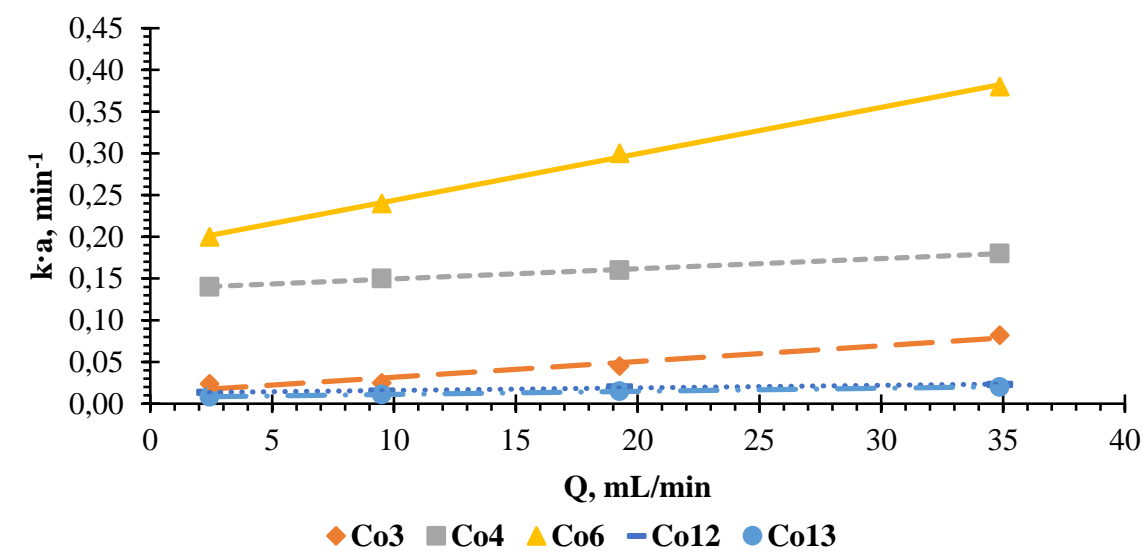

Figure 15. Mass transfer coefficients evolution with liquid flow for a particle diameter of $6 \mathrm{~mm}$. Compound 5 and 15 were not showed because they had the same mass transfer coefficient that compound 3 and 12 respectively.

\subsection{Simulated behaviour}

As it was mentioned in part 3.7, a simulation of the solid and liquid phase was performed in order to compare it with the experimental behaviour showed by others authors. In Figure 16, it is shown the breaking of cellulose in solid phase for the first experiment. It can be observed that the cellulose would decompose first into the first soluble oligomer which would break into the last oligomer before the sugar formation. In addition, this last oligomer would break into acetic acid and a deacetylated oligomer. In parallel, the formation of insoluble oligomer would take place too. At the end of the operation, cellulose would be present only as oligomers and the variation of the cellulose mas would be of $29 \%$. Hemicellulose breaking was simulated too. The behaviour was similar to the cellulose but the variation of the concentration was higher $(86 \%)$. The $14 \%$ of 


\section{Chapter 4}

hemicellulose that remained in solid would be as deacetylated oligomer due to their lower solubility.
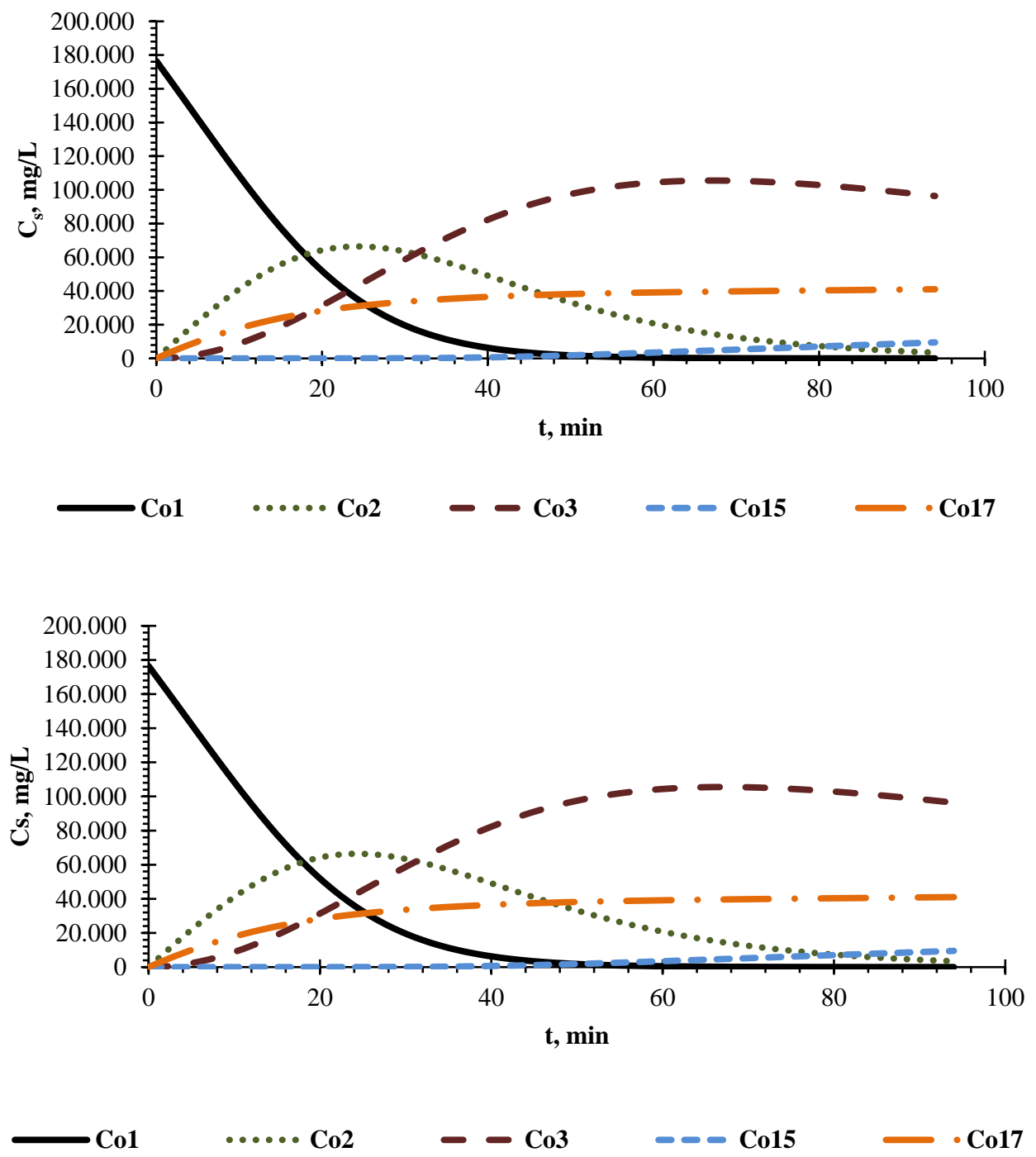

Figure 16. Cellulose breaking in solid phase. Co1: cellulose; Co3: cellulose oligomer 1 (first oligomer soluble from cellulose); Co5: cellulose oligomer 2 (last oligomer from cellulose before sugar production); Co15: cellulose oligomer 3 (deacetylated oligomer from cellulose); Co17: insoluble cellulose oligomer.

Figure 17 shows the simulation of the hemicellulose oligomers decomposition in liquid phase for the experiment 1 . It is remarkable that the main part of biomass is extracted as oligomer and that at the end of the process, only sugars would be obtained. 


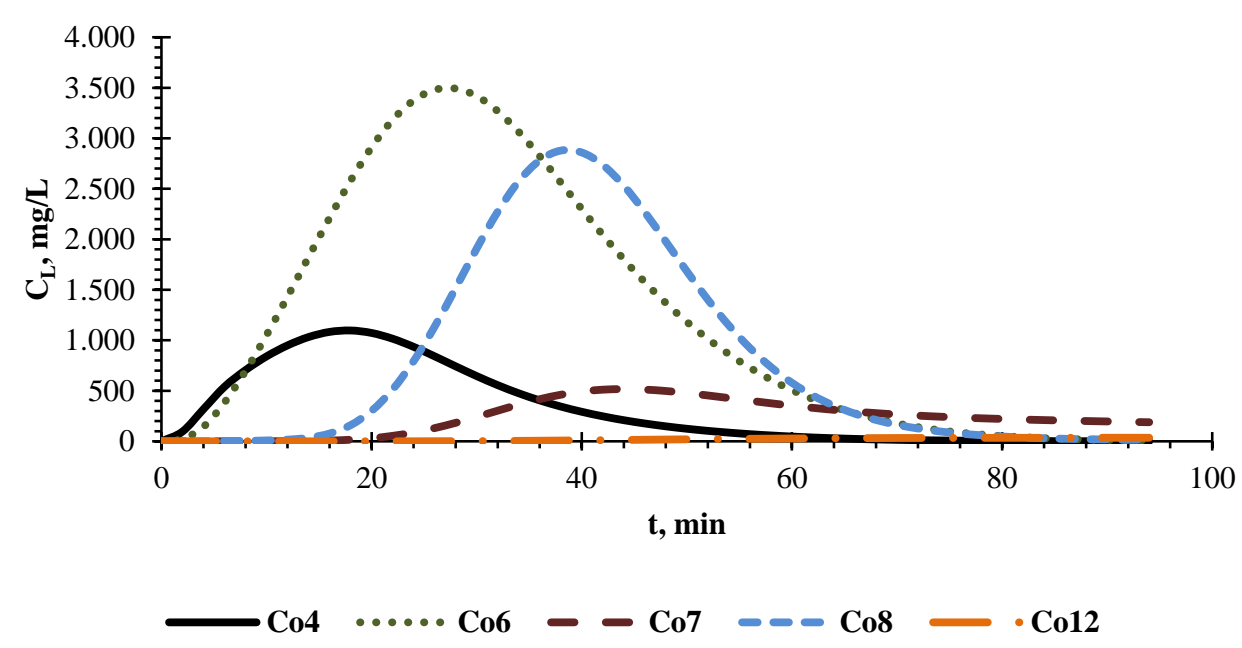

Figure 17. Hemicellulose oligomers breaking in liquid phase. Co4: hemicellulose oligomer 1 (first oligomer soluble from hemicellulose); Co6: hemicellulose oligomer 2 (last oligomer from hemicellulose before sugar production); Co7: Sugars C6; Co8: Sugars C5; Co12: hemicellulose oligomer 3 (deacetylated oligomer from hemicellulose).

The simulations of the rest of the experiments were performed too. The maximum conversion of hemicellulose and cellulose was achieved in the experiment 2,94\% and 61 $\%$, respectively. These results would be expected because it was done at the highest temperature $\left(207{ }^{\circ} \mathrm{C}\right)$ and with the lowest particle diameter $(3 \mathrm{~mm})$. In addition, it confirms the idea of temperature is the main process variable, which was also exposed in the section 4.1 .

Hemicellulose results agree with the behaviour reported by other authors. M. Sefik Tunc et al. (M. Sefik Tunc, 2008) studied the hydrothermal fractionation of hardwood biomass at $150{ }^{\circ} \mathrm{C}$ for $500 \mathrm{~min}$. They found that cellulose was not extracted at any time and that around $67 \%$ hemicellulose was recovered at $500 \mathrm{~min}$ (23\% at $100 \mathrm{~min}$ ). In addition, they reported that the main of the extracted biomass was as oligomer and that at the end of the process only monomers were obtained. Carl Pronyk et al. (Pronyk \& Mazza, 2010) assessed the hydrothermal fractionation of triticale straw also at $150{ }^{\circ} \mathrm{C}$ and they obtained similar results to M. Sefik Tunc et al. Jussi V. Rissanen et al.(Rissanen et al., 2014) analysed the hemicellulose extraction from spruce from $120^{\circ} \mathrm{C}$ to $170{ }^{\circ} \mathrm{C}$, recovering $80 \%$ of hemicellulose at $170{ }^{\circ} \mathrm{C}$ with an operating time of $50 \mathrm{~min}$. Regarding cellulose, the calculated yields were higher than the reported by other authors. Mohd Rafein Zakaria et al.(Zakaria et al., 2015) obtained yield around $15 \%$ at $180{ }^{\circ} \mathrm{C}$ and $23 \%$ at $210^{\circ} \mathrm{C}$ (both after $10 \mathrm{~min}$ of operation in batch reactor). Patrícia Moniz et al.(Moniz et al., 2013) performed experiments also in a batch reactor and the extraction of cellulose at $170{ }^{\circ} \mathrm{C}$ was $6.2 \%$ and at $200{ }^{\circ} \mathrm{C}, 9.8 \%$. These discrepancies could be explained by the fact that 
our system was a semi-continuous process, which could enhance mass transfer and cellulose breaking, with operating time longer than $10 \mathrm{~min}(94 \mathrm{~min})$. Besides, the $\mathrm{pH}$ suffered variations during the process in our reactor which could enhance the cellulose fractionation. The $\mathrm{pH}$ decreased down to 3.65 in the experiment 1 and until 3.78 in the experiment 2. In addition, it was less than 4 from $34 \mathrm{~min}$ to $94 \mathrm{~min}$ for the former and lower than 4.5 from $24 \mathrm{~min}$ to $94 \mathrm{~min}$ for the latter. Moreover, the total amount of hemicellulose in the sample was around $1 \mathrm{~g}$ and the measured extracted mass was between $1.6 \mathrm{~g}$ and $2.8 \mathrm{~g}$ (Figure 5). So, a considerable amount of cellulose should be extracted.

Finally, the mass balance between the solid and liquid phase was checked. Table 9 arrays the values of the final mass in the solid after the extraction calculated by simulation and the experimental data. The discrepancies are lower than $8.5 \%$. Besides, the average difference between the simulated and experimental final mass was $0.1189 \mathrm{~g}$ and the average soluble lignin was $0.1253 \mathrm{~g}$. Therefore, the main part of these differences (and of the TOC deviations) would be caused by this soluble lignin considered as inert.

Table 9. Comparison between the simulated and experimental final mass in the solid.

\begin{tabular}{cccc}
\hline Experiment & $\begin{array}{c}\mathrm{m}_{\text {real }} \\
\mathrm{g}\end{array}$ & $\begin{array}{c}\mathrm{m}_{\text {sim }} \\
\mathrm{g}\end{array}$ & $\begin{array}{c}\text { Discrepancy } \\
\%\end{array}$ \\
\hline 1 & 3.5656 & 3.6333 & 1.90 \\
2 & 2.5278 & 2.7324 & 8.09 \\
3 & 2.9585 & 3.0238 & 2.21 \\
4 & 2.8148 & 2.8345 & 0.70 \\
5 & 2.8736 & 3.1070 & 8.12 \\
6 & 2.6857 & 2.8498 & 6.11 \\
7 & 2.6739 & 2.7401 & 2.48 \\
8 & 2.7061 & 2.8366 & 4.82 \\
\hline
\end{tabular}

\section{Conclusions}

A kinetic model for the two-phase simulation of the hydrothermal fractionation of holm oak has been developed. The kinetic constants followed the Arrhenius' law and the mas transfer coefficients and equilibrium constants had a linear dependency with flow and temperature, respectively. This model could reproduce the TOC, $\mathrm{pH}$ and acetic acid concentration profiles with relative low deviations. These deviations were between 16.3 $\%$ and $55.8 \%$ for the TOC, $5.6 \%$ and $9.7 \%$ for the $\mathrm{pH}$ and $44.4 \%$ and $84.4 \%$ for the acetic acid. Besides, it also could simulate the behaviour in both phases (solid and liquid) in agreement with the data reported by other authors. Regarding the global mass balance, 


\section{Chapter 4}

it had a deviation always lower than $8.5 \%$. This error was mainly assumed to be since soluble lignin was not considered. It was also remarkable that cellulose extraction was much higher than expected. However, this result could be explained by the fact that the system was a semi-continuous process with high operating times and a strong $\mathrm{pH}$ decrease. Moreover, the main parameters that could affect mass transfer, e. g. particle diameter, volumetric flow and temperature, were assessed too. Amon all of them, temperature was the most important. On the other hand, it would be interesting, in a future work, to introduce the degradation product formation and the sugars production. Unfortunately, that would require to increase the number of fittings parameter even more. Therefore, another approach should be considered to perform a more detailed study. The best option would be a population model in which activation energies and oligomers solubility were a function of their molecular weight.

\section{Nomenclature}

Acronyms

Co1: Cellulose.

Co2: Hemicellulose.

Co3: Cellulose oligomer 1 (first oligomer soluble from cellulose).

Co4: Hemicellulose oligomer 1 (first oligomer soluble from hemicellulose).

Co5: Cellulose oligomer 2 (last oligomer from cellulose before sugar production).

Co6: Hemicellulose oligomer 2 (last oligomer from hemicellulose before sugar production).

Co7: Sugars C6.

Co8: Sugars C5.

Co10: Acetic acid.

Co12: Hemicellulose oligomer 3 (deacetylated oligomer from hemicellulose).

Co13: Base (inorganic compound).

Co15: Cellulose oligomer 3 (deacetylated oligomer from cellulose).

Co17: Insoluble cellulose oligomer. 


\section{Chapter 4}

TOC: Total Organic Content.

A.A.D.: Average absolute Deviation.

Subindex and superindex

pH-SIM: Simulated pH.

$\mathrm{pH}$ : Experimental $\mathrm{pH}$.

TOC-SIM: Simulated TOC.

TOC: Experimental TOC.

[Acetic acid]-SIM: Simulated acetic acid concentration.

[Acetic acid]: Experimental acetic acid concentration.

Greek letters and symbols

$\mathcal{E}$ : Porosity of the bed, dimensioless.

$C_{S_{j}}:$ Cocnetration of the compound " $\mathrm{j}$ " in the solid phase, $\mathrm{mg} / \mathrm{L}$.

$r_{j}$ : Reaction rate of the compound " $\mathrm{j}$ ”, $\mathrm{mg} / \mathrm{min} \cdot \mathrm{L}$.

$k_{j} \cdot a$ : Mass transfer coefficient multiplied by the specific exchange area, $\min ^{-1}$.

$C_{L_{j}}^{*}$ : Equilibrium concentration of the compound " $\mathrm{j}$ " in liquid phase, $\mathrm{mg} / \mathrm{L}$.

$\bar{C}_{L_{j}}$ : Average concentration of the compound " $\mathrm{j}$ " along the reactor in liquid phase, $\mathrm{mg} / \mathrm{L}$.

$H_{j}$ : Equilibrium constant between the solid and the liquid, dimensionless.

$C_{t}$ : Total concentration in the solid, $\mathrm{mg} / \mathrm{L}$.

$\varphi$ : Relation factor between porosity and the total concentration in solid phase, dimensionless.

$C_{L_{j}}$ : Concentration of the compound " $\mathrm{j}$ " in the liquid phase, $\mathrm{mg} / \mathrm{L}$.

$\Phi_{i, j}:$ Stoichiometric coefficient of the compound " $\mathrm{j}$ " for the reaction " $\mathrm{i}$ ", $\mathrm{mg}$.

$r_{i}$ : Reaction velocity “i”, $\mathrm{mg} / \mathrm{min} \cdot \mathrm{L}$.

$\alpha_{i, j}$ : Initial velocity factor for the compound " $\mathrm{j}$ " in the reaction " $\mathrm{i}$ ", dimensionless. 


\section{Chapter 4}

$\alpha_{i, C e l}:$ Initial velocity factor for cellulose in the reaction "i", dimensionless.

$\alpha_{i, \mathrm{Hcel}}$ : Initial velocity factor for hemicellulose in the reaction " $\mathrm{i}$ ", dimensionless.

$\beta_{i, j}$ : Acceleration factor for the compound " $\mathrm{j}$ " in the reaction " $\mathrm{i}$ ", dimensionless.

$\beta_{i, \mathrm{Cel}}$ : Acceleration factor for cellulose in the reaction "i", dimensionless.

$\beta_{i, \mathrm{Hcel}}$ : Acceleration factor for hemicellulose in the reaction " $\mathrm{i}$ ", dimensionless.

$k_{i}:$ Kinetic constant, $\mathrm{mg}^{-1} \cdot \mathrm{min}^{-1}$.

$C_{f_{j}}:$ Concentration of the compound "j" in the phase "f", mg/L.

$C_{C e l}$ : Concentration of cellulose in the solid phase, $\mathrm{mg} / \mathrm{L}$.

$C_{\text {Hcel }}$ : Concentration of hemicellulose in the solid phase, $\mathrm{mg} / \mathrm{L}$.

$C_{S_{L O}}$ : Concentration of the last oligomer before sugar production (from hemicellulose or cellulose) in the solid phase, $\mathrm{mg} / \mathrm{L}$.

$u$ : Liquid velocity in the reactor, $\mathrm{m} / \mathrm{min}$.

$N$ : Number of compounds, dimensionless.

$n_{r e c}$ : Number of reactions, dimensionless.

$L$ : Length of the reactor, $\mathrm{m}$.

$z$ : Coordinate along the length of the reactor, dimensionless.

$t$ : Operating time, min.

$x_{i_{E X P}}$ : Experimental value of the fitted variable.

$x_{i_{S I M}}:$ Simulated value of the fitted variable.

$o$ : Total number of experiments, dimensionless.

$k$ : Pre-exponential factor of the kinetic constant, $\mathrm{mg}^{-1} \cdot \mathrm{min}^{-1}$.

$E a / R$ : Activation energy, $\mathrm{K}$.

$R^{2}$ : Coefficient $\mathrm{R}^{2}$, dimensionless.

$T$ : Operating temperature, ${ }^{\circ} \mathrm{C}$. 
$m_{\text {real }}$ : Final solid mass, g.

$m_{\text {sim }}:$ Simulated final solid mass, g.

\section{Acknowledgements}

The authors acknowledge the Spanish Economy and Competitiveness Ministry, Project Reference: ENE2012-33613 and the regional government (Junta de Castilla y León), Project Reference: VA330U13 for funding. Álvaro Cabeza would like to thank to the Spanish Ministry of Education Culture and Sports, training program of university professors (reference FPU2013/01516) for the research training contract.

\section{References}

Alvarez-Vasco, C., Zhang, X. 2013. Alkaline hydrogen peroxide pretreatment of softwood: Hemicellulose degradation pathways. Bioresource Technology, 150, 321-327.

Asl, A.H., Khajenoori, M. 2013. Subcritical Water Extraction, Mass Transfer - Advances in Sustainable Energy and Environment Oriented Numerical Modeling. InTech.

Bobleter, O. 1994. Hydrothermal degradation of polymers derived from plants. Progress in Polymer Science (Oxford), 19(5), 797-841.

Cabeza, A., Sobrón, F., Yedro, F.M., García-Serna, J. 2015. Autocatalytic kinetic model for thermogravimetric analysis and composition estimation of biomass and polymeric fractions. Fuel, 148, 212-225.

Cantero, D.A., Bermejo, M.D., Cocero, M.J. 2013. Kinetic analysis of cellulose depolymerization reactions in near critical water. The Journal of Supercritical Fluids, 75(0), 48-57.

Capart, R., Khezami, L., Burnham, A.K. 2004. Assessment of various kinetic models for the pyrolysis of a microgranular cellulose. Thermochimica Acta, 417(1), 79-89.

Carey, G.F., Finlayson, B.A. 1975. Orthogonal collocation on finite elements. Chemical Engineering Science, 30(5-6), 587-596.

Charles, E.W., Stephen, R.D., Michael, E.H., John, W.B., Catherine, E.S., Liisa, V. 2004. Hydrolysis of Cellulose and Hemicellulose. in: Polysaccharides, CRC Press. 
Feng, Y., Qi, X., Jian, H.L., Sun, R.C., Jiang, J.X. 2012. Effect of inhibitors on enzymatic hydrolysis and simultaneous saccharification fermentation for lactic acid production from steam explosion pretreated lespedeza stalks. BioResources, 7(3), 3755-3766.

Franck, E.U. 1970. Water and aqueous solutions at high pressures and temperatures. Pure Appl. Chem, 24, 13-30.

Gao, P., Li, G., Yang, F., Lv, X.N., Fan, H., Meng, L., Yu, X.Q. 2013. Preparation of lactic acid, formic acid and acetic acid from cotton cellulose by the alkaline pretreatment and hydrothermal degradation. Industrial Crops and Products, 48, 6167.

Garrote, G., Domínguez, H., Parajó, J.C. 2002. Interpretation of deacetylation and hemicellulose hydrolysis during hydrothermal treatments on the basis of the severity factor. Process Biochemistry, 37(10), 1067-1073.

King, D. 2009. The future of industrial biorefineries. Worl Economic Forum.

Kruse, A., Dinjus, E. 2007. Hot compressed water as reaction medium and reactant: Properties and synthesis reactions. The Journal of Supercritical Fluids, 39(3), 362380.

M. Sefik Tunc, A.R.P.v.H. 2008. Hemicellulose extraction of mixed southern hardwood with water at $150{ }^{\circ} \mathrm{C}$ : Effect of time. Industrial \& Engineering Chemistry Research, 47(18), 7031-7037.

Miller-Chou, B.A., Koenig, J.L. 2003. A review of polymer dissolution. Progress in Polymer Science, 28(8), 1223-1270.

Moniz, P., Pereira, H., Quilhó, T., Carvalheiro, F. 2013. Characterisation and hydrothermal processing of corn straw towards the selective fractionation of hemicelluloses. Industrial Crops and Products, 50(0), 145-153.

OCDE. 2009. The Bioeconomy to 2030: designing a policy agenda, Vol. 2014.

Organisation, T.E.P.S. 2011. THE EUROPEAN BIOECONOMY IN 2030. Delivering Sustainable Growth by addressing the Grand Societal Challenges, pp. 1-24. 
P. Harmsen, W.H., L. Bermudez, R. bakker. 2010. Literature review of physical and chemical pretreatment processes for lignocellulosic biomass. Wageningen UR Food \& Biobased Research.

Parajó, J.C., Garrote, G., Cruz, J.M., Dominguez, H. 2004. Production of xylooligosaccharides by autohydrolysis of lignocellulosic materials. Trends in Food Science \& Technology, 15(3-4), 115-120.

Press, W., Teukolsky, S., Vetterling, W., Flannery, B. 2007. Numerical recipes 3rd edition: The art of scientific computing.

Pronyk, C., Mazza, G. 2010. Kinetic modeling of hemicellulose hydrolysis from triticale straw in a pressurized low polarity water flow-through reactor. Industrial and Engineering Chemistry Research, 49(14), 6367-6375.

Rissanen, J.V., Grénman, H., Willför, S., Murzin, D.Y., Salmi, T. 2014. Spruce hemicellulose for chemicals using aqueous extraction: Kinetics, mass transfer, and modeling. Industrial and Engineering Chemistry Research, 53(15), 63416350.

Rivas, S., González-Muñoz, M.J., Santos, V., Parajó, J.C. 2014. Acidic processing of hemicellulosic saccharides from pine wood: Product distribution and kinetic modeling. Bioresource Technology, 162, 192-199.

Sasaki, M., Furukawa, M., Minami, K., Adschiri, T., Arai, K. 2002. Kinetics and mechanism of cellobiose hydrolysis and retro-aldol condensation in subcritical and supercritical water. Industrial and Engineering Chemistry Research, 41(26), 6642-6649.

Teo, C.C., Tan, S.N., Yong, J.W.H., Hew, C.S., Ong, E.S. 2010. Pressurized hot water extraction (PHWE). Journal of Chromatography A, 1217(16), 2484-2494.

Villadsen, J.V., Stewart, W.E. 1995. Solution of boundary-value problems by orthogonal collocation. Chemical Engineering Science, 50(24), 3981-3996.

Yoon, S.Y., Han, S.H., Shin, S.J. 2014. The effect of hemicelluloses and lignin on acid hydrolysis of cellulose. Energy, 77(0), 19-24. 
Zakaria, M.R., Hirata, S., Hassan, M.A. 2015. Hydrothermal pretreatment enhanced enzymatic hydrolysis and glucose production from oil palm biomass. Bioresource Technology, 176(0), 142-148.

\section{List of tables}

Table 1. Initial composition of the holm oak sample

Table 2. Operational conditions of the performed experiments

Table 3. Fittings A.A.D.

Table 4. Kinetic constant parameters.

Table 5. Acceleration factors.

Table 6. Equilibrium constants (dimensionless) between solid and liquid phases.

Table 7. Mass transfer coefficients (min-1 102) with a particle diameter of $3 \mathrm{~mm}$.

Table 8. Mass transfer coefficients (min-1 102) with a particle diameter of $6 \mathrm{~mm}$.

Table 9. Comparison between the simulated and experimental final mass in the solid.

\section{List of figures}

Figure 1. Phase diagram of water P-T (Asl \& Khajenoori, 2013). tp: triple point, bp: boiling point, $\mathrm{T}_{\mathrm{c}}, \mathrm{P}_{\mathrm{c}}$ and $\rho_{\mathrm{c}}$ : critical temperature, pressure and density respectively.

Figure 2. Process flow diagram of the pilot plant. T-01: feed water tank, P-01: feed pump, E-01: heat recover, F-01: oven. E-02: feed preheater, R-01: packed bed reactor. E-03: cooler, V-01: backpressure valve and T-02: sample tank.

Figure 3. Expected behaviour in liquid and solid phase inside the hydrothermal reactor.

Figure 4. Reaction pathway for the cellulosic fraction of biomass.

Figure 5. Extracted biomass depending on the liquid flow and particle diameter.

Figure 6. Maximum TOC in liquid phase depending on the liquid flow and particle diameter.

Figure 7. Fitting of the TOC for the first experience. TOC: experimental TOC; TOCSIM: simulated TOC. 
Figure 8. Fitting of the acetic acid concentration in liquid phase for the first experience. [Acetic-Acid]: experimental acetic acid concentration; [Acetic-Acid]-SIM: simulated acetic acid concentration.

Figure 9. Fitting of the $\mathrm{pH}$ for the first experience. $\mathrm{pH}$ : experimental $\mathrm{pH}$; $\mathrm{pH}-\mathrm{SIM}$ : simulated $\mathrm{pH}$.

Figure 10. Linear regression for the kinetics from reaction 1 to 8 .

Figure 11. Linear regression for the kinetics from reaction 9 to 16.

Figure 12. Acceleration factors evolution. $\beta_{11, \text { Col }}$ was only represented because it had the same values that $\beta_{11, \mathrm{Co} 2,} \beta_{15, \mathrm{Co} 1}$ and $\beta_{15, \mathrm{Co} 2}$.

Figure 13. Equilibrium constant evolution with temperature. Compound 5 and 15 were not showed because they had the same equilibrium constant that compound 3 and 12 respectively.

Figure 14. Mass transfer coefficients evolution with liquid flow for a particle diameter of $3 \mathrm{~mm}$. Compound 5 and 15 were not showed because they had the same mass transfer coefficient that compound 3 and 12 respectively.

Figure 15. Mass transfer coefficients evolution with liquid flow for a particle diameter of $6 \mathrm{~mm}$. Compound 5 and 15 were not showed because they had the same mass transfer coefficient that compound 3 and 12 respectively.

Figure 16. Cellulose breaking in solid phase. Co1: cellulose; Co3: cellulose oligomer 1 (first oligomer soluble from cellulose); Co5: cellulose oligomer 2 (last oligomer from cellulose before sugar production); Co15: cellulose oligomer 3 (deacetylated oligomer from cellulose); Co17: insoluble cellulose oligomer.

Figure 17. Hemicellulose oligomers breaking in liquid phase. Co4: hemicellulose oligomer 1 (first oligomer soluble from hemicellulose); Co6: hemicellulose oligomer 2 (last oligomer from hemicellulose before sugar production); Co7: Sugars C6; Co8: Sugars C5; Co12: hemicellulose oligomer 3 (deacetylated oligomer from hemicellulose). 


\section{Chapter 4}


Chapter 5

CHAPTER 5 



\title{
Modelling of biomass fractionation in a lab-scale biorefinery: solubilization of
} hemicellulose and cellulose from holm oak wood using subcritical water

\author{
A. Cabeza ${ }^{a}$, C.M. Piqueras $^{b}$ F. Sobrón ${ }^{a}$ and J. García-Serna ${ }^{a *}$
}

${ }^{a}$ High Pressure Processes Group, Department of Chemical Engineering and Environmental Tech., University of Valladolid, 47011 Valladolid, Spain

${ }^{b}$ Planta Piloto de Ingeniería Química, PLAPIQUI-Universidad Nacional del SurCONICET, Camino La Carrindanga km 7, 8000 Bahía Blanca, Buenos Aires, Argentina. *Corresponding author: Tel.: +34 983184934

E-mail: jgserna@iq.uva.es (J. García-Serna)

\section{DOI: https://doi.org/10.1016/j.biortech.2015.09.063}

\begin{abstract}
Lignocellulose fractionation is a key biorefinery process that need to be understood. In this work, a comprehensive study on hydrothermal-fractionation of holm oak in a semicontinuous system was conducted. The aim was to develop a physicochemical model in order to reproduce the role of temperature and water flow over the products composition. The experiments involve two sets: at constant flow $(6 \mathrm{~mL} / \mathrm{min})$ and two different ranges of temperature (140-180 ${ }^{\circ} \mathrm{C}$ and $240-280{ }^{\circ} \mathrm{C}$ ) and at a constant temperature range (180$260{ }^{\circ} \mathrm{C}$ ) and different flows: $11.0,15.0$ and $27.9 \mathrm{~mL} / \mathrm{min}$. From the results, temperature has main influence and flow effect was observed only if soluble compounds were produced. The kinetic model was validated against experimental data, reproducing the total organic carbon profile (e.g. deviation of $33 \%$ ) and the physico-chemical phenomena observed in the process. In the model, it was also considered the variations of molecular weight of each biopolymer, successfully reproducing the biomass cleaving.
\end{abstract}

Keywords: Holm oak, hydrothermal fractionation, subcritical water, biorefinery, modelling. 


\section{Chapter 5}

\section{Introduction}

The concept of biorefinery is based on the definition of a conventional petroleum refinery. Therefore, it is an installation which transforms a raw material (biomass) into energy (heat, electricity and biofuels) and several products (chemicals and biomaterials) by fractionation or conversion processes. One of the most studied ways to perform this conversion is biomass pyrolysis, where heat is used to transform it into charcoal, gases and biofuels (Ranzi et al., 2008; Tanoue et al., 2007; Tock et al., 2010). On the other hand, hydrothermal fractionation is another promising option because it is capable to recover the cellulosic fraction of biomass, which corresponds between $38.3 \mathrm{wt} \%$ and 81.3 wt\% of woody biomass (Bobleter, 1994; Yedro et al., 2015), using only water as reactive. This technique has been highly studied and various articles can be found in literature (Charles et al., 2004; Mohan et al., 2015; Pronyk \& Mazza, 2010; Rogalinski et al., 2008). However, the modelling of this process is an issue which still has not a final solution due to biomass complexity, which is formed by three main compounds: hemicellulose, cellulose and lignin. Cellulose and hemicellulose are polysaccharides composed by up to 10,000 and 200 monomers, respectively. The former is a linear biopolymer with a high degree of crystallinity formed by hexoses (C6) and the latter is amorphous and it is constituted by hexoses and pentoses (C5). On the other hand, lignin is an aromatic biopolymer formed by phenylpropane units (Bobleter, 1994; P. Harmsen, 2010). In addition, biomass diversity and the process monitoring also complicate the development and validation of a kinetic model. The first issue can be seen in Yedro et al., 2015 who studied the fractionation of several wood species in a semi-continuous reactor. They observed that the extraction yields were very different between the species although the qualitative behavior of all of them were similar. Regarding monitoring, the problem would be that the analysis of the samples must be done at different conditions from which were used during the operation. The reason is that the characterization requires wet chemical analysis followed by a separation of the different fractions by conventional analytical instruments at certain conditions (Carrier et al., 2011). Therefore, some measured values would be different from the real during the operation.

To sum up, it is not clear that a model with a single set of kinetic parameters could be used as a global solution for biomass solubilization. Nevertheless, several models for this process, with a reasonable success, can be found in literature (Haghighat Khajavi et al., 2005; Lin et al., 2015; Mohan et al., 2015; Rogalinski et al., 2008; Zhu et al., 2014). Zhu 
et al., 2014 studied the hydrolysis of peanut shell in subcritical water in a batch reactor. They proposed a kinetic model with a $1^{\text {st }}$ reaction order respect to biomass concentration which was able to reproduce their experimental data. In the same way, Mohan et al., 2015 and Lin et al., 2015 assessed the hydrolysis of real biomass (bamboo and rice straw respectively) in a batch reactor and they also fitted their data applying a $1^{\text {st }}$ order kinetic. Rogalinski et al., 2008 performed a successful kinetic analysis of the starch hydrolysis in a plug-flow reactor assuming a $1^{\text {st }}$ reaction order. And Khajavi et al., 2005 studied the hydrolysis of sucrose in a flow-type reactor but taking into account the effect of the $\mathrm{pH}$ variations during the process. All of them were based on the idea that the cellulosic fractions of biomass (cellulose and hemicellulose) decompose into sugar. This sugar formation could be from an intermediate product (oligomers) or directly from biomass. The formation of degradation products, such as formic or lactic acid, from these sugars was also considered. Nevertheless, they were generally applied to a batch system or they studied model compounds, like sucrose. Besides, they did not take into account the whole set of physical phenomena observed during a hydrothermal treatment of biomass: deacetylation/autohydrolysis/pH variations and solid-liquid mass transfer/porosity variations. In addition, a previous work (Cabeza et al., 2015) was done to reproduce the behavior of a hemicellulose extraction process from holm oak (one of the most common trees in southern Spain) considering all these phenomena. The study was performed in a packed bed reactor with hot compressed water and the effect of different particle diameters and flow rates was also assessed. Temperature was fixed around $180^{\circ} \mathrm{C}$ in order to enhance hemicellulose extraction. The result was a model able to reproduce the Total Organic Carbon (TOC), $\mathrm{pH}$ and acetic acid concentration at the reactor output with average absolute deviations of $32.1 \%, 7.4 \%$ and $56.0 \%$ respectively. Nevertheless, the effect of the molecular weight, the oligomer distribution and high temperature effect were not considered with this model.

Therefore, the objective of this work is to complete this preliminary kinetic model for the holm oak hydrothermal fractionation in a semi-continuous system (packed bed reactor) with hot compressed water. This model will be able to reproduce the experimental data including the effect of the molecular weight and all the physical phenomena observed. Besides, it will also capable of simulating the oligomer distribution and reproducing the variations in the fractionation when high and low temperatures are used. The latter was done performing a temperature change during the process. So, the extraction of the whole 


\section{Chapter 5}

cellulosic of biomass at subcritical conditions has been studied. The idea was to perform experiments at two temperatures, one between $140^{\circ} \mathrm{C}$ and $180^{\circ} \mathrm{C}$, in order to enhance hemicellulose extraction, and the other between $240{ }^{\circ} \mathrm{C}$ and $280{ }^{\circ} \mathrm{C}$ to recover the main cellulose fraction. An autocatalytic kinetic was used being suitable to reproduce the fractionation in the previously mentioned study. Thus, this model will help to understand better the fractionation process. In addition, it will allow to simulate how a change in the reactor diameter or length would affect the fractionation and how would be the solid composition evolution, which could be an important factor to stop the process. To sum up, this model will be a useful tool to perform a future scale-up of this lab-scale biorefinery.

\section{Materials and Methods}

\subsection{Experimental setup}

The experimental device used in this work is shown in Figure 1. The whole system consisted in a fractionation column whose output stream feeds a supercritical hydrolysis reactor. This setup belongs to a bigger project and it was constructed with the aim to study other biomass transformations (e.g enhancement of sugars yield and optimizing the selectivity to fully hydrolyzed products, coming from cellulose or from real biomass). However, for this work only the fractionation column was used. The system was composed of a water deposit (T-1) followed by an American Lewa EK6 2KN high pressure pump (P-1, maximum flow rate $1.5 \mathrm{~kg} / \mathrm{h})$ and a pre-heater $(\mathrm{H}-1,200 \mathrm{~cm}$ of 1/8" SS 316 pipe, electrically heated by 2 resistances of $300 \mathrm{~W}$ ) used to maintain a constant temperature at the inlet of the fractionation column (R-1, a SS 316 tube of $40 \mathrm{~cm}$ length and $1.27 \mathrm{~cm}$ O.D.). In addition, the column was heated by three flat resistors of $500 \mathrm{~W}$ placed along an aluminum device which contains the column. The preheater and the column were inside a chromatographic oven HP5680 for security reasons.

On the other hand, the supercritical water line was composed by another tank of water (T-2), a heater (H-2, a SS316 tube of $20 \mathrm{~m}$ with 1/8 in O.D.) with two flat resistors, total power of $5 \mathrm{~kW}$ and a Milton Roy XT membrane pump (P-2, maximum flow rate $6 \mathrm{~kg} / \mathrm{h}$ ). Pressure was controlled by a Micro Metering valve 30VRMM4812 from Autoclave Engineering (V-4). The output of the reactor (R-2) was cold down in the heat exchanger H-3 (200 cm of concentric tube $1 / 2$ in- $1 / 4$ in) with cold water and then it was collected in the tank T-4. 


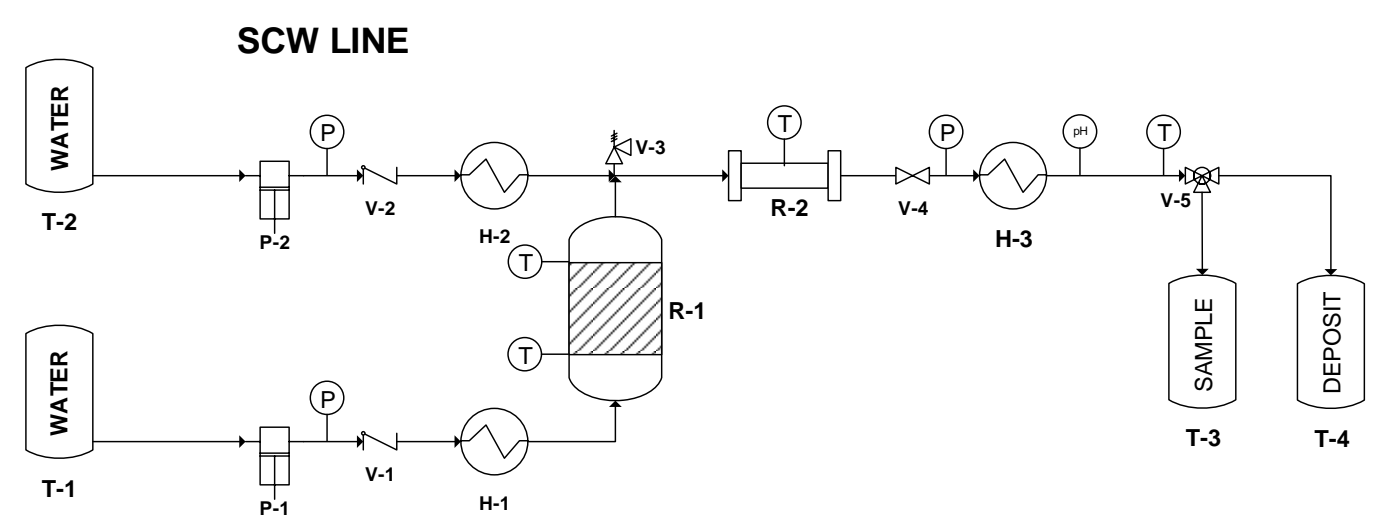

EXTRACTION LINE

Figure 1. Process flow diagram of the experimental device. T-1 and T-2: type II Millipore water tanks, P-1: High pressure piston pump. P-2: membrane pump, V-1 and V-2: Parker check valve. H-1: electric low temperature heater. H-2: high temperature heater. R-1: fractionation column. V-3: Parker relieve valve. R-2: supercritical reactor. V-4: high temperature valve, HE: cooling heat exchanger. V-5: three way Parker valve, T-3: Falcon flasks. T-4: products deposit.

\subsection{Procedure}

$6.12 \pm 0.03 \mathrm{~g}$ of holm oak were introduced into the fractionation column. Two metallic filters were used, one located in the top and the other in the bottom, to keep the raw material inside. In order to check if any leak was present in the fractionation line, cold water was pressurized into the system before each experiment. Then, the flow was stopped and the preheater and the fractionation column were heated up. When the desired value was achieved the pumps were started adjusting the flow and pressure with $\mathrm{V}-4$. In order to monitoring the process, $\mathrm{pH}$ evolution was followed online (each minute) using an electronic pH-meter (Nahita model 903). Also, liquid samples were taken between 220 min (in tank T-3), depending on the $\mathrm{pH}$ value. During the operation, two temperatures were used. The change between them was done depending on the value of the monitored $\mathrm{pH}$, because of the fact that there is a relation between the $\mathrm{pH}$ value and the extracted biomass. So, if the $\mathrm{pH}$ variation is slow, biomass has reached its maximum solubilization at that temperature and the temperature change is done (Figure 2-b). 
a)

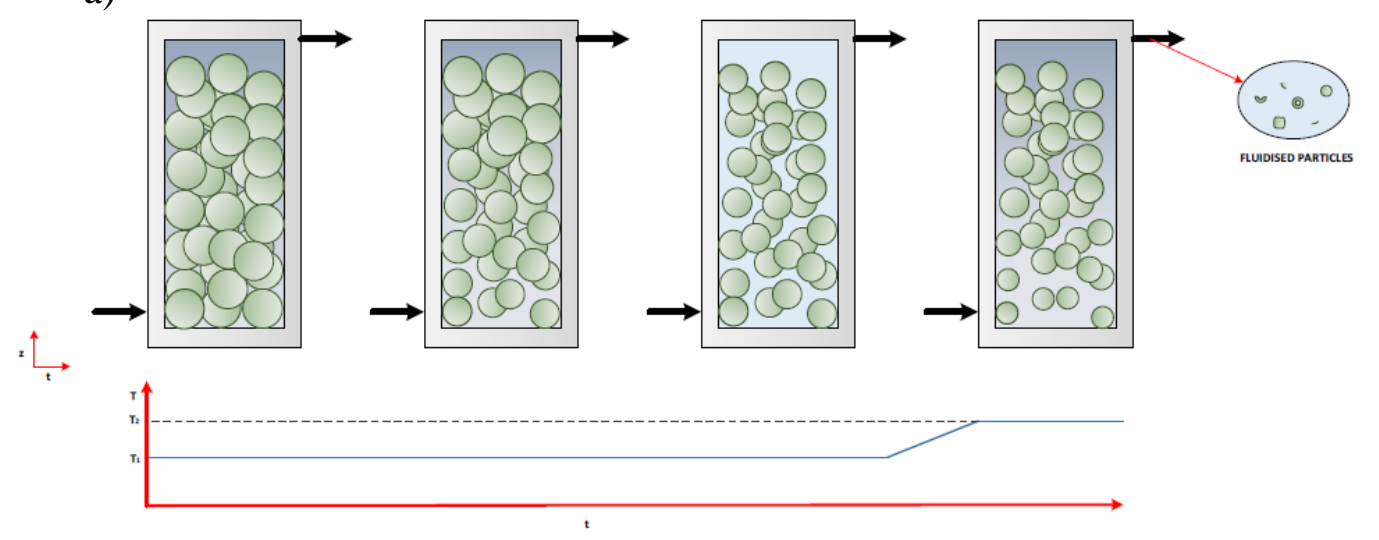

b)

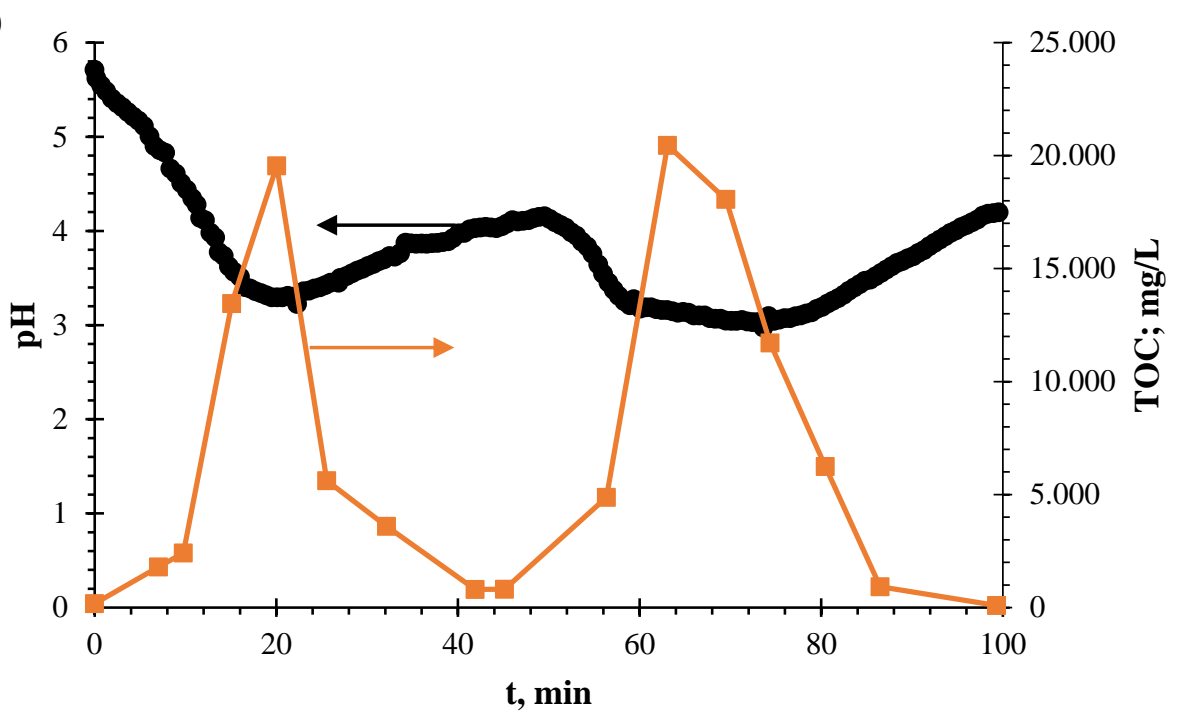

Figure 2. Scheme of the hydrothermal degradation of biomass at two temperatures (a) and pH evolution during the process (b).

Once the operation was over, the heating was shut off and the fractionation column was gradually cooled down to room temperature with air flux. Both pumps were disconnected and the system was depressurized. The solid inside of the reactor was collected, filtered and dried $24 \mathrm{~h}$ at $105^{\circ} \mathrm{C}$ for further analysis. Finally, the column was cleaned and reconnected to the system, which was washed with Type II water.

\subsubsection{Effect of the temperature}

In previous studies it has been seen that temperature is the main influencing variable on this type of process. For this reason, 8 different temperatures $\left(140{ }^{\circ} \mathrm{C}, 150{ }^{\circ} \mathrm{C}, 160{ }^{\circ} \mathrm{C}\right.$, $180{ }^{\circ} \mathrm{C}, 240{ }^{\circ} \mathrm{C}, 250{ }^{\circ} \mathrm{C}, 260{ }^{\circ} \mathrm{C}$ and $280{ }^{\circ} \mathrm{C}$ ) were studied in this work. Besides, the same sample was treated at two different temperature levels in order to extract first the 


\section{Chapter 5}

hemicellulose at the lowest temperature and then the cellulose at the highest temperature. The volumetric flow was fixed around $6 \mathrm{~mL} / \mathrm{min}$ and the operating pressure was $15 \mathrm{MPa}$.

\subsubsection{Effect of the volumetric flow}

Other variable that have a high effect in the biomass solubilization is the volumetric flow. This was studied by performing experiments at 3 different flows $(11.0 \mathrm{~mL} / \mathrm{min}, 15.0$ $\mathrm{mL} / \mathrm{min}$ and $27.9 \mathrm{~mL} / \mathrm{min})$ at the same temperatures $\left(180{ }^{\circ} \mathrm{C}-260{ }^{\circ} \mathrm{C}\right)$.

\subsubsection{Model validation}

In order to validate the model, TOC, sugars, acetic acid and degradation product concentration at the output of the column were measured and fitted. The adjustment was focused in TOC because it would be the most precise measure. This would be caused by the high dilution (Table 1) of the samples due to the fact that during the operation both pumps must be working (Figure 1). Besides, the final mass inside the reactor was simulated and compared with the experimental data. In addition, the overall behavior of the system was simulated. To achieve these objectives the experiments arrayed in Table 1 were performed.

Table 1. Experiments performed and its operational conditions.

\begin{tabular}{|c|c|c|c|c|}
\hline & Volumetric flow & Sampling volumetric flow & Range of Temperatures & Operating time \\
\hline & $\mathrm{mL} / \mathrm{min}$ & $\mathrm{mL} / \mathrm{min}$ & ${ }^{\circ} \mathrm{C}$ & $\min$ \\
\hline 1 & 6.5 & 22.8 & $180-280$ & 99 \\
\hline 2 & 6.2 & 22.5 & $160-260$ & 120 \\
\hline 3 & 7.8 & 23.4 & $150-250$ & 160 \\
\hline 4 & 6.9 & 21.1 & $140-240$ & 200 \\
\hline 5 & 6.5 & 23.1 & $180-260$ & 110 \\
\hline 6 & 11.5 & 37.7 & $180-260$ & 110 \\
\hline 7 & 15.0 & 100.8 & $180-260$ & 60 \\
\hline 8 & 27.0 & 106.8 & $180-260$ & 46 \\
\hline
\end{tabular}




\section{Chapter 5}

\subsection{Analytical methods}

\subsubsection{Solid characterization}

The solid phase characterization was done following the method provided by the National Renewable Energy Laboratory (NREL) - Determination of Structural Carbohydrates and Lignin in Biomass. Firstly, biomass suffered an extraction performed in a Soxhlet equipment by $\mathrm{n}$-hexane. After, a sample of $300 \mathrm{mg}(\mathrm{m})$ was treated with $3 \mathrm{~mL}$ of sulphuric acid (72 wt \%) for $30 \mathrm{~min}$ at $30^{\circ} \mathrm{C}$. Then, the sample was diluted by $84 \mathrm{~mL}$ of distilled water and it was maintained at $120^{\circ} \mathrm{C}$ for one hour more. The result was filtered under vacuum, washed by distilled water and dried at $105^{\circ} \mathrm{C}$ for $24 \mathrm{~h}$. Then, the solid was weighted $\left(\mathrm{m}_{1}\right)$ and calcined at $550{ }^{\circ} \mathrm{C}$ for $24 \mathrm{~h}$ and weighted $\left(\mathrm{m}_{2}\right)$ again. Thus, the acid insoluble lignin was obtained by $\left(m_{1}-m_{2}\right) / m$. The obtained liquid was used to determinate the content of acid soluble lignin by spectrophotometry, measuring the absorbance at 320 $\mathrm{nm}$ (recommended absorptivity $34 \mathrm{~L} \cdot \mathrm{g}^{-1} \cdot \mathrm{cm}^{-1}$ ). Moreover, $30 \mathrm{~mL}$ of sample were neutralized up to $\mathrm{pH}=6-7$ with calcium carbonate and they were filtered by $0.2 \mu \mathrm{m}$ filters. Finally, this sample was analysed by high pressure liquid chromatography (HPLC). The used HPLC column was SUGAR SH-1011 (Shodex). As mobile phase a 0.01N sulfuric acid solution and Milli-Q water were used. To obtain the hemicellulose, cellulose and degradation product content two detector were used: a Waters IR detector 2,414 (210 nm) and Waters dual $\lambda$ absorbance detector 2,487 (254 $\mathrm{nm})$. The calculated initial composition of the biomass sample was: $1.81 \mathrm{wt} \%$ of extractives with $\mathrm{n}$-hexane, $46.64 \mathrm{wt} \%$ of cellulose, $24.48 \mathrm{wt} \%$ of hemicellulose, $27.07 \mathrm{wt} \%$ of lignin and $0.28 \mathrm{wt} \%$ of ash. The value of the lignin included the soluble lignin $(4.32 \%)$.

\subsubsection{Liquid characterization}

An acid hydrolysis was performed to the liquid phase in order to convert the oligomers into their monomeric sugars. Samples of $10 \mathrm{~mL}$ were hydrolyzed by $4 \mathrm{~mL}$ of sulphuric acid (72 wt \%) and maintaining them for $30 \mathrm{~min}$ at $30{ }^{\circ} \mathrm{C}$. After, the sample was diluted by $86 \mathrm{~mL}$ of distilled water and it was incubated for one hour more at $120{ }^{\circ} \mathrm{C}$. Then, it was neutralized with calcium carbonate until $\mathrm{pH}=6-7$ and filtered using $0.2 \mu \mathrm{m}$ filters. Finally, it was analysed by HPLC as explained in the before section. In addition, the total organic carbon (TOC) was measured by Shimadzu equipment model TOC-VCSH. The carbon concentration of the standard solutions corresponds to $500 \mathrm{mg} \mathrm{C} / \mathrm{L}$. 


\section{Chapter 5}

\section{Comprehensive modelling}

\subsection{Fractionation process by hydrothermal processes at mild temperatures}

The fractionation takes place in solid phase where hemicellulose and cellulose start to break into oligomers of decreasing molecular weight. For both species, at a certain molecular weight, they became water-soluble and they are solubilized. From this point, the fractionation occurs as in solid phase as in liquid phase. In the latter, the solubilized oligomers hydrolyze, cleaving in smaller oligomers up to reach their respective monomers (sugars). Finally, these monomers, depending on temperature and residence time, can break into several degradation products, such as hydroxymethylfurfural, formic acid, lactic acid and others (Alvarez-Vasco \& Zhang, 2013; Feng et al., 2012; Yedro et al., 2015). Basically, the reactor behaves like a fixed bed extraction column (Figure 2-a). Therefore, solid is depleted from bottom to top and liquid is more concentrated at the outlet. This process continues up to all the removable biomass at the operating is recovered. Reached this point, a change in the operating temperature is performed, and the extraction process starts again. This new extraction could originate a thermal breaking process in the biomass sample, which means that some parts of the solid might be separated from the whole biomass and they might be fluidized outside of the fractionation column.

\subsection{Reaction pathway}

The proposed reaction mechanism is shown in Figure 3-a. As it was mentioned in section 1, the aim was to reproduce the experimental behavior of the reactor taking into account the main phenomena of the process, i.e. biomass cleaving and solubilization, biomass hydrolysis, changes in porosity and $\mathrm{pH}$ variations. To this end, for both, cellulose and hemicellulose, a population of several oligomers of decreasing length was used. In addition, deacetylation reactions were considered for hemicellulose family (Garrote et al., 2002; Parajó et al., 2004). Besides, a proton consumption reaction was introduced because it was observed some $\mathrm{pH}$ increments at the start of the operation. So, it was assumed that a certain amount of inorganic compounds with basic behavior was present in biomass. This value was initially fixed at $1 \%$ in order to provide enough substance to the neutralization but without disturbing the initial composition. On the other hand, two kinds of hemicellulose and cellulose were defined, one easily degradable and other hard to break (Charles et al., 2004; Klemm et al., 2005). For the former, this could be caused by 


\section{Chapter 5}

a structural reason, the fact that some hemicellulose fibers can be protected by cellulose and lignin, which reduces their breaking. Regarding cellulose, the reason would be that there is a certain fraction of cellulose which could not be crystalline. This subdivision means that each type of cellulose and hemicellulose has its own oligomer population (OP). The OP for both hemicelluloses was formed by 60 compounds each, 40 for the fibers which were not deacetylated and 20 for the fibers deacetylated. For cellulose, both populations also had 60 members. These OP were used to reproduce in a more real way the biomass cleaving into smaller and smaller species (Figure 3-b). In addition, it was assumed that cellulose fibers has 10,000 units and hemicellulose fibers 200 (Charles et al., 2004). In both cases, compounds from 1 to 20 units were simulated and the rest of the family was formed by oligomers with increments of 250 and 9 units respectively. So, for cellulose, its fiber would contain 10,000 units, the highest oligomer, 9,770 units and the following oligomer 9,520 units. For hemicellulose, its fiber would be formed by 200 units, the highest oligomer by 191 and the following by 182. In parallel, direct deacetylation reaction from both hemicelluloses, direct dimer and monomer (sugars C6) formation and direct oligomer and monomer (sugars C5) formation from hemicellulose easily degradable were also included. These two last reactions, were needed to reproduce the initial slow solubilization of biomass. Finally, hexoses (C6) formation from hemicellulose (Charles et al., 2004), sugar degradation, and polymerization reactions from degradation products (Kumar et al., 2010; Minowa et al., 1998) were considered too. 

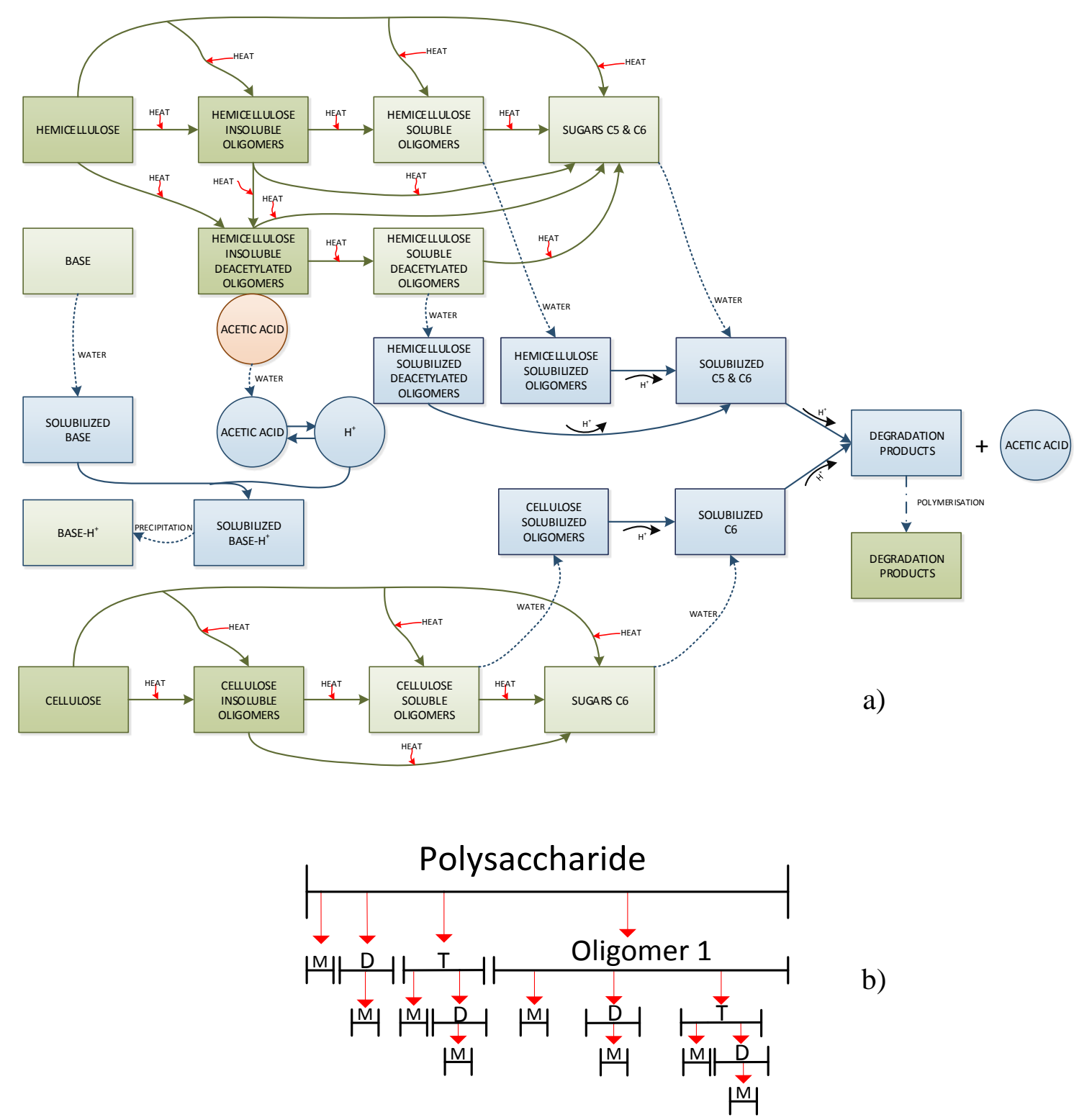

b)

Figure 3. Reaction pathway (a). Polysaccharide cleaving (b).M: monomer. D: dimer. T: trimer.

\subsection{Kinetic model}

In order to simplify the problem the following statements were assumed: (1) there are not temperature or concentration profiles within the solid along the reactor length, (2) the solid porosity only depends on the total concentration of the solid phase, (3) there are not significant diffusional effects in the solid or liquid phase, (4) lignin behaves as an inert, taking as negligible soluble lignin and (5) the reaction order for all the kinetics is 1 for the biomass compound. 


\section{Chapter 5}

\subsubsection{Mass balances}

\subsubsection{Solid phase}

The model was obtained applying a mass balance for each compound (Eq. ( 1 )). In order to introduce the effect of the porosity variations, the definition of the porosity (Eq. ( 2 )) was introduced in Eq. ( 1 ), obtaining Eq. ( 3 ).

$$
\begin{gathered}
\frac{d(1-\varepsilon) \cdot C_{S_{j}}}{d t}=r_{j}-k_{j} \cdot a \cdot\left(C_{L_{j}}^{*}-\bar{C}_{L_{j}}\right) \\
\mathcal{E}=1-\varphi \cdot C_{t} \\
\frac{d C_{S_{j}}}{d t}=\frac{1}{1-\varepsilon} \cdot\left[r_{j}-\varphi \cdot C_{S_{j}} \cdot \frac{d C_{t}}{d t}-k_{j} \cdot a \cdot\left(C_{L_{j}}^{*}-\bar{C}_{L_{j}}\right)\right]
\end{gathered}
$$

On the other hand, the mass balance to the insoluble lignin, considered as an inert compound, would be equation ( 4 ).

$$
\frac{d(1-\varepsilon) \cdot\left(C_{t}-\sum_{j=1}^{j=N} C_{S_{j}}\right)}{d t}=0
$$

\subsubsection{Liquid phase}

Developing a similar process to the solid phase, the mass balance for each liquid compound would be represented by Eq. ( 5 ).

$$
\frac{\partial C_{L_{j}}}{\partial t}=\frac{1}{\varepsilon} \cdot\left[r_{j}-\frac{u}{L} \cdot \frac{\partial C_{L_{j}}}{\partial z}-\varphi \cdot C_{L_{j}} \cdot \frac{d C_{t}}{d t}+k_{j} \cdot a \cdot\left(C_{L_{j}}^{*}-\bar{C}_{L_{j}}\right)\right]
$$

\subsubsection{Kinetics}

\subsubsection{Solid phase}

Solid kinetics were based on an autocatalytic model (Eq. ( 6 )) due to the fact that it has been successfully used by other authors (Capart et al., 2004) to reproduce the sudden changes in biomass at certain temperature. In addition, depending on the population this autocatalytic factor changes its definition. So, the auto catalytic factor $\left(F_{\text {auto }}\right)$ for the hemicellulose $\left(\mathrm{HC}_{1}\right)$ and cellulose $\left(\mathrm{C}_{1}\right)$ easily degradable is shown in Eq. ( 7 ). And for the hard hemicellulose $\left(\mathrm{HC}_{2}\right)$ and cellulose $\left(\mathrm{C}_{2}\right)$ is shown in Eq. ( 8 ).

$$
\begin{gathered}
r_{j}=-k_{d_{j}} \cdot C_{S_{j}} \cdot F_{\text {auto }} \cdot \sum_{i=1}^{N} \alpha_{i, j}+\sum_{i=1}^{N} \alpha_{j, i} \cdot F_{\text {auto }} \cdot k_{d_{i}} \cdot C_{S_{i}} \\
F_{\text {auto }}=\left(1-0.99 \cdot \frac{C_{H C_{1}}}{C_{t}}\right)^{\beta_{i, j}}
\end{gathered}
$$




\section{Chapter 5}

$$
F_{\text {auto }}=\left(1-0.99 \cdot \frac{m_{H C_{2}}}{m_{H C_{2_{o}}}}\right)^{\beta_{i, j}}
$$

Eq. ( 6 ) shows the overall kinetic for each solid compound, which is formed by two parts. The first represents the breaking of this compound into any product of lower molecular weight. Meanwhile, the second shows the formation of this compound from any component of higher molecular weight (Figure 3-b). Eq. ( 7 ) and ( 8 ) present two coefficients. The initial velocity factor, whose recommended value is 0.99 (Capart et al., $2004)$, and the acceleration factor $\left(\beta_{i, j}\right)$, which represents how fast the degradation is once the fractionation process has started. In the same way, the deacetylation kinetic were also defined by an autocatalytic expression for each compound of both hemicellulose populations (Eq. ( 9 ) and ( 10 ), respectively).

$$
\begin{gathered}
r_{d e a_{j}}=k_{d_{j}} \cdot C_{s_{j}} \cdot\left(1-0.99 \cdot \frac{C_{s_{j}}}{C_{t}}\right)^{\beta_{i, j}} \cdot\left(1-0.99 \cdot \frac{C_{s_{H C 1}}}{C_{t}}\right)^{\gamma_{i, j}} \\
r_{\text {deai }_{j}}=k_{d_{j}} \cdot C_{s_{j}} \cdot\left(1-0.99 \cdot \frac{m_{H C 1}}{m_{H C 1_{o}}}\right)^{\gamma_{i, j}}
\end{gathered}
$$

Finally, the direct deacetylation reactions from hemicellulose are shown in Eq. ( 11 ), ( 12 ) and ( 13 ), the oligomer and monomer production (C5) in Eq. ( 14 ) and the dimer and monomer formation (C6) in Eq. ( 15 ).

$$
\begin{gathered}
r_{\text {dead }}=k_{\text {dead }} \cdot C_{S_{H C 1}} \cdot\left(1-0.99 \cdot \frac{C_{S_{H C 1}}}{C_{t}}\right)^{\beta_{i, j}} \\
r_{\text {deadi }}=k_{\text {deadi }} \cdot C_{S_{H C 2}} \cdot\left(1-0.99 \cdot \frac{C_{S_{H C 1}}}{C_{t}}\right)^{\beta_{i, j}} \\
r_{\text {deadii }}=k_{\text {deadii }} \cdot C_{S_{H C 2}} \\
r_{c v}=k_{c v} \cdot C_{S_{H C 1}} \\
r_{\text {lent }}=k_{\text {lent }} \cdot C_{S_{H C 1}} \cdot\left(1-0.99 \cdot \frac{C_{S_{H C 1}}}{C_{t}}\right)^{\beta_{i, j}}
\end{gathered}
$$

\subsubsection{Liquid phase}

Liquid phase kinetics were defined in a similar way to solid phase kinetics but including the effect of the proton concentration, which works as a catalytic reaction (Eq. ( 16 )).

$$
r_{j}=-k_{L_{j}} \cdot C_{L_{j}} \cdot C_{H^{+}}^{n_{1}} \cdot \sum_{i=1}^{N} \alpha_{i, j}+\sum_{i=1}^{N} \alpha_{j, i} \cdot C_{H^{+}}^{n_{1}} \cdot k_{L_{i}} \cdot C_{L_{i}}
$$




\section{Chapter 5}

Moreover, in liquid phase there are sugar degradation, sugar deacetylation and repolymerization from degradation products reactions whose kinetics are shown by Eq. ( 17 ), ( 18 ) and ( 19 ) respectively. In Eq. ( 17 ) the addition of the sugar concentration was needed because they were calculated separately depending on their origin: $\mathrm{C} 1, \mathrm{C} 2$, $\mathrm{HC} 1, \mathrm{HC} 2$ or deacetylated fibers (from $\mathrm{HC} 1$ and $\mathrm{HC} 2$ ). In addition, the dissolution acetic acid equilibrium and the proton consumption reactions are arrayed in Eq. ( 20 ) and ( 21 ), respectively.

$$
\begin{gathered}
r_{\text {deg }}=\left(k_{\text {deg } 1} \cdot \sum_{i=1}^{i=2} C_{L_{\text {Sugar }-C 6}}^{n_{2}}+k_{\text {deg } 2} \cdot \sum_{i=1}^{i=4} C_{L_{\text {Sugar }-C 5}}^{n_{d}}\right) \\
\cdot C_{H^{+}}^{n_{2}} \cdot\left(1-0.99 \cdot \frac{C_{s_{H C 1}}}{C_{t}}\right)^{\beta_{i, j}} \\
r_{d e}=k_{\text {de }} \cdot C_{L_{\text {Sugar }}} \\
r_{\text {rep }}=k_{\text {rep }} \cdot C_{L_{D P}} \\
r_{\text {acet }}=k_{\text {direct }} \cdot C_{L_{\text {acet }}}-k_{\text {inverse }} \cdot C_{L_{\text {acet }}} \cdot C_{H^{+}} \\
r_{\text {prot }}=k_{\text {prot }} \cdot C_{L_{\text {base }}}
\end{gathered}
$$

\subsubsection{Kinetic constants}

Kinetic constants for biomass fractionation were defined to include the effect of the polymerization degree (molecular weight) of the reactive and the changes in biomass structure and water properties during the process. Therefore, all of them were defined by the Eq. ( 22 ). Where $\mathrm{R}$ is the ideal gas constant $\left(8.31 \mathrm{~J} \cdot \mathrm{mol}^{-1} \cdot \mathrm{K}^{-1}\right)$ and $\mathrm{T}$ the operating temperature $\left({ }^{\circ} \mathrm{C}\right)$.

$$
k_{d_{j}}=k_{L_{j}}=e^{A(T)-\frac{\left(E_{1}+E_{2} \cdot P D_{j}\right)}{R \cdot T}}
$$

The other kinetic constants were defined by the following expressions.

$$
\begin{gathered}
k_{\text {dead }}=e^{A-\frac{\left(E_{1}\right)}{R \cdot T}} \\
k_{\text {deadi }}=e^{A-\frac{\left(E_{1}+E_{2} \cdot P D_{H C}\right)}{R \cdot T}} \\
k_{\text {deadii }}=e^{A-\frac{\left(E_{1}\right)}{R \cdot T}} \\
k_{c v}=e^{A-\frac{\left(E_{1}+E_{2} \cdot P D_{H C}\right)}{R \cdot T}}
\end{gathered}
$$




$$
\begin{gathered}
k_{\text {lent }}=e^{A-\frac{\left(E_{1}+E_{2} \cdot P D_{H C}\right)}{R \cdot T}} \\
k_{\text {deg }}=e^{A-\frac{\left(E_{1}+E_{2} \cdot 1\right)}{R \cdot T}} \\
k_{\text {de }}=e^{A-\frac{\left(E_{1}+E_{2} \cdot 1\right)}{R \cdot T}} \\
k_{\text {rep }}=e^{A(T)-\frac{\left(E_{1}\right)}{R \cdot T}} \\
k_{\text {direct }}=e^{A-\frac{\left(E_{1}\right)}{R \cdot T}} \\
k_{\text {inverse }}=e^{A-\frac{\left(E_{1}\right)}{R \cdot T}} \\
k_{\text {prot }}=e^{A-\frac{\left(E_{1}\right)}{R \cdot T}}
\end{gathered}
$$

\subsubsection{Proton reaction order}

Proton concentration was considered in Eq. ( 16 ) and ( 17 ) because it is the main cause of biomass hydrolysis and it has a high effect in sugar degradation (Li et al., 2014). In order to obtain a theoretical value of its reaction order, the following process was done. As protons have a catalytic role, their effect in a general kinetic would be described by Eq. ( 34 ).

$$
K=e^{A-\frac{\left(E_{1}+f\left(C_{H^{+}}\right)\right)}{R \cdot T}}=e^{A} \cdot e^{-\frac{\left(E_{1}\right)}{R \cdot T}} \cdot e^{-\frac{f\left(C_{H^{+}}\right)}{R T}}
$$

If the function of the proton concentration would be logarithmic, $\left(e . g . f\left(C_{H^{+}}\right)=\right.$ $\ln \left(C_{H^{+}}\right)$), Eq. ( 34 ) could be rewritten into Eq. ( 35 ).

$$
K=e^{A-\frac{\left(E_{1}+f\left(C_{H^{+}}\right)\right)}{R \cdot T}}=e^{A} \cdot e^{-\frac{\left(E_{1}\right)}{R \cdot T}} \cdot C_{H^{+}}^{-\frac{1}{R \cdot T}}
$$

Therefore, the reaction order of the protons would depend directly proportional on temperature.

\subsubsection{Stoichiometric matrix}

All the equations were used in mass basis so their stoichiometric coefficients $\left(\alpha_{\mathrm{i}, \mathrm{j}}\right)$ were in mass basis too. They were defined in order to represent the cleavage of a polysaccharide fiber into any smaller compound (Figure 3-b). In addition, it was considered that any fiber mainly breaks into near oligomers (Eq. ( 36 )). This was supposed because during fractionation, biomass is slowly solved up to certain time is reached, when, suddenly its extraction rate is largely increased. On the other hand, for the deacetylation, it was assumed that if the PD is greater than 19 an average deacetylated 


\section{Chapter 5}

oligomer is produced and, if it is lower, one of the other 19 deacetylated oligomers is released. The breaking of these 20 deacetylated compounds was simulated as if their highest oligomer would have a PD of 20. This is done to include the fiber degradation during the deacetylation. Furthermore, the last assumption is supposed because the deacetylation would take place when biomass have been degraded into relative low PD oligomer.

$$
\alpha_{i, j}=\frac{\frac{\left(\frac{P D_{j}}{P D_{i}}\right)}{P D_{j}-P D_{i}}}{\sum_{i=1}^{N} \frac{\left(\frac{P D_{j}}{P D_{i}}\right)}{P D_{j}-P D_{i}}} ; \alpha_{1, j}=0
$$

For deacetylation it was considered that $1.0 \mathrm{~g}$ of reactive produces $0.3 \mathrm{~g}$ of acetic acid and $0.7 \mathrm{~g}$ of deacetylated oligomer. For the acetic acid equilibrium it was supposed that $1,0 \mathrm{~g}$ of acetic acid generates $0.017 \mathrm{~g}$ protons and $0.983 \mathrm{~g}$ of residue. For hexoses deacetylation, it was assumed that $0.33 \mathrm{~g}$ of acetic acid and $0.67 \mathrm{~g}$ of degradation products are produced. For direct formation of monomer from hemicellulose (C5), $1.0 \mathrm{~g}$ of hemicellulose generates $0.15 \mathrm{~g}$ of monomer and $0.85 \mathrm{~g}$ of oligomer of 191 units. And for direct formation of monomer from cellulose (C6), $1.0 \mathrm{~g}$ of cellulose generates $0.5 \mathrm{~g}$ of monomer and $0.5 \mathrm{~g}$ of dimer (cellobiose). The values of the coefficients above mentioned were obtained during the optimization. For proton consumption, it was assumed that 0.2 $\mathrm{g}$ react with $0.8 \mathrm{~g}$ of base material.

\subsubsection{Solubility}

Eq. ( 1 ), ( 3 ) and ( 5 ) show an equilibrium concentration in liquid phase $\left(\mathrm{C}_{\mathrm{Lj}}{ }^{*}\right)$ which is obtained by the product of an equilibrium constant $\left(\mathrm{H}_{\mathrm{j}}\right)$ and the concentration in the solid $\left(\mathrm{C}_{\mathrm{Lj}}{ }^{*}=\mathrm{H}_{\mathrm{j}} \cdot \mathrm{C}_{\mathrm{sj}}\right)$. This equilibrium constant represents the solubility of biomass and it should be a function of several variables: the polymerization degree, structure of the biopolymer, acetylation degree and some water properties (Kruse \& Dinjus, 2007; Miller-Chou \& Koenig, 2003; Teo et al., 2010). In order to include these aspects in its calculation, equation ( 37 ) was used.

$$
H_{j}=\frac{H_{o}(T) \cdot T}{1+e^{h_{p} \cdot\left(P D-P D_{h}\right)}}
$$

\subsection{Resolution}

The combination of Eq. ( 3 ) and ( 5 ) generates a set of partial differential equations (PDE) which need to be discretized to convert them into ordinary differential equations 
(ODE). The discretization was performed by the orthogonal colocation method on finite elements (Press et al., 2007). Once the discretization has been done, the set of ODE was solved by the Runge-Kutta's method with an $8^{\text {th }}$ convergence order. The fitting of the experimental data implied an optimization problem. Due to its complexity, it was previously initialized by solving it by hand, and then, optimized by the Nelder-MeadSimplex's method. Finally, the solution was reviewed in order to ensure the physical meaning of the parameters. The objective function was the minimization of the Absolute Average Deviation (A.A.D., Eq. ( 38 )) for TOC, acetic acid, sugar and degradation products concentration at the reactor output (given a higher weight to the TOC values).

$$
\text { A.A.D. }=\sum_{i=1}^{n} \frac{1}{n} \cdot\left|\frac{X_{\text {exp }}-X_{\text {sim }}}{X_{\text {exp }}}\right| \cdot 100
$$

\section{Results and Discussion}

\subsection{Effect of volumetric flow and temperature}

In this part, the role of the volumetric flow and the operating temperature is assessed. The former is shown in Figure 4-a by the TOC evolution at 3 different volumetric flows (11.5 $\mathrm{mL} / \mathrm{min}, 15.0, \mathrm{~mL} / \mathrm{min}$ and $27.0 \mathrm{~mL} / \mathrm{min})$ and at the same temperature range $\left(180^{\circ} \mathrm{C}-260\right.$ $\left.{ }^{\circ} \mathrm{C}\right)$. Apart from dilution, the following effects can be observed. At $180{ }^{\circ} \mathrm{C}$ the volumetric flow does not change the time of the maximum TOC value but it enhances the extraction, reducing the time of the final part of this stage. After the temperature change, flow again accelerates the process but it also modifies highly the maximum TOC time. This behavior could be explained by the fact that at $180^{\circ} \mathrm{C}$ biomass degrading would be slow enough to break into oligomers and not directly to dimers or monomers (with greater water solubility). So, an increment in the water velocity only affect to the end of this stage, when more soluble components would be produced. In contrast, at $260{ }^{\circ} \mathrm{C}$ biomass would be highly degraded, producing and enormous amount of soluble compounds and the volumetric flow would affect from the beginning. In addition, in this second stage a slow variation zone at the end of the process is observed because, at this time, biomass would be formed by very low soluble substances, such as deacetylated oligomers. Therefore, during the operation, 3 zones can be observed depending on the controlling resistance of the mass transfer. Two zones controlled by the solubility (for the first $10 \mathrm{~min}$ and at the end of the process) and other zone dominated by the external mass transfer (from $10 \mathrm{~min}$ 


\section{Chapter 5}

and until the temperature change). Being this latter, the zone where a change in volumetric flow can influence on the extraction. On the contrary, temperature affects to the whole process (Figure 4-b) which could be explained by the bigger formation of soluble compounds at higher temperatures.
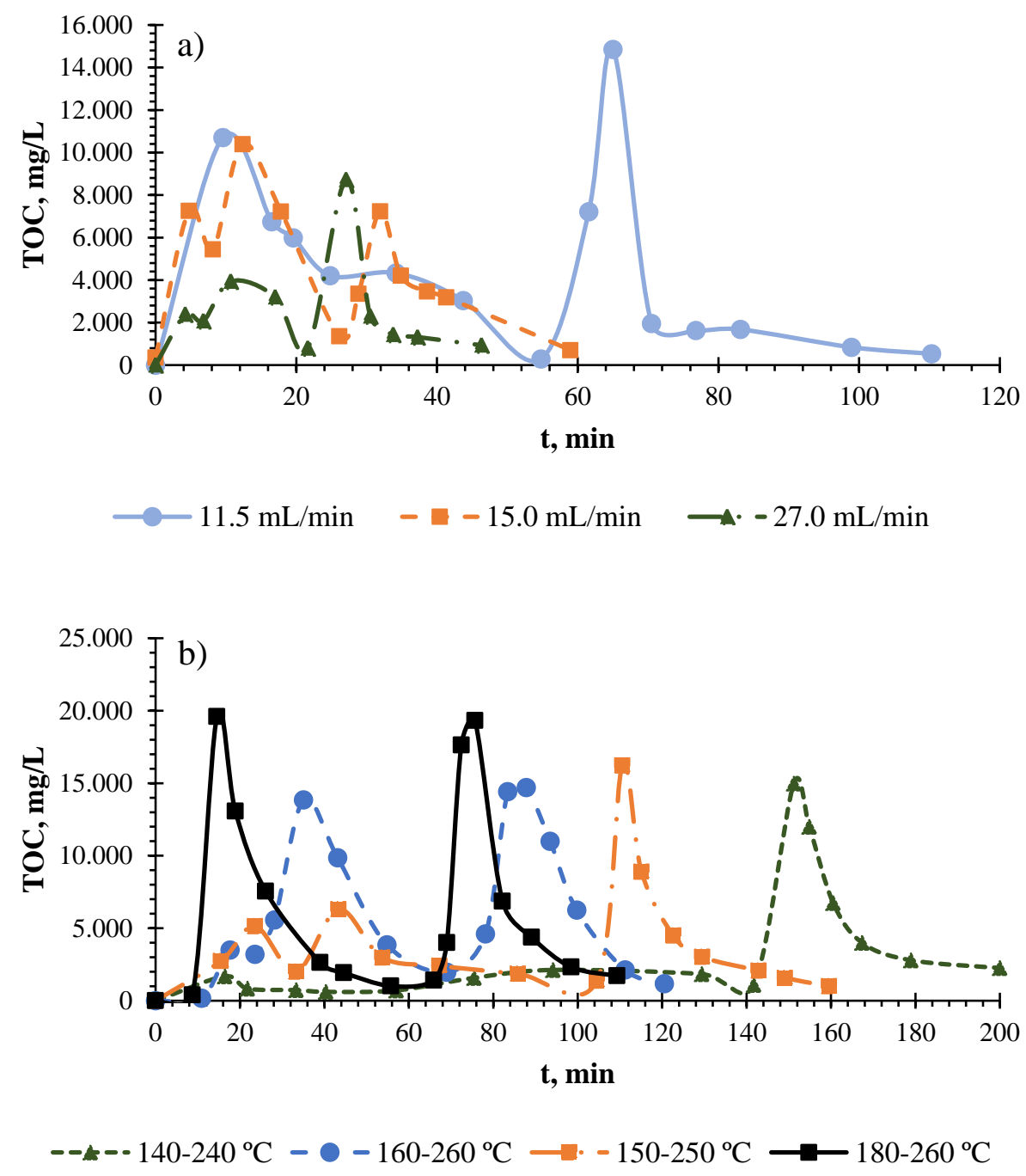

Figure 4. TOC evolution with volumetric flow (a) and temperature (b).

On the other hand, the final mass of the solid presented an interesting result (Table 2). It can be checked that the recovered mass after the operation (mReal) was always lower than the lignin content of the sample (mLignin), which at this conditions should behave as an inert. This discrepancy could be explained by a weakening of biomass structure due to the operation at two temperatures. So, after the second temperature change, some parts of biomass could be broken and fluidized. Finally, it can also be observed that temperature has an inverse proportional ratio to the final mass of the solid, which boosts the idea of a thermal breaking process. 


\section{Chapter 5}

Table 2. Final solid mass evolution.

\begin{tabular}{ccc}
\hline Experiment & $\begin{array}{c}\mathrm{m}_{\text {Real }}{ }^{1} \\
\mathrm{~g}\end{array}$ & $\begin{array}{c}\mathrm{m}_{\text {Lignin }}{ }^{2} \\
\mathrm{~g}\end{array}$ \\
\hline 1 & 0.2622 & 1.7227 \\
2 & 0.4659 & 1.7311 \\
3 & 0.8491 & 1.7508 \\
4 & 0.8733 & 1.7288 \\
6 & 0.4380 & 1.7525 \\
7 & 0.4601 & 1.7423 \\
8 & 0.8491 & 1.7616 \\
\hline
\end{tabular}

${ }^{1}$ Measured final solid mass. ${ }^{2}$ Lignin content of the sample and final mas expected after the operation.

\subsection{Fittings}

The validation of the model was performed by fitting the TOC for the experiments arrayed in Table 1. In addition, acetic acid concentration, sugars C5 and C6 concentration and degradation products concentration were simulated and checked with their experimental values for essays 2 to 5. For the latter, these fittings and simulations are shown in Figure 5. The obtained parameters for all of them are listed in Table 4.

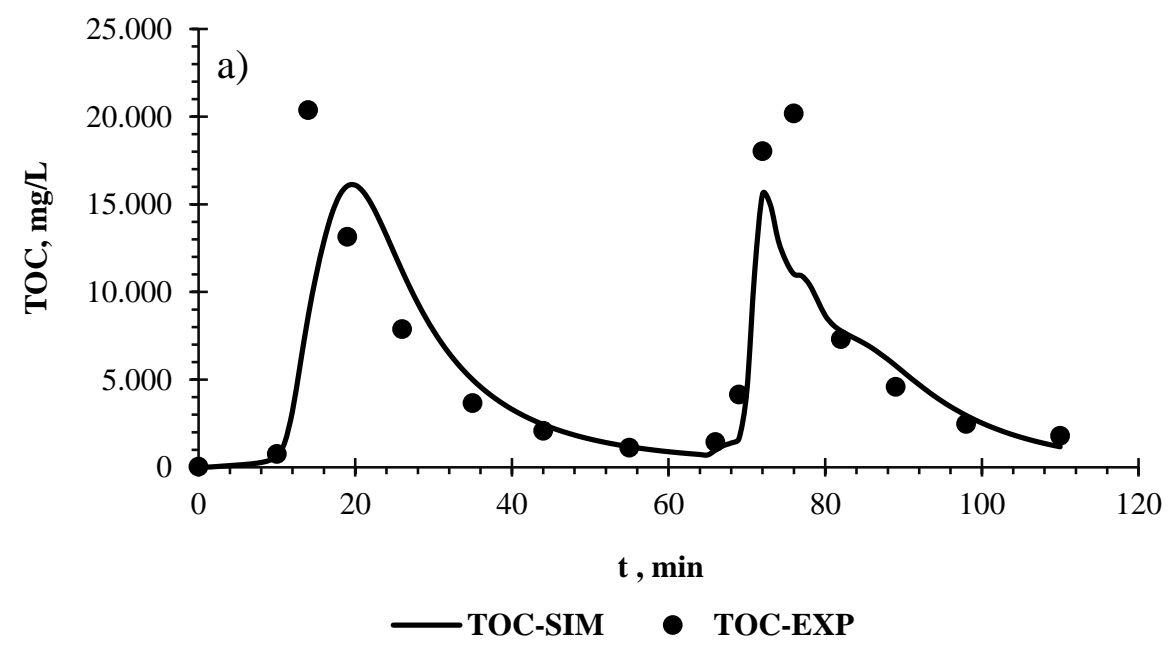




\section{Chapter 5}
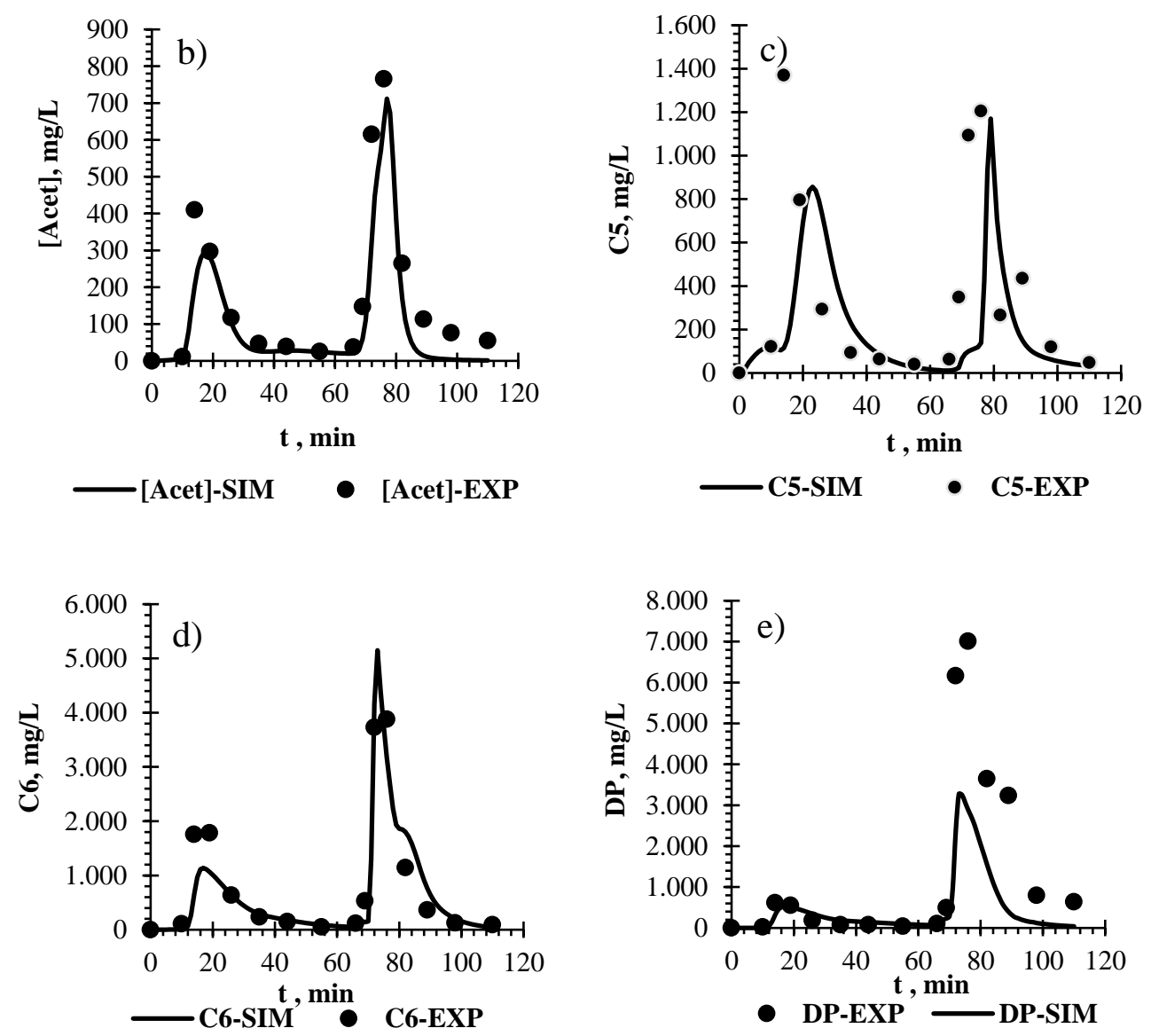

Figure 5. Adjustment of the experiment 5. TOC fitting (a), simulation of the concentration of acetic acid (b), sugars C5 (c), sugars C6 (d) and degradation products (e). TOC-EXP: measured TOC. TOC-SIM: simulated TOC. [Acet]EXP: measured acetic acid concentration. [Acet]-SIM: simulated acetic acid concentration. C5-EXP: measured C5 sugar concentration. C5-SIM: simulated C5 sugar concentration. C6-EXP: measured C6 sugar concentration. C6SIM: simulated C6 sugar concentration. DP-EXP: measured degradation products concentration. DP-SIM: simulated degradation products concentration.

Analyzing Figure 5-a it can be observed that the extraction was slow up to 10 min when the TOC suddenly increases. This also occurs in the acetic acid (Figure 5-b), C5 and C6 sugar concentration (Figure 5-c and Figure 5-d respectively) and degradation products concentration (Figure 5-e). This behavior could by caused by two reasons. The first could be that, up to this time, biomass degradation was not big enough to produce high soluble compounds (as it was mentioned in part 4.1). The second could be that, in parallel to oligomer formation, an acetic acid production (and releasing) takes places, enhancing the hydrolysis. After the maximum TOC value (14 min), a slower extraction was observed in all the profiles of Figure 5, which was attributed to a mass transfer limitation. In addition, 


\section{Chapter 5}

biomass would be more and more composed by low soluble products, such as deacetylated oligomers, $\mathrm{HC} 2$ and $\mathrm{C} 2$. This behavior continued up to the temperature change was performed (55 min), obtaining a similar behavior to the first step. Nevertheless, an initial slow period is not present due to the fact that at $260{ }^{\circ} \mathrm{C}$ biomass degradation is so high that soluble compounds are directly produced. From this adjustment, it can be concluded that the model is suitable to simulate a biomass fractionation process. The same conclusion can be obtained from the value of the A.A.D. for each assay (Table 3). Which were relatively low taking into account the complexity of the reaction process, the little amount of initial raw material, the diversity of biomass and the dilution of the outlet stream. This latter would increase the average deviation from $33 \%$ at low flow (experiments 1 to 5 ) up to $58 \%$ at high flow (experiments 6 to 8). Focusing in the calculated values, it can be seen that the lowest deviations were in TOC fittings (42.62\%). The experimental data of sugar and degradation product of experiment 1 were not considered because their values showed discrepancy with the tendency fixed by experiments 2 to 5 . In the case of experiments 6 and 7, only TOC was considered due to the high dilution of these samples.

Table 3. A.A.D. of the fittings.

\begin{tabular}{cccccc}
\hline \multirow{2}{*}{ Experiment } & \multicolumn{5}{c}{ A.A.D. } \\
& TOC & {$[\text { Acetic Acid }]^{1}$} & C5 ${ }^{2}$ & C6 $^{3}$ & DP $^{4}$ \\
\hline 1 & 51.15 & 61.06 & $*$ & $*$ & $*$ \\
2 & 24.55 & 49.51 & 54.75 & 65.45 & 48.56 \\
3 & 34.61 & 56.26 & 60.58 & 60.79 & 77.02 \\
4 & 25.36 & 47.11 & 51.78 & 57.87 & 66.24 \\
5 & 30.15 & 45.02 & 73.56 & 49.56 & 75.35 \\
6 & 63.36 & $*$ & $*$ & $*$ & $*$ \\
7 & 53.29 & $*$ & $*$ & $*$ & $*$ \\
8 & 58.47 & $*$ & $*$ & $*$ & $*$ \\
\hline Average & 42.62 & 51.79 & 60.17 & 58.42 & 66.79 \\
\hline Acetic acid concentration. ${ }^{2}$ Sugars C5 concentration. ${ }^{3}$ Sugars C6 \\
concentration. ${ }^{4}$ Degradation & products & concentration. ${ }^{*}$ Experimental \\
data which were not considered.
\end{tabular}




\section{Chapter 5}

\subsubsection{Fitted parameters}

In this section an analysis of the parameters showed in Table 4 is done. It is interesting the fact that obtained kinetic parameters $\left(A, \beta_{i, j}\right.$ and $\left.\gamma_{i, j}\right)$ show changes around $150{ }^{\circ} \mathrm{C}$ and $240{ }^{\circ} \mathrm{C}$. Temperatures that represent the start of the fast degradation of hemicellulose and cellulose, respectively (Kumar et al., 2010; Minowa et al., 1998; Pronyk \& Mazza, 2010; Rissanen et al., 2014). Therefore, the tendency calculated for these variables agrees with the data reported by other authors, showing that the model is able to reproduce the process with physical meaning. Regarding the equilibrium constants $\left(H_{j}\right)$, it was observed that for $\mathrm{C} 1$ and $\mathrm{C} 2$ the opposite behavior was obtained. The first increased its value with temperature up to $240{ }^{\circ} \mathrm{C}$ and the second is constant until $180{ }^{\circ} \mathrm{C}$, where in starts to grow. This behavior could be explained by the fact that $\mathrm{C} 1$ should be more soluble than $\mathrm{C} 2$ due to its lack of crystallinity. So, the former would increase its water solubility up to it would be totally soluble. The later, by the contrary, would have a low (and constant) solubility up to certain temperature when it would start to solve more and more due to the change in water properties. Hemicelluloses showed the same tendency as $\mathrm{C} 1$ but with smoother changes because of they are more soluble. It is also interesting that the polymerization constant decreases at $240^{\circ} \mathrm{C}$, which would be originated because of the fact that the bonds breaking would be bigger than the repolymerization at high temperatures. Finally, it is remarkable that the reaction order for proton increases with temperature, confirming the theoretical development showed in part 3.3.2.2.

\subsubsection{Acceleration factors. Effect of temperature and volumetric} flow.

Temperature and flow influenced on the acceleration factors in an opposite way, increasing and decreasing them respectively. Regarding temperature, the behavior could be explained because of a higher temperature means more biomass degradation, more oligomer production and, due to this, a more abrupt process. In contrast, a greater flow would reduce the residence time of the products, enhancing the extraction (if temperature is high enough). So, oligomer would have less time to degrade and the fractionation would be smoother. 


\section{Chapter 5}

\subsubsection{Hemicellulose and cellulose composition.}

In the point 3.2, it was assumed that two types of hemicelluloses (HC1 and HC2) and cellulose ( $\mathrm{C} 1$ and $\mathrm{C} 2)$ can be present in biomass. Therefore, their initial composition constituted other 2 parameters to fit. The calculated value for $\mathrm{HC} 1$ and $\mathrm{C} 1$ were $75 \%$ and $30 \%$ of the total hemicellulose and cellulose content, respectively. This result agrees with the expected behavior because, in general, cellulose is more difficult to extract than hemicellulose. So, $\mathrm{C} 2$ and $\mathrm{HC} 1$ would be the main components in biomass. In addition, these values also agree with literature (Charles et al., 2004; Klemm et al., 2005; Parajó et al., 2004). For HC1 has been reported that its value is between $65 \%$ and $90 \%$ of the total hemicellulose and for $\mathrm{C} 2$ around $65 \%$.

\subsection{Simulated behavior}

Finally, an overall simulation of the fractionation was performed (Figure 6 and Table 5). Figure 6-a shows the evolution of the solid composition during the process, which agrees with the experimental data showed in 4.2.1. During the first stage, hemicellulose is mainly extracted and only a few part of cellulose (C1) is also recovered. The main part of cellulose (C2) and a few amount of hemicellulose (HC1) remain in solid up to the temperature change is done, being solubilized. Finally, the solid is formed by residual cellulose (as cellobiose), deacetylated oligomers and the repolymerization products. Solid phase composition is also represented in Figure 6-c and Figure 6-d by population $\mathrm{C} 2$ and $\mathrm{HC} 1$ evolution respectively. It is remarkable the result for $\mathrm{HC} 1$ because up to 22 min of operation the main products are oligomers. So, this simulation agrees with the explanation given in part 4.1 about the temperature and water flow effect. In addition, these simulations are interesting because they reproduce a real composition of biomass, which could be a mandatory factor to decide when stop the process. On the other hand, liquid behavior is shown in Figure 6-b. At the beginning of the process (until $10 \mathrm{~min}$ ), mainly sugars would be recovered because biomass has not been fractionated yet. Once this time have been reached, biomass would produce soluble oligomers and they would be the main component in the liquid phase. This tendency continuous up to around 60 min, when biomass would be exhausted, and the concentration of oligomers starts to decrease. Moreover, at this time, the temperature change is performed and many degradation products and sugar are produced, increasing their concentrations quickly. At the end of the process, the oligomers would be again the main component in the liquid 


\section{Chapter 5}

because only cellobiose, deacetylated oligomers and repolymerization products would remain in the solid.
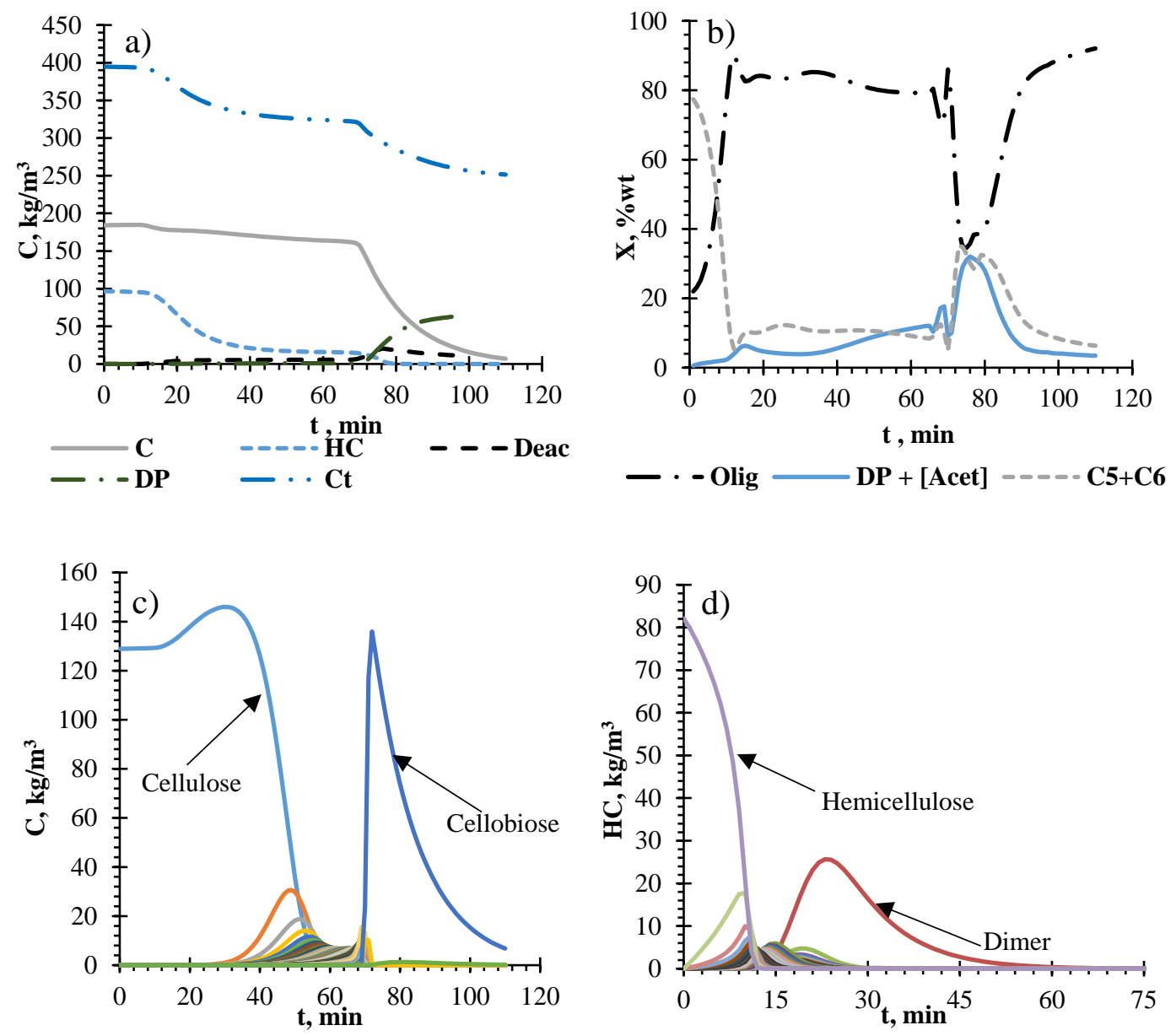

Figure 6. Overall simulation of the process. (a) Evolution of solid cellulose and hemicellulose. (b) Liquid oligomer concentration. (c) Solid C2 population evolution. (d) Solid HC1 population evolution. HC: total solid hemicellulose content. C: total solid cellulose content. REP: polymerization product in the solid. DO: deacetylated product in the solid. Ct: total solid concentration. Olig: Liquid oligomer content . DP + [Acet]: addition of the amount of degradation product and acetic acid in the liquid. C5+C6: total sugar amount in the liquid.

Finally, the amount of extracted biomass was calculated and compared with the experimental data (Table 5). It can be seen that, generally, the experimental value is bigger than the simulated due to the fluidization process explained in 3.1. Thus, this discrepancy could be another reason for the deviation between the simulated and experimental behavior. It is also remarkable that for experiments 7 and 8 the data are lower than the simulated. Which could be caused by the dilution of the sample in these experiments. 


\section{Chapter 5}

Table 5. Simulation of the extracted biomass.

\begin{tabular}{cccc}
\hline Experiment & $\mathrm{m}_{\text {Real }}{ }^{1}$ & $\mathrm{~m}$ Simulated $^{2}$ & $\mathrm{~m}_{\text {Theorical }}{ }^{3}$ \\
& $\mathrm{~g}$ & $\mathrm{~g}$ & $\mathrm{~g}$ \\
\hline 1 & 4.2720 & 3.5948 & 4.3002 \\
2 & 4.1968 & 3.6212 & 4.3211 \\
3 & 4.1796 & 3.8357 & 4.3704 \\
4 & 3.5992 & 3.9716 & 4.3154 \\
5 & 3.8850 & 3.6408 & 4.3745 \\
6 & 4.6349 & 4.0318 & 4.3491 \\
7 & 3.7172 & 4.0280 & 4.3973 \\
8 & 3.4134 & 4.0061 & 4.3419
\end{tabular}

${ }^{1}$ Extracted biomass during the process. ${ }^{2}$ Simulated value of the extracted biomass. ${ }^{3}$ Total amount of cellulose and hemicellulose in the solid. 
Table 4.1

Table 4. Fitted parameters for solid (4.1) and liquid phase (4.2).

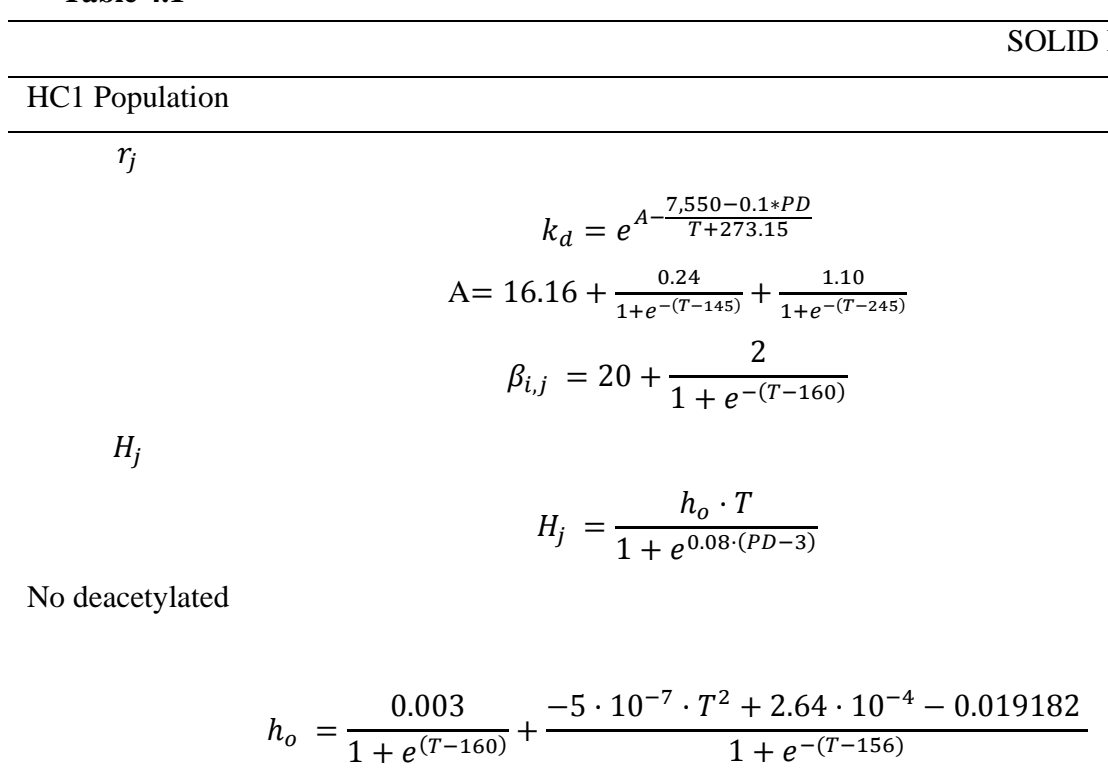

Deacetylated

$$
h_{o}=0.005
$$

$r_{d e a_{j}}$

$$
\begin{gathered}
k_{d}=e^{12.0-\frac{7,550-0.1 * P D}{T+273.15}} \\
\beta_{i, j}=200-\frac{80}{1+e^{-(T-155)}} \\
\gamma_{i, j}=\frac{15}{1+e^{-(T-155)}}
\end{gathered}
$$

$r_{\text {dead }}$
HC2 Population

$$
\begin{gathered}
k_{d}=e^{A-\frac{7,550-0.1 * P D}{T+273.15}} \\
\mathrm{~A}=12+\frac{4}{1+e^{-(T-245)}} \\
\beta_{i, j}=\frac{1}{1+e^{-(T-165)}}+\frac{30}{1+e^{-(T-245)}}
\end{gathered}
$$

$H_{j}$

$$
H_{j}=\frac{h_{o} \cdot T}{1+e^{0.08 \cdot(P D-3)}}
$$

No deacetylated

$$
h_{o}=\frac{0.003}{1+e^{(T-160)}}+\frac{-5 \cdot 10^{-7} \cdot T^{2}+2.64 \cdot 10^{-4}-0.019182}{1+e^{-(T-156)}}
$$

Deacetylated

$$
h_{o}=0.005
$$

$r_{d e a_{j}}$

$$
\begin{gathered}
k_{d}=e^{12.5-\frac{7,550-0.1 * P D}{T+273.15}} \\
\gamma_{i, j}=5
\end{gathered}
$$

$r_{\text {deadi }}$

$$
k_{\text {deadi }}=e^{7.5-\frac{6,392}{T+273.15}}
$$




$$
\begin{aligned}
& k_{\text {dead }}=e^{12.0-\frac{7,550-0.1 * 200}{T+273.15}} \\
& \beta_{i, j}=50+\frac{10}{1+e^{-(T-155)}}
\end{aligned}
$$

$r_{c v}$

$$
k_{c v}=e^{11.2-\frac{7,550-0.1 * 200}{T+273.15}}
$$

$r_{\text {lent }}$

$$
k_{\text {lent }}=e^{12.0-\frac{8,000-0.1 * 200}{T+273.15}}
$$$$
\beta_{i, j}=7+\frac{1}{1+e^{-(T-155)}}
$$

\section{C1 Population}

$r_{j}$

$k_{d}=e^{A-\frac{8,000-0.1 * P D}{T+273.15}}$
$A=18.5$
$\beta_{i, j}=\frac{15}{1+e^{-(T-160)}}$
$H_{j}=\frac{h_{o} \cdot T}{1+e^{0.08 \cdot(P D-1)}}$
$H_{j}=\frac{h_{o} \cdot T}{1+e^{(T-180)}+\frac{9 \cdot 10^{-5}-0.0152}{1+e^{-(T-180)}}}$
$h_{o}=\frac{0.0011 \cdot T-0,0144}{1+e^{(T-250)}}+\frac{0.012}{1+e^{-(T-250.2)}}$

$$
\beta_{i, j}=15+\frac{55}{1+e^{-(T-155)}}
$$

$r_{\text {deadii }}$

\begin{tabular}{c}
$k_{\text {deadii }}=e^{1-\frac{6,392}{T+273.15}}$ \\
\hline C2 Population \\
$k_{d}=e^{A-\frac{8,000-0.1 * P D}{T+273.15}}$ \\
$A=17.50+\frac{0.5}{1+e^{-(T-245)}}$ \\
$\beta_{i, j}=4$
\end{tabular}




\section{Table 4.2}

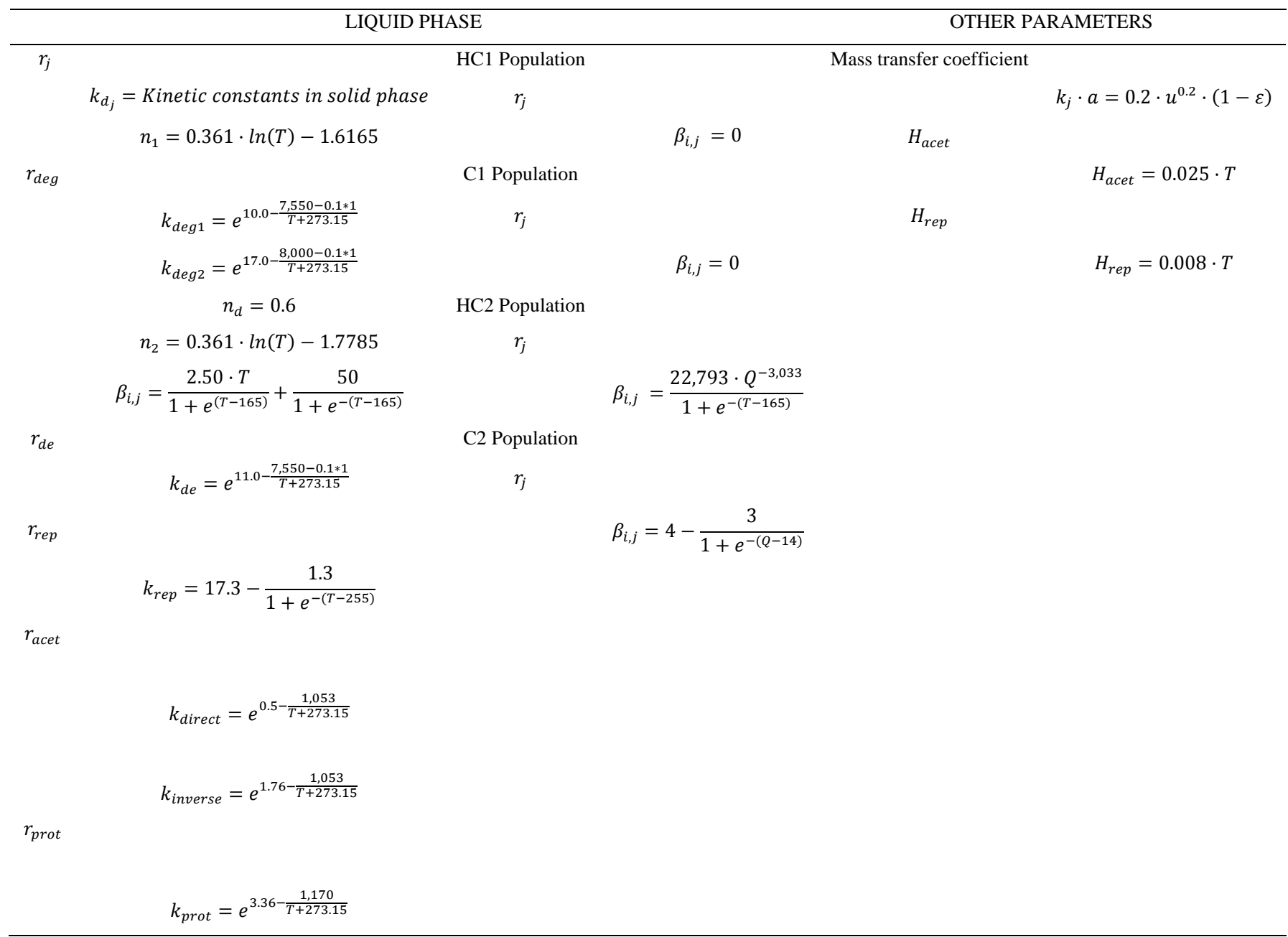




\section{Chapter 5}

\subsection{Model limitations and other biomasses}

From the discussions showed in section 4.2 and 4.3, it can be concluded that the model is able to reproduce the holm oak fractionation in a packed bed reactor at subcritical conditions. However, in order to apply this model to other biomass samples the following statements should be considered:

- The reaction pathway was developed for woody biomass, as hardwood as softwood. Thus, to adjust any other woody species only changes in the parameters or/and in the initial biopolymer length would be required. For other hardwood woods, the changes in the parameters would be required because the fractionation also depends on the structure and chemical properties of biomass.

- Extractives and soluble lignin were assumed as negligible substances. Therefore, to reproduce the behavior of any biomass with a great amount of any of them, such as grape seeds, new mass balances for these compounds should be added.

- The reaction pathway was done assuming that the biomass sample would be composed of cellulose, hemicellulose and lignin. However, there are several species that present other polysaccharides, like starch, which could not be studied with the presented model.

- Lignin as an inert. Lignin does not start its degradation up to $300{ }^{\circ} \mathrm{C}$, however it protects cellulose and hemicellulose against degradation. Therefore, changes in lignin composition would require a new set of parameters to reproduce the biomass breaking.

\section{Conclusions}

A kinetic model for hydrothermal fractionation of holm oak was developed and validated in this work. This model could reproduce the experimental data considering all the physical phenomena observed, like porosity variations, and the molecular weight distributions. Moreover, a novel reaction pathway based on 4 different populations of oligomers was introduced. These populations were defined according to their origin: hard cellulose, hard hemicellulose, weak cellulose or weak hemicellulose. Finally, the temperature and flow effect was assessed, founding that temperature is the main influencing parameter. The water flow affected to the process only if temperature was high enough to degrade biomass. 


\section{Chapter 5}

\section{Nomenclature}

Greek letters

$\alpha_{i, j}$ or $\alpha_{j, i}$ : Stoichiometric coefficient of the compound “ $\mathrm{j}$ ” for the reaction " $i$ ”, mg.

$\beta_{i, j}$ or $\gamma_{i, j}$ : Acceleration factor for the compound " $\mathrm{j}$ " in the reaction " $\mathrm{i}$ ", dimensionless.

$\mathcal{E}$ and $\varphi$ : Porosity of the bed and the Relation factor between it and $\mathrm{C}_{\mathrm{t}}$, dimensionless.

Symbols

$\mathrm{A}(T)$ or A: Napierian logarithm of the kinetic prexponetial factor, dimensionless.

$\mathrm{C}_{\mathrm{H}^{+}}$: Proton concentration in liquid phase, $\mathrm{mg} / \mathrm{min} \cdot \mathrm{L}$.

$\mathrm{C}_{\mathrm{L}_{\text {acet }}{ }^{-}}$: Concentration of the acetate, $\mathrm{mg} / \mathrm{L}$.

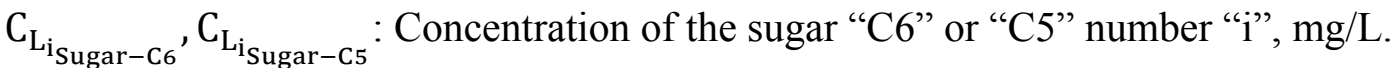

$\mathrm{C}_{\mathrm{L}_{\mathrm{j}}}, \mathrm{C}_{\mathrm{L}_{\mathrm{i}}}:$ : Concentration of the compound " $\mathrm{j}$ " or "ij" in the liquid phase, $\mathrm{mg} / \mathrm{L}$.

$\mathrm{C}_{\mathrm{L}_{\mathrm{j}}}^{*}$ : Equilibrium concentration of the compound " $\mathrm{j}$ " in liquid phase, $\mathrm{mg} / \mathrm{L}$.

$\overline{\mathrm{C}}_{\mathrm{L}_{\mathrm{j}}}$ : Average concentration of the compound " $\mathrm{j}$ " along the reactor in liquid phase, $\mathrm{mg} / \mathrm{L}$.

$\mathrm{C}_{\mathrm{L}_{\text {sugar }}}:$ Total sugar concentration in liquid phase, $\mathrm{mg} / \mathrm{L}$.

$\mathrm{C}_{S_{j}}, \mathrm{C}_{S_{\mathrm{i}}}$ : Concentration of the compound " $\mathrm{j}$ " or " $\mathrm{i}$ " in the solid phase, $\mathrm{mg} / \mathrm{L}$.

$\mathrm{C}_{\mathrm{t}}$ : Total concentration in the solid, $\mathrm{mg} / \mathrm{L}$.

$E_{1}, E_{2}$ : Base activation energy and Correction factor of the base activation energy depending on the molecular weight, $\mathrm{J} / \mathrm{mol}$.

$\mathrm{F}_{\text {auto }}$ : Auto catalytic factor for the solid kinetics, dimensionless.

$\mathrm{H}_{\mathrm{j}}$ : Equilibrium constant between the solid and the liquid, dimensionless.

$\mathrm{H}_{\mathrm{o}}(\mathrm{T})$ : Solubility constant, ${ }^{\circ} \mathrm{C}^{-1}$.

$\mathrm{k}_{\mathrm{d}_{\mathrm{j}}}$ : Kinetic constant of the compound “ $\mathrm{j}$ ", $\mathrm{mg}^{-1} \cdot \mathrm{min}^{-1}$.

$\mathrm{k}_{\mathrm{j}} \cdot \mathrm{a}$ : Mass transfer coefficient multiplied by the specific exchange area, $\min ^{-1}$. 


\section{Chapter 5}

$\mathrm{k}_{\mathrm{L}_{\mathrm{j}}}$ : Kinetic constant for compound " $\mathrm{j}$ ” in liquid phase, $\mathrm{L}^{\mathrm{n}_{1}} \cdot \mathrm{mg}^{-1-\mathrm{n}_{1}} \cdot \mathrm{min}^{-1}$.

L: Length of the reactor, m. z: Dimensionless length of the reactor, dimensionless.

$\mathrm{m}_{\mathrm{i}}, \mathrm{m}_{\mathrm{i}_{\mathrm{o}}}$ : Solid mass and its initial value of the compound "i $\mathrm{i}$ ", $\mathrm{mg}$.

n: Total number of experiments, dimensionless.

$\mathrm{n}_{1}, \mathrm{n}_{2}$ : Reaction order for proton concentration in hydrolysis and sugar degradation, dimensionless.

$\mathrm{N}$ : Number of compounds, dimensionless.

$\mathrm{PD}_{\mathrm{j}}$ : Polymerization degree of compound “j”, dimensionless.

$\mathrm{PD}_{\mathrm{h}}$ : First correction factor of the $\mathrm{PD}_{\mathrm{j}}$ for solubility calculations, dimensionless.

$\mathrm{r}_{\mathrm{cv}}$ : C5 formation from $\mathrm{HC} 1$ reaction rate, $\mathrm{mg} / \mathrm{min} \cdot \mathrm{L} . \mathrm{k}_{\mathrm{cv}}$ : Kinetic constant of $\mathrm{r}_{\mathrm{cv}}, \mathrm{mg}^{-}$ $1 \cdot \min ^{-1}$.

$\mathrm{r}_{\text {acet }}$ : Reaction rate for the acetic acid dissociation, $\mathrm{mg} / \mathrm{min} \cdot \mathrm{L} . \mathrm{k}_{\mathrm{direct}}$, Kinetic constant of acetic acid dissolution, $\mathrm{mg}^{-1} \cdot \mathrm{min}^{-1}$. $\mathrm{k}_{\text {inverse }}$ : Kinetic constant of acetic acid recombination, $\mathrm{L} \cdot \mathrm{mg}^{-2} \cdot \mathrm{min}^{-1}$

$r_{\text {dea }_{j}}$ : Deacetylation reaction rate for compound “j”, $\mathrm{mg} / \mathrm{min} \cdot \mathrm{L}$.

$\mathrm{r}_{\text {dead }}$ : Reaction rate of the direct deacetylation of $\mathrm{HC} 1, \mathrm{mg} / \mathrm{min} \cdot \mathrm{L} . \mathrm{k}_{\mathrm{dead}}$ : Kinetic constant of $r_{\text {dead }}, \mathrm{mg}^{-1} \cdot \mathrm{min}^{-1}$.

$r_{\text {deadi }}$ : First reaction rate of the direct deacetylation of $\mathrm{HC} 2, \mathrm{mg} / \mathrm{min} \cdot \mathrm{L} . \mathrm{k}_{\mathrm{deadi}}$ : Kinetic constant of $r_{\text {deadi }}, \mathrm{mg}^{-1} \cdot \mathrm{min}^{-1}$.

$\mathrm{r}_{\text {deadii }}$ : Second reaction rate of the direct deacetylation of $\mathrm{HC} 2, \mathrm{mg} / \mathrm{min} \cdot \mathrm{L} . \mathrm{k}_{\mathrm{deadii}}$ : Kinetic constant of $r_{\text {deadii }}, \mathrm{mg}^{-1} \cdot \min ^{-1}$.

$\mathrm{r}_{\text {lent }}$ : C6 formation from $\mathrm{HC} 1$ reaction rate, $\mathrm{mg} / \mathrm{min} \cdot \mathrm{L} . \mathrm{k}_{\text {lent }}$ : Kinetic constant of $\mathrm{r}_{\text {lent }}$, $\mathrm{mg}^{-1} \cdot \min ^{-1}$.

$\mathrm{r}_{\mathrm{de}}$ : Reaction rate for sugar deacetylation, $\mathrm{mg} / \mathrm{min} \cdot \mathrm{L} . \mathrm{k}_{\mathrm{de}}$ : Kinetic constant of $\mathrm{r}_{\mathrm{de}}, \mathrm{mg}^{-}$ $1 \cdot \min ^{-1}$. 


\section{Chapter 5}

$\mathrm{r}_{\mathrm{deg}}$ : Reaction rate for sugar degradation, $\mathrm{mg} / \mathrm{min} \cdot \mathrm{L} . \mathrm{k}_{\mathrm{deg} 1}, \mathrm{k}_{\mathrm{deg} 2}::$ Kinetic constant for C6 and C5 degradation, $\mathrm{L}^{\mathrm{n}_{2}} \cdot \mathrm{mg}^{-1-\mathrm{n}_{2}} \cdot \mathrm{min}^{-1}$.

$r_{j}$ : Reaction rate of the compound "j", $\mathrm{mg} / \mathrm{min} \cdot \mathrm{L}$.

$r_{\text {rep }}$ : Reaction rate for the polymerization, $\mathrm{mg} / \mathrm{min} \cdot \mathrm{L} . \mathrm{k}_{\mathrm{rep}}$ : Kinetic constant of $\mathrm{r}_{\mathrm{rep}}$, $\mathrm{mg}^{-1} \cdot \min ^{-1}$.

$\mathrm{r}_{\text {prot }}$ : Proton consumption reaction rate, $\mathrm{mg} / \mathrm{min} \cdot \mathrm{L}$. $\mathrm{k}_{\text {prot }}$ : Kinetic constant of $\mathrm{r}_{\text {prot }}, \mathrm{mg}^{-}$ $1 \cdot \min ^{-1}$.

t: Operating time, min.

$\mathrm{u}$ : Liquid velocity in the reactor, $\mathrm{m} / \mathrm{min}$.

$\mathrm{X}_{\mathrm{exp}}, \mathrm{X}_{\text {sim }}$ : Experimental and simulated value of the fitted variable.

\section{Acknowledgements}

The authors acknowledge the Spanish Economy and Competitiveness Ministry, Project Reference: ENE2012-33613 for funding. Álvaro Cabeza would like to thank to the Spanish Ministry of Education Culture and Sports, training program of university professors (reference FPU2013/01516) for the research training contract.

\section{References}

Alvarez-Vasco, C., Zhang, X. 2013. Alkaline hydrogen peroxide pretreatment of softwood: Hemicellulose degradation pathways. Bioresource Technology, 150, 321-327.

Bobleter, O. 1994. Hydrothermal degradation of polymers derived from plants. Progress in Polymer Science (Oxford), 19(5), 797-841.

Capart, R., Khezami, L., Burnham, A.K. 2004. Assessment of various kinetic models for the pyrolysis of a microgranular cellulose. Thermochimica Acta, 417(1), 79-89.

Carrier, M., Loppinet-Serani, A., Denux, D., Lasnier, J.-M., Ham-Pichavant, F., Cansell, F., Aymonier, C. 2011. Thermogravimetric analysis as a new method to determine the lignocellulosic composition of biomass. Biomass and Bioenergy, 35(1), 298307.

Charles, E.W., Stephen, R.D., Michael, E.H., John, W.B., Catherine, E.S., Liisa, V. 2004. Hydrolysis of Cellulose and Hemicellulose. in: Polysaccharides, CRC Press. 


\section{Chapter 5}

Feng, Y., Qi, X., Jian, H.L., Sun, R.C., Jiang, J.X. 2012. Effect of inhibitors on enzymatic hydrolysis and simultaneous saccharification fermentation for lactic acid production from steam explosion pretreated lespedeza stalks. BioResources, 7(3), $3755-3766$.

Garrote, G., Domínguez, H., Parajó, J.C. 2002. Interpretation of deacetylation and hemicellulose hydrolysis during hydrothermal treatments on the basis of the severity factor. Process Biochemistry, 37(10), 1067-1073.

Haghighat Khajavi, S., Kimura, Y., Oomori, T., Matsuno, R., Adachi, S. 2005. Kinetics on sucrose decomposition in subcritical water. LWT - Food Science and Technology, 38(3), 297-302.

Klemm, D., Schmauder, H.-P., Heinze, T. 2005. Cellulose. in: Biopolymers Online, Wiley-VCH Verlag GmbH \& Co. KGaA.

Kruse, A., Dinjus, E. 2007. Hot compressed water as reaction medium and reactant: Properties and synthesis reactions. The Journal of Supercritical Fluids, 39(3), 362380.

Kumar, S., Gupta, R., Lee, Y.Y., Gupta, R.B. 2010. Cellulose pretreatment in subcritical water: Effect of temperature on molecular structure and enzymatic reactivity. Bioresource Technology, 101(4), 1337-1347.

Li, H.-Q., Jiang, W., Jia, J.-X., Xu, J. 2014. pH pre-corrected liquid hot water pretreatment on corn stover with high hemicellulose recovery and low inhibitors formation. Bioresource Technology, 153(0), 292-299.

Lin, R., Cheng, J., Ding, L., Song, W., Qi, F., Zhou, J., Cen, K. 2015. Subcritical water hydrolysis of rice straw for reducing sugar production with focus on degradation by-products and kinetic analysis. Bioresource Technology, 186(0), 8-14.

Miller-Chou, B.A., Koenig, J.L. 2003. A review of polymer dissolution. Progress in Polymer Science, 28(8), 1223-1270.

Minowa, T., Zhen, F., Ogi, T. 1998. Cellulose decomposition in hot-compressed water with alkali or nickel catalyst. The Journal of Supercritical Fluids, 13(1-3), 253259.

Mohan, M., Banerjee, T., Goud, V.V. 2015. Hydrolysis of bamboo biomass by subcritical water treatment. Bioresource Technology, 191(0), 244-252.

P. Harmsen, W.H., L. Bermudez, R. bakker. 2010. Literature review of physical and chemical pretreatment processes for lignocellulosic biomass. Wageningen UR Food \& Biobased Research. 
Parajó, J.C., Garrote, G., Cruz, J.M., Dominguez, H. 2004. Production of xylooligosaccharides by autohydrolysis of lignocellulosic materials. Trends in Food Science \& Technology, 15(3-4), 115-120.

Press, W., Teukolsky, S., Vetterling, W., Flannery, B. 2007. Numerical recipes 3rd edition: The art of scientific computing.

Pronyk, C., Mazza, G. 2010. Kinetic modeling of hemicellulose hydrolysis from triticale straw in a pressurized low polarity water flow-through reactor. Industrial and Engineering Chemistry Research, 49(14), 6367-6375.

Ranzi, E., Cuoci, A., Faravelli, T., Frassoldati, A., Migliavacca, G., Pierucci, S., Sommariva, S. 2008. Chemical kinetics of biomass pyrolysis. Energy and Fuels, 22(6), 4292-4300.

Rissanen, J.V., Grénman, H., Willför, S., Murzin, D.Y., Salmi, T. 2014. Spruce hemicellulose for chemicals using aqueous extraction: Kinetics, mass transfer, and modeling. Industrial and Engineering Chemistry Research, 53(15), 63416350.

Rogalinski, T., Liu, K., Albrecht, T., Brunner, G. 2008. Hydrolysis kinetics of biopolymers in subcritical water. The Journal of Supercritical Fluids, 46(3), 335341.

Tanoue, K.I., Hinauchi, T., Oo, T., Nishimura, T., Taniguchi, M., Sasauchi, K.I. 2007. Modeling of heterogeneous chemical reactions caused in pyrolysis of biomass particles. Advanced Powder Technology, 18(6), 825-840.

Teo, C.C., Tan, S.N., Yong, J.W.H., Hew, C.S., Ong, E.S. 2010. Pressurized hot water extraction (PHWE). Journal of Chromatography A, 1217(16), 2484-2494.

Tock, L., Gassner, M., Maréchal, F. 2010. Thermochemical production of liquid fuels from biomass: Thermo-economic modeling, process design and process integration analysis. Biomass and Bioenergy, 34(12), 1838-1854.

Yedro, F.M., Cantero, D.A., Pascual, M., García-Serna, J., Cocero, M.J. 2015. Hydrothermal fractionation of woody biomass: Lignin effect on sugars recovery. Bioresource Technology, 191(0), 124-132.

Zhu, G., Zhu, X., Xiao, Z., Zhou, R., Zhu, Y., Wan, X. 2014. Kinetics of peanut shell pyrolysis and hydrolysis in subcritical water. Journal of Material Cycles and Waste Management, 16(3), 546-556. 


\section{Chapter 5}

\section{Table and Figure Captions}

Table 1. Experiments performed and its operational conditions.

Table 2. Final solid mass evolution.

Table 3. A.A.D. of the fittings.

Table 4. Fitted parameters for solid (4.1) and liquid phase (4.2).

Table 5. Simulation of the extracted biomass.

Figure 1. Process flow diagram of the experimental device. T-1 and T-2: type II Millipore water tanks, P-1: High pressure piston pump. P-2: membrane pump, V-1 and V-2: Parker check valve. H-1: electric low temperature heater. H-2: high temperature heater. R-1: fractionation column. V-3: Parker relieve valve. R-2: supercritical reactor. V-4: high temperature valve, HE: cooling heat exchanger. V-5: three way Parker valve, T-3: Falcon flasks. T-4: products deposit.

Figure 2. Scheme of the hydrothermal degradation of biomass at two temperatures (a) and $\mathrm{pH}$ evolution during the process (b).

Figure 3. Reaction pathway (a). Polysaccharide cleaving (b).M: monomer. D: dimer. T: trimer.

Figure 4. TOC evolution with volumetric flow (a) and temperature (b).

Figure 5. Adjustment of the experiment 5. TOC fitting (a), simulation of the concentration of acetic acid (b), sugars C5 (c), sugars C6 (d) and degradation products (e).TOC-EXP: measured TOC. TOC-SIM: simulated TOC. [Acet]-EXP: measured acetic acid concentration. [Acet]-SIM: simulated acetic acid concentration. C5-EXP: measured C5 sugar concentration. C5-SIM: simulated C5 sugar concentration. C6-EXP: measured C6 sugar concentration. C6-SIM: simulated C6 sugar concentration. DP-EXP: measured degradation products concentration. DP-SIM: simulated degradation products concentration.

Figure 6. Overall simulation of the process. (a) Evolution of solid cellulose and hemicellulose. (b) Liquid oligomer concentration. (c) Solid C2 population evolution. (d) Solid HC1 population evolution. HC: total solid hemicellulose content. C: total solid cellulose content. REP: polymerization product in the solid. DO: deacetylated product in 


\section{Chapter 5}

the solid. Ct: total solid concentration. Olig: Liquid oligomer content. DP + [Acet]: addition of the amount of degradation product and acetic acid in the liquid. C5+C6: total sugar amount in the liquid. 
CONCLUSIONS 



\section{Conclusions}

We have validated the hypothesis that the biomass upgrading by supercritical fluid extraction, pyrolysis and hydrothermal fractionation can be simulated using a similar approach (models based on pseudo-components). Thus, the main and specific aims initially proposed have been fulfilled. Biomass pyrolysis, biomass extraction by supercritical fluids and biomass hydrothermal have been comprehensively studied. Also developing Excel-based tools to perform the simulations and the validation of proposed models.

Specifically for supercritical extraction, the model was validated with data of two different samples (sesame seeds and coffee beans) with a different controlling mass transfer resistance. Furthermore, the effect of the main operational variables, e.g. temperature, pressure, particle diameter and volumetric flow, could be also simulated which ensured the physical meaning of the parameters of the model. On the other hand, the developed tool also provided the user with the simulated profiles inside the extraction column, which empowers its utility as a teaching tool too. The average deviations between the experimental data and the simulation was $7.41 \%$ for the sesame seeds and $10.35 \%$ for the coffee beans.

Concerning biomass pyrolysis, an auto-catalytic kinetic model was developed for the thermal degradation of biomass during a thermogravimetric analysis. This could be used to reproduce the experimental behaviour using inert or oxidant atmospheres, samples with different pre-treatments and at isothermal and non-isothermal conditions. Additionally, it was validated with data from a broad range of initial biomasses: seeds, grape skins, woody biomass, pure cellulose, pure hemicellulose and pure lignin. Furthermore, the heating rate effect could be also reproduced by non-Arrhenius' dependence with temperature. On the other hand, since kinetic changes were observed between the different biomasses, an essential role of the initial structure and composition was deduced. This role of the structure was also confirmed for a specific biomass, Brazilian ginseng (Pfaffia glomerata), by XRD and DSC. Finally, the proposed model could be used to perform a composition estimation of the initial biomass from the thermal degradation behaviour. This prediction was acceptable accuracy for cellulose and lignin (differences lower than $7 \%$ ). However, more experiments would be needed to improve the prediction of the other compounds, mainly hemicellulose and the extractives. The average absolute deviation between the simulation and the experimental data was lower than $7 \%$ for all the cases. 


\section{Conclusions}

Finally, two different models for the hydrothermal fractionation of holm oak in a packed bed reactor were proposed. Both options took into account the whole set of physical phenomena involved in the hydrothermal fractionation of biomass, like the oligomer cleavage or the deacetylation. The first approach was a kinetic model that could reproduce the TOC, $\mathrm{pH}$ and acetic acid concentration profiles at the reactor output with relative low differences and in agreement with the data reported by other authors. The specific values for the errors were between $16.3 \%$ and $55.8 \%$ for the TOC, between $5.6 \%$ and $9.7 \%$ for the $\mathrm{pH}$ and between $44.4 \%$ and $84.4 \%$ for the acetic acid. The kinetic constants followed an Arrhenius' dependence with temperature and the physical sense of transfer coefficients and equilibrium was also confirmed. They had a linear dependency with flow and temperature, respectively. Moreover, the particle diameter, volumetric flow and temperature roles were also studied. Being temperature the most predominant of them. The second approach was a modification of the first option, including populations of oligomers for a better simulation of the cleavage. In addition, repolymerisation and sugar degradation reactions were also considered since the temperature was elevated up to higher values for this second study $\left(280^{\circ} \mathrm{C}\right.$ vs $\left.207^{\circ} \mathrm{C}\right)$. The effect of the temperature and flow effect was assessed too, confirming that temperature was the main parameter. Other interesting result was that the volumetric flow just affected the process if temperature was high enough to produce soluble compounds. The validation of this second option was focused on the TOC profile at the reactor output, being the errors around $33 \%$. On the other hand, the kinetic model performance is being currently studied in packed bed reactors of different volumes (from $27.5 \mathrm{~mL}$ to $40 \mathrm{~L}$ ) and different biomasses (holm oak, catalpa and wheat straw) to check if it can be used to simulate the fractionation of biomass in any system and for any biomass type. 
ACKNOWLEDGE MENTS 

Firstly, I would like to acknowledge my supervisors, Doctor Juan García Serna and Professor Francisco Sobron Grañón for the opportunity of working with them for these 5 years and for their guidance during my thesis. In the same way, I also would like to thank the support provided by Professor María José Cocero Alonso and to the whole research group of high pressure processes of the University of Valladolid. Similarly, I would like to acknowledge Professor Smirnova for my secondment at the Thermal Separation Processes Institute at the Technical university of Hamburg

With regards to my colleagues, I want to do a special mention to Doctor Cristian Martín Piqueras, Doctor Maria Pinilla and Doctor Florencia Micaela Yedro for their help during the development of my first works. On the other hand, I really want to thank to those that have been much more than colleagues during this period: my brother, Gianluca, Nerea, Celia, Yoana, Nuria, Victor, Álvaro, Marta and Alberto. Thank you very much for your friendship. In the same way, I also want to thank the people that I met in Hamburg for the time that I spent with them: Joana, Miau, Xia Hu, Wienke, Sheila...

Additionally, I would like to offer my profound gratitude to other two people. Two people that have been near me for more than 10 years. Two people to whom I have to acknowledge a plethora of excellent moments. Ana, Rut, thank you very much for everything.

On the other hand, my old friends, also deserve a mention in these acknowledgements: Carlos, Juan, Sergio and Victor. Thank you. Similarly, my family requires a special mention, without them, I would not be who I am.

Finally, I want to thank the Spanish ministry of Education for funding my research by the FPU program (FPU2013/01516) and to the University of Valladolid for the grants to assist to international congresses. 
Acknowledgements 
References

REFERENCES 



\section{References}

Alvarez-Vasco, C., Zhang, X. 2013. Alkaline hydrogen peroxide pretreatment of softwood: Hemicellulose degradation pathways. Bioresource Technology, 150, 321-327.

Anca-Couce, A. 2016. Reaction mechanisms and multi-scale modelling of lignocellulosic biomass pyrolysis. Progress in Energy and Combustion Science, $53,41-79$.

Arregi, A., Amutio, M., Lopez, G., Bilbao, J., Olazar, M. 2018. Evaluation of thermochemical routes for hydrogen production from biomass: A review. Energy Conversion and Management, 165, 696-719.

Asl, A.H., Khajenoori, M. 2013. Subcritical Water Extraction, Mass Transfer Advances in Sustainable Energy and Environment Oriented Numerical Modeling. InTech.

Biney, P.O., Gyamerah, M., Shen, J., Menezes, B. 2015. Kinetics of the pyrolysis of arundo, sawdust, corn stover and switch grass biomass by thermogravimetric analysis using a multi-stage model. Bioresource Technology, 179, 113-122.

Bobleter, O. 1994. Hydrothermal degradation of polymers derived from plants. Progress in Polymer Science (Oxford), 19(5), 797-841.

Bozell, J.J. 2008. Feedstocks for the future - Biorefinery production of chemicals from renewable carbon. Clean - Soil, Air, Water, 36(8), 641-647.

Cabeza, A., Piqueras, C.M., Sobrón, F., García-Serna, J. 2016. Modeling of biomass fractionation in a lab-scale biorefinery: Solubilization of hemicellulose and cellulose from holm oak wood using subcritical water. Bioresource Technology, 200, 90-102.

Cabeza, A., Sobrón, F., Yedro, F.M., García-Serna, J. 2015. Autocatalytic kinetic model for thermogravimetric analysis and composition estimation of biomass and polymeric fractions. Fuel, 148, 212-225.

Cabeza, A., Sobrón, F., Yedro, F.M., García-Serna, J. 2015. Two-phase modelling and simulation of the hydrothermal fractionation of holm oak in a packed bed reactor with hot pressurized water. Chem. Eng. Sci., 138, 59-70. 


\section{References}

Cai, J., Wu, W., Liu, R. 2014. An overview of distributed activation energy model and its application in the pyrolysis of lignocellulosic biomass. Renewable and Sustainable Energy Reviews, 36, 236-246.

Cantero, D.A., Bermejo, M.D., Cocero, M.J. 2013. Kinetic analysis of cellulose depolymerization reactions in near critical water. The Journal of Supercritical Fluids, 75(0), 48-57.

Capart, R., Khezami, L., Burnham, A.K. 2004. Assessment of various kinetic models for the pyrolysis of a microgranular cellulose. Thermochimica Acta, 417(1), 7989.

Carey, G.F., Finlayson, B.A. 1975. Orthogonal collocation on finite elements. Chemical Engineering Science, 30(5-6), 587-596.

Carpenter, D., Westover, T.L., Czernik, S., Jablonski, W. 2014. Biomass feedstocks for renewable fuel production: a review of the impacts of feedstock and pretreatment on the yield and product distribution of fast pyrolysis bio-oils and vapors. Green Chemistry, 16(2), 384-406.

Carrier, M., Loppinet-Serani, A., Denux, D., Lasnier, J.-M., Ham-Pichavant, F., Cansell, F., Aymonier, C. 2011. Thermogravimetric analysis as a new method to determine the lignocellulosic composition of biomass. Biomass and Bioenergy, 35(1), 298307.

Charles, E.W., Stephen, R.D., Michael, E.H., John, W.B., Catherine, E.S., Liisa, V. 2004. Hydrolysis of Cellulose and Hemicellulose. in: Polysaccharides, CRC Press.

Chen, Q., Zhou, J., Liu, B., Mei, Q., Luo, Z. 2011. Influence of torrefaction pretreatment on biomass gasification technology. Chinese Science Bulletin, 56(14), 1449-1456.

Chen, W.-H., Kuo, P.-C. 2011. Isothermal torrefaction kinetics of hemicellulose, cellulose, lignin and xylan using thermogravimetric analysis. Energy, 36(11), 6451-6460.

Cheng, K., Winter, W.T., Stipanovic, A.J. 2012. A modulated-TGA approach to the kinetics of lignocellulosic biomass pyrolysis/combustion. Polymer Degradation and Stability, 97(9), 1606-1615. 


\section{References}

Cheng, S., Zhu, S. 2009. Lignocellulosic feedstock biorefinery-the future of the chemical and energy industry. BioResources, 4(2), 456-457.

Clark, J.H., Budarin, V., Deswarte, F.E.I., Hardy, J.J.E., Kerton, F.M., Hunt, A.J., Luque, R., Macquarrie, D.J., Milkowski, K., Rodriguez, A., Samuel, O., Tavener, S.J., White, R.J., Wilson, A.J. 2006. Green chemistry and the biorefinery: A partnership for a sustainable future. Green Chemistry, 8(10), 853-860.

Cocero, M.J., Cabeza, Á., Abad, N., Adamovic, T., Vaquerizo, L., Martínez, C.M., Pazo-Cepeda, M.V. 2018. Understanding biomass fractionation in subcritical \& supercritical water. The Journal of Supercritical Fluids, 133, 550-565.

da Silva, R.P.F.F., Rocha-Santos, T.A.P., Duarte, A.C. 2016. Supercritical fluid extraction of bioactive compounds. TrAC Trends in Analytical Chemistry, 76, 4051.

Daouk, E., Van de Steene, L., Paviet, F., Salvador, S. 2015. Thick wood particle pyrolysis in an oxidative atmosphere. Chemical Engineering Science, 126, 608615.

Das, O., Sarmah, A.K. 2015. Mechanism of waste biomass pyrolysis: Effect of physical and chemical pre-treatments. Science of the Total Environment, 537, 323-334.

de Melo, M.M.R., Silvestre, A.J.D., Silva, C.M. 2014. Supercritical fluid extraction of vegetable matrices: Applications, trends and future perspectives of a convincing green technology. The Journal of Supercritical Fluids, 92, 115-176.

Demirbas, A. 2010. Biorefinery Technologies for Biomass Upgrading. Energy Sources, Part A: Recovery, Utilization, and Environmental Effects, 32(16), 1547-1558.

Deneyer, A., Ennaert, T., Sels, B.F. 2018. Straightforward sustainability assessment of sugar-derived molecules from first-generation biomass. Current Opinion in Green and Sustainable Chemistry, 10, 11-20.

Dimitriadis, A., Bezergianni, S. 2017. Hydrothermal liquefaction of various biomass and waste feedstocks for biocrude production: A state of the art review. Renewable and Sustainable Energy Reviews, 68, 113-125. 


\section{References}

Dobbs, J.M., Wong, J.M., Johnston, K.P. 1986. Nonpolar co-solvents for solubility enhancement in supercritical fluid carbon dioxide. Journal of Chemical \& Engineering Data, 31(3), 303-308.

Döker, O., Salgin, U., Yildiz, N., Aydoğmuş, M., Çalimli, A. 2010. Extraction of sesame seed oil using supercritical CO2 and mathematical modeling. Journal of Food Engineering, 97(3), 360-366.

Elyounssi, K., Collard, F.-X., Mateke, J.-a.N., Blin, J. 2012. Improvement of charcoal yield by two-step pyrolysis on eucalyptus wood: A thermogravimetric study. Fuel, 96, 161-167.

Feng, Y., Qi, X., Jian, H.L., Sun, R.C., Jiang, J.X. 2012. Effect of inhibitors on enzymatic hydrolysis and simultaneous saccharification fermentation for lactic acid production from steam explosion pretreated lespedeza stalks. BioResources, $7,3755-3766$.

Ford, E.N.J., Mendon, S.K., Thames, S.F., Rawlins, J.W. 2010. X-ray Diffraction of Cotton Treated with Neutralized Vegetable Oil-based Macromolecular Crosslinkers. JOURNAL OF ENGINEERED FIBERS AND FABRICS, 2(3), 1020.

Franck, E.U. 1970. Water and aqueous solutions at high pressures and temperatures. Pure Appl. Chem, 24, 13-30.

Gao, P., Li, G., Yang, F., Lv, X.N., Fan, H., Meng, L., Yu, X.Q. 2013. Preparation of lactic acid, formic acid and acetic acid from cotton cellulose by the alkaline pretreatment and hydrothermal degradation. Industrial Crops and Products, 48, 6167.

Gallina, G., Cabeza, Á., Grénman, H., Biasi, P., García-Serna, J., Salmi, T. 2018. Hemicellulose extraction by hot pressurized water pretreatment at $160^{\circ} \mathrm{C}$ for 10 different woods: Yield and molecular weight. The Journal of Supercritical Fluids, $133,716-725$.

Garrote, G., Domínguez, H., Parajó, J.C. 2002. Interpretation of deacetylation and hemicellulose hydrolysis during hydrothermal treatments on the basis of the severity factor. Process Biochemistry, 37(10), 1067-1073. 


\section{References}

Gollakota, A.R.K., Kishore, N., Gu, S. 2018. A review on hydrothermal liquefaction of biomass. Renewable and Sustainable Energy Reviews, 81, 1378-1392.

Haghighat Khajavi, S., Kimura, Y., Oomori, T., Matsuno, R., Adachi, S. 2005. Kinetics on sucrose decomposition in subcritical water. LWT Food Sci. Technol., 38, 297 302.

Henley, E.J., Seader, J.D. 1981. Equilibrium-Stage Separation Operations in Chemical Engineering. John Wiley \& Sons, Inc.

Herrero, M., Mendiola, J.A., Cifuentes, A., Ibáñez, E. 2010. Supercritical fluid extraction: Recent advances and applications. Journal of Chromatography A, 1217(16), 2495-2511.

Honarvar, B., Sajadian, S.A., Khorram, M., Samimi, A. 2013. Mathematical modeling of supercritical fluid extraction of oil from canola and sesame seeds. Brazilian Journal of Chemical Engineering, 30, 159-166.

Hu, M., Chen, Z., Wang, S., Guo, D., Ma, C., Zhou, Y., Chen, J., Laghari, M., Fazal, S., Xiao, B., Zhang, B., Ma, S. 2016. Thermogravimetric kinetics of lignocellulosic biomass slow pyrolysis using distributed activation energy model, Fraser-Suzuki deconvolution, and iso-conversional method. Energy Conversion and Management, 118, 1-11.

Huang, Z., Shi, X.-h., Jiang, W.-j. 2012. Theoretical models for supercritical fluid extraction. Journal of Chromatography A, 1250, 2-26.

Jae, J., Coolman, R., Mountziaris, T.J., Huber, G.W. 2014. Catalytic fast pyrolysis of lignocellulosic biomass in a process development unit with continual catalyst addition and removal. Chemical Engineering Science, 108, 33-46.

Jahirul, M., Rasul, M., Chowdhury, A., Ashwath, N. 2012. Biofuels Production through Biomass Pyrolysis - A Technological Review. Energies, 5(12), 4952.

Kabir, G., Hameed, B.H. 2017. Recent progress on catalytic pyrolysis of lignocellulosic biomass to high-grade bio-oil and bio-chemicals. Renewable and Sustainable Energy Reviews, 70, 945-967. 


\section{References}

Kan, T., Strezov, V., Evans, T.J. 2016. Lignocellulosic biomass pyrolysis: A review of product properties and effects of pyrolysis parameters. Renewable and Sustainable Energy Reviews, 57, 1126-1140.

Kastanaki, E., Vamvuka, D., Grammelis, P., Kakaras, E. 2002. Thermogravimetric studies of the behavior of lignite-biomass blends during devolatilization. Fuel Processing Technology, 77-78(0), 159-166.

King, D. 2009. The future of industrial biorefineries. Worl Economic Forum.

Klemm, D., Schmauder, H.-P., Heinze, T. 2005. Cellulose. in: Biopolymers Online, Wiley-VCH Verlag GmbH \& Co. KGaA.

Knez, Ž., Markočič, E., Leitgeb, M., Primožič, M., Knez Hrnčič, M., Škerget, M. 2014. Industrial applications of supercritical fluids: A review. Energy, 77, 235-243.

Kritzer, P., Boukis, N., Dinjus, E. 1999. Factors controlling corrosion in hightemperature aqueous solutions: a contribution to the dissociation and solubility data influencing corrosion processes. The Journal of Supercritical Fluids, 15(3), 205-227.

Kruse, A., Dinjus, E. 2007. Hot compressed water as reaction medium and reactant: Properties and synthesis reactions. The Journal of Supercritical Fluids, 39(3), 362380.

Kumar, S., Gupta, R., Lee, Y.Y., Gupta, R.B. 2010. Cellulose pretreatment in subcritical water: Effect of temperature on molecular structure and enzymatic reactivity. Bioresour. Technol., 101, 1337-1347.

Lack, E., Seidlitz, H. 1993. Commercial scale decaffeination of coffee and tea using supercritical CO2. in: Extraction of Natural Products Using Near-Critical Solvents, (Eds.) M.B. King, T.R. Bott, Springer Netherlands, pp. 101-139.

Li, H.-Q., Jiang, W., Jia, J.-X., Xu, J. 2014. pH pre-corrected liquid hot water pretreatment on corn stover with high hemicellulose recovery and low inhibitors formation. Bioresour. Technol., 153, 292-299.

Lin, R., Cheng, J., Ding, L., Song, W., Qi, F., Zhou, J., Cen, K. 2015. Subcritical water hydrolysis of rice straw for reducing sugar production with focus on degradation by-products and kinetic analysis. Bioresource Technology, 186, 8-14. 


\section{References}

Lv, D., Xu, M., Liu, X., Zhan, Z., Li, Z., Yao, H. 2010. Effect of cellulose, lignin, alkali and alkaline earth metallic species on biomass pyrolysis and gasification. Fuel Processing Technology, 91(8), 903-909.

M. Sefik Tunc, A.R.P.v.H. 2008. Hemicellulose extraction of mixed southern hardwood with water at $150{ }^{\circ} \mathrm{C}$ : Effect of time. Industrial \& Engineering Chemistry Research, 47(18), 7031-7037.

Mangut, V., Sabio, E., Gañán, J., González, J.F., Ramiro, A., González, C.M., Román, S., Al-Kassir, A. 2006. Thermogravimetric study of the pyrolysis of biomass residues from tomato processing industry. Fuel Processing Technology, 87(2), 109-115.

Manivannan, G., Sawan, S.P. 1998. 1 - The Supercritical State. in: Supercritical Fluid Cleaning, (Ed.) J.M.P. Sawan, William Andrew Publishing. Westwood, NJ, pp. $1-21$.

Meng, L.Y., Kang, S.M., Zhang, X.M., Wu, Y.Y., Xu, F., Sun, R.C. 2012. Fractional pretreatment of hybrid poplar for accelerated enzymatic hydrolysis: Characterization of cellulose-enriched fraction. Bioresource Technology, 110, 308-313

Miller-Chou, B.A., Koenig, J.L. 2003. A review of polymer dissolution. Progress in Polymer Science, 28(8), 1223-1270.

Minowa, T., Zhen, F., Ogi, T. 1998. Cellulose decomposition in hot-compressed water with alkali or nickel catalyst. The J. of Supercrit. Fluids, 13, 253-259.

Mohan, M., Banerjee, T., Goud, V.V. 2015. Hydrolysis of bamboo biomass by subcritical water treatment. Bioresource Technology, 191, 244-252.

Moniz, P., Pereira, H., Quilhó, T., Carvalheiro, F. 2013. Characterisation and hydrothermal processing of corn straw towards the selective fractionation of hemicelluloses. Industrial Crops and Products, 50(0), 145-153.

Mullen, C.A., Boateng, A.A. 2008. Chemical Composition of Bio-oils Produced by Fast Pyrolysis of Two Energy Crops. Energy \& Fuels, 22(3), 2104-2109. 


\section{References}

Nahar, L., Sarker, S. 2012. Supercritical Fluid Extraction in Natural Products Analyses. in: Natural Products Isolation, (Eds.) S.D. Sarker, L. Nahar, Vol. 864, Humana Press, pp. 43-74.

Negro, M.J., Manzanares, P., Oliva, J.M., Ballesteros, I., Ballesteros, M. 2003. Changes in various physical/chemical parameters of Pinus pinaster wood after steam explosion pretreatment. Biomass and Bioenergy, 25(3), 301-308.

Nerome, H., Ito, M., Machmudah, S., Wahyudiono, Kanda, H., Goto, M. Extraction of phytochemicals from saffron by supercritical carbon dioxide with water and methanol as entrainer. The Journal of Supercritical Fluids.

OCDE. 2009. The Bioeconomy to 2030: designing a policy agenda, Vol. 2014.

Ogawa, T., Koizumi, S., Adachi, S. 2014. Thermal analysis of drying process of durum wheat dough under the programmed temperature-rising conditions. Food and Bioproducts Processing, 92(1), 9-13.

Organisation, T.E.P.S. 2011. THE EUROPEAN BIOECONOMY IN 2030. Delivering Sustainable Growth by addressing the Grand Societal Challenges, pp. 1-24.

Oudenhoven, S.R.G., van der Ham, A.G.J., van den Berg, H., Westerhof, R.J.M., Kersten, S.R.A. 2016. Using pyrolytic acid leaching as a pretreatment step in a biomass fast pyrolysis plant: Process design and economic evaluation. Biomass and Bioenergy, 95, 388-404.

P. Harmsen, W.H., L. Bermudez, R. bakker. 2010. Literature review of physical and chemical pretreatment processes for lignocellulosic biomass. Wageningen UR Food \& Biobased Research.

Parajó, J.C., Garrote, G., Cruz, J.M., Dominguez, H. 2004. Production of xylooligosaccharides by autohydrolysis of lignocellulosic materials. Trends in Food Science \& Technology, 15(3-4), 115-120.

Parascanu, M.M., Sandoval-Salas, F., Soreanu, G., Valverde, J.L., Sanchez-Silva, L. 2017. Valorization of Mexican biomasses through pyrolysis, combustion and gasification processes. Renewable and Sustainable Energy Reviews, 71, 509-522.

Peker, H., Srinivasan, M. P., Smith, J. M. and McCoy, B. J. 1992. Caffeine extraction rates from coffee beans with supercritical carbon dioxide. AIChE J, 38, 761-770. 


\section{References}

Piqueras, C.M., Cabeza, Á., Gallina, G., Cantero, D.A., García-Serna, J., Cocero, M.J. 2017. Online integrated fractionation-hydrolysis of lignocellulosic biomass using sub- and supercritical water. Chemical Engineering Journal, 308, 110-125.

Press, W., Teukolsky, S., Vetterling, W., Flannery, B. 2007. Numerical recipes 3rd edition: The art of scientific computing.

Pronyk, C., Mazza, G. 2010. Kinetic modeling of hemicellulose hydrolysis from triticale straw in a pressurized low polarity water flow-through reactor. Industrial and Engineering Chemistry Research, 49(14), 6367-6375.

Radlein, D., Piskorz, J., Scott, D.S. 1991. Fast pyrolysis of natural polysaccharides as a potential industrial process. Journal of Analytical and Applied Pyrolysis, 19, 4163.

Rai, A., Mohanty, B., Bhargava, R. 2016. Supercritical extraction of sunflower oil: A central composite design for extraction variables. Food Chemistry, 192, 647-659.

Rambo, M.K.D., Ferreira, M.M.C. 2015. Determination of Cellulose Crystallinity of Banana Residues Using Near Infrared Spectroscopy and Multivariate Analysis. Journal of the Brazilian Chemical Society, 26, 1491-1499.

Ranzi, E., Corbetta, M., Manenti, F., Pierucci, S. 2014. Kinetic modeling of the thermal degradation and combustion of biomass. Chemical Engineering Science, 110, 212.

Ranzi, E., Cuoci, A., Faravelli, T., Frassoldati, A., Migliavacca, G., Pierucci, S., Sommariva, S. 2008. Chemical Kinetics of Biomass Pyrolysis. Energy \& Fuels, 22(6), 4292-4300.

Reynolds, W., Singer, H., Schug, S., Smirnova, I. 2015. Hydrothermal flow-through treatment of wheat-straw: Detailed characterization of fixed-bed properties and axial dispersion. Chemical Engineering Journal, 281, 696-703.

Reynolds, W., Smirnova, I. 2018. Hydrothermal flow-through treatment of wheat straw: Coupled heat and mass transfer modeling with changing bed properties. The Journal of Supercritical Fluids, 133, 625-639. 


\section{References}

Rissanen, J.V., Grénman, H., Willför, S., Murzin, D.Y., Salmi, T. 2014. Spruce hemicellulose for chemicals using aqueous extraction: Kinetics, mass transfer, and modeling. Industrial and Engineering Chemistry Research, 53(15), 6341-6350.

Rivas, S., González-Muñoz, M.J., Santos, V., Parajó, J.C. 2014. Acidic processing of hemicellulosic saccharides from pine wood: Product distribution and kinetic modeling. Bioresource Technology, 162, 192-199.

Rogalinski, T., Liu, K., Albrecht, T., Brunner, G. 2008. Hydrolysis kinetics of biopolymers in subcritical water. The Journal of Supercritical Fluids, 46(3), 335341.

Ru, B., Wang, S., Dai, G., Zhang, L. 2015. Effect of Torrefaction on Biomass Physicochemical Characteristics and the Resulting Pyrolysis Behavior. Energy \& Fuels, 29(9), 5865-5874.

S. Völker, T.R. 2002. Thermokinetic investigation of cellulose pyrolysis. Impact of initial and final mass of kinetics results. Journal of Analytical and Applied Pyrolysis, 62, 165-177.

Santucci, B.S., Maziero, P., Rabelo, S.C., Curvelo, A.A.S., Pimenta, M.T.B. 2015. Autohydrolysis of Hemicelluloses from Sugarcane Bagasse During Hydrothermal Pretreatment: a Kinetic Assessment. BioEnergy Research, 8(4), 1778-1787.

Sasaki, M., Furukawa, M., Minami, K., Adschiri, T., Arai, K. 2002. Kinetics and mechanism of cellobiose hydrolysis and retro-aldol condensation in subcritical and supercritical water. Industrial and Engineering Chemistry Research, 41(26), 6642-6649.

Scott, S.A., Dennis, J.S., Davidson, J.F., Hayhurst, A.N. 2006. An algorithm for determining the kinetics of devolatilisation of complex solid fuels from thermogravimetric experiments. Chemical Engineering Science, 61(8), 23392348.

Segal, L., Creely, J.J., A.E. Martin, J., Conrad, C.M. 1959. An Empirical Method for Estimating the Degree of Crystallinity of Native Cellulose Using the X-Ray Diffractometer. Textile Research Journal, 29(10), 786-794. 


\section{References}

Seo, D.K., Park, S.S., Hwang, J., Yu, T.-U. 2010. Study of the pyrolysis of biomass using thermo-gravimetric analysis (TGA) and concentration measurements of the evolved species. Journal of Analytical and Applied Pyrolysis, 89(1), 66-73.

Serapiglia, M.J., Cameron, K.D., Stipanovic, A.J., Smart, L.B. 2009. Analysis of Biomass Composition Using High-Resolution Thermogravimetric Analysis and Percent Bark Content for the Selection of Shrub Willow Bioenergy Crop Varieties. BioEnergy Research, 2(1), 1-9.

Serapiglia, M.J., Cameron, K.D., Stipanovic, A.J., Smart, L.B. 2008. High-resolution Thermogravimetric Analysis For Rapid Characterization of Biomass Composition and Selection of Shrub Willow Varieties. Applied Biochemistry and Biotechnology, 145(1), 3-11.

Shafizadeh, F. 1982. Introduction to pyrolysis of biomass. Journal of Analytical and Applied Pyrolysis, 3(4), 283-305.

Sharma, A., Pareek, V., Wang, S., Zhang, Z., Yang, H., Zhang, D. 2014. A phenomenological model of the mechanisms of lignocellulosic biomass pyrolysis processes. Computers \& Chemical Engineering, 60, 231-241.

Sharma, A., Pareek, V., Zhang, D. 2015. Biomass pyrolysis-A review of modelling, process parameters and catalytic studies. Renewable and Sustainable Energy Reviews, 50, 1081-1096.

Silva Filho, C.G.d., Milioli, F.E. 2008. A thermogravimetric analysis of the combustion of a Brazilian mineral coal. Química Nova, 31, 98-103.

Slopiecka, K., Bartocci, P., Fantozzi, F. 2012. Thermogravimetric analysis and kinetic study of poplar wood pyrolysis. Applied Energy, 97, 491-497.

Sovová, H. 1994. Rate of the vegetable oil extraction with supercritical CO2-I. Modelling of extraction curves. Chemical Engineering Science, 49(3), 409-414.

Spinelli, S., Conte, A., Lecce, L., Padalino, L., Del Nobile, M.A. 2016. Supercritical carbon dioxide extraction of brewer's spent grain. The Journal of Supercritical Fluids, 107, 69-74. 


\section{References}

Sunarso, J., Ismadji, S. 2009. Decontamination of hazardous substances from solid matrices and liquids using supercritical fluids extraction: A review. Journal of Hazardous Materials, 161(1), 1-20.

Tanoue, K.I., Hinauchi, T., Oo, T., Nishimura, T., Taniguchi, M., Sasauchi, K.I. 2007. Modeling of heterogeneous chemical reactions caused in pyrolysis of biomass particles. Adv. Powder Technol., 18, 825-840.

Tekin, K., Karagöz, S., Bektaş, S. 2014. A review of hydrothermal biomass processing. Renewable and Sustainable Energy Reviews, 40, 673-687.

Teo, C.C., Tan, S.N., Yong, J.W.H., Hew, C.S., Ong, E.S. 2010. Pressurized hot water extraction (PHWE). Journal of Chromatography A, 1217(16), 2484-2494.

Tock, L., Gassner, M., Maréchal, F. 2010. Thermochemical production of liquid fuels from biomass: Thermo-economic modeling, process design and process integration analysis. Biomass Bioenergy, 34, 1838-1854.

Van de Velden, M., Baeyens, J., Brems, A., Janssens, B., Dewil, R. 2010. Fundamentals, kinetics and endothermicity of the biomass pyrolysis reaction. Renewable Energy, $35(1), 232-242$.

van der Stelt, M.J.C., Gerhauser, H., Kiel, J.H.A., Ptasinski, K.J. 2011. Biomass upgrading by torrefaction for the production of biofuels: A review. Biomass and Bioenergy, 35(9), 3748-3762.

Vardanega, R., Carvalho, P.I.N., Albarelli, J.Q., Santos, D.T., Meireles, M.A.A. Techno-economic evaluation of obtaining Brazilian ginseng extracts in potential production scenarios. Food and Bioproducts Processing, 101, 45-55.

Villadsen, J.V., Stewart, W.E. 1995. Solution of boundary-value problems by orthogonal collocation. Chemical Engineering Science, 50(24), 3981-3996.

Völker, S., Rieckmann, T. 2002. Thermokinetic investigation of cellulose pyrolysis impact of initial and final mass on kinetic results. Journal of Analytical and Applied Pyrolysis, 62(2), 165-177.

Wang, S., Dai, G., Yang, H., Luo, Z. 2017. Lignocellulosic biomass pyrolysis mechanism: A state-of-the-art review. Progress in Energy and Combustion Science, 62, 33-86. 


\section{References}

Widjaya, E.R., Chen, G., Bowtell, L., Hills, C. 2018. Gasification of non-woody biomass: A literature review. Renewable and Sustainable Energy Reviews, 89, 184-193.

Williams, P.T., Besler, S. 1996. The Influence of Temperature and Heating Rate on the Slow Pyrolysis of Biomass. Renewable Energy, 7(3), 233-250.

Yedro, F.M., Cantero, D.A., Pascual, M., García-Serna, J., Cocero, M.J. 2015. Hydrothermal fractionation of woody biomass: Lignin effect on sugars recovery. Bioresour. Technol., 191, 124-132.

Yoo, C.G., Pu, Y., Ragauskas, A.J. 2017. Ionic liquids: Promising green solvents for lignocellulosic biomass utilization. Current Opinion in Green and Sustainable Chemistry, 5, 5-11.

Yoon, S.Y., Han, S.H., Shin, S.J. 2014. The effect of hemicelluloses and lignin on acid hydrolysis of cellulose. Energy, 77(0), 19-24.

Zabaniotou, A., Ioannidou, O., Antonakou, E., Lappas, A. 2008. Experimental study of pyrolysis for potential energy, hydrogen and carbon material production from lignocellulosic biomass. International Journal of Hydrogen Energy, 33(10), 2433 2444.

Zakaria, M.R., Hirata, S., Hassan, M.A. 2015. Hydrothermal pretreatment enhanced enzymatic hydrolysis and glucose production from oil palm biomass. Bioresource Technology, 176(0), 142-148.

Zhu, G., Zhu, X., Fan, Q., Wan, X. 2011. Production of reducing sugars from bean dregs waste by hydrolysis in subcritical water. Journal of Analytical and Applied Pyrolysis, 90(2), 182-186.

Zhu, G., Zhu, X., Xiao, Z., Zhou, R., Zhu, Y., Wan, X. 2014. Kinetics of peanut shell pyrolysis and hydrolysis in subcritical water. Journal of Material Cycles and Waste Management, 16(3), 546-556. 
References 

Appendix 1

Appendix 1. Other research works developed during the thesis

Cocero, M.J., Cabeza, Á., Abad, N., Adamovic, T., Vaquerizo, L., Martínez, C.M., Pazo-Cepeda, M.V. 2018. Understanding biomass fractionation in subcritical \& supercritical water. The Journal of Supercritical Fluids, 133, 550-565.

Gallina, G., Cabeza, Á., Biasi, P., García-Serna, J. 2016. Optimal conditions for hemicelluloses extraction from Eucalyptus globulus wood: hydrothermal treatment in a semi-continuous reactor. Fuel Process. Technol., 148, 350-360.

Gallina, G., Cabeza, Á., Grénman, H., Biasi, P., García-Serna, J., Salmi, T. 2018. Hemicellulose extraction by hot pressurized water pretreatment at $160^{\circ} \mathrm{C}$ for 10 different woods: Yield and molecular weight. The Journal of Supercritical Fluids, $133,716-725$.

Piqueras, C.M., Cabeza, Á., Gallina, G., Cantero, D.A., García-Serna, J., Cocero, M.J. 2017. Online integrated fractionation-hydrolysis of lignocellulosic biomass using sub- and supercritical water. Chem. Eng. J., 308, 110-125. 
Appendix 1 
Appendix 2

\section{Appendix 2. Further work: "Biomass hydrothermal fractionation modelling for different reactors: kinetics \& mass transfer"}

\section{Introduction}

The last step of the research developed during the thesis is still in progress. The idea was to test the kinetic model developed in Chapter 4 with data from packed bed reactors of higher volume and different biomasses. Thus, its range of validity could be better defined and a more suitable tool for scale-up purposes could be developed. This work was started in collaboration with the Thermal Separation Processes Institute at the Technical University of Hamburg.

The selected biomasses were crops wastes and woods in order to have a high degree of variability to check the model. Specifically, they were holm oak, since it was used in Chapter 4, wheat straw, which is one of the most common residues from agriculture and catalpa, because it is a common tree for decoration. Holm oak was treated in a packed bed reactor of a volume of $40.0 \mathrm{~L}$, wheat straw in a $3.0 \mathrm{~L}$ reactor and catalpa in a $6.0 \mathrm{~L}$ reactor. Regarding operational conditions, temperature was fixed between 140 and $210^{\circ} \mathrm{C}$ to focus the study on the extraction of hemicellulose and the residence time was around $10 \mathrm{~min}$ to boost the extraction without degrading the liquid output.

\section{Experimental}

The experimental data were obtained from 4 different packed reactors $(27.5 \mathrm{~mL}, 3.0 \mathrm{~L}$, 6.0 L and $40.0 \mathrm{~L}$ ) where a certain amount (from $5.0 \mathrm{~g}$ to $10.0 \mathrm{~kg}$ ) of biomass was introduced. Then, hot pressurized water was fed, which implied the extraction of a fraction of the initial sample. The individual characteristics of each reactor, like material or length/diameter ratio, can be found in the works of Cabeza et al (Cabeza et al., 2015), Reynolds et al (Reynolds \& Smirnova, 2017), Gallina et al (Gallina et al., 2018) and Reynolds et al (Reynolds et al., 2016a), respectively. The performed experiments end their characteristics are listed in Table 1. From this table, it can be also checked that the data comes from different sources and the details of the procedures, analytics and set-up for each case can be found in the works of Cabeza et al. (Cabeza et al., 2015), Gallina et al (Gallina et al., 2018) and Reynolds et al (Reynolds \& Smirnova, 2017), respectively. However, the fractionation of holm oak in the $40.0 \mathrm{~L}$ reactor was not previously performed in any other work and, for this reason, some details are provided in this section. 
Appendix 2

Table 1. Set of experiments performed

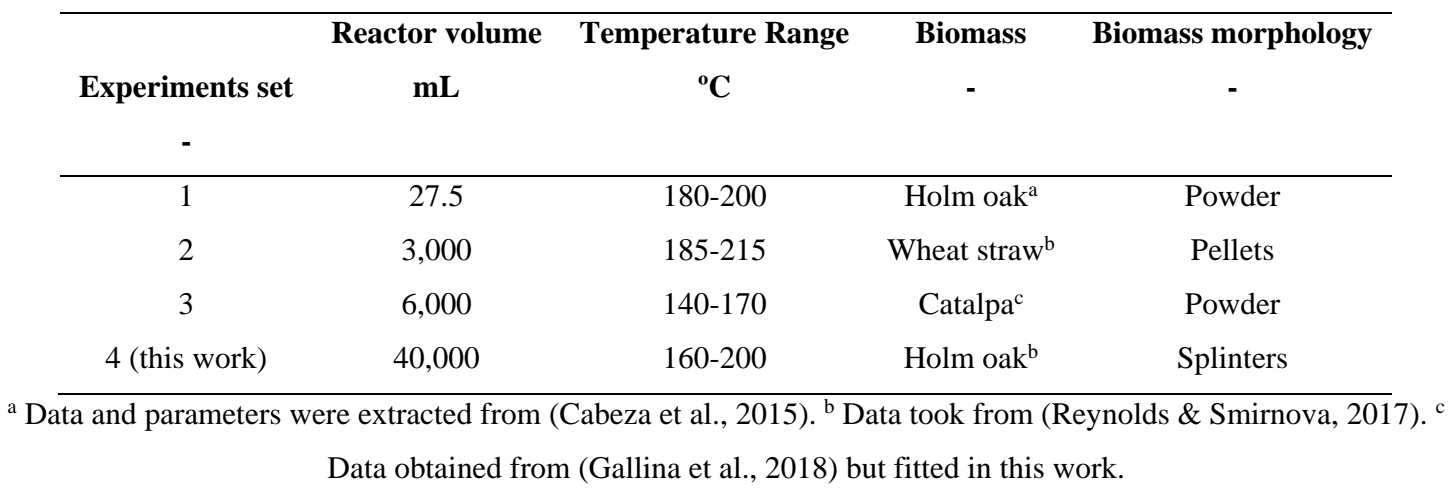

\subsection{Material and methods}

Holm oak was used as splinters of a length of $13 \mathrm{~cm}$ and a diameter of $2-3 \mathrm{~cm}$. Its characterisation was done following the National Renewable Energy Laboratory (NREL) - Determination of Structural Carbohydrates and Lignin in Biomass- standards (A. Sluiter, 2008). The whole procedure for this characterisation, reagents and the methods used to analyse the samples can be found in Cabeza et al. (Cabeza et al., 2015).

\subsection{Set-up and procedure}

The system consisted of a stainless-steel reactor of $40 \mathrm{~L}$ with a length and internal diameter of 720 and $26.5 \mathrm{~cm}$, respectively. More details about this reactor and the plant configuration can be found in Reynolds et al. (Reynolds et al., 2016b)). This reactor was charged with $10 \mathrm{~kg}$ of holm oak as splinters, without removing the bark. Once the reactor was full of biomass, hot pressurized water at the desired temperature was fed $(180 \mathrm{~kg} / \mathrm{h})$ from the bottom, starting the fractionation. Finally, the oligomers, sugars, acetic acid, degradation products, soluble lignin and $\mathrm{pH}$ profiles were measured at the output of the reactor to validate the model (aliquots were taken and analysed off-line). It must be remarked that the reactor heating followed a different procedure depending on the set. In sets 1 and 3 the reactor was initially charged with the raw material and water, being preheated up to the desired temperature before starting to feed the hot pressurized water. In contrast, in sets 2 and 4, this preliminary heating was not done, directly feeding the system with hot water at the desired temperature. 


\section{Modelling}

Initially, the model proposed would be the same as the explained in Chapter 4. However, the work has not finished yet. Thus, some variations are still possible. For instance, the reaction path way (Figure 1) had to be modified as follows: (1) a direct deacetylation of hemicellulose was assumed, (2) the sugar degradation (Kabyemela et al., 1999; Lü \& Saka, 2012) was included, (3) the soluble lignin extraction (Mok \& Antal, 1992) was considered, (4) the fact that a certain amount of hemicellulose cannot be recovered at the operational conditions (Pronyk \& Mazza, 2010) was taken into account and (5) it was stated that only a part of the inorganics can be extracted since they would be inside the unaffected biomass fractions: lignin and cellulose. The last statement, the fact that some ashes can be still present in the solid after and hydrothermal pre-treatments, is in line with the results displayed in Chapter 2 since the inert content of the hydrolysed seeds was not zero (Table 1 of the Chapter 2). Moreover, it can be also checked that this new mechanism is something in between the proposals done in Chapters 4 and 5.

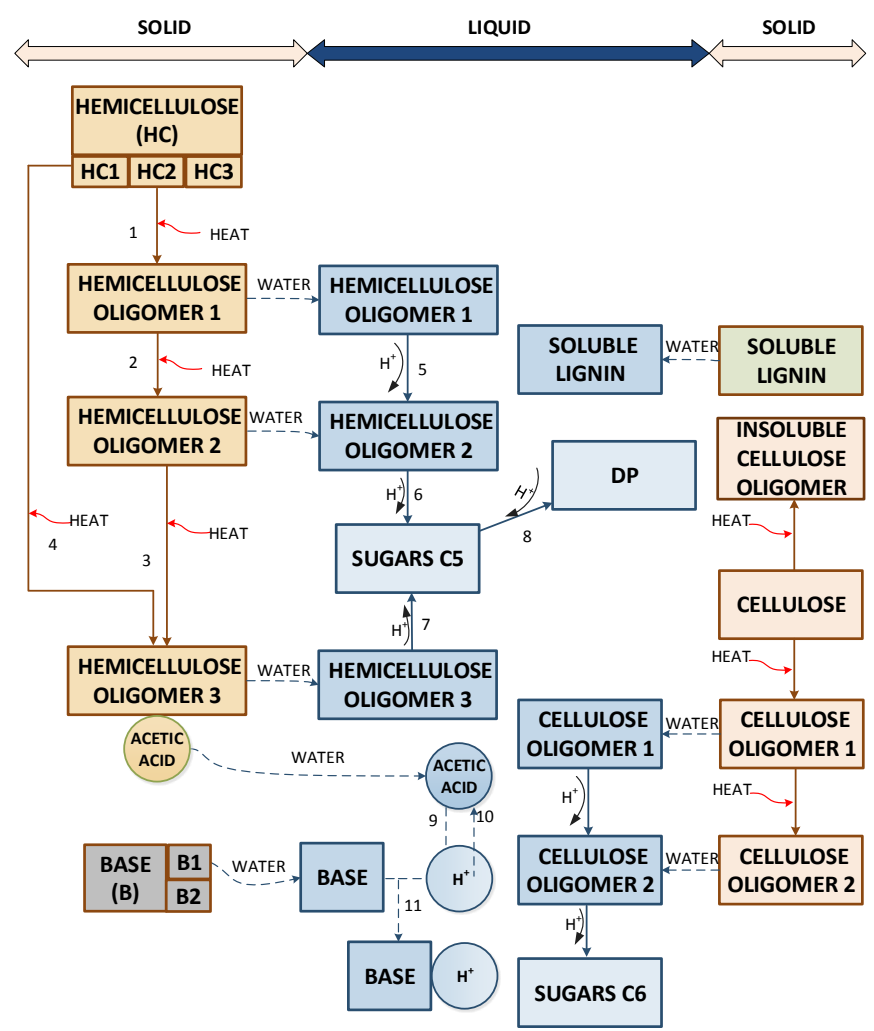

Figure 1. Overall reaction pathway for hemicellulose hydrothermal fractionation. Note that HC1 refers to the hemicellulose directly deacetylated, HC2 to the hemicellulose that suffers the cleaving process and HC 3 to the hemicellulose unaffected by the treatment. Similarly, B1 is the amount of inorganics extracted during the fractionation and $\mathrm{B} 2$ is the fraction that remains in the matrix. Blue rectangles are the compounds liquid phase, whereas the others refer to the substances in the solid. 


\subsection{Fittings}

The fittings were done minimizing the Absolute Average Deviation (Eq. 1) between the calculated and experimental profiles (oligomers, sugars, degradation products, $\mathrm{pH}$, acetic acid and soluble lignin). The optimization method was the Broyden-Fletcher-GoldfarbShanno's method. The parameters obtained in Chapter 4 were used as the initial seed for this optimization problem.

$$
\text { A.A.D. }=\sum_{i=1}^{o} \frac{1}{o} \cdot\left|\frac{X_{\text {exp }}-X_{\text {sim }}}{X_{\text {exp }}}\right| \cdot 100
$$

\section{Results}

Since the work has not been still finished, just some preliminary and general results can be shown.

\subsection{Adjustments}

Figure 2 and Figure 3 display the experimental and simulated profiles for the fractionation of wheat straw and holm oak (reactor of $40 \mathrm{~L}$ ) at $200{ }^{\circ} \mathrm{C}$, respectively. It can be observed that the proposed model could reproduce quite well the experimental behavior for all the components in both cases. However, it is clear that there was a higher error for the holm oak. Which was expected since the reactor for this case was 145 times higher than the used in Chapter 4. Thus, many of the assumptions done to develop the model, such a constant temperature inside the whole reactor or a globalized solid phase, would not be really true. On the other hand, it can be observed that the $\mathrm{pH}$ could not be well calculated at the beginning of the process for the wheat straw (Figure 2-d). This discrepancy can be due to the differences in composition between crops and woody biomass (different lignin and ashes content), which would require a deeper analysis of the interaction between the protons and the basic compounds initially present in the raw material. Additionally, it also interesting the fact that two different peaks can be observed in the acetic acid profile for the wheat straw (Figure 2-c), whereas just one was obtained for the oligomer and sugars profiles (Figure 2-a and Figure 2-b). The double peak could be related with the initial heating of the reactor, which involved around $10 \mathrm{~min}$. During this time biomass would start to deacetylate following a reaction independent of the cleavage (reaction 4 in Figure 1), releasing acetic acid, and explaining why at the beginning of the process a peak is 
observed. Later, the concentration started to decrease because hemicellulose would have been almost totally deactivated during this initial heating. The second peak could be due to a slight deacetylation of the hemicellulose during the cleavage (reaction 3 in Figure 1). In contrast, the acetic acid just showed a peak for the holm oak (Figure 3-c). Thus, in this case, deacetylation would mainly depend on the cleavage. Additionally, it can be also checked that for both cases, wheat straw and holm oak, the maximum for the oligomers (Figure 2-a and Figure 3-a, respectively) and sugars (Figure 2-b and Figure 3-b, respectively) did not take place at the same time. Sugars' peak was always a bit delayed. This difference could be related with the kinetics of each compound, being the oligomer hydrolysis much faster than the sugar degradation. A result that agrees with the theoretical relation between the activation energy and the molecular weight of a polymer: the longer, the easier cleavage.
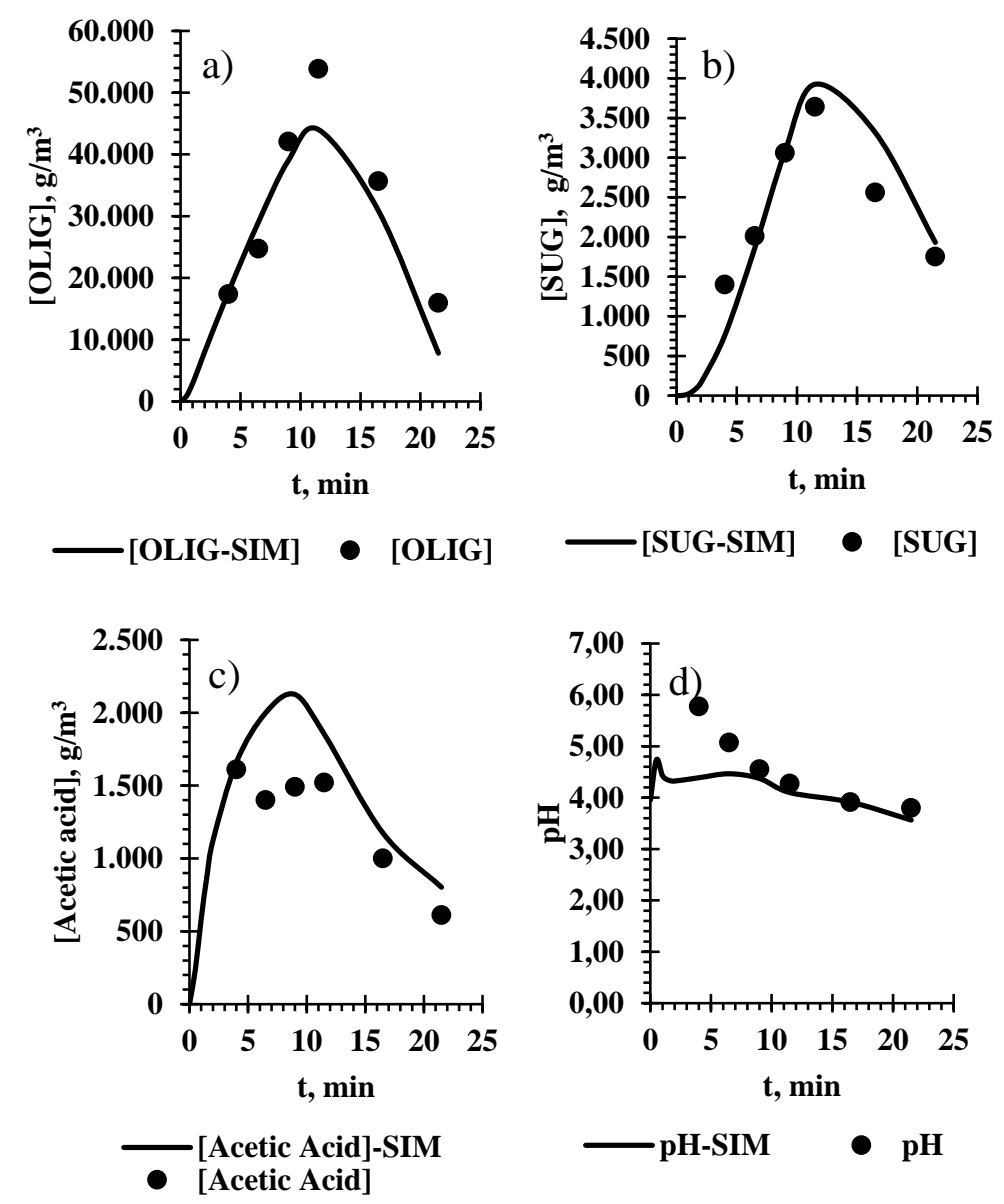

Figure 2. Experimental and simulated oligomer (a), sugar (b), acetic acid (c) and pH (d) profiles for the wheat straw hydrothermal fractionation in the packed bed reactor of $3.0 \mathrm{~L}$ at $200{ }^{\circ} \mathrm{C}$. [X]-SIM: simulated value of the concentration for the compound " $\mathrm{X}$ "; $[\mathrm{X}]$ : experimental value for the concentration of the compound "X"; OLIG: oligomers and SUG: sugars 

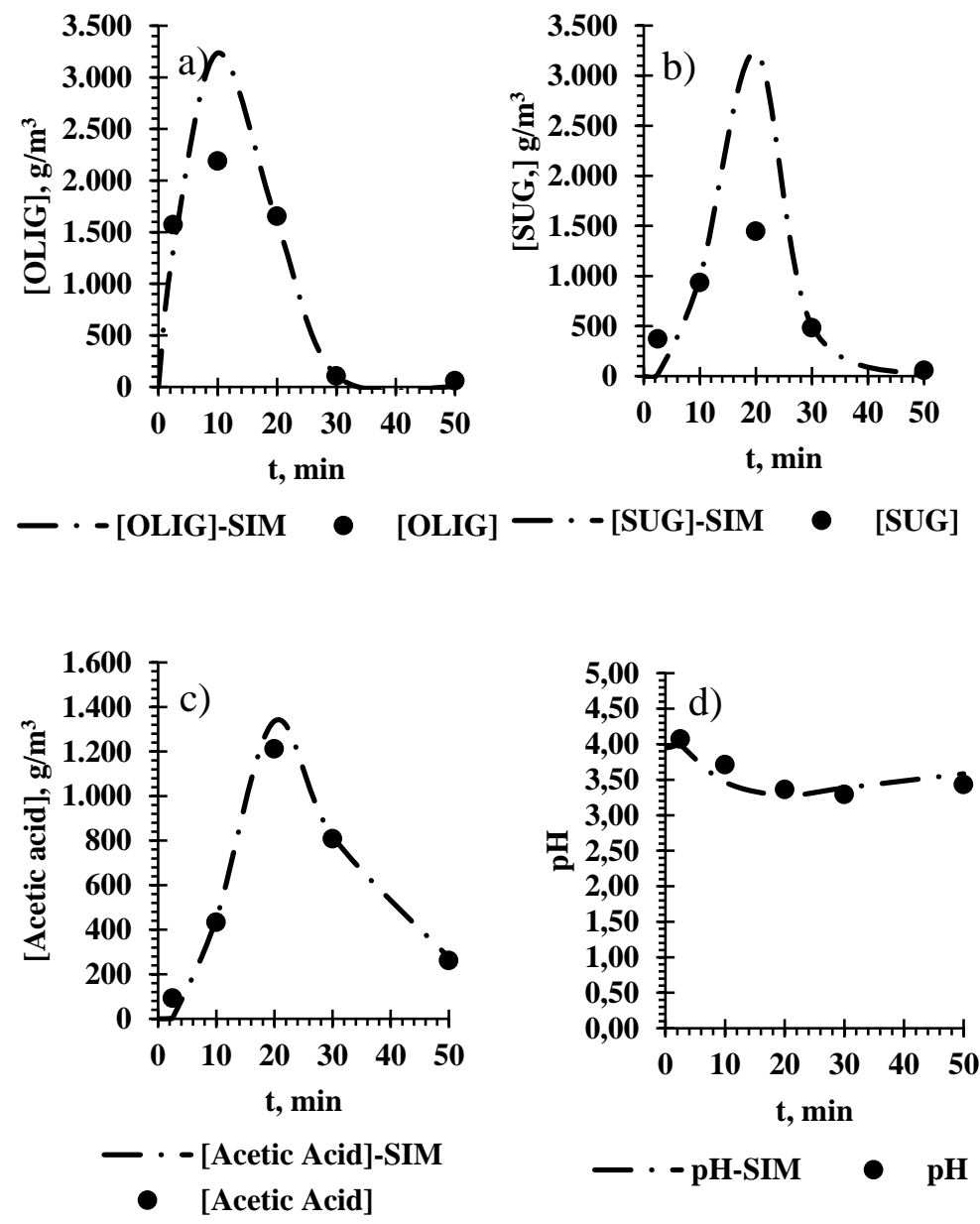

Figure 3. Experimental and simulated oligomer (a), sugar (b), acetic acid (c) and pH (d) profiles for the holm oak hydrothermal fractionation in the packed bed reactor of $40.0 \mathrm{~L}$ at $200{ }^{\circ} \mathrm{C}$. [X]-SIM: simulated value of the concentration for the compound "X"; [X]: experimental value for the concentration of the compound "X"; OLIG: oligomers and SUG: sugars

\section{Conclusions}

The study of the modelling of the hydrothermal fractionation of three different biomasses (holm oak, wheat straw and catalpa) in several packed bed reactors has been started in this work. The preliminary results showed a good agreement between the simulated and the experimental data. However, the discrepancies were quite important at the biggest reactor $(40.0 \mathrm{~L})$. Additionally, interesting results about the hydrothermal fractionation, like two different routes for the hemicellulose deacetylation, were also observed. However, this work must completed adjusting all the experimental data, making a comparison between them and performing a deep analysis of the parameters obtained during this optimisation. 
Appendix 2

\section{References}

A. Sluiter, B.H., R. Ruiz, C. Scarlata, J. Sluiter, D. Templeton. 2008. Determination of Sugars, Byproducts, and Degradation Products in Liquid Fraction Process Samples. Laboratory Analytical Procedure (LAP). Technical Report NREL/TP$510-42623$.

Cabeza, A., Sobrón, F., Yedro, F.M., García-Serna, J. 2015. Two-phase modelling and simulation of the hydrothermal fractionation of holm oak in a packed bed reactor with hot pressurized water. Chem. Eng. Sci., 138, 59-70.

Gallina, G., Alfageme, E.R., Biasi, P., García-Serna, J. 2018. Hydrothermal extraction of hemicellulose: from lab to pilot scale. Bioresour. Technol., 247, 980-991.

Kabyemela, B.M., Adschiri, T., Malaluan, R.M., Arai, K. 1999. Glucose and Fructose Decomposition in Subcritical and Supercritical Water: Detailed Reaction Pathway, Mechanisms, and Kinetics. Industrial \& Engineering Chemistry Research, 38(8), 2888-2895.

Lü, X., Saka, S. 2012. New insights on monosaccharides' isomerization, dehydration and fragmentation in hot-compressed water. The Journal of Supercritical Fluids, 61, 146-156.

Mok, W.S.L., Antal, M.J. 1992. Uncatalyzed solvolysis of whole biomass hemicellulose by hot compressed liquid water. Industrial \& Engineering Chemistry Research, 31(4), 1157-1161.

Pronyk, C., Mazza, G. 2010. Kinetic Modeling of Hemicellulose Hydrolysis from Triticale Straw in a Pressurized Low Polarity Water Flow-Through Reactor. Industrial \& Engineering Chemistry Research, 49(14), 6367-6375.

Reynolds, W., Baudron, V., Kirsch, C., Schmidt, L.M., Singer, H., Zenker, L., Zetzl, C., Smirnova, I. 2016a. Odor-Free Lignin from Lignocellulose by Means of High Pressure Unit Operations: Process Design, Assessment and Validation. Chem. Ing. Tech., 88(10), 1513-1517.

Reynolds, W., Baudron, V., Kirsch, C., Schmidt, L.M., Singer, H., Zenker, L., Zetzl, C., Smirnova, I. 2016b. Odor-Free Lignin from Lignocellulose by Means of High Pressure Unit Operations: Process Design, Assessment and Validation. Chemie Ingenieur Technik, 88(10), 1513-1517. 
Reynolds, W., Smirnova, I. 2017. Hydrothermal flow-through treatment of wheat straw: Coupled heat and mass transfer modeling with changing bed properties. The Journal of Supercritical Fluids.

\section{Table and Figure Captions}

Table 1. Set of experiments performed

Figure 1. Overall reaction pathway for hemicellulose hydrothermal fractionation. Note that $\mathrm{HC} 1$ refers to the hemicellulose directly deacetylated, $\mathrm{HC} 2$ to the hemicellulose that suffers the cleaving process and HC3 to the hemicellulose unaffected by the treatment. Similarly, B1 is the amount of inorganics extracted during the fractionation and B2 is the fraction that remains in the matrix. Blue rectangles are the compounds liquid phase, whereas the others refer to the substances in the solid.

Figure 2. Experimental and simulated oligomer (a), sugar (b), acetic acid (c) and pH (d) profiles for the wheat straw hydrothermal fractionation in the packed bed reactor of 3.0 $\mathrm{L}$ at $200^{\circ} \mathrm{C}$. [X]-SIM: simulated value of the concentration for the compound " $\mathrm{X}$ "; $[\mathrm{X}]$ : experimental value for the concentration of the compound "X"; OLIG: oligomers and SUG: sugars

Figure 3. Experimental and simulated oligomer (a), sugar (b), acetic acid (c) and pH (d) profiles for the holm oak hydrothermal fractionation in the packed bed reactor of $40.0 \mathrm{~L}$ at $200{ }^{\circ} \mathrm{C}$. [X]-SIM: simulated value of the concentration for the compound " $\mathrm{X}$ "; $[\mathrm{X}]$ : experimental value for the concentration of the compound "X"; OLIG: oligomers and SUG: sugars 
Appendix 3

\section{Appendix 3. Curriculum vitae}

\section{Álvaro Cabeza Sánchez}

Date of birth: 17/12/1989

Contact: +34 665610 169/alvaro.cabeza.sanchez@gmail.com

\section{EDUCATION}

2014-Currently: $\mathrm{PhD}$ in chemical and environmental engineering

2013-2014: Master in thermodynamics engineering of fluids at the University of Valladolid, Burgos and Rovira i Virgili

2007-2013: Master \& bachelor in chemical engineering at the University of Valladolid

\section{ADDITIONAL TRAINING}

Seminars and courses: Several courses about kinetics, reactor design, high pressure technology, industrial safety and green chemistry. It is worth mentioning two spring schools about European projects: SHYMAN and WINESENSE.

\section{LANGUAGES}

English: First certificate in English (2013) and Certificate in Advanced English (2016)

Spanish: mother language

\section{COMPUTER SKILLS}

Excel-Vba, Aspen and Java-Android: Medium-high level.

C++, Hysys, Matlab, EcoSim Pro, Simulink, LabView and SQL: Low level or just some basic knowledge.

\section{WORK EXPERIENCE}

2014-Nowadays: Pre-doctoral researcher inside several national research projects (references: CTQ2015-64892-R, ENE2012-33613 and CTQ2010-15475) at the university of Valladolid. My work there deals with the modeling of different green processes for the upgrading of biomass, like supercritical fluid extraction or hydrothermal fractionation. The validation of these models was also done using our own programs in $\mathrm{C}++$ and Excel-Vba. 
2012-2013: Internship of 6 months at the car factory of the enterprise Renault located in Villa Muriel del Cerrato, Palencia-Spain. During this period I did several analysis related to the energy consumption of the factory and technical assistance for the sales department.

\section{FURTHER INFORMATION}

Academic: Supervisor of one final degree project and a final master project about the development of Android applications related to chemical Engineering. Moreover, I have been involved in subjects about mass transfer and reactor design, giving theoretical lessons for $30 \mathrm{~h} / \mathrm{year}$ at the University of Valladolid.

International congresses: Oral presentations at the $2^{\text {nd }}$ Renewable Resources and Biorefineries (RRB10), 10 ${ }^{\text {th }}$ European Congress of Chemical Engineering (ECCE10), the $2^{\text {nd }}$ International Conference on Green Chemistry and Sustainable Engineering and the $10^{\text {th }}$ World Chemical Engineering Congress (WCCE10). Keynote at the $6^{\text {th }}$ congress on Green Process Engineering (GPE2018).

Awards: One award of the "Prometeo program-2016" given by the "Fundación General de la Universidad de Valladolid" for a suite of programs about chemical engineering. Furthermore, I obtained a grant from the Spanish Ministry of Education for my doctoral studies (FPU program).

\section{Foreign secondments:}

- 17 days at the "Technische Universitat" of Darmstadt, Germany

- 3 months at the technical University of Hamburg, Germany

\section{Research articles:}

- Cabeza, A., Sobrón, F., Yedro, F.M., García-Serna, J., 2015a. Autocatalytic kinetic model for thermogravimetric analysis and composition estimation of biomass and polymeric fractions. Fuel 148, 212-225.

- Cabeza, A., Sobrón, F., Yedro, F.M., García-Serna, J., 2015b. Two-phase modelling and simulation of the hydrothermal fractionation of holm oak in a packed bed reactor with hot pressurized water. Chemical Engineering Science $138,59-70$. 
- Cabeza, A., Piqueras, C.M., Sobrón, F., García-Serna, J., 2016a. Modeling of biomass fractionation in a lab-scale biorefinery: Solubilization of hemicellulose and cellulose from holm oak wood using subcritical water. Bioresource Technology 200, 90-102.

- Cabeza, A., Sobrón, F., García-Serna, J., Cocero, M.J., 2016b. Simulation of the supercritical $\mathrm{CO} 2$ extraction from natural matrices in packed bed columns: Userfriendly simulator tool using Excel. The Journal of Supercritical Fluids 116, 198208.

- Gallina, G., Cabeza, Á., Biasi, P., García-Serna, J., 2016. Optimal conditions for hemicelluloses extraction from Eucalyptus globulus wood: hydrothermal treatment in a semi-continuous reactor. Fuel Processing Technology 148, 350360.

- Cabeza, A., Santos, D.T., Meireles, M.A.A., Sobrón, F., Cocero Alonso, M.J., García-Serna, J., 2017. Pretreatment Effect on the Thermal Degradation of a Feedstock with Low Hemicellulose Content: Brazilian Ginseng. Energy \& Fuels $31,7123-7131$.

- Cocero, M.J., Cabeza, Á., Abad, N., Adamovic, T., Vaquerizo, L., Martínez, C.M., Pazo-Cepeda, M.V., 2017. Understanding biomass fractionation in subcritical \& supercritical water. The Journal of Supercritical Fluids.

- Gallina, G., Cabeza, Á., Grénman, H., Biasi, P., García-Serna, J., Salmi, T., 2017. Hemicellulose extraction by hot pressurized water pretreatment at $160^{\circ} \mathrm{C}$ for 10 different woods: Yield and molecular weight. The Journal of Supercritical Fluids.

- Piqueras, C.M., Cabeza, Á., Gallina, G., Cantero, D.A., García-Serna, J., Cocero, M.J., 2017. Online integrated fractionation-hydrolysis of lignocellulosic biomass using sub- and supercritical water. Chemical Engineering Journal 308, 110-125.

\section{Developed programs:}

- Android:

○ Energy properties calculator:

https://play.google.com/store/apps/details?id=com.pfc.ecuaciones

○ Chemical processes simulator:

https://play.google.com/store/apps/details?id=com.pfc.ecuaciones 
Appendix 3

- Excel- $\mathrm{C}++$ :

- Reactors (globalized and discretized) and adsorption column simulators.

All of them can be found at: http://hpp.uva.es/software/

Other skills:

Car driving license 
Appendix 3 